UNIVERSIDADE DE SÃO PAULO

FACULDADE DE FILOSOFIA, LETRAS E CIÊNCIAS HUMANAS DEPARTAMENTO DE TEORIA LITERÁRIA E LITERATURA COMPARADA

\title{
MODERNIZAÇÃO URBANA E EXPERIMENTAÇÃO FORMAL EM MANHATTAN TRANSFER, DE JOHN DOS PASSOS
}

\author{
Versão corrigida
}

Gabriela Siqueira Bitencourt

São Paulo 
UNIVERSIDADE DE SÃO PAULO

FACULDADE DE FILOSOFIA, LETRAS E CIÊNCIAS HUMANAS

DEPARTAMENTO DE TEORIA LITERÁRIA E LITERATURA COMPARADA

\title{
MODERNIZAÇÃO URBANA E EXPERIMENTAÇÃO FORMAL EM MANHATTAN TRANSFER, DE JOHN DOS PASSOS
}

Versão corrigida

\author{
Gabriela Siqueira Bitencourt
}

Tese apresentada ao Programa de PósGraduação em Teoria Literária e Literatura Comparada da Faculdade de Filosofia, Letras e Ciências Humanas da Universidade de São Paulo como requisito à obtenção do título de Doutora em Letras. Área de concentração: Teoria Literária e Literatura Comparada.

Orientador:

Prof. Dr. Jorge Mattos Brito de Almeida

De acordo:

São Paulo 
Autorizo a reprodução e divulgação total ou parcial deste trabalho, por qualquer meio convencional ou eletrônico, para fins de estudo e pesquisa, desde que citada a fonte.

Faculdade de Filosofia, Letras e Ciências Humanas da Universidade de São Paulo

Bitencourt, Gabriela Siqueira
B624m Modernização urbana e experimentação formal em "Manhattan Transfer", de John Dos Passos / Gabriela Siqueira Bitencourt ; orientador Jorge Mattos Brito de Almeida. - São Paulo, 2017. $228 \mathrm{f}$.

Tese (Doutorado) - Faculdade de Filosofia, Letras e Ciências Humanas da Universidade de São Paulo. Departamento de Teoria Literária e Literatura Comparada. Área de concentração: Teoria Literária e Literatura Comparada.

1. John Dos Passos. 2. Literatura norte-americana. 3. Montagem. 4. Teoria do romance. 5. Modernismo. I. Almeida, Jorge Mattos Brito de, (orient.) II. Título. 


\section{MODERNIZAÇÃO URBANA E EXPERIMENTAÇÃO FORMAL EM MANHATTAN TRANSFER, DE JOHN DOS PASSOS}

Gabriela Siqueira Bitencourt

Data da avaliação:

\section{Banca Examinadora}

Professor(a) Doutor(a)

Instituição

Professor(a) Doutor(a)

Instituição

Professor(a) Doutor(a)

Instituição

Professor(a) Doutor(a)

Instituição

Professor(a) Doutor(a)

Instituição 


\section{RESUMO}

BITENCOURT, Gabriela Siqueira. Modernização urbana e experimentação formal em Manhattan Transfer, de John Dos Passos. 2017. 228 f. Tese (Doutorado em Teoria Literária e Literatura Comparada) - Departamento de Teoria Literária e Literatura Comparada, Universidade de São Paulo, São Paulo, 2017.

Esta tese procura compreender de que modo a elaboração modernista da colagem e da montagem no romance Manhattan Transfer, de John Dos Passos, expressa e ilumina processos sociais e políticos de seu tempo. Publicada em 1925, essa obra é a primeira a investigar as transformações pelas quais passava Nova York, desde a virada do século XX até o início dos anos 1920, por meio de uma experimentação formal então única na literatura dos Estados Unidos. Além disso, defende-se a especificidade do romance de 1925, o qual não seria apenas uma preparação para a trilogia U.S.A. (1930-1936), mas configuraria um retrato singular do espírito de sua época. A sua forma se revelaria, então, não ruptura, mas continuidade do projeto realista de interpretação da sociedade. Propõe-se igualmente desenvolver uma discussão sobre a complexa interação entre modernismo e cultura periférica no começo dos anos 1920, com base em certa tradição da crítica literária brasileira (da qual os grandes nomes são Antonio Candido e Roberto Schwarz) atenta às relações contraditórias entre o processo de modernização e a forma literária. Nesse sentido, busca-se entender de que maneira a cultura dessa ex-colônia refletiu, pela obra de Dos Passos, sobre a sua própria condição periférica no período em que os Estados Unidos cresciam como potência econômica e militar. Por fim, procura-se mostrar como Manhattan Transfer foi capaz de formular literariamente e tornar visíveis os nexos - na época, nada evidentes - entre a urbanização de Nova York, a industrialização, a guerra e as novas tendências imperialistas que começavam a despontar.

Palavras-chave: John Dos Passos; Nova York; Montagem; Teoria do Romance; Modernismo; Literatura Norte-americana 


\begin{abstract}
BITENCOURT, Gabriela Siqueira. Urban modernization and formal experimentation in Manhattan Transfer, by John Dos Passos. 2017. 228 f. Dissertation (PhD) Departamento de Teoria Literária e Literatura Comparada, Universidade de São Paulo, São Paulo, 2017.
\end{abstract}

This thesis looks at how the modernist use of collage and montage in John Dos Passos' Manhattan Transfer expresses and sheds light upon the social and political processes of its time. Published in 1925, the book is the first to investigate the transformations undergoing New York from the turn of the $20^{\text {th }}$ Century to the beginning of the $1920 \mathrm{~s}$ by means of a formal experimentation hitherto unique in the literature of the United States. Moreover, this thesis argues for the specificity of the 1925 novel, which should not simply be understood as groundwork for the U.S.A trilogy (1930-1926), but rather as a singular depiction of the spirit of its time. Its form, accordingly, would prove to be not a break, but rather an unfolding of the realist project of interpretation of society. The complex interaction between modernism and peripheral culture in the early 1920s is likewise addressed here through a discussion based on a certain tradition of Brazilian literary criticism (featuring, among its major authors, Antonio Candido and Roberto Schwarz) particularly attentive to the contradictory relations between the process of modernization and the shifts in literary form. In this regard, the analysis carried out seeks to grasp in what way the culture of this former colony reflected, though the work of Dos Passos, on its own peripheral condition during the period marked by the rise of the United States as an economic and military power. Lastly, this thesis aims to show how Manhattan Transfer was able to formulate literarily and render visible the links - far from evident, at the time - connecting the urbanization of New York, the process of industrialization and the new imperialist tendencies that were beginning to emerge.

Key-words: John Dos Passos; New York; Montage; Theory of the Novel; Modernism; North American Literature 


\section{AGRADECIMENTOS}

Ao Professor Jorge de Almeida, a quem é difícil agradecer suficientemente por esses anos de uma orientação generosa, paciente e profundamente formadora. Agradeço por ajudar a descobrir os caminhos não mapeados dessa pesquisa e por um ensinamento contínuo que extrapola as margens do texto.

À Professora Ana Paula Pacheco pela leitura cuidadosa e interessada do relatório de qualificação. Ao Professor Marcos Soares por ter me ajudado a descobrir a literatura norte-americana, pelo debate sobre montagem, e por sempre estimular seus alunos à discussão política. Ao Professor Marcos Fabris, pelo curso sobre montagem nas artes plásticas, em que nos ensinou a ver. À Professora Sandra Vasconcelos e ao Professor Ross Forman pelos encontros e discussões sobre o romance e seus deslocamentos. À Professora Mary Ann Caws, por ter me recebido na City University of New York e ter possibilitado uma fase de pesquisa decisiva para essa tese. Ao Professor Ross Posnock, que me permitiu participar de seu seminário na Columbia University.

À John Dos Passos Society, por ter conseguido reunir tantos pesquisadores da obra de Dos Passos e criar um espaço importante para a troca de ideias. Agradeço principalmente ao Aaron Shaheen e Fredrik Tydal.

A todos os funcionários do Departamento de Teoria Literária e Literatura Comparada, sempre tão prestativos e comprometidos. Agradeço especialmente ao Luiz Mattos, que certamente fará muita falta.

Agradeço profundamente à minha família, cujo apoio nesses anos foi fundamental. Aos meus avós, Daisy, Celso e vô D'Ávila, e à memória de minha avó Teresinha e meu avô Hamilton. Aos meus queridos irmãos Andressa e Bruno, Caro e Victor, pela presença tranquila e confortante e pelos meus amados Léo, Elisa e Pituco - nosso futuro. À Aline e Márcia, e tudo que a música nos traz. À Isadora, pela amizade profunda e um companheirismo inabalável e terno. À Zizou e ao meu pai, Gabriel, pelo apoio tão amoroso e constante. Ao Roberto, sempre presente. À minha mãe, Milú, meu maior exemplo, a quem dedico este trabalho.

Aos meus queridos amigos que dividem a aventura e aprendizados de uma moradia compartilhada e feliz, agradeço pela amizade cotidiana: Caetano e Nina (irmãos que também fazem parte do parágrafo de cima), Arthur Lopes, Natasha, Ariel, Guilherme, Danilo, Artur (também pela versão do resumo) e Felipe (pela ajuda nas traduções do alemão). Também ao Franklin e ao Danilo Nunes.

Agradeço aos meus grandes amigos, cujas conversas e risadas são alento e dão força para continuar: Ton, Tiago, Virgínio, Paulinha, Pati Krüger, Vinicius Pastorelli, Paulo Yasha e Silvia. À Maíra, minha comadre querida. Às minhas amigas desde 47, Débora, Fernanda, Gabriela, Marina e Sofia. À Claudia, que me ajudou tantas vezes a pôr os pés no chão e ver mais longe. Ao César, mestre de estilo. Aos rosados Maria Carlotto e Ricardo Crissiuma, amigos até a última hora. E também aos queridos Caio Vasconcellos e à Rafaela, ao Bruno Carvalho, à Ana Carolina e ao Fábio De Maria, que me ajudou com referências importantes. Pelas viagens distantes, mas sempre compartilhadas, à Bruna e ao Edu. Pelas conversas sobre romance americano, ao Jorge Manzi. Ao Vinicius Domingues, pelos longos áudios e boas discussões. À 
Roberta, pelo interesse compartilhado em modernismo nos Estados Unidos, e por tantas ideias e textos trocados. À Paula Alves, pesquisadora de Georg Lukács, que me apresentou textos importantes, e ao Ernesto. Ao Leandro, parceiro de ideias, por seu espírito crítico e bom humor. À Eliane, revisora e grande amiga, cuja sensibilidade e talento me inspiram desde o começo da nossa graduação.

Durante meu estágio em Nova York, tive a chance de conviver e receber o apoio da Tatiana e do John, do Jeff, da Tássia e do Júlio, sem os quais minha estadia teria sido mais confusa e, ao mesmo tempo, tão mais tediosa. Esse período também me permitiu a feliz ocasião de reencontrar Caio Pedrosa, com quem descobri tantas afinidades.

Agradeço ao acaso (objetivo!) por ter tido a chance de conhecer os queridos Mariana Teixeira, Stéphane Pujol, Clara Castro, Pedro Fragelli e Michele - grandes amigos que Paris me deu e espero poder conservar por muitos anos. Seria impossível não mencionar e agradecer também aos queridos Blandine e Juan, Laura e Pedro, e aos amigos do MD18, em especial Maria Fernanda, Fred, Cecilia, Vanessa, Gabriel, Gabriel Zacarias, Gisela, Filipe e Tiaraju.

Esses agradecimentos, que não poderão contemplar todas as pessoas que de uma forma ou de outra contribuíram para esse doutorado, não seriam nem de longe completos se não falassem da importância da presença cotidiana de Daniel Garroux. Revisor e debatedor de todas as ideias aqui expressas, agradeço pelo companheirismo, carinho e pela cumplicidade de todos esses anos. 
Esta pesquisa contou com o auxílio fundamental da Coordenação de Aperfeiçoamento de Pessoal de Nível Superior (CAPES), por meio de uma bolsa de doutorado no Brasil e uma bolsa para a realização de um estágio no exterior (CAPES-PDSE). 


\section{SUMÁRIO}

Introdução..................................................................12

1. Longlegged Jack: antes do dilúvio.......................................27

1.1"I would give all the contemporary paintings in the U.S"...............37

1.2 Documentos da vida urbana........................................43

2. Sobre ilhas e pontes: colagem, montagem e experimentação.........................45

2.1 I wish I was a skyscraper: arquitetura da voz narrativa.........................46

2.2 The center of things: montagem como princípio estilístico...................55

2.3 A city of scrambled alphabets: colagem..............................61

2.4 Vidro e aço: reiterações e reaproveitamentos das colagens na estrutura narrativa.........................................................................85

3. Sonâmbulos: a insuficiência do herói............................................91

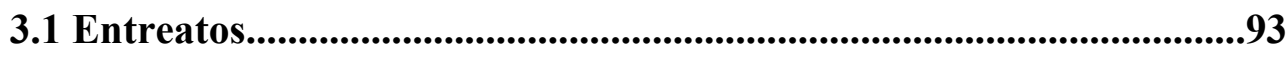

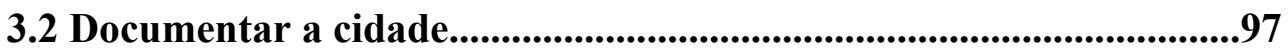

3.3 Ruídos.......................................................................................................................106

3.4 "Abaixo a flânerie!"”......................................................................................109

3.5 Máquinas de fantasmagorias....................................112

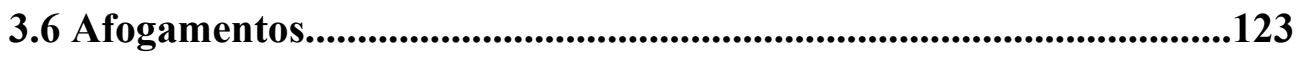

4. Da carroça ao metrô: a preponderância do espaço..................................130

4.1 Cartografias: Ellen........................................................................130

4.2 Cartografias: Bud, Jimmy e os limites da metrópole..............................136

4.3 Cartografias: Manhattan...................................................................141

4.4 "I remember when it was all meadows" "............................158

4.5 Cidade imperial..............................................................................................163

4.6 Uma máquina de guerra................................................................175

4.7 A natureza da máquina..............................................................................178

5. Constelação pré-fabricada: montagem como movimento...........................181 
5.1 Um lance de dados......................................................................184

5.2 A fellow traveler................................................................................................188

5.3 Natureza morta....................................................................................191

5.4 In Advance of the broken arm...............................................................195

5.5 À deriva......................................................................................197

Considerações finais..........................................................203

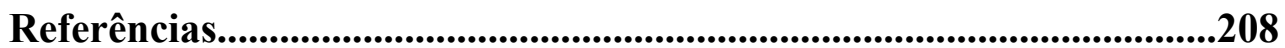




\section{INTRODUÇÃO}

\section{Novo Mundo}

Uma balsa repleta de anônimos se aproxima do porto de uma cidade: assim começa o romance de John Dos Passos, publicado em 1925, reencenando, em alguma medida, também a própria história da cidade de Nova York. Esses anônimos, como a maioria das personagens que acompanharemos ao longo das narrativas que compõem o livro, abandonaram o seu passado ao embarcar para o Novo Mundo. No romance de Dos Passos, a chegada dessa massa incógnita tem desdobramentos importantes: é como se cada corpo que deixa a balsa para pisar em terra firme rompesse o fio de sua vida pregressa. Na Manhattan histórica, as pessoas que desembarcam nas terras da ilha também deixaram o seu passado e, muitas vezes, trocaram de nome, embaladas por um sonho de recomeço e pela confiança de que chegavam a um local onde, para o homem comum, haveria uma chance real de prosperidade. Talvez nenhuma cidade tenha construído e encarnado de forma tão poderosa o sonho do Novo Mundo como Nova York, esse antigo entreposto comercial da Companhia das Índias Ocidentais que se tornaria, por necessidade de sua posição mercantil, uma região de relativa tolerância religiosa (ao menos quando a comparamos a outros assentamentos coloniais) e mistura de origens.

A importância de Manhattan Transfer não se restringe ao fato de ter sido considerado por muitos críticos o primeiro romance modernista estadunidense ${ }^{1}$. Tratase de uma grande obra devido não apenas à sua capacidade de representar a realidade de uma metrópole internacional dos anos 1920 mas também de descobrir e de tornar visíveis as articulações ocultas entre aspectos aparentemente desconexos da realidade, como a modernização urbana, a guerra, a indústria da propaganda, o fordismo e o cotidiano mais banal de um habitante qualquer da metrópole. Acionando a maquinaria de forças e processos sociais a partir de uma forma literária que radicaliza uma série de convenções narrativas, o romance de Dos Passos ajuda a revelar, de forma singular, particularidades e vínculos dessa nova experiência social.

\footnotetext{
${ }^{1}$ HOOK, Andrew; SEED, David. John Dos Passos. In: SEED, David (Org.). A company to twentiethcentury United States fiction. Chischester: Wiley-Blackwell, 2010, p. 252.
} 


\section{Velhas formas}

Na década de 1920, Alfred Döblin publicou o seu romance mais importante, Berlin Alexaderplatz, no qual a experimentação técnica também está associada à representação de uma experiência de modernização urbana muito recente. Döblin, escrevendo desde a virada do século, teceu uma profunda reflexão sobre o alcance e as possibilidades da produção em prosa de sua época - reflexão que se insere em um amplo debate sobre o romance e ganhou extensão principalmente na Alemanha. Quando usou, em 1922, o termo "crise do romance", Otto Flake tinha como objetivo encontrar uma formulação conceitual para uma espécie de percepção difundida de um desencontro entre um modelo tradicional da ficção romanesca e um tipo de experiência moderna (e o adjetivo pode indicar diferentes periodizações, dependendo do autor) que exigia, para a sua representação, uma nova forma ${ }^{2}$. A formulação é genérica, como frequentemente ocorre quando se procura falar de toda a produção de uma época ou ao se sugerir tradições literárias homogêneas. Tratava-se, contudo, de uma percepção compartilhada por diferentes artistas de seu tempo, embora abordada de maneiras diversas, e o termo foi empregado por uma série de romancistas e críticos ao longo dos anos 1920 e $1930^{3}$. Alfred Döblin e Walter Benjamin, entre outros, discutiram os limites da forma do romance especificamente no período e problematizaram o conceito de "crise". Nesse sentido, foi para compreender como se articulavam esses debates literários acerca do "métier do antigo romance" ${ }^{4}$ e a experiência história específica que desenvolvi a minha pesquisa de mestrado sobre Berlin Alexanderplatz, de Alfred Döblin.

Se a pergunta inicial relacionava o conceito de crise e a formulação desse romance em particular, a partir da análise dessa obra de 1929 o quadro de relações ganhou outros vetores. Assim, procurei discutir, em primeiro lugar, o modo como

\footnotetext{
2 "Para Flake, como já foi sugerido, as causas residiam no fato de que as relações sociais haviam deslanchado de tal modo que elas não podiam nem ser refletidas adequadamente na forma tradicional do romance, nem convertidas em uma nova ordem social.". [Tradução nossa a partir do original: "Für Flake lagen die Ursachen, wie schon angedeutet, darin, dass die Gesellschaftlichen Verhältnisse so sehr in Fluss geraten waren, dass sie in der traditionellen Romanform weder angemessen reflektiert noch in einen neuen Ordningsentwurf überführt werden konnten".] KIESEL, Helmut. Geschichte der literarische Moderne. Sprache, Ästhetik, Dichtung im zwanzigsten Jahrhundert. Munique: C.H. Beck, 2004 , p. 316.

${ }^{3}$ KIESEL, Helmuth. Geschichte der literarische Moderne, cit., p. 316.

${ }^{4}$ DÖBLIN, Alfred. Crise do romance? In: GREGORY, João Alceu. O romance O tigre azul como forma estética do pensamento histórico de Alfred Döblin. 2003. Tese (Doutorado em Literatura Alemã) - Faculdade de Filosofia, Letras e Ciências Humanas da Universidade de São Paulo, São Paulo, 2003, p. 367 .
} 
foram utilizados, na estrutura da obra, procedimentos experimentais associados aos movimentos modernistas do início do século XX. Especificamente, debrucei-me sobre o uso radical dos expedientes literários de montagem e colagem no romance e sobre os aspectos que o aproximavam e afastavam da Nova Objetividade, movimento ao qual é frequentemente associado. Interessava-me pesquisar, sobretudo, quais nexos existiam entre o uso desses procedimentos e a aspiração de representar um fenômeno urbano relativamente recente no contexto alemão - a metrópole industrial em que Berlim se transformava em meados de 1920. Valendo-se também de certas convenções próprias à tradição do gênero, Alfred Döblin foi capaz de formular uma inesperada e complexa configuração desse romance, convencionalmente associado à representação de um indivíduo burguês - ou de alguns indivíduos -, figura da qual depende a articulação das partes. O embate com esses pressupostos, latentes e problematizados no romance de Döblin, era constitutivo para a representação formal dos nexos da experiência dessa estrutura coletiva - a metrópole -, cuja novidade parecia residir justamente na impossibilidade de apreensão e codificação do todo a partir de modelos convencionais, centrados em um núcleo biográfico que organizaria as partes e as relações intersubjetivas.

Berlin Alexanderplatz foi publicado, por um acaso que ajuda a iluminar questões basilares desse romance, poucos meses antes da quebra da bolsa de valores de Nova York, em 1929. A moldura cronológica de seu enredo - e também de sua escrita - situa-o em uma fase de aparente progresso social e estabilidade da economia alemã, cujos limites e problemas seriam rapidamente revelados pelo crash da bolsa ${ }^{5}$. A importante obra de Döblin, anterior à trágica quinta-feira do fim de outubro de 1929, já traduzia na construção de suas tensões internas, por meio de sua fatura dissonante, os impasses, nem sempre subterrâneos e reprimidos, que marcaram o desenvolvimento econômico e os movimentos artísticos da República de Weimar. A força desse romance reside em sua fatura difícil, que não permite apaziguamento das contradições. Embora, ao fim da obra, o mutilado Franz Biberkopf - esse "gigante infantil e desamparado" - feche-se e proteja-se no cubículo em que trabalha contra o

\footnotetext{
${ }^{5}$ KRACAUER, Siegfried. From Caligari to Hitler. A psychological history of the German film. Nova Jersey: Princeton University Press, 1966, p. 131.
} 
"remoinho da cidade", o conflito que anima todo o romance persiste, sem promessa de conciliação.

\section{O remoinho das cidades: de Berlim à América}

Publicada quatro anos antes de Berlin Alexanderplatz, Manhattan Transfer é uma obra comumente aproximada ao livro de Döblin, e a sua influência sobre o escritor alemão é tema corriqueiramente debatido. Para além da discussão de influências, o meu interesse pela obra de John Dos Passos surgiu na medida em que o romance se debruça sobre problemas semelhantes, articulando as convenções do gênero aos usos de expedientes artísticos modernistas em um período de intenso crescimento urbano.

Nos Estados Unidos, contudo, se havia alguma "crise do romance", aqueles que participavam do debate pareciam muito mais aflitos com o fato de, aparentemente, não existir ainda uma tradição nacional do romance ou, antes, uma tradição literária. Basta folhear páginas de revistas como a The Seven Arts, em que os autores da época expõem as suas impressões, ou ler textos avulsos e cartas de escritores como Dos Passos e Ezra Pound, para notar como pairava por todo o meio artístico essa sensação de que os Estados Unidos permaneciam uma periferia cultural ainda dependente da produção continental': "Nós não temos uma tradição para continuar; nós não temos uma escola de estilo para desenvolver. O que pedimos do autor é apenas autoexpressão sem consideração pelos padrões das revistas atuais". ${ }^{8}$

Se os escritores europeus sentiam a necessidade de inventar uma nova forma, os estadunidenses ansiavam por conseguir, finalmente, estabelecer uma tradição

\footnotetext{
${ }^{6}$ ROSENFELD, Anatol. A confusão de Babel: Alfred Döblin. In: Letras germânicas. São Paulo: Perspectiva, 1992, p. 168.

${ }^{7}$ Mesmo no ano de 1936, Dos Passos ainda avaliava que, em termos de artes plásticas, os Estados Unidos haviam sido e continuavam dependentes de estilos estrangeiros: "American art (always excepting Winslow Homer) has been first English provincial, then French impressionist provincial, school of Paris provincial and now it leans towards becoming Mexican provincial. We haven't yet done anything important in that direction". DOS PASSOS, John. Grosz Comes to America (1936). In: PIZER, Donald (Org.). John Dos Passos: the major nonfictional prose. Detroit: Wayne State University Press, 1988, p. 175.

${ }^{8}$ Tradução nossa do original: "We have no tradition to continue; we have no school of style to build up. What we ask of the writer is simply self-expression without regard to current magazine standards". OPPENHEIM, James. Editorial. The Seven Arts, New York: The Seven Arts Publishing Co., v. 1, n. 1, p. $53,1916$.
} 
intelectual e artística de peso e representatividade nacional ${ }^{9}$. Dito desse modo, esse aparente desprezo dos artistas da época pela maior parte da literatura estadunidense produzida pelo menos no século XIX pode suscitar estranhamento. Contudo, era essa a sensação que movia muitos autores, com uma carga de missão construtiva que conduzia boa parte dos debates nas pequenas revistas da época e a produção literária dos escritores das primeiras três décadas do século XX.

É por essa especificidade, digamos, periférica, que o tão intenso debate entre realismo e modernismo, o qual animava vários círculos europeus, não é feito nos mesmos termos nos Estados Unidos ${ }^{10}$. Some-se a isso o fato de que o desenvolvimento da técnica na produção industrial e cultural, e a apropriação de produtos desse processo pela arte dita "séria" possuíam nos Estados Unidos um caráter singular. Para compreender em que consiste essa singularidade, basta notar como uma das grandes queixas dos artistas nas décadas que antecederam o modernismo dos anos 1920 era justamente a de que a "única missão" do país "no universo, seu destino, sua finalidade" seria criar um "maquinário para aliviar o fardo do homem" - na divertida formulação de Theodore Dreiser ${ }^{11}$. Muitos movimentos artísticos das primeiras décadas do século XX procuraram recuperar dados da cultura popular por meio de técnicas artísticas novas. O caso do movimento modernista no Brasil, por exemplo, é iluminador se pensarmos como a cultura popular, em associação a outros "recalques históricos, sociais, étnicos"12, foi revalorizada e tornou-se parte de um movimento de construção do próprio País ${ }^{13}$. A diferença reside

\footnotetext{
${ }^{9}$ Em uma entrevista de 1968, Frank Gado, professor da Union College, cita a preocupação constante, após a Guerra Civil, de se criar The Great American Novel, uma épica "americana", e questiona se a geração de Dos Passos tinha a consciência de que estava dedicada a criar um panorama capaz de "capturar a essência da nação", ao que Dos Passos responde afirmativamente. DOS PASSOS, John. An interview with John Dos Passos (1968). In: PIZER, Donald (Org.). John Dos Passos: the major nonfictional prose. Detroit: Wayne State University Press, 1988, p. 287.

${ }^{10}$ No plano mais restrito, vale mencionar que Dos Passos sempre mostrou certa aversão a classificações: "The period immediately before and after World War I had been a period of experimentation both in Europe and America. The Europeans have a sense of order and hierarchy that makes them love labels as much as the typical American tends to distrust them. Maybe trying to escape classification is one of our national vices”. DOS PASSOS, John. Contemporary Chronicles (1961). In: PIZER, Donald (Org.). John Dos Passos: the major nonfictional prose. Detroit: Wayne State University Press, 1988, p. 238.

${ }^{11}$ DREISER, Theodor. Life, Art and America. The Seven Arts, New York: The Seven Arts Publishing Co., v. 1, n. 4, p. 370, 1917.

${ }^{12}$ CANDIDO, Antonio. Literatura e cultura de 1900 e 1945. In: Literatura e sociedade. São Paulo: Ed. Nacional, 1965, p. 126.

13 "Finalmente, não se ignora o papel que a arte primitiva, o folclore, a etnografia tiveram na definição das estéticas modernas, muito atentas aos elementos arcaicos e populares comprimidos pelo academismo. Ora, no Brasil as culturas primitivas se misturam à vida quotidiana ou são reminiscências ainda vivas de um passado recente. As terríveis ousadias de um Picasso, um Brancusi, um Max Jacob,
} 
principalmente em que, nos Estados Unidos, muitos desses elementos "recalcados", que passaram a ser revalorizados durante o período do modernismo, eram nada primitivos ou folclóricos, mas principalmente aqueles ligados aos processos de industrialização: a música de Tin Pan Alley, os quadrinhos de jornal, os arranha-céus, a propaganda. Portanto, o momento em que as artes começam a valorizar e a incorporar elementos da indústria cultural e da própria produção industrial representa uma reavaliação da cultura e do seu papel nacional no cenário mundial. Trata-se, segundo Ann Douglas, do período em que os Estados Unidos conseguiram atingir a sua fase pós-colonial ${ }^{14}$.

Assim, Manhattan Transfer é o primeiro romance nos Estados Unidos a se apropriar desses elementos a partir de uma construção narrativa inovadora. Em sua estrutura reverberam os processos sociais de seu tempo, principalmente os frutos do progresso técnico e do impacto da mecanização - algo que pode ser observado já nos primeiros escritos não ficcionais de Dos Passos. Quando, no início da década de 1920, após algumas intermitentes temporadas no exterior, o autor retorna ao seu país natal, em meio a esse espírito de descoberta tão vivaz, ele observa Nova York com olhar renovado: "Era maravilhosa. Era horrenda. Tinha de ser descrita"15. Contudo, o autor faz mais do que "descrever" essa cidade. Nesse movimento de reapropriação e reavaliação, ele consegue, por meio de uma invenção literária alimentada pelas transformações de sua época, produzir uma forma capaz de expressar, de modo crítico, os aspectos mais profundos desse mundo que ele conhecia e que pretendia representar.

Embora Nova York já fosse uma cidade em crescimento acelerado desde pelo menos a metade do século XIX, é depois da Guerra Civil, com os grandes êxodos das áreas rurais e o crescimento da população urbana ${ }^{16}$, que os "problemas da cidade se tornaram os grandes problemas da nação"17. O período englobado por Manhattan Transfer (de mais ou menos 1890 a 1920) apresenta um processo de rápida implementação de sistemas de transporte, comunicação e infraestrutura que alteraram,

um Tristan Tzara eram, no fundo, mais coerentes com a nossa herança cultural do que com a deles". CANDIDO, Antonio. Literatura e cultura de 1900 e 1945, cit., p. 127.

${ }^{14}$ DOUGLAS, Ann. Terrible honesty. Mongrel Manhattan in the 1920s. New York: Farrar, Straus and Giroux, 1995, p. 4.

${ }^{15}$ Tradução nossa do original: "It was marvelous. It was hideous. It had to be described". DOS PASSOS, John. What Makes a Novelist (1968). In: PIZER, Donald (Org.). John Dos Passos: the major nonfictional prose. Detroit: Wayne State University Press, 1988, p. 271.

${ }^{16} \mathrm{O}$ papel da imigração estrangeira é fundamental, mas já vinha ocorrendo de forma massiva desde pouco antes de 1850 .

${ }^{17}$ WHITE, Lucia; WHITE, Morton. The intellectual versus the city. From Thomas Jefferson to Frank Lloyd Wright. Cambridge; Massachusetts: Harvard University Press, 1962, p. 54. 
de forma acelerada, a própria relação com o espaço metropolitano: “A cidade se tornou o lar do trilho de trem elevado, dos bondes, bondes a cabo, do metrô, do apartamento, telefone, arranha-céu, e da gigantesca estação de trem"18.

Em uma época em que a própria cidade começa a ser equiparada a uma máquina ${ }^{19}$ e termos como "eficiência" e "produtividade" passam a integrar o discurso cotidiano, esses anos pareciam garantir que as promessas de plenitude social alimentadas pelo progresso técnico estavam em vias de se cumprir. Sem dúvida, como argumenta Howard Zinn, a verdadeira realização do ideal de enriquecimento e sucesso estava reservada apenas a uma faixa social muito estreita. Enquanto mais de $46 \%$ das famílias da nação viviam com menos de mil dólares por mês e dois milhões de pessoas habitavam os cortiços miseráveis de Manhattan, apenas cinco por cento concentravam um terço de toda fortuna produzida nos Estados Unidos. Havia, de todo modo, um progresso econômico comedido, mas real para a classe média. A taxa de desemprego, por exemplo, baixou pela metade entre 1921 e $1927^{20}$, um em cada três cidadãos "possuía rádio e gravador e três em cada quatro frequentavam o cinema ao menos uma vez por semana"21.

A convergência entre otimismo econômico - em um momento de valorização cultural da produção nacional - e crença no progresso técnico fazem parte da atmosfera de todo o período que se estende desde o fim da Guerra Civil até o crash da bolsa de valores. Essa sensação de que o desenvolvimento técnico do país era, por um lado, quase parte da essência nacional e, por outro, um impulso muito particular que o transformava em uma nação singular é recorrente e permeia vários discursos. A revista Harper's Weekly, por exemplo, publicou um editorial em 1912 alegando que havia um grande "movimento em favor da eficiência" que poderia franquear as portas de uma "nova era na vida nacional"22. Esse otimismo, propagado e reforçado pelas mídias, foi intensificado pela saída vitoriosa dos Estados Unidos da Primeira Guerra

\footnotetext{
${ }^{18}$ Tradução nossa do original: "The city became the home of the elevated railroad, the trolley-car, the cable car, the subway, the apartment house, the telephone, the skyscraper, and the massive railroad station". WHITE, Lucia; WHITE, Morton. The intellectual versus the city, cit., p. 54.

${ }^{19}$ Nas palavras de Henry James, "colossal set of clockworks, some steel-souled machine-room of brandished arms and hammering fists". JAMES, Henry. Collected travel writings: Great Britain and America. New York: Library of America, 1993, p. 418.

${ }^{20}$ ZINN, Howard. A people's history of the United States: 1492-present. Londres, New York: Routledge, 2003, p. 907-908.

${ }^{21}$ DOUGLAS, Ann. Terrible honesty, cit., p. 20.

${ }^{22}$ TICHI, Cecelia. Shifting gears. Technology, literature, culture in modernist America. Chapel Hill; London: The University of North Carolina Press, 1987, p. 75.
} 
Mundial $^{23}$. Além da importância simbólica dessa vitória, o país se tornou a maior nação credora do mundo ${ }^{24}$ e houve uma ampliação da produção interna, também decorrente da participação na guerra. A confluência desses aspectos fez com que o país se tornasse uma das nações mais influentes no cenário do capitalismo internacional e que as discussões sobre o seu papel entre as grandes potências internacionais ganhassem intensidade e urgência.

Embora a quebra da bolsa de valores ainda não estivesse no horizonte visível durante esses "anos de ouro", as condições que levaram a ela - essa "morte espetacular", nas palavras de Fitzgerald - já estavam latentes nos anos que precederam o fatídico 1929. Sob o lustre da era do jazz, havia pobreza, lutas operárias e repressão. Se a década de 1920 realmente parecia um "tempo emprestado",25, a relação entre otimismo, progresso técnico e mecanização de todos os modos de produção, bem como entre imperialismo econômico e prognósticos sombrios, é colocada em movimento pela forma experimental do romance de Dos Passos.

\section{O ritmo da metrópole}

Esta tese parte da constatação de que o experimentalismo estético que caracteriza o romance Manhattan Transfer é uma resposta às condições sociais do novo estágio de desenvolvimento em que se encontrava Nova York, além de configurar uma expressão dos problemas que isso impunha à forma literária. As tensões entre o otimismo latente da época e os índices do limite de sua expansão, bem como a importância oculta da guerra e o desenvolvimento das forças produtivas em escala fordista, são aspectos que muitas vezes não aparecem tematizados, mas estão dispostos em uma estrutura de constelação cujo movimento tem duas grandes funções. A primeira diz respeito aos vínculos instáveis entre esses temas da época que determinam o modo como o romance representa a experiência subjetiva (múltiplas tramas desconexas). Já a segunda sugere nexos em meio à multiplicidade heterogênea do texto e das personagens.

Um dos pontos que gostaria de ressaltar está relacionado ao fato de esse romance de Dos Passos ser, corriqueiramente, visto como uma preparação para a

\footnotetext{
${ }^{23}$ DOUGLAS, Ann. Terrible honesty, cit., p. 179.

${ }^{24}$ POLYCHRONIOU, Chronis. Rise and Fall of US Imperialism. Economic and Political Weekly, v. 30, n. 30, p. PE-56, 1995. Disponível em: <www.jstor.org/stable/4403046 >. Acesso em: 11 set. 2016.

${ }^{25}$ FITZGERALD, F. Scott. “Ecos da Era do Jazz”. Crack-up. Porto Alegre: L\&PM, 2007, p. 22.
} 
escrita de U.S.A., a grande trilogia que alçou Dos Passos ao patamar de maior representante de sua geração. Como Andrew Hook e David Seed notaram, assumir que o romance de 1925 representa apenas uma "preparação" para a trilogia reduz a "escala da ambição do autor" e obscurece uma série de diferenças formais entre os dois romances $^{26}$. Além disso, acredito que há uma especificidade importante em Manhattan Transfer, a qual consiste no fato de a obra ter sido escrita em meio ao movimento modernista anterior à quebra da bolsa de valores em 1929. Toda a sua produção foi instigada pela tensão entre o já comentado otimismo de seu período histórico e um confronto político e cultural em relação à ideologia industrial hegemônica.

Quatro anos antes do crash, a grande depressão nos Estados Unidos ainda não podia ser tematizada pelo romance, mas os limites da ideologia da época transparecem na tensão entre as partes, a qual exploraremos mais adiante. Essa tensão pode ser descrita como um otimismo que transparece no discurso enunciado e um pessimismo que se move por trás da maquinaria da cidade. No caso de Nova York, o que a matriz do "sonho americano" ao alcance de todos esconde é que, mesmo no centro do capitalismo, o progresso também pressupõe o subdesenvolvimento de outras regiões, a opressão do mundo trabalho, a miséria. O clima de entusiasmo em relação às possibilidades abertas pelo capitalismo comparece em Manhattan Transfer em várias cenas, sem que isso implique a ratificação dessa euforia na fatura da obra - pelo contrário, como se verá em momento oportuno desta tese. Na ficção de Dos Passos, para além da representação temática (expressa nas inúmeras promessas de realização pessoal vinculadas ao desenvolvimento urbano e econômico de Nova York), a euforia é formalmente representada e problematizada. Na elaboração da narrativa, o clima dos anos 1920 se traduz, parcialmente, em uma atmosfera de uniformidade que impossibilita, no espaço dessa metrópole cacofônica, a existência de elementos que lhes sejam antitéticos - aspecto totalizante e totalitário que terá implicações temáticas (nas tramas) e formais (na composição das personagens).

Se o horizonte da obra parece ser a crise de 1929, talvez a sua outra baliza histórica seja a Primeira Guerra Mundial - e, por consequência, a nova fase do imperialismo estadunidense. Dos Passos serviu na frente de batalha como motorista de

\footnotetext{
${ }^{26}$ HOOK, Andrew; SEED, David. John Dos Passos, cit., p. 253.
} 
ambulância e dedicou-se a expor esse "enorme absurdo"27, a vida dos combatentes durante a guerra, até o início de 1920, quando publicou o romance Three soldiers. Com a vitória sobre a Alemanha, o país poderia finalmente colocar em curso o que, como Dos Passos nota ironicamente em um texto de 1915, seria o seu grande destino: conquistar o mundo por meio de seus "métodos comerciais" 28 .

Essas duas referências do romance, a Primeira Guerra e o crash de 1929, podem ajudar-nos a interpretar de que modo alguns dos principais temas desse livro são expressos não apenas no conteúdo enunciado mas também na estrutura narrativa e em certas técnicas mobilizadas pelo autor. Manhattan Transfer conseguiu revelar relações de força da época que pareciam resistentes à representação artística, refratárias à tentativa de fixá-las na forma convencional do romance realista (e naturalista) - nos Estados Unidos, a tradição mais forte da geração anterior à de Dos Passos. Em vez de implicar uma ruptura com essa tradição, a forma experimental de Dos Passos talvez seja melhor compreendida como uma reformulação do projeto realista nacional no sentido de manter a ambição investigativa. Esse processo de reformulação expõe também, formalmente, os conflitos internos gerados pelo confronto com essa matéria histórica. Em vez de ocultamento, a obra de Dos Passos propõe uma ambígua exposição do artifício, na medida em que alterna a sensação de transparência dos fatos e a manifestação do caráter montado, armado da obra. São essas tensões que conferem ao romance o seu aspecto mais radical e que fizeram com que fosse alvo de um grande debate estético (compreendidas aqui também as questões políticas) desde o ano de sua publicação.

A história da recepção da obra de Dos Passos, todavia, é descontínua e irregular. Embora os seus primeiros romances não tenham sido muito divulgados, após Manhattan Transfer o seu nome passa a ser mais conhecido entre intelectuais, romancistas e pela crítica. É apenas, contudo, a partir da publicação do primeiro volume de U.S.A. que ele se torna um artista realmente discutido e renomado fora de seu país, e é com 1919, o segundo volume da trilogia, que a sua importância se consagra.

\footnotetext{
27 "Utter damn nonsense". DOS PASSOS, John. Letter to Rumsey Marvin (Aug. 1917). In: The fourteenth chronicle: letters and diaries of John Dos Passos. Edited by Townsend Ludington. Boston: Gambit, 1973, p. 92.

${ }^{28}$ DOS PASSOS, John. The Evangelist and the Volcano. In: PIZER, Donald (Org.). John Dos Passos: the major nonfictional prose. Detroit: Wayne State University Press, 1988, p. 25.
} 
Durante as décadas de 1910 e 1920, a inclinação política de Dos Passos tendeu cada vez mais à esquerda. Apesar de nunca ter decidido se filiar ao Partido Comunista, o autor teve uma atuação muito intensa no teatro, com o grupo New Playwrights Theatre, e no campo jornalístico, como editor e escritor para a New Masses, uma espécie de continuação do periódico Masses, extinto por Woodrow Wilson durante a Primeira Guerra Mundial. Como jornalista, acompanhou o polêmico caso SaccoVanzetti. Na década de 1930, porém, com todas as contradições da Frente Popular nos Estados Unidos, a Guerra Civil espanhola e a divulgação do início das perseguições e do Grande Expurgo de Moscou, o escritor afastou-se progressivamente da esquerda até o distanciamento completo. A sua trajetória política afetou a recepção de sua obra, que, após 1940, tornou-se muito enfraquecida. Dos Passos, que havia sido chamado por Sartre de o "grande escritor de sua geração", terminou a sua carreira pouco valorizado.

No Brasil, a sua recepção se deu de modo muito inconstante. Por volta dos anos 1930, quando já tinha publicado as suas grandes obras, temos apenas o relato de Oswald de Andrade que rebate uma crítica de Tristão de Ataíde, segundo a qual o seu romance seria uma cópia do estilo de Dos Passos ${ }^{29}$. Em 1970, em seu texto sobre a obra de Oswald de Andrade, o crítico Antonio Candido retornou brevemente a essa comparação para apontar as especificidades e diferenças entre a trilogia U.S.A. e o projeto desenvolvido nas obras do escritor brasileiro ${ }^{30}$. Apesar de Candido destacar a importância do romance estadunidense, quase nada foi escrito sobre Dos Passos nos anos que se seguiram. As viagens do autor ao Brasil também deram ensejo a uma série de pequenos artigos nos jornais, mas, à exceção de Três soldados, traduzido em 1932 pela editora Guaira, as suas demais obras literárias passaram largamente despercebidas.

$\mathrm{Na}$ esfera acadêmica, além de resenhas e textos curtos, nada havia sido escrito sobre Dos Passos até recentemente. Em 2015, foram defendidas duas dissertações de mestrado. A primeira delas é de Aline Shaaban Soler, um estudo sobre Manhattan

\footnotetext{
29 "Isso tudo para lhe assegurar que a minha antropofagia pode 'coincidir' com diversas expressões da corrente americana [John Dos Passos e Waldo Frank], inevitável, irremediável, inadiável, que já pus na panela e há de comer o cristianismo colonial que você erradamente declara que é a nossa infância verdadeira.” ANDRADE, Oswald. Imprecação a Tristão de Ataíde. In: . Estética e política. São Paulo: Globo, 2011, p. 58.

30 "A visão de uma larga realidade social pode ser aprendida melhor através da multiplicidade de cenas e tipos apresentados de maneira descontínua, numa espécie de amostragem por justaposição que revela o todo com amplitude e variedade maiores do que seria possível a uma narrativa unitária. John Dos Passos esfarinhou a vida americana nos múltiplos níveis de enfoque da trilogia U.S.A., e o resultado foi tecnicamente bom"." CANDIDO, Antonio. Digressão sentimental sobre Oswald de Andrade. In: . Vários escritos. São Paulo: Duas Cidades, 2004, p. 55.
} 
Transfer, intitulado A metrópole e a prosa cinematográfica no modernismo estadunidense: uma abordagem de Manhattan Transfer de John Dos Passos. Nela, a pesquisadora aborda a relação entre modernismo e realismo, bem como entre a experimentação técnica do romance e a que se verifica no cinema, além de analisar a representação da metrópole no romance. A segunda é de Gabriel Jorge Barbosa dos Santos, Na trilha de Dos Passos, que infelizmente não tive a oportunidade de ler, pois não se encontra disponível no banco de teses. Em andamento, há a pesquisa de Lauro Iglesias Quadrado, The poetics of noise, sobre a relação de Manhattan Transfer com os novos paradigmas acústicos, em que se discute também a força das experiências modernas (da modernidade e modernistas) com diferentes sonoridades. Completando o quadro nacional, é interessante lembrar a publicação recente da tradução da trilogia U.S.A. pela editora Benvirá em 2012. Há, pode-se notar, um interesse renovado pela obra do autor - interesse que parecia inexistente no Brasil e letárgico mesmo nos Estados Unidos. Esse curioso e simultâneo despertar de atenção também se revela na organização, pela John Dos Passos Society, dos dois primeiros encontros internacionais sobre Dos Passos, o primeiro em Chattanooga, no estado do Tennessee, nos Estados Unidos (2014), e o segundo em Madri, na Espanha (2016).

O projeto deste doutorado nasceu em 2012 do desejo de compreender como as questões que haviam animado nossa pesquisa de mestrado - principalmente a relação entre modernismo estético no romance e modernização urbana - arquitetavam-se no solo do Novo Mundo, notadamente, no Brasil e nos Estados Unidos, países de tradição literária mais recente e marcados por um passado colonial. A ideia inicial era realizar um estudo comparado entre Manhattan Transfer e Serafim Ponte Grande, de Oswald de Andrade que, embora tenha sido publicado apenas na década de 1930, foi escrito antes da quebra da Bolsa de Valores. Nos romances de Oswald de Andrade e Dos Passos, a experiência da modernização certamente está implicada na forma da narrativa. Ambos figuram entre os experimentos mais radicais de suas respectivas tradições literárias, com a assimilação, de forma inovadora, de procedimentos modernistas. Eles questionam também quase todos os elementos narrativos tradicionais, usam a descontinuidade do fragmento, abusam de todos os registros e embaralham as noções de enredo linear. Interessava, contudo, discutir, além das similaridades, de que modo as diferenças dos dois romances poderiam iluminar questões acerca do processo de modernização dessas duas metrópoles do século XX. Conforme a pesquisa caminhava durante um estágio de doutorado-sanduíche na City University of New York, o estudo 
sobre o contexto estadunidense exigiu um aprofundamento que demandava mais tempo do que uma tese em literatura comparada poderia oferecer e, por isso, foi necessário restringir o foco de análise a um único romance, Manhattan Transfer. As questões levantadas pelo estudo comparado continuaram, entretanto, norteando a pesquisa sobre o romance de Dos Passos com vistas a um futuro desenvolvimento das relações entre literatura estadunidense e brasileira.

Esta pesquisa não pretende, todavia, fazer uma análise exaustiva de toda a estrutura de Manhattan Transfer - projeto que já foi levado a cabo de forma muito consistente por pesquisadores como Jean-Pierre Morel $^{31}$. Também não se trata de desenvolver uma discussão sobre as questões entre o romance e o cinema, pois essa abordagem já foi realizada de forma criteriosa por inúmeros estudiosos da obra de Dos Passos, recentemente por David Seed, em Cinematic fictions, e, no Brasil, na dissertação de Soler. Assim, esta tese tem por objetivo realizar uma investigação detida de alguns eixos que nos parecem fundamentais e que surgiram conforme a análise do texto indicava caminhos e leituras. A partir do exame dos procedimentos de vanguarda mobilizados no romance (notadamente, colagem e montagem), começaram a se desenhar questões acerca da configuração do tempo, do espaço e da composição das personagens. A constelação criada por esses elementos expressava, por sua vez, os dilemas e as contradições de um país que começava a deixar a sua posição ainda culturalmente periférica, em um momento de euforia econômica, progresso técnico e transformação da posição geopolítica dos Estados Unidos.

Considerando esses aspectos, o primeiro capítulo antecede, em ordem, o processo do estudo. Trata-se de uma brevíssima apresentação das particularidades da situação estadunidense e de como estas aparecem nos escritos não ficcionais de Dos Passos. A discussão organiza-se em torno do tema da especificidade periférica dos Estados Unidos no âmbito cultural, sua relação com o modernismo internacional e com a produção industrial de bens culturais. Essa espécie de contextualização é importante porque ajudará a situar uma série de problemas que aparecerão, posteriormente, nas análises do romance e que foram instigados por elas. Algumas das questões mais específicas que Dos Passos já abordava em obras e textos anteriores iluminarão aspectos que são fundamentais para compreender as discussões que fazem parte do romance de 1925.

\footnotetext{
${ }^{31}$ MOREL, Jean-Pierre. John Dos Passos: Manhattan Transfer. Paris: Presses Universitaires de France, 1990.
} 
O segundo capítulo, por sua vez, procura desenvolver uma análise minuciosa e descritiva de certas características do romance. O objetivo desse primeira abordagem analítica é expor a estrutura do livro e demonstrar com clareza de que modo se constrói o que chamamos de forma de montagem literária, discutindo o uso de canções, propagandas e notícias de jornal no texto - expediente que caracterizamos como colagem. Ao recuperar todos esses materiais da realidade metropolitana e multiplicar o número de tramas e de anônimos que circulam pela Manhattan literária de Dos Passos, o romance constrói uma estrutura de vozes que explicitam o que chamei de insuficiência do herói, ou seja, a impossibilidade de condensar no percurso biográfico de uma personagem as tensões históricas das quais o livro pretendia dar conta.

Essa impossibilidade é discutida com mais atenção no terceiro capítulo, em que se procura demonstrar como o princípio estilístico do romance, apresentado no capítulo anterior, afeta não apenas a organização dos episódios múltiplos e autônomos mas também a estrutura interna das tramas e a própria constituição das personagens. Como se essas vidas transcorressem em entreatos, o romance rejeita a exploração narrativa dos acontecimentos mais importantes da história das personagens. Optando, ao contrário, pelo mergulho no detalhe cotidiano, cria biografias lacunares, tramas incompletas, expostas por um narrador impessoal e evasivo.

Essas biografias lacunares do romance dão sustentação ao argumento recorrente de que, em Manhattan Transfer, a metrópole é a protagonista do romance. Nessa ordem de ideias, o quarto capítulo pretende discutir como as técnicas empregadas pelo autor estão relacionadas a esse efeito. Nele, são analisadas a intersecção de diferentes temporalidades no romance, o apagamento da história - das personagens e da própria cidade - e a representação da metrópole como uma força maquinal. Essa força materializada em espaço condiciona o destino individual e coletivo (ou seja, determina também a própria noção de tempo). A esses elementos, articulam-se outros, por exemplo, a comparação de Nova York com grandes capitais imperiais (Roma, Babilônia, Nínive), a ausência do campo como polo dicotômico, a euforia do progresso técnico, a ideologia da máquina e as consequências da entrada e da subsequente vitória dos Estados Unidos na primeira Guerra Mundial.

A partir das análises e interpretações realizadas nos três capítulos anteriores, é possível compreender todos os aspectos que estão em jogo e de que maneira eles interagem. Após essa exposição, faz-se necessário dialogar com as críticas ao princípio organizador de todos esses elementos, a montagem. No quinto capítulo, portanto, será 
abordada a intervenção de Georg Lukács sobre Manhattan Transfer e os seus prolongamentos. Esse debate, feito nos anos 1930, é relevante porque mostra como essa década ressignificou, à luz dos grandes acontecimentos que a marcaram (a Depressão, ascensão do nazismo, criação da Frente Popular), os projetos modernistas dos anos anteriores. Contudo, será que o devir da história não provou que esses projetos artísticos tinham mais força do que as críticas faziam supor? É preciso compreender essa discussão em sua situação política, pois ela marcou boa parte das reflexões posteriores sobre a montagem e a colagem e ainda ressoa no ambiente acadêmico brasileiro.

O espírito crítico da obra de Dos Passos é um espírito de invenção. A sua forma permitiu ver nexos e desdobramentos nada evidentes de uma realidade, na época, muito recente. Apontou também os limites de projetos de futuros a partir do enraizamento de seu romance no presente. Nas considerações finais, gostaria de refletir por que hoje essa obra ainda desperta interesse e como ilumina um importante debate sobre o alcance e o poder de descoberta e invenção da literatura. 


\section{LONGLEGGED JACK: ANTES DO DILÚVIO}

To have great poets there must be great audiences too. Walt Whitman

Em 1911, estreava na Broadway o musical Pink Lady, e o seu sucesso foi imediato. Embora hoje seja uma peça esquecida e o nome de suas estrelas não tenha mais prestígio, o musical emplacou um número superior a 312 apresentações no mesmo ano e as suas canções fizeram parte do repertório de seu tempo. Ele aparece, de forma oblíqua, em Manhattan Transfer: Jimmy Herf está hospedado em uma pensão barata e, ao sair do banho, cantarola "flow, river flow" 32 . Assim como essa, muitas canções da época, jornais e propagandas são abundantes no romance e o preenchem não apenas de referências históricas imediatas mas também de significados que não são expressos na narrativa de forma explícita, sobrepondo ao texto diferentes camadas de sentido.

Armado sob essa constelação de referências, Manhattan Transfer, escrito em 1925, foi repetidamente aproximado, pela crítica e pelos leitores, ao Ulisses, de James Joyce. Dos Passos teve acesso à obra do autor irlandês quando esta foi publicada em 1922, na França, e escreveu com frequência sobre a influência do romance em sua produção. Em Manhattan Transfer, contudo, não há traços do virtuosismo erudito de Joyce. Ao contrário, as alusões mais significativas têm a sua origem na cultura de massa e de produtos industriais (o jornal, a propaganda), que aparecem, via de regra, desprovidos daquele tom paródico que permeia o romance irlandês. Além disso, esses elementos não são inseridos ao texto como mera curiosidade ou acessório para conferir cor local à narrativa, mas ganham uma dimensão profunda, significativa, pois são encarados como dados relevantes de sua cultura e de seu tempo. Considerar produtos da cultura de massa em chave séria é um dos aspectos mais importantes do texto e está associado ao processo histórico do desenvolvimento do modernismo nos Estados Unidos.

Durante muito tempo, lamentou-se a inaptidão do país para os "assuntos do espírito" e a sua aparente vocação para a fabricação de produtos rebaixados, como as canções populares das peças musicais tão difundidas na época. O tema sobre a

\footnotetext{
${ }^{32}$ DOS PASSOS, John. Manhattan Transfer. New York: First Mariner Books Edition, 2000, p. 146.
} 
“inclinação" dos Estados Unidos alimentou um amplo debate do qual Dos Passos, como a maioria dos artistas de sua geração, também fez parte. Embora os seus primeiros romances tenham sido publicados apenas a partir de 1920, a produção intelectual de Dos Passos começou antes, quando ainda era estudante em Harvard. Desde esse período, a reflexão sobre a literatura estadunidense, a industrialização e suas consequências para a produção cultural do país - e o que seria a "vocação da nação" - já figurava em seus textos.

Nos anos de Harvard, os seus escritos ficcionais e não ficcionais apareceram em contribuições frequentes para a revista universitária Harvard Monthly (da qual foi também editor em 1915). Entre resenhas de romances e antologias, artigos sobre política, poesias e pequenos textos em prosa, é possível destacar ao menos duas publicações frequentemente comentadas pela crítica e significativas para o desenvolvimento de sua obra literária. A primeira delas é "A Humble Protest", um libelo que pretende discutir os efeitos do desenvolvimento técnico e industrial sobre "a autoexpressão do ser humano". A desigualdade social e a opressão do trabalho desumano e sem sentido para o sujeito - este último fruto da Revolução Industrial teriam corrompido a habilidade do homem para viver e cultivar uma verdadeira “expressão de vida". Dos Passos se questiona se a "era da máquina” - após, supostamente, ter libertado a humanidade de um mundo regido por divindades transcendentais - não reivindicaria, como outrora, o sacrifício do humano, e conclui a sua argumentação associando a barbárie da guerra à industrialização mais desenvolvida ${ }^{33}$.

Essas considerações acerca da relação entre transformações sociais e o avanço técnico têm um significado particular no contexto estadunidense: cabe lembrar que, até 1850, os Estados Unidos ainda podiam ser considerados um país subdesenvolvido. É só na segunda metade do século XIX que a indústria no norte do país alcança uma expansão acelerada a ponto de, por volta da virada do século, a sua produção "superar aquela de seus dois principais rivais, a Grã-Bretanha e a Alemanha, combinadas"34.

\footnotetext{
33 "The one modern nation which, as well as having developed the industrial system to its highest degree, has a really great living art has suddenly slipped back into barbarism". DOS PASSOS, John. A Humble Protest (1916). In: PIZER, Donald (Org.). John Dos Passos: the major nonfictional prose. Detroit: Wayne State University Press, 1988, p. 34.

${ }^{34}$ BRADBURY, Malcolm; TEMPERLEY, Howard. Introdução. In: BRADBURY, Malcolm; TEMPERLEY, Howard (Eds.). Introdução aos estudos americanos. Rio de Janeiro: ForenseUniversitária, 1981, p. 26. Ver também LEE, Brian; REINDERS, Robert. A perda da inocência: 18801914. In: BRADBURY, Malcolm; TEMPERLEY, Howard (Orgs.). Introdução aos estudos americanos. Rio de Janeiro: Forense-Universitária, 1981, p. 224.
} 
As indagações que o jovem Dos Passos expõe nesse breve artigo são significativas, pois compõem um conjunto de reflexões que marcou o desenvolvimento artístico da sua obra na década de 1920 e de 1930, sendo fundamental para a composição de Manhattan Transfer.

A relação entre os dilemas do avanço da industrialização e a formação da cultura estadunidense aparece de forma bem tênue nesse primeiro artigo, mas é aprofundada em textos posteriores, como "Against American Literature", também divulgado incialmente na Harvard Monthly. Esse artigo representou um importante avanço para o jovem autor: aceito para publicação pela New Republic, em 1916, não só foi a sua primeira produção remunerada como teve uma circulação maior do que o periódico da universidade de Harvard poderia proporcionar. A principal linha de argumentação do texto se ancora na ponderação, nada original no contexto norteamericano (quiçá americano em geral), de que haveria uma ausência de matéria histórica nacional capaz de fornecer bases sólidas para a literatura estadunidense ${ }^{35}$. Em comparação com os romances europeus ou russos, por exemplo, a produção dessa jovem república, cultivada no solo árido da Nova Inglaterra, não passaria de um toco sem raiz, cortado do carvalho frondoso da Inglaterra ${ }^{36}$. Em uma análise certamente exagerada e que desdenhava grandes escritores de seu tempo, como Edith Wharton, Dos Passos argumentava que a falta de uma tradição com fortes raízes populares, as quais poderiam estar ancoradas, por exemplo, no folclore, gerou um corpo de obras sem sustentação - obras presas ainda a um modo de escrita contido e bemcomportado. Mesmo quando discute um autor como Walt Whitman, considerado por Dos Passos uma exceção no espectro da literatura nacional, ainda aí os problemas da jovem nação se fariam sentir: Whitman não conseguiu dialogar com os leitores de seu tempo, um público ainda preso a convenções literárias regidas pelos aspectos moralistas de sua tradição. Contudo, para Dos Passos, a única resposta possível ao dilema da nova nação seria dar continuidade ao projeto whitmaniano. Em vez de tentar recriar uma relação orgânica com a terra, retorno impossível dado o avanço do processo de industrialização, seria necessário cantar o futuro e sonhar a posteridade.

\footnotetext{
35. DOS PASSOS, John. Travel books \& other writings. New York: The Library of America, 2003, p. 588 .

36 "American literature is a rootless product, a cutting from England's sturdy well branched oak tree (...). In other countries literature is the result of long evolution". DOS PASSOS, John. Travel books \& other writings, cit., p. 588.
} 
Nesse sentido, há dois pontos interessantes a serem notados: o primeiro é a menção a Walt Whitman, influência fundamental e reconhecida para a obra posterior de Dos Passos. Whitman é um dos únicos escritores norte-americanos frequentemente citados pelo autor nos primeiros decênios de sua carreira ${ }^{37}$. Conforme observa Michael Clark, durante os seus anos de estudo em Harvard, Dos Passos não cursou nenhuma matéria sobre literatura dos Estados Unidos e, em geral, as universidades locais mostravam pouco interesse pela literatura ou história do país ${ }^{38}$. Contudo, indagações sobre em que consistia o seu país e o que o impedia de configurar uma produção cultural significativa estavam presentes em seus primeiros textos, retornando com frequência em seu diário ${ }^{39}$. O segundo aspecto que merece ser destacado é o de que, assim como a maioria de artistas seus conterrâneos, o jovem estudante sentia, ainda em 1916, faltar à literatura - ou mesmo à cultura - nacional um dado singular pelo qual esta se distinguiria da tradição da antiga metrópole e formaria uma produção coletiva significativa. Essa perspectiva bastante difundida colocava em questão, já no século XX, a própria existência da literatura estadunidense $^{40}$. Na mesma época, para ajudar o jovem T. S. Eliot a convencer o seu pai de que era imprescindível permanecer na Inglaterra, Ezra Pound vale-se dessa lógica acerca da cultura estadunidense. Em uma carta enviada para o senhor Eliot,

\footnotetext{
${ }^{37}$ A importância de Walt Whitman como uma referência nacional para essa geração pode ser constatada, por exemplo, pelo fato de que quase todos os textos não ficcionais que tratam de literatura na primeira edição da revista The Seven Arts mencionam Whitman como o grande autor dos Estados Unidos. O artigo do francês Romain Rolland, nessa edição inaugural da revista, ecoa (e, assumindo o papel comum naquela época do artista europeu, sanciona) as inúmeras vozes nacionais que reconheciam em Whitman um "Homero" do Novo Mundo: "Behind you, alone, the elemental Voice of a great pioneer, in whose message you may well find an almost legendary omen of your task to come,-your Homer: Walt Whitman". ROLLAND, Romain. America and the Arts. The Seven Arts, New York: The Seven Arts Publishing Co., v. 1, n. 1, p. 51, 1916.

${ }^{38}$ CLARK, Michael. Dos Passos's early fiction, 1912-1938. Cranbury, NJ: Associated University Presses, 1987, p. 14. Clark cita um depoimento iluminador de Malcolm Cowley sobre o tema em "Exile's Return": "It often seems to me that our years in school and after school, in college and later in the army, might be regarded as a long process of deracination. Looking backward, I feel that our whole training was involuntarily directed toward destroying whatever roots we had in the soil, toward eradicating our local and regional peculiarities, toward making us homeless citizens of the world". COWLEY, Malcolm apud CLARK, Michael. Dos Passos's early fiction, cit., p. 14. Lisa Nanney também comenta que "as was the case generally in American academics at the time, Harvard communicated the view that American writing was insufficiently developed to warrant much critical study”. NANNEY, Lisa. John Dos Passos. New York: Twayne Publishers, 1998, p. 29.

${ }^{39}$ CLARK, Michael. Dos Passos's early fiction, cit., p. 15. Clark cita, por exemplo, o texto nunca publicado "Art and Baseball" (parte dos arquivos do autor da Universidade de Virgínia, nos Estados Unidos), no qual o autor examina por que não há "arte nos Estados Unidos". Para ele, a transformação desse estado de coisas dependeria não da pesquisa sobre outros países e tradições, mas do desenvolvimento de "algo novo".

${ }^{40}$ Um dos professores de Dos Passos em Harvard, Barrett Wendell, afirmava categoricamente que não existia literatura estadunidense. BERNARDIN, Charles W. Dos Passos' Harvard Years. The New England Quarterly, v. 27, n. 1, p. 13, Mar. 1954.
} 
Pound argumenta que "Henry James ficou em Paris e leu Turgueniev e Flaubert, o Sr. Howells retornou aos Estados Unidos e leu Henry James" ${ }^{\text {"41 }}$. Ezra Pound, ele mesmo instalado em Londres, aponta, por meio da fórmula jocosa, mas não de todo inconsequente, essa sensação comum de que o ar rarefeito da ex-colônia turvava a perspectiva necessária para a formação de um grande poeta ${ }^{42}$. Seja em se tratando de versos, prosa ou música, o dilema parece sempre o de que o país seguia "dedicado à produção industrial" e negligente em relação à cultura ${ }^{43}$, pouco confiante em seus próprios potenciais ${ }^{44}$, uma vasta província ${ }^{45}$, variando de moda conforme o vento que sopra das artes continentais ${ }^{46}$.

Portanto, se o jovem Dos Passos não identificava nas obras de seus conterrâneos um traço característico capaz de distinguir a tradição literária de seu país, tal desconforto não era privilégio seu e tinha fundamento histórico. Como antiga colônia, os Estados Unidos enfrentaram, na formação de sua literatura nacional, dilemas similares aos de outros territórios colonizados. As produções escritas durante o período colonial ainda não constituíam um sistema literário, segundo a definição de Antonio Candido - definição esta que ajuda a estabelecer parâmetros definidos para distinguir o momento de transformação no qual a produção nacional rompe o vínculo de dependência em relação à tradição de sua metrópole. Jonathan Edwards, St. Jean de Crèvecoeur e John Woolman, por exemplo, produzem relatos significativos e consideravelmente difundidos acerca da sociedade estadunidense no século XVIII. A constituição de um sistema literário, todavia, só passa a ganhar contornos claros a partir da Independência dos Estado Unidos, quando, ao lado de um empenho novo em

\footnotetext{
41 "Henry James stayed in Paris and read Turgenev and Flaubert, Mr. Howells returned to America and read Henry James." POUND, Ezra. Ezra Pound to Henry Ware Eliot, 28 June 1915. In: ELIOT, Valerie; HAUGHTON, Hugh (Eds.). The letters of T. S. Eliot. New Haven: Yale University, 2011. v. 1 - 1898-1922, p. 110.

${ }^{42}$ Em uma carta de 1921 para Edmund Wilson, F. Scott Fitzgerald admite, com amargura, a veracidade da provocação do amigo sobre a situação periférica de Nova York, mas prevê o desdobramento de transformações que já estavam em curso: "You may have spoken un jest about New York as the capital of culture but in 25 years it will be just as London is now. Culture follows money and all the refinements of aestheticism can't stare off its change of seat (Christ! What a metaphor). We will be the Romans in the next generations as the English are now". FITZGERALD, F. Scott apud LENA, Alberto. The colors of New York. Racism, historicism and site in F. Scott Fitzgerald's The great Gatsby. In: BOELHOWER, William; SCACCHI, Anna (Eds.). Public space, private lives. Race, gender, class and citizenship in New York. 1890-1929. Amsterdam: VI University Press, 2004, p. 210. ${ }^{43}$ DREISER, Theodor. Life, Art and America, cit., p. 369.

${ }^{44}$ ROSENFELD, Paul. The American Composer. The Seven Arts, New York: The Seven Arts Publishing Co., v. 1, n. 1, p. 51, 1916.

${ }^{45}$ WHITTAKER, James. Musik or Music? The Little Review, Literature Drama Music Art, Chicago: Margaret C. Anderson, v. 2, n. 2, p. 18, 1915.

${ }^{46}$ BROOKS, Van Wyck. Young America. The Seven Arts, New York: The Seven Arts Publishing Co., v. 1, n. 2, p. 147, 1916.
} 
formar um sentimento de nação ${ }^{47}$, é possível verificar o começo de um acúmulo progressivo de produções vinculadas a esse anseio ${ }^{48}$. Como argumentam Marshall e Walker, após a vitória dos Estados Unidos em um conflituoso processo de independência, acreditava-se que a construção da literatura nacional funcionaria como uma espécie de demonstração de que um novo período se iniciava ${ }^{49}$. Essa aspiração não delineia um curso homogeneamente progressivo, muito menos imediato. Para vários artistas, ainda no início do século $\mathrm{XX}$, qualquer potencial latente no desenvolvimento de uma cultura estadunidense independente parecia permanentemente contido por duas forças primordiais da constituição do país colonial: "os puritanos emocionalmente reprimidos, impedindo a exploração dos sentidos, e os pioneiros materialistas procurando por novas terras e riquezas" ${ }^{\natural 0}$. No já comentado artigo "Against American Literature", Dos Passos associa a ausência de raízes populares à configuração das diversas formas norte-americanas de protestantismo, cuja tendência à abstração se refletiria no tipo de criação literária produzida nos Estados Unidos. Aqui talvez possamos estabelecer inclusive uma relação com o artigo "A Humble Protest", pois a industrialização lamentada pelo autor era também algo ideologicamente afinado com a tradição puritana de seu país. ${ }^{51}$ Essas relações entre o tipo de progresso que Dos Passos via tomar forma nos Estados Unidos, a tradição puritana e certo veio moralista ajudam igualmente a compreender o interesse desse jovem escritor por Whitman: não uma negação do progresso em si, mas uma crítica ao seu uso de então.

Mesmo na virada do século XX, a crítica não só à literatura nacional mas também à própria possibilidade de uma literatura estadunidense ainda era uma questão de primeira ordem. Diante desse sentimento de desvantagem cultural em relação às nações continentais, a elite econômica do país tinha por costume - como é

\footnotetext{
47 “Até 1763, há poucas indicações de que os colonos ansiavam por tal acontecimento [desligar-se da metrópole], ou até mesmo estivessem dispostos a contemplá-lo. O que alterou a situação, e acabou provocando os colonos a pegar em armas, foi a determinação do Governo britânico, depois da derrota dos franceses na guerra com os índios, de impor controles mais rigorosos sobre suas possessões imperiais." MARSHALL, Peter; WALKER, Ian. A primeira nova nação. BRADBURY, Malcolm; TEMPERLEY, Howard (Orgs.). Introdução aos estudos americanos. Rio de Janeiro: ForenseUniversitária, 1981, p. 66.

48 "Just two hundred years ago, when Americans had completed their Revolution and where proudly feeling their identity as the First New Nation (...) there was American writing, but there was no American literature". BRADBURY, Malcolm; RULAND, Richard. From puritanism to postmodernism. A history of American literature. New York: Viking, 1991, p. xi.

${ }^{49}$ MARSHALL, Peter; WALKER, Ian. A primeira nova nação, cit., p. 76.

${ }^{50}$ CORN, Wanda. The great American thing: modern art and national identity. Berkeley; Los Angeles: University of California Press, 1999, p. 12.

${ }^{51}$ LEE, Brian; REINDERS, Robert. A perda da inocência: 1880-1914, cit., p. 239.
} 
hábito nas nações colonizadas - enviar os seus jovens para viagens de formação pela Europa. De igual modo, isso ocorreu com Dos Passos, cujas condições familiares singulares fizeram com que boa parte de sua infância e adolescência transcorresse em terras estrangeiras ${ }^{52}$.

Em sua terra natal, na qual se sentia duplamente um estrangeiro, após tantos anos no exterior, Dos Passos percebia que essa sensação pessoal de deslocamento encontrava um correlato na literatura e na árida vida cultural do país, que muitas vezes parecia estagnada. O ano de 1913, contudo, conheceu um evento que movimentou o universo artístico do país: a famosa International Exhibition of Modern Art, mais conhecida como Armory Show, foi a primeira grande exibição de artes plásticas modernistas nos Estados Unidos. Já havia, é claro, o círculo reunido em torno do fotógrafo Alfred Stieglitz e a Galeria $291^{53}$. Com exposições que divulgavam novos artistas, como John Marin, Marsden Hartley, Arthur Dove, Edward Steichen e tantos outros, a galeria também propunha um cronograma de exposições que contou com peças de August Rodin, Henri Matisse, Paul Cézanne e Picasso. De toda forma, a exposição de 1913 foi excepcional pelo número de obras apresentadas (quase mil e trezentas) e pelo público diverso que foi capaz de reunir. Além disso, marcou um estágio de adensamento das produções nacionais dispersas, que, a partir de então, ganharam mais fôlego. Essa primeira grande exibição de arte moderna trouxe para o país ainda largamente conservador em artes uma notável amostragem de obras do modernismo europeu. Relembrando o evento, William Carlos Williams recorda como a exposição marcou a sua produção e a de os seus contemporâneos, dizendo que gargalhou ao ver "Nu descendo as escadas", de Duchamp, "feliz, aliviado",54.

\footnotetext{
${ }^{52}$ Nascido em 1896, John Madison, como foi então registrado, era filho ilegítimo de um importante advogado, John Randolph Dos Passos, e Lucy Madison, viúva de uma família proeminente de Petersburg, na Virgínia. John R. só pode assumir seu relacionamento com Lucy e adotar o jovem Jack (apelido de Dos Passos) como enteado após o falecimento de sua esposa, em 1910. Essas circunstâncias fizeram com que, até 1907, mãe e filho vivessem boa parte dos anos no exterior, principalmente na Bélgica e Londres. Após seu filho passar nos exames para a admissão em Harvard, John R. o enviou para uma viagem de formação pela Europa e o Oriente Próximo, durante a qual ambos trocavam cartas em francês. Quando retornava a sua terra natal, Dos Passos dizia sentir-se "duplamente estrangeiro".

53 "Stieglitz montou no ático do prédio na Quinta Avenida um espaço onde fotógrafos e artistas modernos dos EUA podiam ser apoiados e divulgados lado a lado com as revelações relativamente recentes de Paris, como Pablo Picasso, Paul Cézanne, Auguste Rodin, Francis Picabia, Henri-ÉmileBenoît Matisse, basicamente o who's who da pintura do início do século XX.” MALOSSI, Gustavo Mor. A construção de sentidos dissidentes de americanismo na revista Seven Arts (1916-1917). 2017. Dissertação (Mestrado em História) - Instituto de Ciências Humanas e Filosofia da Universidade Federal Fluminense, Niterói, 2017, p. 58.

${ }^{54}$ KALAIDJIAN, Walter. Introduction. In: KALAIDJIAN, Walter (Ed.). The Cambridge companion to American modernism. Cambridge: Cambridge University Press, 2005, p. 3.
} 
Não é por acaso que a versão original e mais completa do Armory Show tenha sido organizada primeiro em Nova York, onde Dos Passos se estabeleceria na década de 1920. A metrópole já era, nessa época, o grande centro cultural dos Estados Unidos, superando a concorrência representada pela grande cidade industrial de Chicago. Nova York certamente não foi o único centro modernista dos Estados Unidos. Muitos grupos floresceram inclusive em Boston, a capital puritana da Nova Inglaterra, onde morava W. D. Howells - um dos nomes mais importantes na esfera cultural nesse momento. Quando Howells mudou-se para Nova York, a sua decisão simbolizou o fim de uma era em que Boston exercia um forte controle sobre a vida intelectual dos Estados Unidos, atuando como uma espécie de sede do que ficou conhecido como a "genteel tradition" e determinando o que poderia ser publicado e o que deveria ser discutido $^{55}$ :

Durante boa parte do século XIX, a importância cultural de Nova York permaneceu inferior à de Boston, lar de Harvard, Atlantic Monthly, e outros bastiões da "genteel tradition". Contudo, entre 1850 e 1890, a égide da autoridade cultural deslocou-se para Manhattan ${ }^{56}$.

De fato, quando Nova York e Chicago começaram a crescer economicamente, Boston, essa antiga capital, perdeu o seu papel tradicional, e o mercado cultural do país passou a ser disputado pelas metrópoles industrializadas. Impulsionada por uma elite industrial que procurava incentivar jovens artistas, a cena cultural de Chicago explodiu por volta de 1900 e dava mostras de estabilidade. Nos anos 1890, a sua população chegou a 1.100.000 habitantes, aproximando-se, portanto, da aglomeração colossal de Manhattan, com os seus 1.515.000 habitantes. Para Nova York, Chicago representava o perigo real de perder os bancos estrangeiros e as firmas de exportação até então instaladas na ilha de Manhattan. Quando Chicago venceu a disputa iniciada em 1882 para sediar a Feira Universal em homenagem aos 400 anos da chegada de Colombo à América, parecia urgente tomar medidas que revertessem o que prefigurava uma tendência grave. Contudo, Nova York era mais do que um centro comercial movimentado que agregava os meios de publicação e de divulgação necessários à nova literatura da época: com a consolidação de suas fronteiras atuais

\footnotetext{
${ }^{55}$ Tradução nossa do original: "Through much of the nineteenth century, New York's cultural stature remained inferior to that of Boston, home of Harvard, Atlantic Monthly, and other genteel bastions. Yet from 1850 to 1890 , the aegis of cultural authority did shift to Manhattan". HOMBERGER, Eric. Chicago and New York: two versions of American Modernism. In: BRADBURY, Malcolm; MCFARLANE, James (Eds.). Modernism - 1890-1930. New Jersey: Humanities Press, 1976, p. 151.

${ }^{56}$ SCOBEY, David. M. Empire city: the making and meaning of the New York city landscape. Philadelphia: Temple University Press, 2002, p. 40.
} 
(conhecida como a consolidação da Grande Nova York, que será discutida nos próximos capítulos), no fim do século XIX, esse antigo entreposto comercial da Companhia das Índias Ocidentais se tornou a segunda maior metrópole do mundo e materializou, para os visitantes estrangeiros, uma imagem expressiva de um novo mundo da industrialização.

Com esses atributos, Nova York recebeu uma afluência intensa de artistas europeus no início da década de 1910 e, principalmente, durante a Primeira Guerra Mundial - o que também contribuiu para que se consolidasse como o grande centro do modernismo estadunidense. Artistas como Duchamp, Picabia, Juliette Roche e Albert Gleizes mudaram-se para Nova York, e esse deslocamento geográfico é correlato de um processo de inversão de perspectiva ${ }^{57}$ determinante para a formação do modernismo nos Estados Unidos. Na primeira edição da revista Broom, em 1921, Emmy Veronica Sanders acusava o que ela caracterizou como uma "invasão americana na Europa": em vez de os Estados Unidos oferecerem aos países europeus aquilo que de melhor poderiam criar, essa jovem nação se contentaria em ostentar artigos "iluminados eletricamente: verdadeira descendência de sua mãe, a Máquina"58. Sanders está certa ao apontar a predominância desses aspectos "industriais" na "exportação" dos produtos culturais estadunidenses. A ironia consiste no fato de a escritora não perceber que os elementos "vulgares" que ela critica serem justamente os mais valorizados pelos mesmos artistas que ela, escrevendo em uma revista dedicada à veiculação das artes modernistas, pretendia agradar.

Essa valorização, a partir do olhar estrangeiro, dos "bens materiais" nacionais desprezados pela elite intelectual do país teve início pelo menos uma década antes da criação da revista Broom, com a citada afluência de artistas. Se, do ponto de vista cultural, a direção do olhar ocorria, via de regra, da jovem nação em direção ao velho continente, agora também o Novo Mundo parecia tornar-se objeto de interesse dos europeus. O crítico Edmundo Wilson notava, na época, como os artistas que saíam dos Estados Unidos para fugir "da máquina, das propagandas, dos elevadores e do jazz" acabavam descobrindo uma França fascinada e convertida justamente a esses

\footnotetext{
${ }^{57}$ WILSON, Edmund apud NORTH, Michael. Transatlantic transfer: little magazines and EuroAmerican Modernism. The Modernist Atlantic Conference, De Montfort University, p. 18, July 2007. Disponível em: <http://www.modmags.dmu.ac.uk/file/north_transatlantic transfer.pdf>. Acesso em: 04 jun. 2016.

${ }^{58}$ Tradução nossa do original: "true offspring of its parent, the Machine". SANDERS, Emmy Veronica. America invades Europe. Broom: an international magazine of the arts, v. 1, n. 1, p. 91, Nov. 1921.
} 
aspectos da cultura estadunidense ${ }^{59}$. Mais do que um mero centro industrial dos Estados Unidos, a cidade de Nova York passa a representar, para muitos artistas europeus, um símbolo de toda a América do Norte. Ademais, o rápido desenvolvimento dessa metrópole faz com que as imagens associadas a esse novo país - a indústria, os arranha-céus, os carros - assumissem a dimensão de uma alegoria da própria vida moderna. Se o exemplo mais sintomático da modernidade são os Estados Unidos, fazia-se necessário descobrir nele o lugar da arte, também moderna.

Nesse sentido, todos os aspectos que Dos Passos descreveu em seu artigo "A Humble Protest" como entraves para a constituição de uma cultura literária à altura das produções internacionais são revalorizados pelo olhar estrangeiro. Se para Dos Passos a ausência de raízes profundas no solo do novo continente fazia com que a literatura estadunidense carecesse de estofo, o valor do país residiria justamente nessa tradição tímida ou, ainda, na simples inexistência de tradição. Em tudo oposta ao peso da cultura europeia, no horizonte desse jovem país tudo parecia estar por ser construído pelo aço de arranha-céus, pelo progresso da indústria:

Se ao menos a América percebesse que a arte da Europa está acabada - morta - e que a América é o país da arte do futuro... Veja esses arranha-céus! A Europa teria alguma coisa mais linda do que isso?

Nova York é uma obra de arte, uma verdadeira obra de arte... E eu acredito que a ideia de demolir prédios antigos, antigas lembranças, é boa... Não se deveria permitir que os mortos fossem tão mais fortes do que os vivos ${ }^{60}$.

\footnotetext{
59 "In France they [young Americans] discover that the very things they have come abroad to get away from - the machines, the advertisements, the elevators and the jazz - have begun to fascinate the French at the expense of their own amenities". WILSON, Edmund apud NORTH, Michael. Transatlantic transfer: little magazines and Euro-American Modernism, cit., p. 5.

${ }^{60}$ Tradução nossa do original: "If only America would realize that the art of Europe is finished - dead and that America is the country of the art of the future... Look at the skyscrapers! Has Europe anything to show more beautiful that these? New York is a work of art, a complete work of art... And I believe that the idea of demolishing old buildings, old souvenirs, is fine... The dead should not be permitted to be so much stronger than the living". DUCHAMP, Marcel apud PERLOFF, Marjorie. The avant-garde phase of American Modernism. In: KALAIDJIAN, Walter (Ed.). The Cambridge companion to American modernism. Cambridge: Cambridge University Press, 2005, p. 195.
} 


\section{1 "I would give all the contemporary paintings in the U.S. for a few meters of} American films" ${ }^{61}$

A história do movimento modernista estadunidense está profundamente relacionada à tensão que se estabelece entre essa formação nacional, marcada pelo passado colonial, e projetos artísticos empenhados em criar - ou desvelar - os traços capazes de distinguir o caráter internacional da vanguarda e os aspectos singulares e nacionais. Apesar de o termo "modernismo europeu" ser uma simplificação que obscurece a complexidade e a diversidade dos inúmeros grupos e correntes congregados sob essa denominação forçada, há aspectos do futurismo, cubismo e dadaísmo que colaboraram para inverter o "equilíbrio de forças" que regia a relação cultural entre Novo e Velho Mundo. Por exemplo, a reconsideração da esfera da arte no contexto do "progresso" industrial permitiu reconhecer o processo da industrialização dos Estados Unidos e seus produtos como algo singular e especificamente moderno. Esse movimento, associado ao crescimento da economia do país e às mudanças sociais, é importante não apenas para a esfera da vanguarda artística estadunidense; segundo a análise de Walter Kalaodjian, tais mudanças acarretam uma transformação social paradigmática ${ }^{62}$. É interessante como, ainda na década de 1920, a suposta vocação do país para o campo da vida prática em oposição ao da vida do espírito é tema recorrente: no romance The professor's house, de Willa Cather, a construção da nova casa da família da personagem principal, o professor Godfrey St. Peter, é marcada pelo conflito acerca da incorporação arquitetônica de uma estrutura moderna - e, portanto, "nacional", - representada pelo "banheiro interno", com água encanada, que seria a grande contribuição dos Estados Unidos para o mundo ${ }^{63}$. Ainda nesse tema, impossível não pensar na obra "Fonte", de Duchamp: produzida justamente nos Estados Unidos, em parte com o fito de provocar a sensibilidade persistentemente conservadora dos modernistas estadunidenses. O

\footnotetext{
${ }^{61}$ Comentário do jornalista François Fosca sobre a primeira grande exibição de arte estadunidense em Paris, Three Centuries of American Art. Apud GUILBAUT, Serge. How New York stole the idea of modern art: abstract expressionism, freedom, and the Cold War. Chicago; London: The University of Chicago Press, 1985, p. 42.

${ }^{62}$ KALAIDJIAN, Walter (Ed.). The Cambridge companion to American modernism. Cambridge: Cambridge University Press, 2005, p. 4.

63 "If your country has contributed one thing, at least, to civilization, why not have it?" CATHER, Willa. The professor's house. Lincoln: University of Nebraska Press, 2002, p. 12.
} 
resultado da provocação fez jus às intenções do autor, e a obra foi recusada no salão da Society of Independents.

Evidentemente, há uma pesada carga de idealização não só no elogio de alguns artistas europeus aos produtos da indústria e do desenvolvimento urbano, tal como se deu nos Estados Unidos, mas também em relação ao papel que eles próprios desempenharam na formação modernista do Novo Mundo. Além de certo exagero que descontava, nesse processo, a contrapartida nacional, Wanda Corn pondera, em The great American thing, que existia uma clara disparidade nas relações travadas entre os artistas estadunidenses e os europeus, cuja postura lembrava a de missionários encarregados de catequizar os nativos ${ }^{64}$. Na primeira edição da revista The Seven Arts, Romain Rolland escreveu um artigo bastante comentado sobre o papel da arte nos Estados Unidos, em um momento em que a guerra escurecia o horizonte do continente europeu. Em seu texto, Rolland não só assinala a capacidade de um país como os Estados Unidos - "sem tradições", que não tem, por sorte (!), "a perfeição da forma" e a "precisão das ideias" ${ }^{65}$ conquistadas pelos europeus - salvaguardarem o futuro do desenvolvimento da cultura mas, na verdade, prescreve como se deveria fazê-lo.

Além disso, a imagem criada e divulgada acerca da cidade e da vida estadunidense era, em certa medida, uma invenção. A “América” era, para Louis Aragon, "o país dos arranha-céus e caubóis, acidentes de ferrovias e coqueteleiras (...). Nós inventamos a lenda da América dez anos atrás, e agora é a vez dos Americanos acreditarem nela" ${ }^{\natural 6}$. É interessante que o autor francês tenha afirmado que chegava a hora de os próprios "americanos" acreditarem na lenda criada pelos europeus, ou seja, de que Nova York (em cuja imagem estariam resumidos os Estados Unidos) seria a grande capital cubista, futurista, com "arranha-céus estupendos, (...) prédios gigantescos e metrôs maravilhosos" ${ }^{" 67}$. Aragon tem razão ao ressaltar a importância desse olhar estrangeiro, capaz de desvelar aspectos significativos da cultura dos Estados Unidos. Contudo, um dos problemas desse mito "americano" era o peso da carga de idealismo nele contida. Os efeitos da forma do progresso técnico eram percebidos, pela maior parte dos artistas estadunidenses, com uma complexidade e ambivalência que escapava à visão, em alguma medida ingênua, dos europeus. $\mathrm{Na}$

\footnotetext{
${ }^{64}$ CORN, Wanda. The great American thing..., cit., p. 52.

${ }^{65}$ ROLLAND, Romain. America and the arts, cit., p. 47-48.

${ }^{66}$ Trata-se de uma citação de Elizabeth Eyre de Lanux, em que a artista registra uma conversa com o escritor Louis Aragon. Apud WINEAPPLE, Brenda. Genêt: a biography of Janet Flanner. Lincoln: University of Nebraska Press, 1989, p. 94.

${ }^{67}$ CORN, Wanda. The great American thing..., cit., p. 53.
} 
melhor produção modernista dos Estados Unidos, como é o caso da obra de Dos Passos, esse tema de primeira ordem aparece problematizado, com as tensões e nuances que lhe são características.

Quando Dos Passos retornou para Nova York em 1922, depois de uma viagem pelo Leste Europeu e o Oriente Médio ${ }^{68}$, a sua descrição da cidade foi marcada por uma impressão ambígua desse grande sonho futurista: "Nova York foi a primeira coisa que me surpreendeu. Era maravilhosa. Era horrenda. Tinha de ser descrita"69. Dos Passos, portanto, volta para os Estados Unidos e se estabelece em Nova York em um momento em que a arte estadunidense já é identificada com o próprio "modernismo urbano" $" 70$. Os produtos culturais populares, relacionados à indústria de massa, em particular, passam por uma vigorosa reconsideração. Matthew Josephson já havia notado em 1922, em um artigo publicado na revista Broom, que havia chegado a hora de rever, "com simpatia", os produtos nacionais e a sua "beleza autêntica", com o cinema, os billposters e suas sabedorias, os jornais ${ }^{71}$. Um dos grandes emblemas dessa importante reavaliação da arte popular relacionada à cultura de massa foi a publicação do livro de Gilbert Seldes, em 1924, The seven lively arts. Com ele, a arte de massa estadunidense, "que sequer era reconhecida como um possível campo de crítica", 2 , recebe um tratamento sério que a alça a um patamar inaudito. Nos ensaios que compõem o livro, são analisados desde o ragtime, passando por Chaplin, até uma curiosa tirinha de jornal, Krazy Kat. Admirada por muitos artistas da época, essa sequência em quadrinhos foi criada dois anos após a primeira tirinha diária aparecer nos jornais dos Estados Unidos, A Piker Clerk, seguida da famosa Jeff and Mutt (segundo muitos pesquisadores, uma possível influência para o pseudônimo escolhido por Duchamp ao assinar a obra "Fonte"). Para Seldes, o quadrinho Krazy Kay representava:

\footnotetext{
${ }^{68}$ Isso resultará, em 1927, no livro Orient express.

69 "New York was the first thing that struck me. It was marvellous. It was hideous. It had to be described.” [Tradução nossa.] DOS PASSOS, John. What Makes a Novelist (1968), cit., p. 271.

70 "By World War I, a certain kind of urban modernism had come to be considered so quintessentially American that many Europeans debated their own future in terms of capitulation or resistance to the American age." NORTH, Michael. Visual Culture. In: KALAIDJIAN, Walter (Ed.). The Cambridge companion to American modernism. Cambridge: Cambridge University Press, 2005, p. 180. Bernar De Voto, escrevendo sobre o romance The big money, comenta que, depois de sua viagem a Damasco, Dos Passos pôde se voltar "tenderly loving to those whom he had previously resented as vulgarians". DE VOTO, Bernard. John Dos Passos: Anatomist of Our Time (1936). In: MAINE, Barry (Org.). Dos Passos. The critical heritage. New York: Routledge, 1988, p. 122.

${ }^{71}$ JOSEPHSON, Matthew. The Great American Billposter. Broom: an international magazine of the arts, v. 3, n. 4, p. 305, Nov. 1922.

${ }^{72}$ NORTH, Michael. Reading 1922: a return to the scene of the modern. Oxford: Oxford University Press. 1999, p. 140.
} 
a obra de arte mais divertida e fantástica e satisfatória produzida hoje na América. (...) As qualidades de Krazy Kat são a ironia e a fantasia (...). Durante dez anos, diariamente, e frequentemente aos domingos, Krazy Kat aparecia na América; nesse período nós aceitamos e elogiamos centenas de falsificações vindas da Europa e da Ásia - peças bobas e vulgares, pintura ruim, óperas lastimáveis, religiões perversas, tudo que era cópia e vulgaridade esteve na moda entre nós; e um produto nativo honesto e genuíno passou despercebido até que no ano da graça 1922 um balé trouxe uma aclamação tardia e relutante ${ }^{73}$.

O livro de Seldes procura, portanto, reabilitar uma arte que, aparentemente, seria um produto da "ignorância", sem o prestígio do passado europeu e, por isso, estaria encoberta pela sombra de uma suposta "vulgaridade" culpada por ofuscar as qualidades inerentes à essa arte cultivada em solo nacional. O livro evidentemente foi recebido com muita desconfiança e rejeição, mas representa uma etapa de formalização desse processo: não se tratava mais de críticas sobre "arte popular" em revistas como The Dial ${ }^{74}$, mas, sim, de um livro proposto como uma obra de crítica séria, dedicado unicamente à arte de massa.

O crítico Hugh Kenner aponta como os anos 1910 e 1920 marcam também o momento em que o domínio da literatura inglesa havia deixado de ser definido por um país, a Inglaterra, para ser caracterizado pelo idioma, compartilhado inclusive por Irlanda e Estados Unidos, que estavam agora "produzindo literaturas nacionais substanciais em suas línguas" ${ }^{, 75}$. Nesse sentido, quando Dos Passos volta decidido a escrever sobre o seu país, a contundente frase de seu professor de Harvard, que afirmava não existir literatura nativa nos Estados Unidos, já parecia ultrapassada.

No ano de 1925 são publicados romances importantes para a tradição literária estadunidense, entre eles, The great Gatsby, de Scott Fitzgerald; An American tragedy, de Theodor Dreiser; e The professor's house, de Willa Cather. O quadro composto por essas ficções é interessante porque ilumina a novidade formal da obra de Dos Passos. Sem prejuízo da relevância dos romances citados, nenhum deles apresenta uma experimentação sequer similar ao projeto de Manhattan Transfer. Ainda que, em

\footnotetext{
${ }^{73}$ Tradução nossa do original: "the most amusing and fantastic and satisfactory work of art produced in America to-day. (...) The qualities of Krazy Kat are irony and fantasy (...). For ten years, daily and frequently on Sunday, Krazy Kat has appeared in America; in that time we have accepted and praised a hundred fakes from Europe and Asia - silly and trashy plays, bad painting, woeful operas, iniquitous religions, everything paste and brummagem, has had vogue with us; and a genuine, honest native product has gonne unnoticed until in the year of grace 1922 a ballet brought in a tardy and grudging acclaim". SELDES, Gilbert. The seven lively arts. New York: Harper and Brothers, 1924, p. 231.

${ }^{74}$ KAMMEN, Michael. The lively arts. Gilbert Seldes and the transformation of Cultural Criticism in the United States. New York: Oxford University Press, 1996, p. 86.

${ }^{75}$ KENNER, Hugh. The Making of the Modernist Canon. Chicago Review, v. 34, n. 2, p. 52, Spring 1984
} 
relação às obras anteriores de Dos Passos, o salto qualitativo e experimental tenha sido surpreendente, a radicalidade desse quarto romance tem raízes nas produções que ele já vinha desenvolvendo. Por um lado, as suas técnicas narrativas estão em diálogo com o processo de modernização e desenvolvimento do modernismo que vemos em seus textos teóricos. Por outro, ainda que de modo incipiente, elas já figuravam em suas primeiras ficções. Contudo, para além disso, o tema da guerra é a matéria principal desses primeiros romances e, como veremos, tem uma importância decisiva, embora não óbvia, em Manhattan Transfer.

O primeiro romance publicado por Dos Passos, One man's initiation -1917, de 1920, é financiado, em larga medida, pelo próprio autor e, por exigência da editora, sofre alterações de vocabulário após uma infrutífera resistência em favor da dicção coloquial e "autêntica" defendida pelo escritor. Esse livro de estreia é não só um fracasso comercial - apenas sessenta e três exemplares foram vendidos, sendo vinte e três adquiridos pelo próprio Dos Passos - como é largamente ignorado pelos críticos. Trata-se de uma narrativa bastante convencional em termos de construção do ponto de vista e de elaboração técnica. As experiências de Martin Howe - como o próprio Dos Passos, um motorista de ambulância na França durante a Primeira Guerra Mundial são narradas em uma construção convencional, com uso frequente do discurso indireto livre e abundância de diálogos. A abertura do romance apresenta um navio que parte em direção à guerra, carregando consigo os jovens combatentes em uma jornada que resultará na perda de expectativas e na conquista da maturidade por meio da decepção - daí o título do romance. A cena inicial de uma embarcação em água retornará em Manhattan Transfer, assim como certas imagens caras a Dos Passos que já aparecem aqui, a exemplo das "walls of Jericho". Porém, a qualidade desse primeiro romance ainda é muito distante do que encontramos nos melhores romances de Dos Passos e carece, sobretudo, de um tratamento mais cuidadoso com a matéria.

Também sobre a Primeira Guerra Mundial, Três Soldados foi publicado por Dos Passos em 1921, após ser recusado seguidamente por catorze editoras. A sua temática é, em larga medida, a mesma do romance anterior: uma denúncia da indústria da guerra como força alheia aos soldados obrigados a combater por uma causa que não diz respeito a esses homens oprimidos. Uma diferença na abordagem de Three soldiers é a associação feita no livro entre a guerra e o desenvolvimento da indústria - algo que se revela, por exemplo, nos títulos de cada um dos capítulos: 
"The Metal Cools", "Machines", "Rust", "Under the Wheels",76. Ao contrário de One man's initiation, contudo, a venda do livro é muito significativa e a crítica fala dele com interesse - ainda que, corriqueiramente, não tenha sido em tom elogioso. Viajando por Damasco, Dos Passos recebe as notícias de que o seu romance teve uma recepção ruidosa e controversa. Diferentemente do silêncio com o qual foi recebido One man's initiation, essa segunda ficção foi bastante discutida e até associada, por Francis Hackett (editor da New Republic), ao importante The red badge of courage, de Stephen Crane $^{77}$. Se para alguns críticos o livro era a primeira representação abrangente do exército dos Estados Unidos, um romance com uma "estrutura de aço",78, para outros, representava um "insulto nacional",79, não passando de uma "besteira", um "embuste", uma "imbecilidade" $" 80$.

Embora o tema fosse, a rigor, o mesmo de One man's, o que distingue as duas obras - e explica a diferença em sua recepção - é o trabalho formal de cada uma delas. Enquanto o romance de 1920 apresentava uma estrutura convencional, Three Soldiers elabora uma narrativa dividida em três centros de consciência distintos. A estrutura tripartite desse romance reflete três experiências de opressão pela máquina burocrática da guerra que não poderiam ser subsumidas a um único ponto de vista, embora todas denunciem o mesmo sistema. A pluralidade de centro de consciência é reforçada por um esforço de representação dos dialetos e sotaques distintos que compõem esse campo de soldados rasos em batalha contínua para salvar a sanidade em um cenário onde nada é são. A força do livro reside, portanto, na experimentação formal que responde a um problema de fragmentação da experiência. A fatura, ainda muito distante do radicalismo de U.S.A., representa um estágio inicial da pesquisa experimental que Dos Passos vai desenvolver durante a década de $1920^{81}$.

\footnotetext{
${ }^{76}$ Além disso, durante todo o romance há uma imagem recorrente de como os próprios homens tornamse máquinas: "Andrews thought suddenly of all the tingling bodies constrained into the rigid attitudes of automatons in uniforms like this one; of all the hideous farce of making men into machines". DOS PASSOS, John. Three soldiers. New York: Penguin Books, 1997, p. 278.

77 "Ele nos oferece um drama de guerra que tem o movimento, as cores vivas, de The Red Badge of Courage”. HACKETT, Francis. Doughboys. In: BARRY, Maine (Org.). Dos Passos. The critical heritage. New York: Routledge, 1988, p. 44.

${ }^{78}$ BISHOP, John Peale. Resenha (1921). In: BARRY, Maine (Org.). Dos Passos. The critical heritage. New York: Routledge, 1988, p. 32.

${ }^{79}$ DAWSON, Coningsby. Insulting the Army (1921). In: BARRY, Maine (Org.). Dos Passos: The critical heritage. New York: Routledge, 1988, p. 33.

${ }^{80}$ HALL, Norman Shannon. John Dos Passos lies! (1921). In: BARRY, Maine (Org.). Dos Passos: The critical heritage. New York: Routledge, 1988, p. 47.

${ }^{81}$ Antes de Manhattan Transfer, Dos Passos publica Streets of night, em 1923. O livro espanta o leitor que acompanha a obra de Dos Passos por sinalizar um retrocesso formal, já que se trata de um romance mais convencional (embora também flerte com diferentes focos de consciência) e muito menos bem-
} 


\subsection{Documentos da vida urbana}

Por meio da experimentação formal que Dos Passos já vinha desenvolvendo, em 1925, com Manhattan Transfer, ele é imediatamente associado ao modernismo literário. Nos Estados Unidos, no início da década de 1920, o modernismo era atacado, entre outras coisas, como uma "revolta artística" dos grupos étnicos e raciais em situação de inferioridade social. Royal Cortissoz, um crítico da New York Herald Tribune e feroz opositor do modernismo, para o qual ele cunha o reacionário termo de "Ellis Island Art”, critica abertamente o que considera uma intervenção estrangeira perniciosa no saudável corpo nacional:

Os Estados Unidos foram invadidos por estrangeiros, milhares dos quais constituem tantos graves perigos para a saúde do corpo público. O modernismo é precisamente da mesma origem estrangeira e heterogênea e está colocando em perigo a república das artes da mesma maneira ${ }^{82}$.

É comum também que os críticos do modernismo o associem, em chave negativa, à cultura de massa. O crítico Michael North discute essas relações em seu livro Reading 1922 e mostra por que esse é um tema controverso. Um exemplo interessante, levantado pelo pesquisador, é o de Paul Rosenthal, um dos primeiros a se manifestar para elaborar o que ele supunha ser uma defesa do modernismo contra a acusação de que os autores ligados ao movimento modernista seriam apenas "intellectual and artistic flappers". O curioso e revelador do caso é que Rosenthal reitera os mesmos termos da crítica, rejeitando a associação aos produtos "rebaixados" da cultura "popular", pois reivindica para o modernismo um estatuto de arte que o diferenciaria da cultura de massa. Em se tratando de Paul Rosenfeld, admirador fervoroso de Stieglitz, não causa espécie que a sua defesa fosse insistir no aspecto “diferenciado" da obra de $\operatorname{arte}^{83}$, já que o círculo de Stieglitz oscilava entre a divulgação e produção de arte moderna e uma concomitante recusa de que a arte

sucedido do que Three soldiers. O que explica essa aparente extemporaneidade é o fato de esse romance ter sido escrito basicamente nos anos em que o autor frequentava Harvard, por volta de 1916. Essa diferença entre o ano de publicação e a época de elaboração da obra também esclarece o aspecto deslocado desse romance em um momento da produção modernista da década de 1920, com a qual o autor já parecia vir dialogando.

${ }^{82}$ Tradução nossa do original: "The United States is invaded by aliens, thousands of whom constitute so many acute peril to the health of the body politic. Modernism is precisely of the same heterogeneous alien origin and is imperiling the republic of art in the same way". CORTISSOZ, Royal. American artists. New York: C. Scribner's Sons, 1923, p. 18.

${ }^{83}$ NORTH, Michael. Reading 1922. A return to the scene of the modern. New York: Oxford University Press, 1999, p. 143. 
dialogasse de forma profunda com os elementos do desenvolvimento industrial. Georgia O'Keefe, por exemplo, só pintou os seus primeiros quadros de temática urbana no fim da década de $1920^{84}$. O já discutido livro de Seldes mostra, contudo, a mudança de perspectiva em relação à arte nacional, marcante para o desenvolvimento do modernismo.

A obra de Dos Passos se insere nessa discussão porque apropria, na malha do "romance sério", elementos que a princípio estariam no campo oposto do espectro: jornais, notícias escandalosas, canções e publicidade - são elementos que estão em relação direta com a virada no modernismo estadunidense da qual falamos. Em outras palavras, em Dos Passos há um virtuosismo na mobilização de um material vasto e heterogêneo, na construção de camadas alusivas que também condensam o tempo histórico na forma artística. Todavia, é preciso enfatizar, como já dissemos, que a produção modernista mais consequente não explora esses elementos em chave ufanista ou ingênua. Em Manhattan Transfer, se a cultura de massa é incorporada como um dado significativo, não o é apenas por um viés positivo mas também de modo crítico. Apesar do olhar idealizado e, no sentido mais vulgar do termo, "romântico" de certos grupos modernistas acerca do desenvolvimento técnico tal como ocorreu nos Estados Unidos (especificamente, em Nova York), a experiência nacional desse processo fez com que a incorporação dos produtos de sua época (as notícias de jornal, canções, propagandas) fosse complexa: ao mesmo tempo em que iluminam lacunas, estabelecendo nexos que as tramas individuais não seriam capazes de indicar, instauram retornos que tornam a representação do tempo mais ambígua.

Além de incorporar, de forma complexa, esses materiais do cotidiano à representação literária de um centro urbano com Nova York, em Manhattan Transfer Dos Passos desenvolveu as relações entre a Primeira Guerra Mundial e as forças da industrialização - reflexão presente em seus dois romances anteriores. A novidade e a força da obra de 1925 residem no modo como se apropriou, na malha formal do texto, desses elementos para colocar em movimento as condições sociais das vidas e histórias que compõem essa metrópole literária.

\footnotetext{
${ }^{84}$ Para uma discussão sobre o papel do círculo de Stieglitz nas artes plásticas nos Estados Unidos, ver CORN, Wanda. The great American thing..., cit.
} 


\title{
2. SOBRE ILHAS E PONTES: COLAGEM, MONTAGEM E EXPERIMENTAÇÃO
}

\author{
from this bridge, \\ a geologist of the centuries \\ will succeed
}

in recreating our contemporary world.

"The Bridge", Maiakovsky

Após a publicação, em 1925, de seu quarto romance, John Dos Passos decidiu deixar Nova York e voltar para Paris, observando de longe a repercussão (muito expressiva, diga-se de passagem) do livro que tinha levado mais de dois anos para escrever. Se Manhattan Transfer foi recebido com espanto por alguns críticos, também provocou a indignação de outros, por exemplo, da elite cultural conservadora do país, a genteel tradition ${ }^{85}$. Para um de seus nomes mais ilustres na época, Paul Elmer More, o romance de Dos Passos representava não apenas o que "de mais baixo já se produziu" nos Estados Unidos: tratava-se de uma verdadeira "explosão em uma fossa" ${ }^{" 86}$. De todo modo, apesar de considerações conservadoras como esta, foram publicadas outras resenhas e críticas que, se não foram tão elogiosas quanto a de D.H. Lawrence $^{87}$ e Sinclair Lewis - para quem, na época de sua publicação, Manhattan Transfer podia ser considerado mais importante do que Ulysses ${ }^{88}$-, ao menos concordavam em ressaltar a presença de um experimento formal que distinguia a produção de Dos Passos daquelas de seus contemporâneos, e não apenas no que dizia

\footnotetext{
${ }^{85}$ Termo cunhado, em 1913, por George Santayana para caracterizar "a formidável elite que tinha governado o gosto e a sensibilidade norte-americana no século XIX”. SHI, David E. Facing facts. Realism in American thought and culture - 1850-1920. New York: Oxford University Press, 2005, p. 15.

86 "Explosion in a cesspool". MORE, Paul Elmer. Modern Currents (from The demon of the absolute, 1928). In: MAINE, Barry (Org.). Dos Passos: the critical heritage. New York: Routledge, 1988, p. 78.

${ }^{87}$ LAWRENCE, D. H. Review (1927). In: MAINE, Barry (Org.). Dos Passos: the critical heritage. New York: Routledge, 1988, p. 74-77.

${ }^{88}$ LEWIS, Sinclair. Manhattan at last! (1925). MAINE, Barry (Org.). Dos Passos: the critical heritage. New York: Routledge, 1988, p. 67-72. Há uma série de estudos e comentários dedicados à comparação entre os dois romances. Ver, por exemplo, HARDING, Desmond. Ulysses and Manhattan Transfer. A poetics of transatlantic modernism. In: Writing the city: urban visions and literary modernism. New York: Routledge, 2003, bem como MCLUHAN, Herbert Marshall. Dos Passos: technique vs. sensibility. In: HOOK Andrew (Org.). Dos Passos: a collection of critical essays. New Jersey: Prentice-Hall, 1974, p. 148-161.
} 
respeito à tradição da literatura estadunidense ${ }^{89}$. Embora lamente a inclinação pessimista explícita do livro, uma suposta falha partilhada com os impressionistas e "supernaturalistas",90, também Henry Longan Stuart, em uma resenha de primeira hora, salienta que se trata de uma "obra de arte potente e consistente" enfatizaram como uma experimentação técnica inovadora e consciente representava, na carreira de Dos Passos, um momento de maturidade, pois esse quarto romance radicalizava alguns procedimentos esboçados nas obras anteriores, superava suas fraquezas e, desde a primeira página, introduzia um tipo novo de experimentação na esfera do romance estadunidense ${ }^{92}$.

\subsection{I wish I was a skyscraper: arquitetura da voz narrativa}

O primeiro capítulo de Manhattan Transfer introduz, de imediato, uma série de procedimentos inusitados que o leitor encontrará ao longo do romance - inusitados tanto em 1920 quanto ainda hoje. Entre esses procedimentos, um dos mais marcantes é a justaposição brusca de elementos heterogêneos - fragmentos encadeados que são distintos uns dos outros em seu conteúdo. Para discutir em detalhe esse mecanismo de justaposição, vejamos como são elaborados os primeiros parágrafos do livro, cuja configuração já apresenta de forma sintética esse princípio estilístico recorrente e expõe o tom dominante da narrativa:

1) Three gulls wheel above the broken boxes, orangerinds, spoiled cabbage heads that heave between the splintered plank walls, the green waves spume under the round bow as the ferry, skidding on the tide, crashes, gulps the broken water, slides, settles slowly into the slip. Handwinches whirl with jingle of chains. Gates

\footnotetext{
${ }^{89}$ LUDINGTON, Townsend. John Dos Passos: a twentieth century odyssey. New York: E. P. Dutton, 1980. p. 242.

${ }^{90}$ Dos críticos de primeira hora, também Tucholsky associou o romance imediatamente ao naturalismo: "Manhattan Transfer é um bom livro - os americanos inventaram um novo Naturalismo, que ainda é demasiado jovem para se igualar ao velho [naturalismo] francês, mas é suficientemente cativante" [Tradução nossa do original: "Manhattan Transfer ist ein gutes Buch - die Amerikaner haben sich da einen neuen Naturalismus zurechtgemacht, der zu jung ist, um an den alten französischen heranzureichen, aber doch fesselnd genug"]. TUCHOLSKY, Kurt. John Dos Passos, Manhattan Transfer (1928). Disponível em: <http://www.textlog.de/tucholsky-passos-manhattan.html>. Acesso em: 14 maio 2017.

${ }^{91}$ Tradução nossa do original: "powerful and sustained piece of work". STUART, Henry Longan. Review (1925). MAINE, Barry (Org.). Dos Passos: the critical heritage. New York: Routledge, 1988, p. 67.

92 "Manhattan Transfer (1925) deserves to be recognized as the first truly modernist American novel. Of course, this early in his career Dos Passos did owe something to the previous generations of writers who, pursuing the new directions of realism and naturalism, had brought a non-genteel challenge to the pieties of conventional American letters. But in terms of formal articulation, of how a work of fiction is structured and communicated to the reader, Manhattan Transfer represents a break with the past". HOOK, Andrew; SEED, David. John Dos Passos, cit., p. 252.
} 
fold upwards, feet step out across the crack, men and women press through the manure smelling wooden tunnel of the ferry-house, crushed and jostling like apples fed down a chute into a press

The nurse, holding the basket at arm's length as if it were a bedpan, opened the door to a big dry hot room with greenish distempered walls where in the air tinctured with smells of alcohol and iodoform hung writhing a faint sourish squalling from other baskets along the wall. As she set her basket down she glanced into it with pursed-up lips. The newborn baby squirmed in the cottonwool feebly like a knot of earthworms

On the ferry there was an old man playing the violin. He had a monkey's face puckered up in one corner and kept time with the toe of a cracked patent-leather shoe. Bud Korpening sat on the rail watching him, his back to the river. The breeze made the hair stir round the tight line of his cap and dried the sweat on his temples. His feet were blistered, he was leadentired, but when the ferry moved out of the slip, bucking the little slapping scalloped waves of the river he felt something warm and tingling shoot suddenly through all his veins. 'Say, friend, how fur is it into the city from where this ferry lands?' he asked a young man in a straw hat wearing a blue and white striped necktie who stood beside him. ${ }^{93}$

O primeiro parágrafo é grafado em itálico e se assemelha a uma epígrafe, instaurando um modelo de abertura que será repetido em todos os capítulos do romance. A cena apresentada é panorâmica e acompanha a chegada de uma balsa a um porto não determinado. À exceção da menção às ondas verdes, não há qualquer descrição da paisagem natural, mas a atenção do leitor é direcionada para os elementos mais triviais que compõem a cena, como caixas quebradas e cascas de laranja. Em seguida, o texto se detém na lenta aproximação da balsa, acentuada pelo encadeamento das imagens utilizadas, desde a sonoridade travada de "skidding on the tide", que sugere o obstáculo das ondas para o avanço da embarcação, até culminar na ritmada e vagarosa aliteração de "slide, settle, slowly e slip". Avançando na cadência dos acontecimentos,

\footnotetext{
93 "Três gaivotas giram sobre as caixas quebradas, cascas de laranja, maços de couve estragados sacodem entre as paredes de tábua lascada, as ondas verdes espumam sob a proa redonda, conforme a balsa, acompanhando a maré, rompe, engole a água quebrada, desliza, atraca vagarosamente no ancoradouro. Manivelas giram com o retinir de correntes. Portões correm para cima, pés pisam fora da balsa pelas rachaduras, homens e mulheres se comprimem pelo túnel de madeira da estação das balsas cheirando a esterco, esmagados e empurrando-se como maçãs jogadas num tubo em direção ao espremedor./A enfermeira, segurando o cesto com os braços estendidos como se fosse uma comadre, abriu a porta da sala seca e quente com as paredes verdes destemperadas, onde, no ar impregnado de odores de álcool e iodofórmio, pairavam contorcidos nas paredes choros fracos e desafinados de outros cestos. Quando ela repousou o cesto, olhou dentro dele com os lábios contraídos. O bebê recémnascido se contorcia no meio do algodão como um aglomerado de minhocas./Na balsa havia um velho tocando violino. Ele tinha cara de macaco, retorcida para um lado, e marcava o compasso com a ponta de um sapato de couro surrado. Bud Kopernning sentou no corrimão olhando para ele, de costas para o rio. A brisa fez com que se arrepiassem os pelos em volta da linha justa de seu chapéu e secou o suor de suas têmporas. Seus pés estavam cheios de bolhas, ele estava chumbado, mas quando a balsa se afastou da rampa, batendo contra as pequenas ondas do rio, ele sentiu algo quente e fervilhante disparar de repente por todas suas veias. 'Diz, amigo, quão longe fica a cidade daqui de onde a balsa atraca?' ele perguntou prum jovem em chapéu de palha, vestindo uma gravata listrada de azul e branco que estava ao seu lado." [Tradução nossa.] DOS PASSOS, John. Manhattan Transfer, cit., p. 03.
} 
acompanhamos a abertura barulhenta dos portões. Antes de vermos as pessoas, ouvimos o ranger de seus passos nas rachaduras da madeira: passos de homens e mulheres que, ao fim, são reduzidos à imagem das maçãs utilizadas na produção industrial - associação reforçada pela coincidência do verbo to press com o substantivo press - aludindo às cascas de laranja sobrevoadas pelas gaivotas.

Logo após a abertura dos portões da balsa ("gates fold upwards”), que dão passagem a esses indivíduos utilizados na alimentação da grande máquina urbana, há uma descontinuidade temática, reforçada pelo duplo espaço em branco que separa o parágrafo inicial (terminando com “... into a press”) do segmento posterior ("The nurse...”). Nesse segundo parágrafo, há a descrição de um bebê carregado na maternidade até o berçário e um novo corte indicado graficamente pelo duplo espaçamento. A narrativa é então redirecionada para uma balsa. Embora esse trecho apresente três personagens (o violinista, Bud e o cavalheiro com gravata), a nomeação de apenas um dos três homens em cena sugere que o foco de atenção do leitor deve se direcionar a Bud Korpenning.

A partir dessa breve descrição da abertura do romance, a primeira consequência desse modo de exposição a ser destacada diz respeito às relações que o texto convida o leitor a estabelecer entre os fragmentos sintaticamente desconexos: pode-se associar a balsa em que Bud se encontra àquela que atraca no porto no primeiro parágrafo. Contudo, não há elementos textuais indicando se essa segunda balsa que chega a Manhattan é a mesma que o leitor acompanhou atracando no cais desconhecido sob o voo das gaivotas. Afinal, agora, quando a narrativa desvia o olhar da maternidade e foca em Bud, vemos uma balsa não atracada e de portões abertos, mas ainda em movimento, deixando um porto obscuro para, no parágrafo seguinte, aproximar-se do cais de Manhattan. Esse tipo de ambiguidade, que instiga o leitor a realizar associações não evidenciadas pelo texto, é recorrente, tem diversos desdobramentos e consiste em um resultado específico do princípio estilístico organizador de todo o texto, passível de ser descrito, nesse primeiro momento, como a justaposição de elementos descontínuos - elementos que, por sua vez, apresentam conteúdos heterogêneos.

Apesar (mas, talvez, também por causa) da visível descontinuidade narrativa entre os segmentos anteriormente destacados, há dois aspectos que unem esses fios e episódios heterogêneos. Em primeiro lugar, certa coincidência de um sentido figurado, na medida em que todos representam uma forma de chegada à metrópole e à narrativa; em segundo lugar, une-os também certo tom decadente, revelado pela opção por focar a 
descrição em resíduos e elementos em franca desintegração. Isso se revela, no primeiro parágrafo, na descrição das cascas de laranjas, das laterais quebradas das caixas de madeira, dos maços de couve boiando na água. No segundo parágrafo, o motivo do "pó ao pó" é desdobrado na associação do bebê às minhocas, do cesto à comadre - o feto expelido como resíduo corporal. Em um processo acumulativo, essas descrições se somam ao aspecto degradado da maternidade, com suas paredes esverdeadas e seu cheiro pungente, culminando, no episódio seguinte, nos detalhes que compõem a aparência desalinhada e maltrapilha de Bud.

Se, por um lado, há realmente um tom dominante que unifica a dispersão aparente desses cacos amontoados, por outro lado existe uma diferença de estilo bastante evidente. Conforme já comentamos, todos os capítulos do romance são abertos por um parágrafo inicial destacado graficamente do resto do texto pelo itálico. No caso específico do primeiro capítulo, há uma dicção lírica que orienta a leitura e que se traduz nas aliterações, na visada panorâmica que, de forma ambígua, instaura certo tom solene - justamente porque a voz se distancia do quadro degradado -, mas contido, que o associa a algo como um poema em prosa. Impossível não pensar, ao ler essa abertura, em “Crossing Brooklin Ferry”, de Walt Whitman:

\footnotetext{
I too many and many a time cross'd the river of old, Watched the Twelfth-month sea-gulls, saw them high in the/ air floating with motionless wings, oscillating their bodies,/

Saw how the glistening yellow lit up parts of their bodies and left the rest in strong shadow,

Saw the slow-wheeling circles and the gradual edging toward the south, Saw the reflection of the summer sky in the water. ${ }^{94}$
}

Nada mais distante da inclinação apaixonada do eu lírico do poema ("crowds of men and women attired in the usual costumes, how curious you are to me!') do que a indiferença mecânica desse olhar que, no romance, percorre a paisagem deteriorada do porto. Ademais, o tom menos solene e mais expansivo da poesia de Whitman reforça a sensação de unidade dos versos e do poeta com o ambiente. Apesar dessas claras diferenças, há essa diç̧ão lírica da abertura do romance, comentada anteriormente, que nos remete ao poema e que se distingue claramente do estilo expositivo dos parágrafos seguintes. Há, portanto, também em termos de estilo, uma descontinuidade recorrente.

\footnotetext{
${ }^{94}$ WHITMAN, Walt. Complete poetry and collected prose. New York: Literary Classics of the United States, 1982, p. 309.
} 
O primeiro capítulo é arquitetado, sobretudo, a partir da alternância entre cenas fragmentárias de duas histórias, a da família Thatcher e a de Bud Korpening - cujas tramas particulares desenvolverão enredos paralelos que não possuem qualquer relação de determinação ou necessidade mútua. A essas tramas, segmentadas e independentes entre si, são justapostos fragmentos heteróclitos desprovidos de continuidade no desenvolvimento do romance e que são encerrados abruptamente: é o caso do episódio que conclui o primeiro capítulo, no qual é descrita a caminhada de um judeu pela região do Lower East Side, no sul da ilha de Manhattan, até uma farmácia e, em seguida, até sua casa. É o caso também do segundo parágrafo do romance, em que uma enfermeira carrega um cesto com um bebê pela maternidade: esse breve episódio pode ser associado, pelo leitor, ao nascimento de Ellen. Contudo, como vimos no caso da balsa que traz Bud a Manhattan, não há qualquer indício explícito que confirme essa aproximação. Temos, portanto, dois tipos de fragmentos: um é parte constitutiva dessas histórias e de tramas que podem ser breves (a exemplo de Bud ou Anna Cohen) ou se desenvolver ao longo de todo o romance (conforme ocorre com Jimmy e Ellen); já o outro tipo se encerra em episódios curtos, isolados, como esquetes, que não serão desdobrados em outros fragmentos para formar um esboço de intriga particular.

Antes mesmo de começar a escrever este que seria seu quarto livro de ficção, o autor já havia definido como projeto de sua nova obra elaborar uma crônica do universo metropolitano e, para isso, o seu romance deveria "carregar uma carga muito pesada"95; o estilo que daria conta desse projeto, porém, não foi previsto, mas improvisado durante a escrita, como um verdadeiro experimento ${ }^{96}$. Desse experimento resultou um romance de "cento e cinquenta personagens cujas identidades nos é total ou parcialmente comunicada e um conjunto mais significativo ainda de anônimos, provavelmente em torno de duzentos e cinquenta" ${ }^{\text {97 }}$. Para sistematizar um pouco essa obra cujo excesso de partes autônomas dificulta, em uma primeira leitura, a possibilidade de visualização compreensiva do conjunto, vale relembrar que o romance está dividido em três partes: a primeira e a terceira parte do

\footnotetext{
95 Tradução nossa do original: "Carry a very large load". DOS PASSOS, John. "ontemporary Chronicles (1961), cit., p. 238.

96 "The style of writing had to be made up as I went along. It was all an experiment." DOS PASSOS, John. What Makes a Novelist (1968), cit., p. 272.

${ }^{97}$ MOREL, Jean-Pierre. John Dos Passos: Manhattan Transfer, cit., p. 21.
} 
romance possuem cinco capítulos, enquanto a segunda parte tem oito ${ }^{98}$. Contudo, como o crítico Volker Klotz ${ }^{99}$ apontou, há uma irregularidade na aparente simetria da composição: ao contrário do que essa estrutura tripartite poderia fazer supor, a primeira parte conta com 42 cenas; a segunda, 39; e a terceira, 55. Ou seja, embora a parte central do romance tenha um número maior capítulos e algumas páginas a mais (embora, no geral, o número de páginas seja distribuído de forma relativamente regular para as três seções do livro), ela possui menos cenas. Esse fato se traduz, na segunda parte do romance, em um número mais restrito de personagens novas e uma retomada constante das tramas que o leitor já acompanha desde o começo.

Esse movimento do início do romance até a segunda parte sugere, à primeira vista, um processo de familiarização do leitor e de controle do mundo ficcional: quanto mais o leitor entra em Manhattan, menor o número de novidades que ele encontrará, mais habituais tornam-se os rostos que ele reconhece nas ruas já percorridas. Essa impressão, contudo, não se sustenta. Conforme mostrou o crítico francês Jean-Pierre Morel, se tomarmos como medida de análise as personagens que aparecem ao menos duas vezes ao longo de todo o romance, da primeira parte para a segunda temos de fato uma diminuição de vinte para oito personagens novas reforçando a impressão de que haveria uma familiarização do leitor com o universo de histórias e o modo de apresentação. Entretanto, na última parte, há a introdução de dezoito novas figuras ${ }^{100}$. Para Volker Klotz, um dos elementos característicos desse movimento seria a formação de um ritmo nítido, como em uma sinfonia. $O$ andamento seria frenético na primeira parte, seguido de um ritmo mais lento para culminar em um andamento acelerado novamente na terceira parte, in prestissimo, quando o número de personagens inéditas é maior do que o de tramas retomadas. $\mathrm{O}$ final do romance ganharia, dessa forma, uma impressão de recomeço, de uma onda que se contrai para acumular força e dinâmica.

Estruturar um romance a partir de diferentes narrativas que se conectam de forma mais ou menos explícita não era algo exatamente novo. No romance vitoriano não faltam exemplos de estruturas que dependem da dispersão de fios narrativos, normalmente recolhidos por um narrador onisciente. É o caso, por exemplo, de Vanity

\footnotetext{
${ }^{98}$ Uma curiosa proximidade com o romance Ulisses, de James Joyce, no qual temos dois blocos de três capítulos e um de doze. Ver MOREL, Jean-Pierre. John Dos Passos: Manhattan Transfer, cit., p. 20.

${ }^{99}$ KLOTZ, Volker. Die erzählte Stadt. Ein Sujet als Herausforderung des Romans von Lesag bis Döblin. München: Carl Hanser Verlag, 1969, p. 317-371.

${ }^{100}$ Todos esses dados e estatísticas foram sistematizados com precisão na pesquisa de Jean-Pierre Morel. MOREL, Jean-Pierre. John Dos Passos: Manhattan Transfer, cit., p. 19-35.
} 
fair, de William Makepeace Thackeray, um romance muito apreciado por Dos Passos. O realismo estadunidense também já havia explorado a multiplicação de fios narrativos, como em $A$ hazard of new fortunes, de William Dean Howells. Recolhidas por um observador onisciente intruso que conduz todas as tramas, as relações entre cada fio é estabelecida pelo narrador. Ocorre que, em Manhattan Transfer, esse aspecto já presente em tantas obras anteriores é exacerbado. Em primeiro lugar, o número de tramas é multiplicado e o espaço conferido a muitas delas é reduzido, em alguns casos, a meia página. Além disso, se antes as diferentes tramas possuíam algum grau, ainda que tênue, de relação (em Vanity fair, de certa forma, todas convergem para Becky ou Amelia), no romance de Dos Passos a maioria delas não estabelece qualquer relação ou influência sobre as outras.

Nessa ordem de ideias, note-se, inclusive, uma mudança importante na posição do narrador: se antes o narrador onisciente intruso, na figura de um autor, participava ao leitor elementos e reflexões de uma ordem exterior à consciência das personagens, agora, ainda à distância do mundo ficcional, ele "procura desaparecer completamente por trás da ação que narra. (...) O autor não é um moralista, mas um anatomista que se contenta em dizer o que encontra no cadáver humano. Os leitores concluirão, se quiserem" ${ }^{\text {101 }}$. Some-se a isso o fato de que, entre boa parte dos segmentos narrativos, não se estabelece sequer a noção de encadeamento, seja cronológico, seja causal. Aos leitores cabe, portanto, a tarefa de organizar no mapa da cidade esse número exorbitante de personagens, muitas das quais não reaparecem e cujas histórias não têm desenvolvimento - o que diferencia o uso das tramas múltiplas do que era feito antes; afinal, não se trata de uma ou duas personagens que desaparecem, mas de uma verdadeira massa de vidas (em parte, anônimas), que o leitor mal chega a discernir.

Essa pluralidade de personagens respondia ao projeto inicial de Dos Passos, que procurava dar conta da diversidade desse espaço urbano cuja complexidade não cabia "na carreira de um herói" ${ }^{102}$. O resultado desse projeto foi a incorporação, em uma concatenação brusca e descontínua, dessas diversas histórias representadas tanto nas tramas - mais longas ou breves - quanto nos episódios isolados em que vemos as inúmeras vozes nativas e estrangeiras que compunham o espaço real de Manhattan:

\footnotetext{
101 ZOLA, Émile. Do romance. São Paulo: Editora Imaginário; Edusp, 1995, p. 98.

102 DOS PASSOS, John. What Makes a Novelist (1968), cit., p. 272. Pode-se encontrar uma formulação semelhante em: DOS PASSOS, John. Contemporary Chronicles (1961), cit., p. 238.
} 
2) 'Hello Emily!... Say Emily I've got a raise.'

'You're pretty near late, d'you know that?'

'But honest injun I've got a two-dollar raise.'

She tilted her chin first to oneside and then to the other.

'I dont give a rap.'

'You know what you said if I got a raise.' She looked in his eyes giggling.

'An this is just the beginnin...'

'But what good's fifteen dollars a week?'

'Why it's sixty dollars a month, an I'm learning the import business.'

'Silly boy you'll be late.' She suddenly turned and ran up the littered stairs, her pleated bellshaped skirt swishing from side to side.

'God! I hate her. I hate her.' Sniffing up the tears that were hot in his eyes, he walked fast down Hudson Street to the office of Winkle \& Gulick, West India Importers.

The deck beside the forward winch was warm and briny damp. They were sprawled side by side in greasy denims talking drowsily in whispers, their ears full of the seethe of broken water as the bow shoved bluntly through the long grassgray swells of the Gulf Stream.

'J'te dis mon vieux, moi j'fou l'camp à New York... ${ }^{103}$

Caminhando pela rua Hudson até o escritório onde acredita (ou quer fazer acreditar) estar aprendendo "the import business", o jovem anônimo desse trecho será esquecido pelo narrador e pelo leitor, como provavelmente o será pela namorada (esta, sim, nomeada). A discussão entre o casal é antecedida por uma cena breve em que vemos o jovem no refeitório do escritório em que trabalha - essas duas cenas compõem o único fragmento reservado em toda a extensão do romance a essas duas personagens. Dela, sabemos apenas o nome (Emily), como está vestida e um único traço físico: o seu queixo atrevido. Do anônimo também temos a única indicação de que se trata de um jovem ("young man"). Como normalmente ocorre entre os fragmentos (com algumas poucas exceções), temos um espaçamento duplo que evidencia a heterogeneidade dos trechos, separando-o do anterior e do seguinte e, imediatamente, uma cena com duas personagens novas que, em oposição ao casal,

103 “'Oi, Emily!... Olha, Emily, eu tive um aumento'. 'Você está bem atrasado, sabia disso?' 'Mas, palavra, eu tive um aumento de dois dólares.' Ela mexeu o queixo primeiro pra um lado, depois pro outro. 'Não estou nem aí'. 'Você sabe o que disse se eu ganhasse um aumento.' Ela olhou rindo nos olhos dele. 'E isso é só o começo'... 'Mas de que adiantam quinze dólares por semana?' 'Ué, são sessenta dólares por mês, e eu estou aprendendo o negócio de importação'. 'Seu tonto, vai se atrasar.' Ela virou de repente e subiu correndo as escadas, sua saia em forma de sino batendo de um lado pro outro. 'Deus, eu a odeio! Eu a odeio!' Fungando as lágrimas que estavam quentes em seus olhos, ele andou rapidamente pela rua Hudson até o escritório do Winkle \& Gulik, West India Importers. O deque ao lado do molinete estava quente e com umidade salgada. Eles estavam esticados lado a lado vestindo jeans engordurados falando sonolentamente aos sussurros, as orelhas cheias de respingo das águas que quebravam conforme a proa batia bruscamente contra as longas ondas cinza da Corrente do Golfo. 'J'te dis mon videux, moi j'fou l'camp a New York..."' [Tradução nossa.] DOS PASSOS, John. Manhattan Transfer, cit., p. 17-18. 
terão um desenvolvimento no decorrer da narrativa. Essa cena retirada do segundo capítulo da primeira parte mostra como o procedimento de apresentação das personagens se repete ao longo de todo o romance. $\mathrm{O}$ acontecimento (o rompimento de um suposto relacionamento entre dois jovens) é desprovido de qualquer importância para o desenvolvimento das outras tramas. É difícil para o leitor prever quais personagens vão reaparecer (certamente, não as anônimas) e quais serão deixadas pelo caminho: talvez Emily pudesse surgir em uma cena posterior, com o seu chapéu e o seu queixo atrevido? De toda forma, é importante notar como até as personagens cujas tramas seguimos no desenvolvimento da narrativa também aparecem para o leitor de forma fragmentada: temos apenas relances de alguns acontecimentos de suas vidas - e não necessariamente os mais importantes, expediente que vai de par com a falta de relevância do trecho comentado anteriormente e sobre o qual nos debruçaremos no próximo capítulo.

Um aspecto importante do romance, que reforça a fragmentação e a justaposição de pedaços descontínuos de tramas e episódios, é a incorporação de outro tipo de elemento textual, aquele que se refere a materiais não ficcionais retirados do cotidiano da metrópole. São canções populares da época, manchetes de jornais, anúncios de produtos muito conhecidos - em alguns casos, pouco -, placas e cartazes expostos ao transeunte da cidade e que são montados na complexa arquitetura literária de Manhattan Transfer. A escolha do procedimento estilístico para a configuração peculiar dessa estrutura narrativa, ainda que não tenha sido decidida de antemão ${ }^{104}$, não foi gratuita, mas, sim, uma tentativa deliberadamente não convencional de dar feição literária a um fenômeno peculiar - e aparentemente novo - da vida da multidão na metrópole na virada do século XX.

Se, algumas páginas antes, havíamos notado que o romance concatena fragmentos de conteúdo heterogêneo ao desenvolver simultaneamente as tramas de Ellen, Bud, Baldwin e assim por diante, agora podemos dar mais um passo e afirmar que o romance também mobiliza e monta elementos caracterizados por possuírem formas, origens e estilos heteróclitos. E o princípio estilístico do livro, essa montagem de elementos díspares e justapostos em uma estrutura ficcional, é o motivo pelo qual esse romance ocupa, como já dissemos, um lugar particular na história do romance modernista estadunidense.

\footnotetext{
${ }^{104}$ Cf. nota 96 .
} 


\subsection{The center of things: montagem como princípio estilístico}

Três anos após a publicação de Manhattan Transfer, em 1928, Dos Passos viajou para a Rússia, onde conheceu Sergei Eisenstein e Dziga Vertov. Foi um momento importante na trajetória do autor, que nos anos 1920 havia se engajado à esquerda, próximo, mas nunca filiado ao Partido Comunista. Nessa década, além de publicar quatro romances, Dos Passos ficou conhecido em dois outros meios: a dramaturgia e o jornalismo. Na dramaturgia, colaborou ativamente com o grupo de teatro experimental New Playwrights, do qual foi também um dos criadores; no jornalismo, por sua vez, ajudou a fundar a New Masses, de cuja comissão editorial participou - uma revista de posicionamento político à esquerda que reivindicava para si a tradição da extinta Masses, proibida por ordem de Woodrow Wilson durante a Primeira Guerra Mundial. Foi como jornalista que, em 1926, Dos Passos primeiro conheceu o caso de dois imigrantes italianos condenados à morte, Nicola Sacco e Bartolomeo Vanzetti. Os dois anarquistas haviam sido presos em Boston sob acusação de participação em um roubo seguido de assassinato e foram julgados em um processo duvidoso, em que a sua posição política e origem estrangeira penderam a balança contra ambos, não obstante a ausência de provas, o que, por fim, rendeu-lhes a pena capital. A execução ocorreu em 1927, a despeito da atenção internacional que o caso recebeu e da mobilização de importantes artistas, dentre os quais Dos Passos, convocado pelas revistas com as quais contribuía para cobrir o julgamento, entrevistar os condenados e escrever artigos discutindo as suas impressões e descobertas. Convencido da inocência dos dois italianos, Dos Passos participou ativamente de manifestações que exigiam uma revisão do julgamento, foi preso em uma delas e, depois, publicou o panfleto Facing the Chair ${ }^{105}$.

Em seu trabalho como dramaturgo junto ao grupo The New Playwrights, o autor considerava fundamental a investigação experimental como uma tentativa importante de desenvolver uma pesquisa capaz de restituir ao teatro a sua função social. Não se tratava exatamente de produzir algum resultado político imediato ${ }^{106}$, mas Dos Passos acreditava na necessidade de superar não só a "competição" com o

\footnotetext{
${ }^{105}$ Sobre a participação de Dos Passos nas organizações contra a condenação de Sacco e Vanzetti, ver BÉJA, Alice. Dos Passos and the Sacco-Vanzetti case: a genealogy of politics and fiction. In: ABREU, Maria Zinia Gonçalves; VASCONCELOS, Bernardo Guido (Eds.). John Dos Passos. Biography and critical essays. Newcastle Upon Tyne: Cambridge Scholars Publishing, 2010, p. 63-70.

${ }^{106}$ DOS PASSOS, John. Did the New Playwrights Theatre Fail? (1929). In: PIZER, Donald (Org.). John Dos Passos: the major nonfictional prose. Detroit: Wayne State University Press, 1988, p. 118.
} 
cinema e o rádio, que colocava a existência do teatro em perigo, mas também de enfrentar certa cultura do espetáculo ${ }^{107}$, à qual se opunha e que pretendia enfrentar ${ }^{108}$. Após alguns sucessos parciais e muitos fracassos, quando o seu grupo parecia em vias concretas de fechar as portas, Dos Passos decidiu viajar para a União Soviética e investigar as perspectivas do teatro então desenvolvidas em Leningrado e Moscou ${ }^{109}$. Em uma carta a seu grande amigo desde a época da faculdade em Harvard, e. e. cummings, o autor relatou que a parte mais interessante da viagem fora o seu encontro com os diretores do cinema soviético ${ }^{110}$, Sergei Eisenstein, Pudovkin e Dziga Vertov. Em textos posteriores, ele sempre enfatizou a importância da conversa que teve durante essa viagem com Eisenstein, em que ambos discutiram sobre as concepções teóricas do diretor soviético e "concordaram plenamente no que diz respeito à importância da montagem"111.

Muito foi especulado sobre a possível influência dos filmes de Eisenstein na escrita de Manhattan Transfer. Em uma entrevista sobre a relação entre a montagem no cinema e o arcabouço formal do romance, Dos Passos relatou que provavelmente viu The birth of a nation (filme de D. W. Griffith, lançado em 1915), "uma das primeiras tentativas de montagem", mas que, à época da produção do romance publicado em 1925, não tinha certeza de ter visto algum filme de Eisenstein ${ }^{112}$. É realmente improvável que ele tenha assistido qualquer filme do diretor soviético antes de completar Manhattan Transfer, já que as produções de Eisenstein tiverem uma distribuição muito reduzida nos Estados Unidos e Potemkin, o primeiro de seus filmes a ser exibido no cinema norte-americano, foi lançado apenas em 1926, um ano depois

\footnotetext{
${ }^{107}$ DOS PASSOS, John. Travel books \& other writings, cit., p. 591-595.

${ }^{108}$ DOS PASSOS, John. They Want Ritzy Art. In: PIZER, Donald (Org.). John Dos Passos: the major nonfictional prose. Detroit: Wayne State University Press, 1988, p. 112-114.

109 "Sacco and Vanzetti were dead. The New Playwrights' Theatre, though not quite on the rocks, was proving to be one headache after another. Administration and money raising just weren't my dish. It occurred to me this might be a good time to visit the Soviet Union. There wasn't much sense in going just for the trip, but studying the Russian theatre, obviously in its heyday, would be helpful in planning new productions, and might give me sidelights on how people lived in a socialist society." DOS PASSOS, John. The best times. New York: The New American Library, 1966, p. 173. Ver também DOS PASSOS, John. Looking back on U.S.A (1959). In: PIZER, Donald (Org.). John Dos Passos: the major nonfictional prose. Detroit: Wayne State University Press, 1988, p. 236.

${ }^{110}$ SEED, David. Cinematic fictions. Liverpool: Liverpool University Press, 2009, p. 137; DOS PASSOS, John. The best times, cit., p. 180.

${ }^{111}$ DOS PASSOS, John. The best times, cit., p. 180. Ver também LOWRY, E. D. The Lively Art of Manhattan Transfer. PMLA, v. 84, n. 6, p. 1.636, Oct. 1969. Disponível em: < http://www.jstor.org/ stable/1261510>. Acesso em: 14 dez. 2014.

${ }^{112}$ DOS PASSOS, John. John Dos Passos - interview by David Sander (1962). In: PIZER, Donald (Org.). John Dos Passos: the major nonfictional prose. Detroit: Wayne State University Press, 1988, p. 247.
} 
de os manuscritos do romance terem sido entregues à editora ${ }^{113}$. Tampouco é provável que a teoria de Eisenstein tenha chegado a ele nessa época, já que os seus artigos começaram a ser publicados em inglês apenas a partir de $1927^{114}$.

Embora não tenha tido contato com a obra ou a discussão teórica de Eisenstein antes da escrita de Manhattan Transfer, Dos Passos estava inserido em círculos relacionados à arte modernista e de vanguarda. Além de ter estudado arquitetura, ele era ilustrador, desenhou o pano de fundo de algumas peças de teatro e pintava sobretudo aquarelas. Por intermédio de seus amigos Sarah e Gerald Murphy, Dos Passos colaborou na preparação do cenário para a apresentação de Les noces, de Igor Stravinsky ${ }^{115}$, e conheceu pintores como Fernand Léger - seu pintor cubista preferido -, Picasso e Juan Gris ${ }^{116}$, para citar apenas alguns dos artistas com os quais ele travou contato e que participavam do que ele chamou de "barricadas cubistas"117:

Os futuristas italianos, os franceses da escola de Rimbaud, os poetas que acompanharam o cubismo na pintura estavam tentando produzir algo que saltasse da página. Simultaneidade, como o denominavam. Isso me estimulava.

Por que não escrever uma crônica simultânea? Um romance cheio de instantâneos da vida como um filme documental. (...)

Eu sonhava em usar tudo que havia aprendido com todos esses métodos para produzir uma crônica satírica do mundo que eu conhecia. Eu sentia que tudo deveria ser incluído: músicas populares, anseios e preconceitos políticos, ideais, esperanças, desilusões, ideias excêntricas, recortes do jornal diário. ${ }^{118}$

\footnotetext{
${ }^{113}$ Em maio de 1925, quando enviou o manuscrito do romance para a editor, Dos Passos publicou um texto sobre teatro em que demonstra uma perspectiva um tanto pessimista sobre a relação entre o cinema e a cultura estadunidense: "A century that has to snatch its hasty life furtively between time clock and alarm clock requires the stimulant of some human externalization, warm and glamorous and passionate, that it misses in the chilly phantasmagoria of the movies or in the slightly curdled strains of radio music". Vale notar que o texto não critica a inovação técnica, mas o papel que o cinema e o rádio têm no cotidiano da cultura estadunidense, isolando ainda mais as pessoas em seus pigeonholes. DOS PASSOS, John. Travel books \& other writings, cit., p. 591.

${ }^{114}$ SPINDLER, Michael. John Dos Passos and the Visual Arts. Journal of American Studies, v. 15, n. 3, Dec. 1981, p. 403.

${ }^{115}$ Embora não tenha participado diretamente, Dos Passos também conversou muito com Murphy sobre a criação do cenário do balé Within the Quota (1923), composto por Cole Porter. LUDINGTON, Townsend. John Dos Passos: a twentieth century odyssey, cit., p. 226.

${ }^{116}$ DOS PASSOS, John. The best times, cit., p. 153.

${ }^{117}$ DOS PASSOS, John. Translator's Foreword to Panama: or, The Adventures of My Seven Uncles (1931). In: PIZER, Donald (Org.). John Dos Passos: the major nonfictional prose. Detroit: Wayne State University Press, 1988, p. 134.

${ }^{118}$ Tradução nossa do original: "The Italian futurists, the Frenchmen of the school of Rimbaud, the poets who went along with cubism in painting were trying to produce something that stood up off the page. Simultaneity, some of them called it. That excited me. Why not write a simultaneous chronicle? A novel full of snapshots of life like a documentary film. (...) I dreamed of using whatever I'd learned from all these methods to produce a satirical chronicle of the world I knew. I felt that everything should go in: popular songs, political aspirations and prejudices, ideals, hopes, delusions, crackpot notions, clippings out of the daily newspaper”. DOS PASSOS, John. Contemporary Chronicles (1961), cit., p. 239. É curioso notar que Dos Passos fala em cinema, mas a sua referência é o documentário, o que nos faz imaginar que ele pode ter em mente Manhatta (1921), de Charles Sheeler e Paul Strand.
} 
Para alcançar o efeito desejado dessa "crônica satírica", uma representação que fosse capaz de captar a sensação de simultaneidade (algo presente no repertório comum das diferentes artes nessa época) e transmitir a impressão de que aquele era o mundo vivido também pelo leitor, fez-se necessário não só se apropriar dos elementos que compunham esse universo urbano mas também descobrir uma técnica capaz de capturar as relações temporais e espaciais que particularizavam a experiência urbana na virada do século XX.

Ao comentar as técnicas narrativas utilizadas no primeiro romance da trilogia U.S.A. - publicado um ano após a viagem para a União Soviética e depois do importante encontro com Eisenstein -, Dos Passos afirmou que, desde o início da escrita, a sua intenção já era desenvolver os procedimentos empregados, "possivelmente de forma inconsciente", no romance anterior, Manhattan Transfer. O termo "inconsciente", que o autor usa em referência à obra de 1925, é importante nesse contexto, pois evidencia que a construção por meio da montagem, como princípio de organização da narrativa, foi uma resposta à necessidade interna dessa matéria. Em vez de optar por uma disposição narrativamente convencional desses materiais díspares, ou seja, de organizá-los de forma a que parecessem subordinados a uma trama principal e a alguns enredos secundários, cronologicamente relacionados e arranjados segundo um nexo de causa e efeito, Dos Passos experimenta artifícios e mecanismos para criar, por exemplo, uma ilusão de simultaneidade, que rompesse a possibilidade de uma sistematização convencional do espaço representado. As partes heterogêneas - as canções, as histórias que representavam as esperanças e desilusões da época, as notícias de jornal -, incumbidas da tarefa de compor esse quadro urbano, ganham autonomia na medida em que são justapostas de forma descontínua, sem uma relação necessariamente motivada pelo texto. Esse princípio de construção, em literatura, é usualmente designado pelo termo montagem e consiste em uma "técnica emergente nas modalidades contemporâneas de representação, onde o fragmento passou a inesperado primeiro plano nas formas de elaboração literária"119.

A montagem organiza, então, toda a estrutura do livro e articula os elementos heterogêneos. Já vimos na concatenação descontínua das tramas e dos episódios, discutida a partir da análise dos primeiros parágrafos do romance, como se dá a aproximação brusca de conteúdos heterogêneos, certamente um dos elementos mais

${ }^{119}$ CARONE, Modesto. Metáfora e montagem. São Paulo: Ed. Perspectiva, 1974, p. 102. 
facilmente identificáveis dentre os muitos que o romance explora. Embora possa ser afirmado que todos os elementos que compõem a obra estão na verdade subordinados ao grande tema da vida na metrópole, cada fragmento introduz um conteúdo expressamente autônomo em relação aos enredos paralelos e aos episódios que interferem em seu desenvolvimento. Vimos também como estilos heterogêneos podem ser completamente diferentes quando comparamos um parágrafo ao seguinte (por exemplo, o parágrafo inicial e os subsequentes).

Não reside, todavia, apenas no conteúdo a heterogeneidade dos materiais. A origem da maior parte do material que compõe o romance é ficcional; contudo, esses enredos paralelos e os episódios isolados ficcionais são intercalados, por sua vez, a materiais de origem não ficcional, como canções populares de teatro, rádio ou ouvidas pela cidade (é o caso da passagem "Glory Glory comes the Army, striding lasses"," refrão entoado pelo Exército da Salvação marchando pela rua), notícias retiradas dos jornais ("Senator 8, Giants 2, Diva Recovers Pealrs, \$ 800,000 robbery"121), anúncios vistos pelas vitrines, placas penduradas em lojas ("Must vacate" ${ }^{122}$ ). Em outras palavras, temos aqui também uma heterogeneidade no que diz respeito à proveniência de diferentes ready-mades. Esses materiais pré-formados, que não foram criados ficcionalmente pelo autor, são produtos feitos em escala industrial, possuem origens diversas e têm um papel destacado na montagem do romance.

4) At a yellowpainted drugstore at the corner of Canal, he stopped and stared abstractedly at a face on a green advertising card. It was a highbrowed cleanshaven distinguished face with arched eyebrows and a bushy neatly trimmed mustache, the face of a man who had money in the bank, poised prosperously above a crisp wing collar and an ample dark cravat. Under it in copybook writing was the signature King C. Gillette. Above his head hovered the motto NO STROPPING NO HONING. The little bearded man pushed his derby back off his sweating brow and looked for a long time into the dollarproud eyes of King C. Gillette. Then he clenched his fists, threw back his shoulders and walked into the drugstore. ${ }^{123}$

Um dos primeiros momentos em que o leitor se depara com um material de origem não ficcional colado ao texto, a cena acima encerra a primeira parte do

\footnotetext{
${ }^{120}$ DOS PASSOS, John. Manhattan Transfer, cit., p. 299.

${ }^{121}$ DOS PASSOS, John. Manhattan Transfer, cit., p. 143

${ }^{122}$ DOS PASSOS, John. Manhattan Transfer, cit., p. 299.

123 "Numa farmácia amarela na esquina da Canal, ele parou e fitou absortamente o rosto no cartaz verde da propaganda. Era um rosto sofisticado, barbeado, distinto com sobrancelhas arqueadas e um bigode vasto e bem aparado, o rosto de um homem que tinha dinheiro na conta, disposto prosperamente sobre um colarinho elegante e um amplo plastrão preto. Abaixo, escrito em bela caligrafia, estava a assinatura do King C. Gillette. Sobre sua cabeça flutuava o lema SEM AMOLAR SEM AFIAR. O baixinho barbudo tirou o chapéu coco de sua testa suada e ficou olhando por um tempo para os olhos orgulhosamente ricos do King C. Gillette. Ele então cerrou os punhos, jogou os ombros pra trás e entrou na farmácia.” [Tradução nossa.] DOS PASSOS, John. Manhattan Transfer, cit., p. 9.
} 
romance e apresenta um judeu caminhando por uma região degradada do sul da ilha de Manhattan, passando entre cortiços até encontrar uma propaganda na vitrine de uma farmácia ${ }^{124}$. O trecho introduz de forma indireta uma propaganda muito conhecida na virada do século, cuja imagem o leitor da década de 1920 provavelmente conseguia reconstituir com clareza (Figura 1). Por ser uma descrição feita pelo narrador a partir de um centro de consciência específico (a personagem do judeu), trata-se de uma introdução indireta e, literariamente, convencional de um material capturado diretamente do cotidiano imediato da cidade ${ }^{125}$. Vale notar que esse centro de consciência, do qual depende o ponto de vista, é uma personagem anônima, em contraste direto com o nome sempre reiterado do produto anunciado ${ }^{126}$.

Nesse trecho, interessa-nos em particular o fato de que a representação indireta oferece ao leitor um detalhe singular: o destaque gráfico conferido ao "lema" ("No stropping no honning”), simulando as letras garrafais que pairam acima da imagem do King C. Gillette na propaganda.

\footnotetext{
${ }^{124}$ Essa cena já foi comentada em textos como: SEED, David. Cinematic fictions, cit., p. 133; GOODSON, A.C. Manhattan Transfer and the metropolitan subject. Arizona Quarterly: a journal of American literature, culture, and theory, v. 56, n. 1, p. 100, Spring 2000; GEYH, Paula. From Cities of Things to Cities of Signs: Urban Spaces and Urban Subjects in Sister Carrie and Manhattan Transfer. Twentieth Century Literature, v. 52, n. 4, p. 428, Winter 2006.

${ }^{125}$ Embora tenha elaborado a ideia do produto descartável em 1895, a lâmina de barbear descartável apenas surgiu no mercado em 1901 e é só em 1905 que o mote "No Stropping No Honing" se torna amplamente difundido e faz parte da vida cotidiana dos consumidores. Ver SLADE, Giles. Made to break: technology and obsolescence in America. Cambridge: Harvard University Press, 2006, p. 15-17. ${ }^{126}$ SEED, David. Cinematic fictions, cit., p. 133.
} 


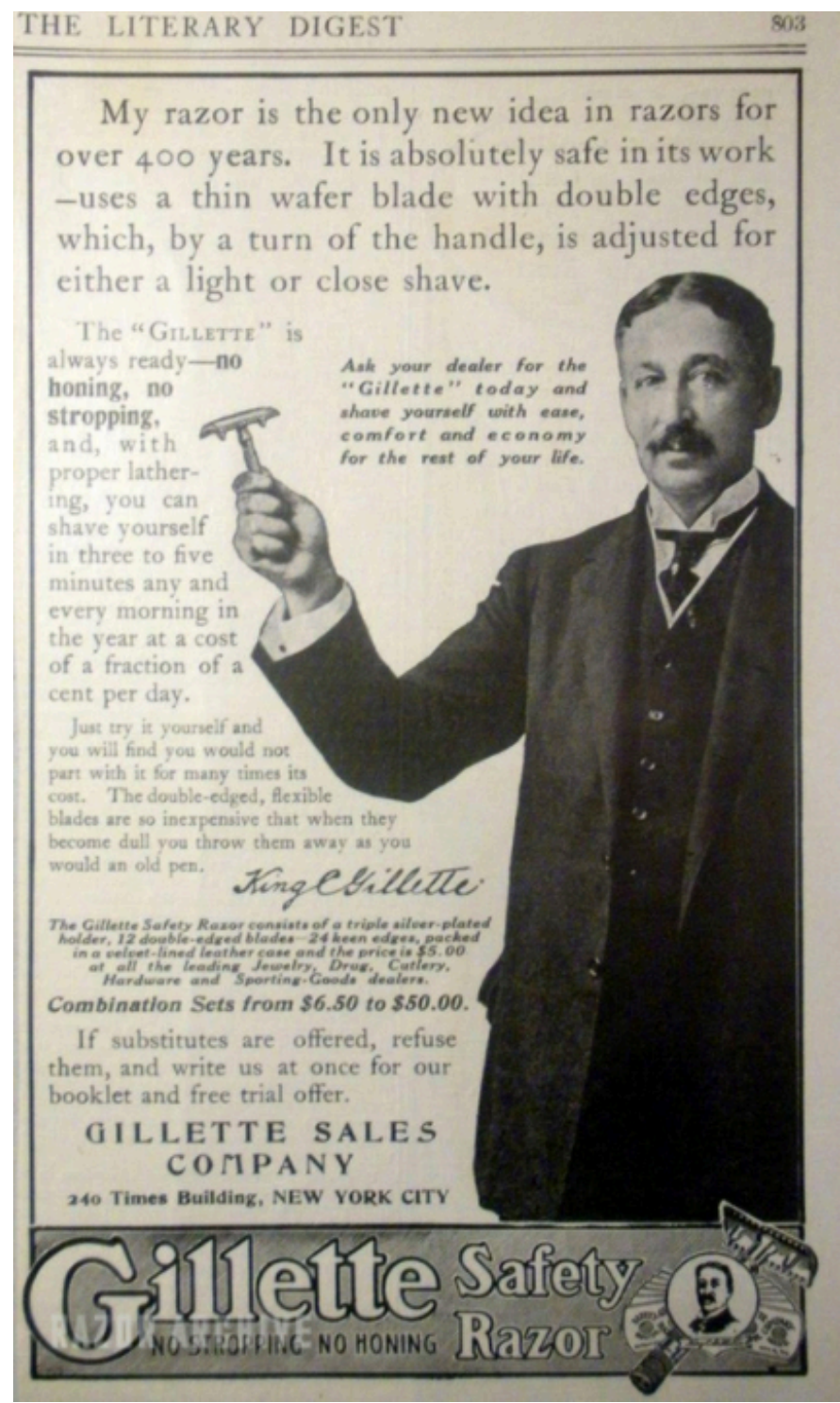

Figura 1 - Imagem disponível no Razor Archive ${ }^{127}$.

Provavelmente a propaganda trazia algo similar a essa imagem.

\subsection{A city of scrambled alphabets: colagem}

5) His eyes fell on the headline on a Journal that lay on the floor by the coalscuttle where he had dropped it to run for the hack to take Susie to the hospital.

MORTON SIGNS THE GREATER NEW YORKER BILL

COMPLETES THE ACT MAKING NEW YORK WORLD'S SECOND METROPOLIS ${ }^{128}$

\footnotetext{
${ }^{127}$ Disponível em: <http://www.razorarchive.com/p120963519>. Acesso em: 16 jan. 2016.

128 "Seus olhos deitaram-se sobre a manchete de um jornal que estava no chão ao lado do baldedecarvão onde ele havia jogado antes de correr para pegar o táxi e levar Susie ao hospital. MORTON ASSINA O PROJETO DE LEI DA GRANDE NOVA YORK COMPLETA O ATO QUE FAZ DE NOVA YORK A SEGUNDA MAIOR METRÓPOLE DO MUNDO.” [Tradução nossa.] DOS PASSOS, John. Manhattan Transfer, cit., p. 11.
} 
Assim como no caso da propaganda da Gillette, o que primeiro chama a atenção do leitor neste quinto trecho (Figura 2) é a alteração do arranjo tipográfico do texto. Escrito em caixa alta e disposto no centro da página, o segmento transcrito simula a manchete de jornal também pela reprodução da sintaxe truncada, limitada pelo espaço predefinido das páginas do periódico e pela convenção da manchete. De forma similar ao que ocorre a partir do corte abrupto na concatenação de episódios, o procedimento cria mais uma perturbação no desenvolvimento narrativo ao romper, em primeiro lugar, a disposição gráfica; em segundo, o estilo de narração, com o qual o leitor já está habituado e que é substituído pelo discurso jornalístico. O expediente, como aparece nesse momento, não é excepcional. Outros romances já haviam se apropriado de textos de forma mais ou menos semelhante e não é preciso ir muito longe para encontrar exemplos. No romance Babbitt, publicado em 1922 por Sinclair Lewis, vemos uma série de trechos como esse:

Yuh, but Dad, they just teach a lot of old junk that isn't any practical use--except the manual training and typewriting and basketball and dancing--and in these correspondence-courses, gee, you can get all kinds of stuff that would come in handy. Say, listen to this one:

\title{
'CAN YOU PLAY A MAN'S PART?
}

\begin{abstract}
'If you are walking with your mother, sister or best girl and some one passes a slighting remark or uses improper language, won't you be ashamed if you can't take her part? Well, can you?

'We teach boxing and self-defense by mail. Many pupils have written saying that after a few lessons they've outboxed bigger and heavier opponents. The lessons start with simple movements ... ${ }^{, 129}$
\end{abstract}

No caso do romance de Sinclair Lewis, essas alterações tipográficas têm como objetivo representar um anúncio lido em jornal. A propaganda é, afinal, um dos grandes temas do romance de Lewis, que faz da personagem principal, Babbitt, um autoaclamado "exímio" escritor de propagandas. A diferença essencial em relação a Dos Passos é a de que esses elementos são criados ficcionalmente pelo próprio Lewis e não remetem a datas ou acontecimentos públicos. Dizem respeito evidente e imediato ao que está sendo tematizado no enredo. Ou seja, a técnica serve para reproduzir a forma do jornal e o conteúdo de um tipo de propaganda muito comum na época, de cursos por correspondência. Em Babbitt, cuja trama se situa na década de 1920, quando as agências de publicidade expandiram e o mercado dos anúncios na

${ }^{129}$ LEWIS, Sinclair. Babbitt. Mineola: Dover Thrift Editions, 2003, p. 62. 
imprensa ganhava força, o romance tematiza a importância da propaganda e do jornal no desenvolvimento das relações pessoais, na criação de expectativas e de frustrações.

Há também algumas coincidências na utilização dos anúncios ou das notícias de jornal nos dois romances. Em primeiro lugar, ambos remetem à circulação cotidiana desse meio de comunicação, o jornal. Além disso, como no caso de Babitt, em Manhattan Transfer a inserção do recorte é explicada textualmente: Ed lê o jornal do dia e é onde encontra a notícia reproduzida; o leitor vê a notícia porque a personagem a vê.

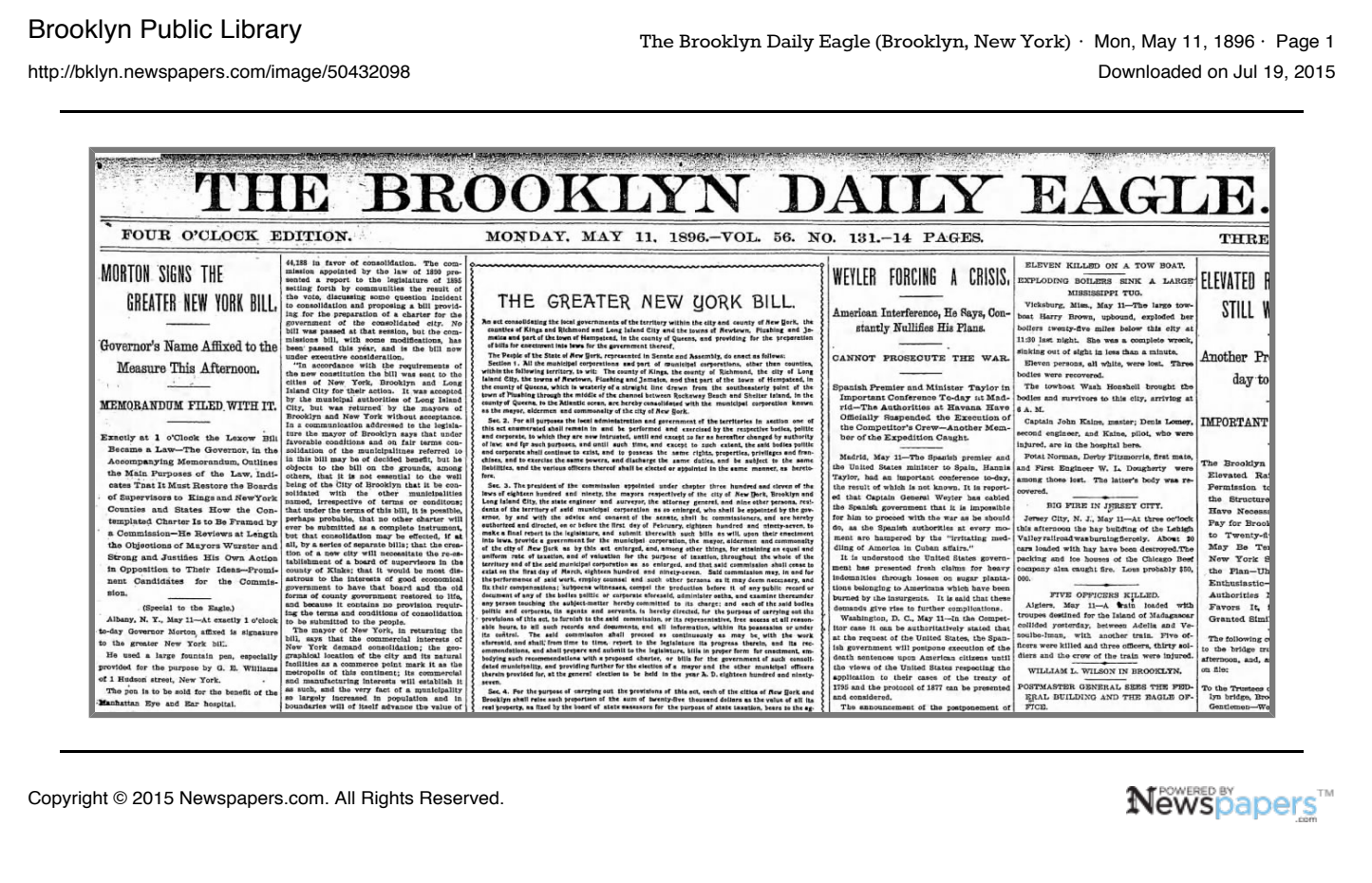

Figura $2^{130}$ - Manchete utilizada por Dos Passos

(não necessariamente retirada desse jornal).

O resultado formal, no caso do romance de Dos Passos, é completamente diferente do que foi feito antes, seja em Babbitt ou em outros romances. Comparado ao que vimos em Sinclair Lewis, destaca-se o fato de que a notícia estampada em

\footnotetext{
${ }^{130}$ Manchete publicada no periódico The Brooklyn Daily News, 11 de maio de 1896. A notícia pode ser conferida no site da Biblioteca Pública do Brooklyn. Disponível em: <http://bklyn.newspapers.com/ newspage/50432098/>. Acesso em: 19 jul. 2015.
} 
Manhattan Transfer não é uma tentativa de escrever à maneira de um jornal, mas, sim, a simulação literária do recorte de uma manchete real. Além disso, dois aspectos fazem com que o uso desse procedimento em Manhattan Transfer seja inovador: em primeiro lugar porque esse mecanismo está inserido em uma estrutura narrativa em que a descontinuidade e a heterogeneidade são radicalizadas no conjunto do texto. Em outros termos, a ruptura na colagem da notícia não representa um momento particular do andamento da trama, mas um processo que caracteriza a obra. Em segundo lugar porque, no caso de Dos Passos, esse expediente remete o leitor à realidade extraficcional: trata-se de uma manchete real, de um acontecimento passível de ser situado cronologicamente e que alude a um momento específico da história. E justamente por isso, o material colado exige duas leituras: uma quanto à sua relação com o texto ficcional no qual está inserido e outra relativa à sua inserção em seu suporte original (o jornal). Nessa medida, a colagem nunca "suprime por completo sua alteridade" ${ }^{\prime 131}$. Ela carrega a alteridade para dentro da obra ficcional.

Talvez um dos efeitos mais significativos desse expediente tenha sido a introdução de um repertório compartilhado de vivências cotidianas. Assim como nas colagens cubistas de George Braque ou de Pablo Picasso são introduzidos elementos do dia a dia, como botões e recortes de pano, as notícias de jornal, as canções populares e as propagandas, mobilizadas pelo romance de Dos Passos, tinham ressonância junto ao público leitor da época e se assemelham aos materiais utilizados posteriormente em Berlin Alexanderplatz (1929). Em sua resenha de 1930 sobre o romance alemão, Walter Benjamin elogia o uso desses "documentos" no livro de Alfred Döblin e avalia que o material manipulado por esse tipo de procedimento não pode ser aleatório, mas deve representar um "documento" do cotidiano:

\begin{abstract}
O princípio estilístico do livro é a montagem. Material impresso de toda ordem, de origem pequeno-burguesa, histórias escandalosas, acidentes, sensações de 1928, canções populares e anúncios enxameiam nesse texto. A montagem faz explodir o "romance", estrutural e estilisticamente, e abre novas possibilidades, de caráter épico. Principalmente na forma. O material da montagem está longe de ser arbitrário. A verdadeira montagem se baseia no documento ${ }^{132}$.
\end{abstract}

Para Benjamin, uma das grandes forças de Berlin Alexanderplatz reside na apropriação, dentro de sua estrutura ficcional, do elemento documental. O crítico

\footnotetext{
131 DUBOIS, Jacques; DUBOIS, Philppe; EDELINE, Francis; KLINKENBERG, Jean-Marie; MINGUET, Phillippe. Douze Bribes pour decoller (en 40.000 lignes). Collages, Revue d'Esthétique, Paris: Union Genérale d'Editions, n. 3-4., p. 34-35, 1978.

${ }^{132}$ BENJAMIN, Walter. A crise do romance. Sobre Alexanderplatz, de Döblin. In: Magia e técnica, arte e politica: ensaios sobre literatura e história da cultura. São Paulo: Brasiliense, 1994, p. 56.
} 
indica um processo importante nas discussões sobre a arte modernista e, principalmente, sobre as vanguardas artísticas: no limite, trata-se da recuperação, para o centro da obra, da própria vida. Ainda segundo Benjamin, também o dadaísmo que embora não constituísse um grupo coeso em torno de características estilísticas compartilhadas, podia ser caracterizado por uma "luta fanática contra a obra de arte" havia congregado, para essa luta, as forças dos materiais documentais, colocando "a seu serviço a vida cotidiana".

\subsubsection{A colagem como um procedimento experimental}

No caso de Manhattan Transfer, apropriar-se desses objetos textuais na tessitura da obra era um dos mecanismos em operação para convidar o leitor a identificar a cidade narrada no romance com a sua experiência urbana concreta. $\mathrm{O}$ resultado mais imediato desse procedimento é algo que podemos caracterizar a princípio como um "choque" gerado pela interrupção da narrativa, a qual decorre da quebra da expectativa de um encadeamento convencional dos segmentos. Em vez de a notícia do jornal ser incorporada por meio do discurso indireto livre ["His eyes fell on the headline (...) Just imagine, the world's second metropolis...”], pelo discurso direto ("And he thought how now that New York was considered the world's second metropolis...”) ou ainda pela encenação de um diálogo, ela é destacada no centro da página, mantendo a sua tipografia e sintaxe como se fosse realmente colada ao papel. Contudo, embora o efeito mais imediato remeta à ideia de choque e, portanto, de distanciamento, como programa, o efeito almejado parecia ser de reforçar ou reformular certo projeto ilusionista do realismo formal ao tentar confundir a experiência do texto com uma experiência real. Se, por um lado, esse efeito se perde com o decorrer das décadas e o consequente enfraquecimento das referências claras; por outro, tanto o choque gerado pela ruptura narrativa e pela autonomia das partes quanto a sugestão de uma referência à esfera extraliterária ainda se mantêm.

Este expediente literário, a colagem pontual de materiais originalmente exteriores ao texto ficcional, é parte do princípio estilístico previamente abordado, a montagem. Como ressalta D. Bablet, os dois termos - montagem e colagem designam, em primeiro lugar "um procedimento técnico"; em segundo lugar, "um 
processo criativo"; e, por fim, "o resultado do trabalho realizado: o produto"133. Como ferramenta de análise para o presente estudo, é fundamental distinguir entre os dois procedimentos - distinção esta que não é evidente, pois diferentes críticos adotam perspectivas diversas e até opostas ${ }^{134}$. Para a análise do romance de Dos Passos, a macroestrutura do texto será designada como montagem: concatenação de elementos heterogêneos, por vezes francamente contrastantes, sem que haja a utilização de expedientes narrativos para escamotear as fissuras e a artificialidade da operação. Um, mas não o único, desses elementos são os fragmentos colados, como o jornal. Designação que se refere tanto a um procedimento quanto ao resultado artístico, a colagem foi uma "inovação formal revolucionária" na esfera do cubismo e, portanto, de toda a representação artística do século $X^{135}$. É com os papiers collés de Georges Braque e Pablo Picasso, elaborados a partir de 1912, que se inicia a maior parte dos estudos sobre a prática da colagem na arte moderna, embora mesmo essa origem não seja um consenso. Louis Aragon, por exemplo, que publicou textos de referência sobre a colagem, reivindicava a filiação da colagem moderna às obras de Max Ernst. Sem nos aprofundarmos na discussão acerca da genealogia da técnica que Dos Passos usa, importa-nos, antes, analisar o seu caráter mais geral: a transferência de materiais de um contexto a outro como parte integrante, e não de modo meramente ilustrativo, conservando as suas particularidades originais de maneira que a sua heterogeneidade seja reconhecida ${ }^{136}$. Dito de outro modo, a "decupagem" de um elemento de um suporte textual "pré-formado" e utilizado em um novo elemento com "rupturas internas" "137. Uma vez introduzidos, esses materiais "mantêm a sua alteridade, mesmo que essa alteridade esteja subordinada ao arranjo composicional do todo" ${ }^{\text {"138. A }}$ utilização do termo colagem tem como objetivo justamente tornar explícita a particularidade de que a procedência desses pequenos pedaços é a matéria real histórica, escombros da contínua construção da cidade:

Outro fenômeno reconhecido normalmente como montagem em literatura é a incorporação, ao texto, de trechos provenientes de outras fontes - citações que

\footnotetext{
${ }^{133}$ BABLET, D. Exposé Introductif. In: BABLET, D. (Org.). Collage et montage au théâtre et dans les autres arts durant les années vingt. Lausanne: La Cité; L'Âge d'Homme, 1978, p. 10.

${ }^{134}$ Ver BABLET, D. Exposé Introductif, cit., p. 13.

${ }^{135}$ ULMER, Gregory apud PERLOFF, Marjorie. The futurist moment: avant-garde, avant guerre, and the language of rupture. Chicago: University of Chicago Press, 2003, p. 46.

${ }^{136}$ MOREL, Jean Pierre. Collage, Montage et Roman chez Döblin et Dos Passos. Collages, Revue d'Esthétique, Paris: Union Générale d'Éditions, n. 3-4, p. 47, 1978.

137 DUBOIS, Jacques; DUBOIS, Philppe; EDELINE, Francis; KLINKENBERG, Jean-Marie; MINGUET, Phillippe. Douze Bribes pour decoller (en 40.000 lignes), cit., p. 14.

${ }^{138}$ PERLOFF, Marjorie. The futurist moment..., cit., p. 52.
} 
passam a agir no corpo mesmo do poema, ora como foco de contraste, ora como fator de sustentação semântica, ora realizando simultaneamente os dois desempenhos. (...) Ocorrência, aliás, que se deveria, com mais propriedade, chamar de "colagem", no caso definível como uma espécie de gênero montagem, caracterizada pela apresentação, no texto-base, de elementos estranhos a ele, os quais, embora assimilados ao texto, não perdem os contornos originais dentro do organismo em que se viram de repente introduzidos ${ }^{139}$.

Acreditamos não ser necessário desenvolver uma digressão acerca das diferenças e singularidades da técnica modernista em oposição ao uso da colagem feito em momentos anteriores da história da arte. Há um debate amplo acerca das diferenças do uso de recorte, por exemplo, na arte japonesa do século XII ${ }^{140}$. Ou, ainda, no contexto do romance, das citações ou mecanismos de intertextualidade presentes, como podemos verificar na obra excêntrica de Laurence Sterne, Tristram Shandy, ou das experimentações gráficas dos romances ingleses do século XVIII ${ }^{141}$. Esses debates já foram feitos e acredito que o mais interessante nesse momento seja mostrar de que maneira, na configuração específica desse romance, os materiais préformados são incorporados ao conjunto ficcional do livro e compreender, a partir dessa análise, a sua singularidade. Com base na discussão dos segmentos transcritos a seguir, discutiremos as diferentes formas de colagem elaboradas em Manhattan Transfer.

\subsubsection{O jornal}

No último trecho transcrito (5), o fragmento de notícia de jornal é reproduzido mantendo-se a disposição gráfica original (ou o que poderíamos supor como a disposição gráfica de, digamos, uma manchete de jornal), de forma a explicitar a

\footnotetext{
${ }^{139}$ CARONE, Modesto. Em busca de um conceito de montagem. Discurso, São Paulo, v. 4, n. 4, p. 188, ago. 1973. Disponível em: <http://www.revistas.usp.br/discurso/article/view/37752>. Acesso em: 11 maio 2016.

140 "In this literal sense, collage has been practiced for centuries around the world. But when one examines early 'collages' - for example, twelfth-century Japanese pasted papers (...) - one finds little common ground with the structure of juxtaposition that characterizes a work like Severini's Homage to My Father. Such assemblages as the feather mosaic pictures of Mexico, the Russian icons decorates with geams, pearls, and gold leaf, and especially the lace and paper valentines popular in western Europe and American from the eighteenth century to the present depend for their success on their ability to simulate particular objects". PERLOFF, Marjorie. The futurist moment..., cit., p. 47. Ver também BILLETER, Erika. Collage et montage dans les arts plastiques. In: BABLET, D. (Org.). Collage et montage au théâtre et dans les autres arts durant les années vingt. Lausanne: La Cité ; L'Âge d'Homme, 1978, p. 19-37.

${ }^{141}$ Por exemplo, a inserção de uma partitura musical em Clarissa, de Richardson. Ver BARCHAS, Janine. Graphic design, print culture, and the eighteenth-century novel. Cambridge: Cambridge University Press, 2003, p. 92.
} 
"presença de um material documental heterogêneo"142 em meio ao conteúdo ficcional do enredo. Heterogêneo também no que diz respeito ao estilo que destoa do modo como é composta a voz narrativa. Trata-se do mesmo procedimento mobilizado para reconstituir o lema da Gillette, mas aqui a alteridade do fragmento ganha ainda maior ênfase. Para analisar as particularidades de cada forma de inserção, vamos utilizar a terminologia empregada pelo crítico Jean-Pierre Morel, que se debruçou com muito interesse sobre o uso da montagem e da colagem no romance dos anos 1920 e $1930^{143}$. No trecho de número 4, já brevemente discutido, trata-se, segundo a nomenclatura de Morel, de uma inserção mediada e de motivação implícita, pois o narrador indica que a personagem observa o rosto estampado no anúncio na vitrine da farmácia, de onde se conclui que ela lê também o que nele está escrito. Há, portanto, uma justificação clara, uma motivação, para a representação do lema "NO STROPPING NO HONING". Na passagem seguinte, a colagem também é motivada e, dessa vez, de forma explícita; afinal, o narrador especifica que, ao retornar do hospital em que a sua filha acabou de nascer e recolher do chão um jornal, Ed Thatcher deita os olhos sobre a manchete do dia ("his eyes fell on the headline"). Pode-se dizer, ainda de acordo com Morel, que se trata de uma integração incompleta, já que o texto mantém em larga medida as suas características originais por meio de uma disposição destacada na página.

A colagem então funciona, por um lado, como uma operação de efeito visual, que se distingue tipograficamente do texto-base (ficcional), simulando a fixação na superfície do papel de um recorte concreto colado ao texto. Por outro, também o conteúdo do recorte cria relações diversas com a matéria ficcional. A notícia transmitida pela manchete de jornal original dialoga imediatamente, por exemplo, com o título do capítulo, "Metropolis"; afinal, a reportagem trata da oficialização da reunião das regiões, outrora politicamente distintas, da ilha de Manhattan, Staten Island (também uma ilha), Brooklyn e Queens (ambas na ilha de Long Island) e uma parte do Bronx, fazendo com que Nova York se torne a segunda maior metrópole do mundo (Figura 2) ${ }^{144}$. Dialoga inclusive com o conteúdo individual dos vários

\footnotetext{
${ }^{142}$ MOREL, Jean-Pierre. Montage et collage et discours romanesque dans les années vingt et trente. In: BABLET, Denis (Org.). Collage et montage au théâtre et dans les autres arts durant les anees vingt. Lausanne: La Cité; L'Âge d'Homme, 1978, p. 46.

${ }^{143}$ Ver MOREL, Jean Pierre. Montage et collage et discours romanesque dans les années vingt et trente, cit. e MOREL, Jean-Pierre. Collage, Montage et Roman chez Döblin et Dos Passos, cit.

${ }^{144}$ Para mais informações sobre as controvérsias acerca da consolidação de Nova York e a votação cerrada na região de Brooklyn, ver BURROWS, Edwin G.; WALLACE, Mike. Gotham. A history of
} 
episódios desenvolvidos neste capítulo e que, em alguma medida, dizem respeito às expectativas otimistas do "sonho americano": dialoga, portanto, com os anseios de promoção profissional e crescimento econômico de Ed Thatcher, que contrastam com a região de cortiços em que vive e o incêndio que ele testemunha em seguida à cena de abertura do capítulo. A notícia tem reverberações, da mesma forma, no episódio em que um corretor imobiliário anônimo tenta convencer o Sr. Perry a comprar um terreno no Queens - o argumento utilizado pelo vendedor é justamente de que o crescimento da região estaria garantido pela recente integração da Grande Nova York:

6) Mr Perry flicked at the burdock leaves with his cane. The real-estate agent was pleading in a singsong voice:

'I dont mind telling you, Mr Perry, it's an opportunity not to be missed. You know the old saying sir... opportunity knocks but once on a young man's door. In six months I can virtually guarantee that these lots will have doubled in value. Now that we are a part of New York, the second city in the world, sir, dont forget that... Why the time will come, and I firmly believe that you and I will see it, when bridge after bridge spanning the East River have made Long Island and Manhattan one, when the Borough of Queens will be as much the heart and throbbing center of the great metropolis as is Astor Place today.' (...)

' Poking amid the dry grass and the burdock leaves Mr Perry had moved something with his stick. He stooped and picked up a triangular skull with a pair of spiralfluted horns. 'By gad!' he said. 'That must have been a fine ram. ${ }^{145}$

Nessa cena temos, mais uma vez, uma personagem anônima e uma nomeada artifício que, de início, pode gerar certa confusão para o leitor que ainda espera que as personagens nomeadas retornem ao texto. O Sr. Perry, contudo, faz parte do grupo de "figurantes" que, embora recebam um nome, não reaparecerão. As pontes que vão ligar as ilhas de Long Island e Manhattan, e o fato de que Nova York é a "segunda cidade do mundo" (uma citação quase direta da manchete reproduzida no romance) são a garantia de que os negócios fechados terão sucesso futuro. A cena termina com um indício curioso do progresso: o crânio que Perry encontra remexendo as folhas no terreno indica como toda aquela região ainda era rural e o quanto, nessa "periferia" de

New York City to 1898. New York: Oxford University Press, 1999; e TIERNEY, John. Brooklyn could have been a contender. In: Columbia University Press, 2002 , p. 408.

145 "O Sr. Perry mexeu nas folhas da bardana com sua bengala. O corretor de imóveis estava suplicando numa voz melodiosa: 'Eu não me importo de lhe dizer, Sr. Perry, que é uma oportunidade que não se pode perder. Você conhece o velho ditado, senhor... a oportunidade bate só uma vez na porta de um jovem. Em seis meses eu posso garantir virtualmente que esses lotes vão ter dobrado de valor. Agora que somos parte de Nova York, a segunda maior cidade do mundo, senhor, não se esqueça disso.... Bem, o tempo virá, e eu acredito firmemente que o senhor e eu veremos isso, quando pontes e mais pontes vão cruzar o East River e fazer de Long Island e Manhattan um único lugar, quando o bairro do Queens vai ser o centro pulsante da metrópole como hoje é Astor Place'. (...) Cutucando no meio do mato seco e das folhas de bardana, o Sr. Perry bateu em algo com sua bengala. Ele se inclinou e pegou um crânio com um par de cornos espiralados. "Por Deus!", ele disse. "Esse devia ser um belo carneiro." [Tradução nossa.] DOS PASSOS, John. Manhattan Transfer, cit., p. 13-14. 
Nova York, conviviam a chegada do progresso e os resíduos bastante palpáveis do passado rural - do qual, sintomaticamente, restam apenas os ossos.

A mesma reverberação da manchete se reproduz nas cenas seguintes, por exemplo, na busca de Bud por trabalho e no sonho do namorado anônimo, cuja ascensão econômica pífia alimenta os planos de casamento (prontamente rejeitado por Emily) ${ }^{146}$. A notícia também encontra ressonância nos projetos de sucesso do marinheiro Emile, na cena grotesca do banquete, na compra de um apartamento na Riverside Drive por um jovem casal e no acidente de Gus, que revelará ser a sua grande "vitória".

A representação desse tom otimista, que alimenta os sonhos e planos apresentados nesses episódios, é fundamental, pois “o sonho americano" era uma ideologia muito presente e potente no período descrito pelo livro e também na época em que Dos Passos escreve o romance, entre 1923 e 1925, ou seja, no período anterior à quebra da bolsa de valores. É interessante ver que a cidade de Nova York aparece como "a terra das oportunidades" 147 já em 1670, quando Daniel Denton visita o Novo Mundo e escreve:

I may say, \& say truly, that if there be any terrestrial happiness to be had by people of all ranks, specially of an inferior rank, it must certainly be here: here any one may furnish himself with land, \& live rent-free ${ }^{148}$.

No romance de Dos Passos, esse otimismo está associado ao crescimento que a cidade vinha experimentando (processo que aparece condensado na notícia de jornal), mas também a um mito que acompanha o próprio desenvolvimento dos Estados Unidos como nação - daí a importância de sua representação no romance.

Esse conteúdo otimista, todavia, é contrariado de diferentes formas na narrativa. Nesse segundo capítulo, especificamente, as suas contradições ficam claras quando o otimismo é seguido de algum dado narrativo ou episódio que indica os seus limites reais. Já vimos como o Sr. Perry desenterra um crânio de carneiro no solo do progresso. A cena de Ed Thatcher, que abre o capítulo, é exemplar nesse sentido. Logo após ler a promissora notícia de que a região passa a ser a segunda maior metrópole do mundo (como se esse fato influenciasse, necessariamente para melhor, a vida de cada um de seus habitantes), Ed perde-se em um longo devaneio:

7) Breathing deep he folded the paper and laid it on the table. The world's second

\footnotetext{
${ }^{146}$ Trecho transcrito na página 53.

${ }^{147}$ Dos Passos diria, anos mais tarde, que se trata do país onde "the average man gets the most break".

${ }^{148}$ DENTON, Daniel. Prosperity in New York, cit., p. 40.
} 
metropolis... And Dad wanted me to stay in his ole fool store in Onteora. Might have if it hadnt been for Susie... Gentlemen tonight that you do me the signal honor of offering me the junior partnership in your firm I want to present to you my little girl, my wife. I owe everything to her.

In the bow he made towards the grate his coat-tails flicked a piece of china off the console beside the bookcase. He made a little clicking noise with his tongue against his teeth as he stooped to pick it up. The head of the blue porcelain Dutch girl had broken off from her body. 'And poor Susie's so fond of her knicknacks. I'd better go to bed.'

In the brick houses and the dingy lamplight and the voices of a group of boys kidding and quarreling on the steps of a house opposite, in the regular firm tread of a policeman, he felt a marching like soldiers, like a sidewheeler going up the Hudson under the Palisades, like an election parade, through long streets towards something tall white full of colonnades and stately. Metropolis. out the word Fire. ${ }^{149}$

The street was suddenly full of running. Somebody out of breath let

Como já foi comentado, Ed Thatcher possui uma tendência a sonhar acordado que é alimentada, aqui, pela sensação de que o crescimento da cidade implicaria a abertura de novas oportunidades de ascensão social. No primeiro trecho, o sonho de sua festa de promoção é limitado fisicamente pela parafernália decorativa de sua casa (afinal, ele "desperta" ao derrubar um bibelô da esposa). No momento seguinte, em que o seu olhar transfigura o espaço da rua, é enquadrado por seu entorno desclassificado, onde cortiços são incendiados, deliberadamente ou não ${ }^{150}$. Isso igualmente acontece nas cenas seguintes desse capítulo, por exemplo, quando as divagações ingênuas do francês Emile, que deixa o seu navio apostando na chance de “tornar-se alguém” em Nova York, são contrapostas não só pela cena grotesca a que seu trabalho precário o condena (observando e servindo o banquete dos ricos, enquanto passa fome e calor) mas também pela narrativa de Congo (humilhado pelo casal que lhe oferece um serviço) e pela experiência desiludida de Marco.

\footnotetext{
149 "Respirando profundamente ele dobrou o jornal e colocou sobre a mesa. A segunda maior metrópole do mundo... E meu pai queria que eu ficasse naquela loja idiota em Onteora. Podia até ter ficado se não fosse pela Susie... Senhores, nessa noite em que os senhores me honram oferecendo a sociedade de sua firma, gostaria de apresentar minha filhinha, minha esposa. Eu devo tudo a ela./Quando se curvou em direção à grade da lareira, a ponta do seu casaco bateu em uma peça de porcelana no aparador ao lado da estante de livros. Ele emitiu um pequeno som de estalo com a língua batendo contra os dentes conforme se inclinou para recolher. A cabeça da pequena holandesa de porcelana azul tinha se separado do corpo. 'E a pobre Susie gosta tanto dos seus enfeites. Melhor ir pra cama.'/ Ele abriu a janela e se inclinou pra fora. Um trem $\mathrm{L}$ passou balançando no fim da rua. Um cheiro de fumaça de carvão pinicou suas narinas. Ele ficou pendurado na janela por um tempo enquanto olhava pra cima e pra baixo na rua. A segunda maior metrópole do mundo. Nas casas de tijolos e nas lâmpadas sombrias e as vozes de meninos brincando e brigando nas escadas da casa da frente, no caminhar firme e regular de um policial, ele sentiu o marchar de soldados, como um barco com rodas de pás subindo o Hudson sob as Palisades, como um desfile eleitoral, por longas ruas em direção a uma coisa branca, alta, cheia de colunatas e imponente. Metrópole./A rua estava de repente cheia de correria. Alguém sem fôlego soltou a palavra Fogo." [Tradução nossa.] DOS PASSOS, John. Manhattan Transfer, cit., p. 11-12. ${ }^{150}$ Há, no romance, o fantasma constante de incendiários que espreitam pelas ruas.
} 
O expediente da colagem reforça essas relações ao justapor as cenas de forma brusca. Ademais, há um paralelismo entre os três primeiros segmentos narrativos desse capítulo. A maior parte das ações ocorre em espaços relativamente públicos: na rua, Ed Thatcher vê um incêndio; em um terreno à venda, o Sr. Perry negocia com um corretor; e em uma barbearia, Bud corta os cabelos e lê as notícias. Além disso, nos três eventos o jornal ocupa um lugar de destaque. Ele une os dois primeiros na medida em que a notícia que Ed lê na manchete de seu jornal ("Morton Signs the greater New York Act”) não só se relaciona ao parágrafo de abertura como é o tema da conversa do Sr. Perry ("New York, the second city in the world, sir"), constituindo um elemento central na cena de Bud. Em um editorial para o Brooklyn Daily Times, Walt Whitman escreveu que a imprensa havia se tornado "a instituição par excellence do dia (...). O jornal se tornou o espelho do mundo, sem olhar para ele ninguém consegue realizar nada" ${ }^{151}$. Conforme vimos em Babbitt, o jornal comunica mais do que as informações e as propagandas. Na verdade, a sua própria lógica e a sua ideologia se impõem por meio de sua ampla difusão. De fato, é impossível tentar compreender um período do século XX sem recorrer a essa grande força de homogeneização do repertório cotidiano. Por exemplo, Cecelia Tich, em sua pesquisa sobre a inserção do discurso técnico e industrial, gerado pelo avanço da tecnologia, na vida cotidiana, recorre a jornais e revistas da época para compreender como essa inserção social se revela na linguagem informativa e no conteúdo das propagandas. O jornal, tornado elemento constitutivo da organização dessas metrópoles da virada do século, por meio da colagem foi trazido como documento bruto para dentro da forma do romance com as mais diversas implicações.

Michael Clark tem razão ao afirmar que o uso dessas "referências" factuais visa proporcionar ao romance certa profundidade histórica, e não exatamente armar uma moldura temporal rígida ${ }^{152}$. Contudo, não há como negar que o aspecto mais singular e específico no uso da manchete é fazer com que o jornal se torne o único elemento que permite ao leitor situar cronologicamente os episódios da narrativa. Para verificar essa hipótese, basta observar o desenvolvimento do primeiro capítulo do

\footnotetext{
151 "Newspaper have become the mirror of the world, without looking into which, no one can accomplish anything." WHITMAN, Walt apud NOVERR, Douglas A.; STACY, Jackson. Introduction. In: NOVERR, Douglas A.; STACY, Jackson (Eds.). Walt Whitman's selected journalism. Iowa: University of Iowa Press, 2015, p. xx.

152 "Clearly, in using these historical references, Dos Passos's primary concern is with providing a historical perspective, a sociological 'depth' to the fictional events, rather than with establishing a 'solid framework."' CLARK, Michael. Dos Passos 's early fiction, 1912-1938, cit., p. 99.
} 
romance: o texto avança sem que um narrador comentador ofereça ao leitor uma data que localize o dia do nascimento de Ellen ou o ano específico da chegada de Bud à cidade. O narrador se distancia o máximo possível do mundo de suas personagens, desaparecendo "por trás da ação que narra" $" 153$ e não fornece qualquer informação que o caracterize como uma voz onisciente, como uma "autoridade artificial" ". Ao contrário, nesse romance as informações devem, via de regra, emergir dos próprios elementos narrados, e o papel do narrador parece restringir-se à seleção dos episódios.

Como resultado dessa construção literária, não há qualquer menção textual a datas nesse primeiro capítulo. Todavia, quando Ed Thatcher retorna da maternidade para casa, no segundo capítulo, e lê a já comentada notícia de jornal, o narrador estrutura a cena de modo a explicitar que aquele é o jornal do dia do nascimento de Ellen - ou seja, é a partir da colagem desse material documental que o leitor tem como saber que o nascimento de Ellen ocorreu no mesmo dia da criação da metrópole de Nova York, em 11 de maio de $1896^{155}$.

O mesmo artifício se repete poucas páginas à frente: Bud, tendo descoberto que é "a aparência que conta" "156 na cidade grande, vai à barbearia, onde começa a ler um jornal. Essa colagem específica simula um passar de olhos sobre o as folhas do periódico, pois transcreve, de forma fragmentada, alguns dos títulos das notícias. Um deles relata um evento importante da batalha Russo-Japonesa: "Relieve from Port Arthur in face of enemies". A partir desse elemento documental, portanto, o romance anuncia um salto cronológico para 1904, sem que haja mediação do narrador ou a inserção de cenas explicativas. Pelo contrário, a primeira leitura do romance normalmente não permite ao leitor perceber que há um descompasso temporal entre as narrativas.

\footnotetext{
${ }^{153}$ ZOLA, Émile. Do romance, cit., p. 98.

${ }^{154}$ BOOTH, Wayne. The rhetoric of fiction. Chicago: The University of Chicago Press, 1983, p. 4.

${ }^{155}$ Há, contudo, um complicador nas contas do romance. Quando, na segunda parte do livro, Ellen está se divorciando de Jojo, em 1914 (nós o sabemos pelas referências à guerra), Ellen lamenta: "Married at eighteen and divorced at twentytwo's a pretty good record". DOS PASSOS, John. Manhattan Transfer, cit., p. 224. A matemática não bate: para que Ellen tenha vinte e dois anos em 1914 seria necessário que tivesse nascido em 1892. Essa discrepância entre as datas pode ter duas explicações possíveis. A primeira, mais interessante, seria a de que a forma do romance desautoriza, de maneira muito capciosa, qualquer fio temporal ou lógica encadeadora que o leitor tente extrair do texto a despeito da ausência de indicações cronológicas por parte do narrador. A segunda, essa mais simples, seria a de uma mera confusão por parte do autor. Embora a primeira fosse mais frutífera, acredito que a segunda seja mais plausível, já que essa inconsistência é um caso único durante todo o romance: em nenhum outro trecho, a trama coloca em questão as datas históricas proporcionadas pela colagem.

156 "It's looks that count in this city." DOS PASSOS, John. Manhattan Transfer, cit., p. 4.
} 
Todavia, o interesse de Bud pelo jornal não é tão aleatório quanto a justaposição dos recortes poderia fazer supor, e a sua atenção recai, por fim, na escandalosa notícia de um matricídio:

8) ADMITS KILLING CRIPPLED MOTHER...

'D'yous mind if I set here a minute an read that paper?' he hears his voice drawling in his pounding ears.

'Go right ahead.'

PARKER'S FRIENDS PROTECT...

The black print squirms before his eyes. Russians... MOB STONES... (Special Dispatch to the Herald) Trenton, NJ

Nathan Sibbetts, fourteen years old, broke down today after two weeks of steady denial of guilt and confessed to the police that he was responsible for the death of his aged and crippled mother, Hannah Sibbetts, after a quarrel in their home at Jacob's Creek, six miles above this city. Tonight he was committed to await the action of the Grand Jury. ${ }^{157}$

Conforme se comentou, a disposição dos fragmentos documentais simula a leitura distraída do jornal: os olhos de Bud passam, negligentes, por uma série de trechos até se deterem sobre a notícia de um assassinato - uma notícia real e a confissão do assassino que Dos Passos insere pouco adiante foi copiada fidedignamente ${ }^{158}$. Trata-se, como na colagem anteriormente discutida, de um caso de motivação explícita (Bud está lendo o jornal) e de inserção incompleta. A relação que a notícia pode sugerir com a história, contudo, é nebulosa e possivelmente passa sem ser notada em uma primeira leitura. Pouco adiante, o leitor descobrirá que Bud assassinou o seu pai - fato já sugerido na barbearia, quando, em vigília, a personagem sonha com um "old man on his back in the potatofield, his beard sticking up lathery withe full of blood”. A construção elaborada por meio do discurso indireto livre permanece vaga, obscura, e não explicita nexos em relação à biografia da personagem.

\footnotetext{
157 “ADMITE TER MATADO A MÃE ALEIJADA./'Você se importa se eu ficar sentado aqui um minuto e ler o jornal?' Ele ouve a sua voz arrastada em suas orelhas latejantes./'Pode ficar.'/OS AMIGOS DE PARKER PROTEGEM.../As letras negras se contorcem na frente dos seus olhos. Russos... MULTIDÃO APEDREJA... (enviado especial do Herald) Trenton, Nova Jersey./Nathan Sibbetts, quatroze anos, confessou hoje depois de duas semanas negando continuamente ser culpado e confessou para a polícia que ele era responsável pela morte de sua mãe idosa e aleijada, Hannah Sibbetts, depois de uma briga em sua casa em Jacob's Creek, seis milhas $(9,6 \mathrm{~km})$ para o norte da cidade. Hoje ele vai receber o veredicto do grande júri." [Tradução nossa.] DOS PASSOS, John. Manhattan Transfer, cit., p. 15.

${ }^{158}$ CARVER, Craig. The Newspaper and Other Sources of Manhattan Transfer. Studies in American Fiction, v. $3, \quad$ n. 2, p. 167-179, Autumn 1975. Disponível em: $<$ https://muse.jhu.edu/article/441271/pdf $>$. Acesso em: 18 jun. 2015.
} 


\subsubsection{A propaganda}

Principalmente por estabelecer uma relação temática com muitos dos enredos paralelos do romance, o jornal se assemelha a outra classe de ready-mades manipulados ficcionalmente: as propagandas e os anúncios recolhidos do espaço público da cidade ${ }^{159}$. Um dado histórico explica a importância inédita, nas últimas décadas do século XIX, que a propaganda adquiriu na configuração concreta da cidade e, consequentemente, em sua figuração literária. $\mathrm{O}$ já corriqueiro hábito de anunciar produtos, escravos foragidos e apresentações teatrais e circenses por meio de cartazes começou a se tornar ainda mais comum: deixando as paredes das tavernas e estalagens, esses anúncios começaram a se espalhar por toda e qualquer superfície, seja do jornal, seja da cidade. Entre 1870 e 1900, nos Estados Unidos, com o aumento da produção industrial em massa, os investimentos dos produtores com propaganda cresceram drasticamente, criando uma verdadeira indústria ${ }^{160}$ movida pelas já existentes agências de publicidade e infiltrando-se na malha do jornal e da cidade. A presença dos anúncios na paisagem urbana tornara-se de tal forma preponderante que era o primeiro aspecto a chamar a atenção dos imigrantes recém-chegados às grandes capitais - surpresa que também caracteriza a chegada de Carrie Mieber quando percorre pela primeira vez as ruas de Chicago no romance Sister Carrie, publicado em 1900 por Theodore Dreiser ${ }^{161}$. A foto a seguir, tirada em 1898 na rua 42 com a Broadway, em Nova York, é um bom exemplo do que deveria ser a experiência de se atravessar as ruas das grandes metrópoles da época.

\footnotetext{
${ }^{159}$ Em uma entrevista de 1968, Frank Gado pergunta se é verdadeira a história de que Dos Passos recortava e guardava manchetes de jornal, ao que o entrevistado respondeu: "I did keep a lot of them. (...) I started doing that quite early in my career. In Manhattan Transfer, I didn't use them directly [como no Jornal da Tela, em USA], but I introduced them to show that I knew more or less what was going on in the world in which my characters lived". DOS PASSOS, John. An interview with John Dos Passos (1968), cit., p. 290.

${ }^{160}$ SHI, David E. Facing facts, cit., p. 93.

161 "A spokesman for the Immigration Protection League commented that foreigners arriving in American cities first noticed 'the pretentiousness of signs and advertisements." SHI, David E. Facing facts, cit., p. 94.
} 


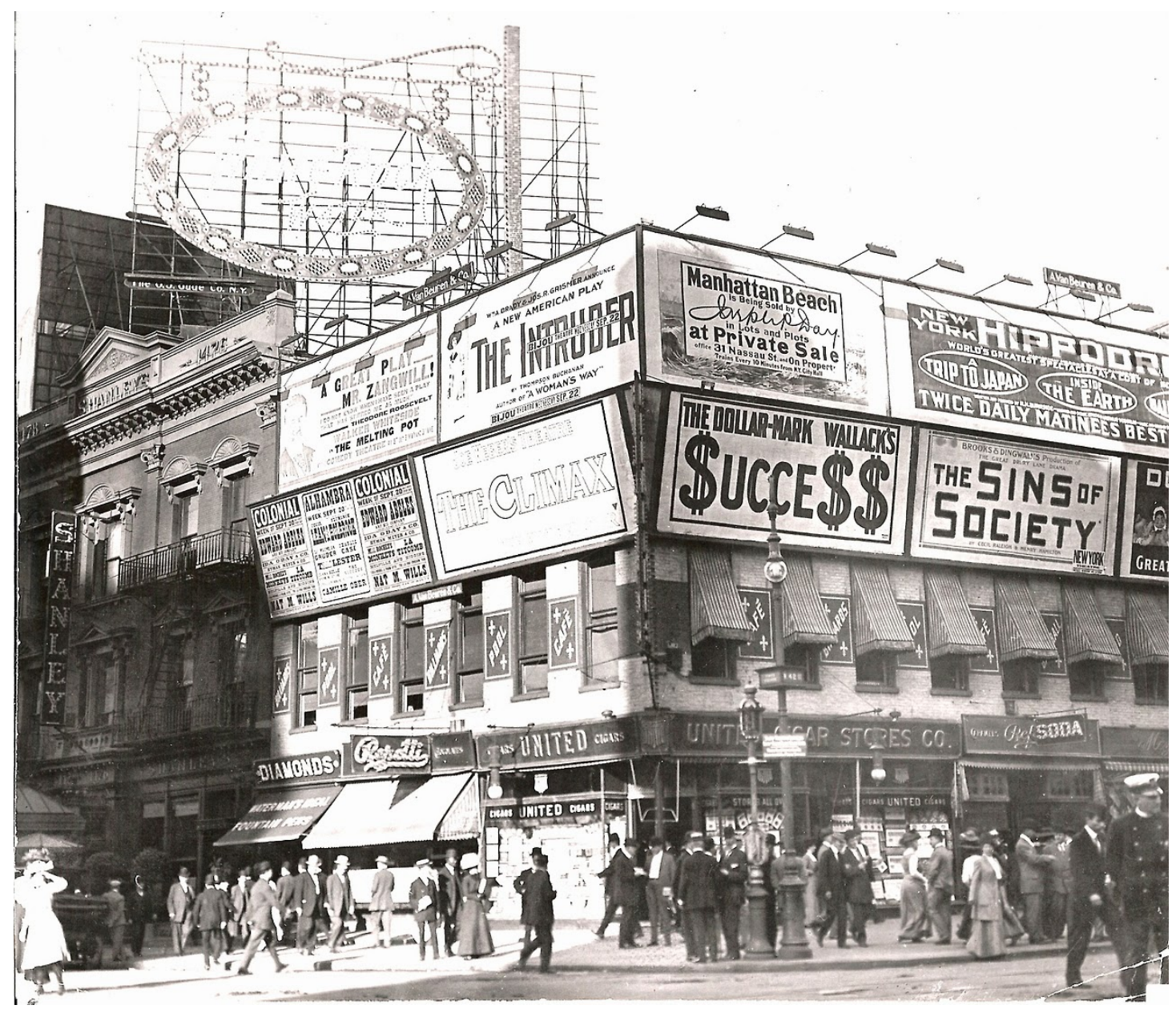

Figura 3 -Times Square por volta de 1909.

No romance de Dos Passos, a propaganda é frequentemente inserida pelos olhos de alguma personagem que lê o jornal ou, principalmente, circula por Manhattan. Em vez de aparecer mediada pelo narrador, que enuncia, por exemplo, em Sister Carrie, que "Havia cartazes numerosos em todos os lugares"162, ela é colada diretamente no texto, perturbando a voz narrativa. Contudo, ela é amiúde introduzida de forma mais ambígua, tal como ocorre no último capítulo do romance, em que Jimmy caminha pela cidade e a montagem de colagens e eventos ficcionais torna-se mais nebulosa:

9) Express service meets the demands of spring. O God to meet the demands of spring. No tins, no sir, but there's rich quality in every mellow pipeful... SOCONY. One taste tells more than a million words. The yellow pencil with the red band. Than a million words, than a million words. 'All right hand over that million... Keep him covered Ben.' The Yonkers gang left him for dead on a

\footnotetext{
162 "Signs where everywhere numerous." DREISER, Theodore. Sister Carrie. New York: Bantam Classic, 2007.
} 
bench in the park. They stuck him up, but all they got was a million words... 'But Jimps I'm so tired of booktalk and the proletariat, cant you understand?' ${ }^{, 63}$.

Assim que pede demissão e deixa o hoje demolido prédio da Pulitzer, Jimmy atravessa as ruas da região do centro comercial da cidade, ao sul da ilha. Caminhando por entre paredes repletas de cartazes e placas, Jimmy observa slogans como o da primeira frase do parágrafo transcrito. A frase é ironizada ("O God to meet the demands of spring") e a ela segue-se uma montagem constituída pelo nome de uma companhia ("Socony"), propagandas de marcas variadas ("No tins, no sir..." - Figura 5; e "One taste tells more than a million words" - Figura 4) e diálogos ("Keep him covered Ben"). Esse é um trecho especialmente interessante, porque a montagem confunde os limites dos diferentes elementos que a compõem. $\mathrm{O}$ roubo sofrido (ou imaginado?) por Jimmy se mistura à propaganda da cerveja ("hand over that million"), à sua experiência de jornalista pobre (afinal, qualquer coisa vale mais do que $\mathrm{um}$ milhão de palavras) e à lembrança amarga da rejeição de Ellen ("But, Jimps I'm so tired of booktalks and the proletariat...").

\footnotetext{
163 "Serviço expresso atende às demandas da primavera. Ai, Deus, atender às demandas da primavera. Nada de lata, não, senhor, mas com uma qualidade intensa a cada doce cachimbada... SOCONY. Um trago diz mais do que mil palavras. O lápis amarelo com a fita vermelha. Do que mil palavras, do que mil palavras. 'Então tá, passa aí o milhar... Fica de olho, Ben.' A gangue de Yonker o deixou pra morrer num banco no parque. Eles o roubaram à mão armada, mas só conseguiram mil palavras... 'Mas, Jimps, estou tão cansada desse papo livresco e do proletariado, você não entende?'” [Tradução nossa.] DOS PASSOS, John. Manhattan Transfer, cit., p. 299.
} 


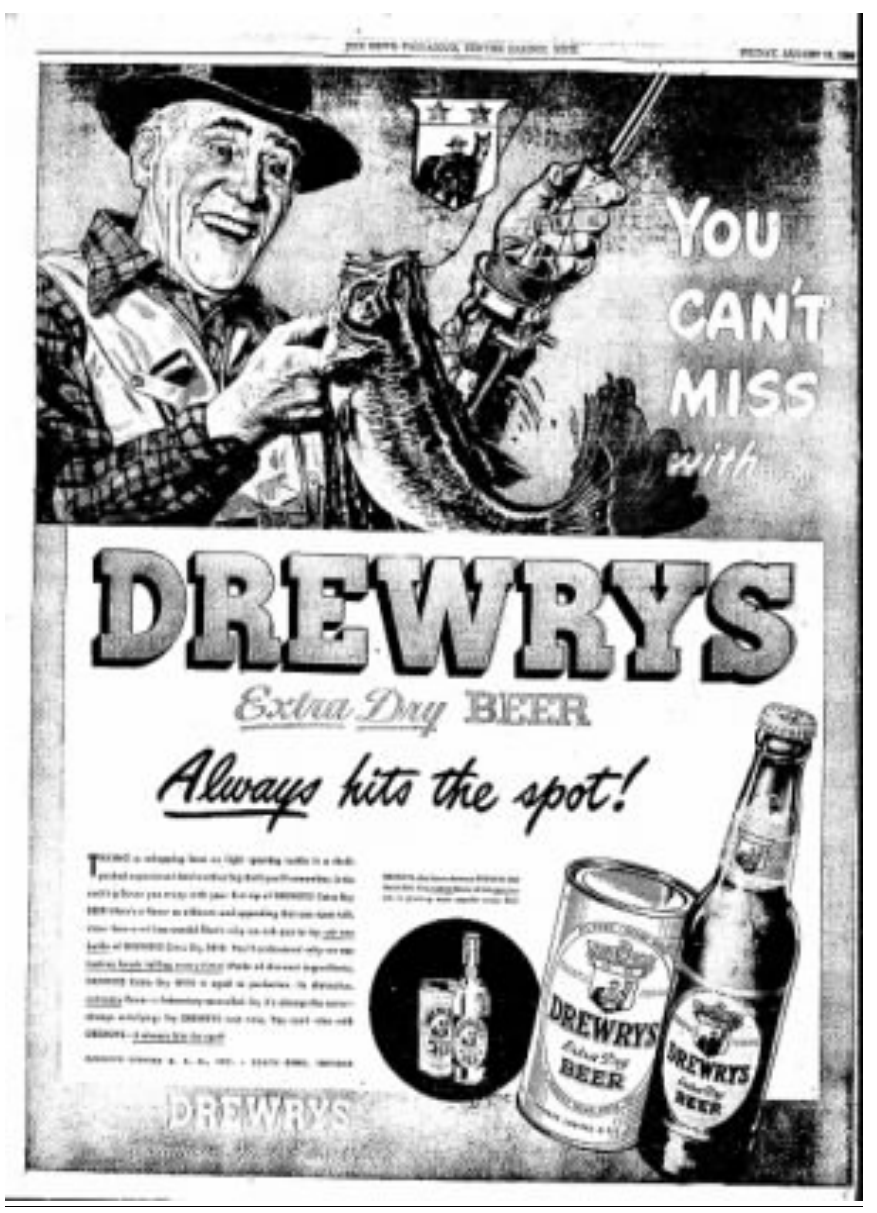

Figura 4 - "Here's a flavor so different and appealing that one taste tells more than a million words!" 


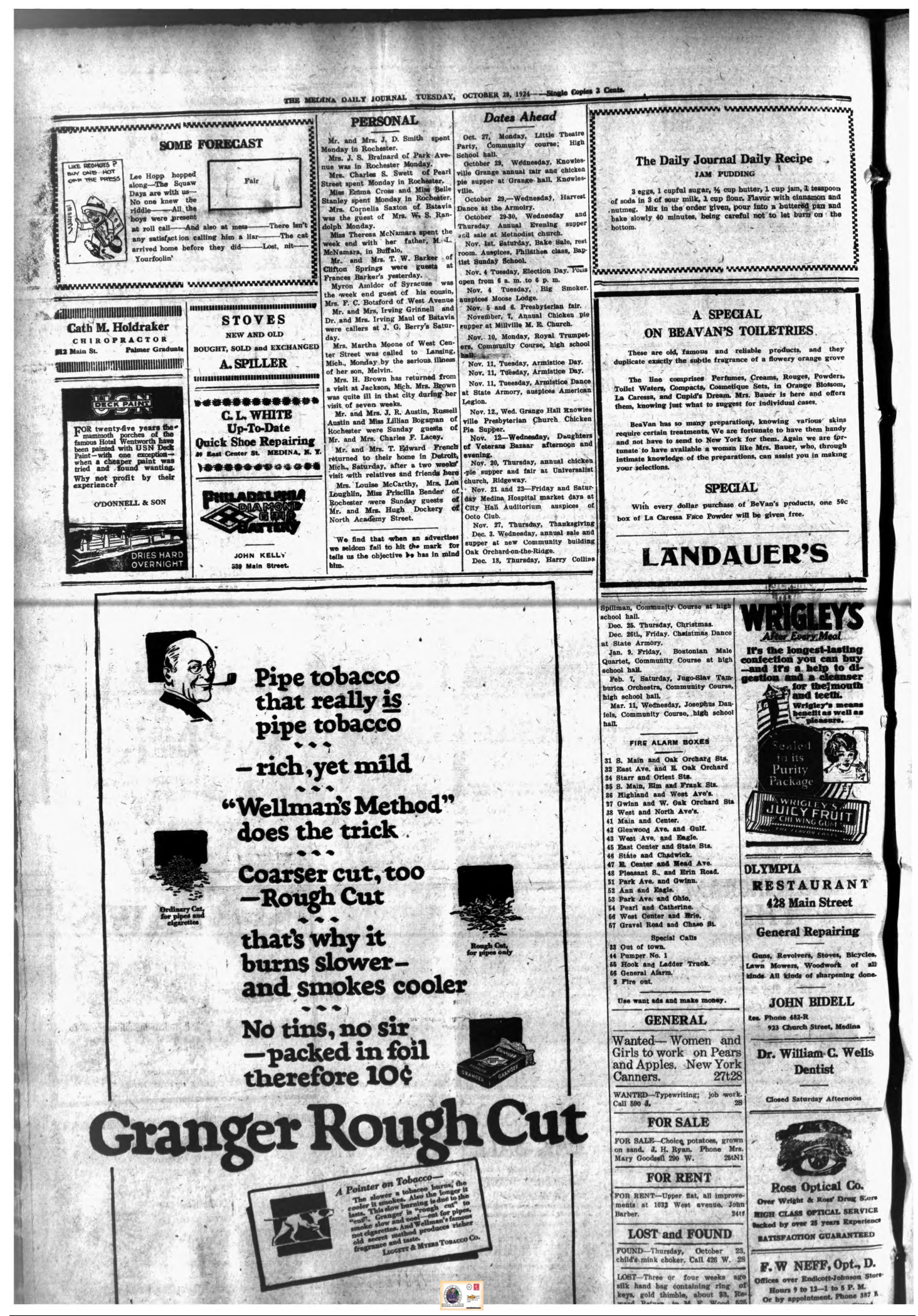

Figura 5-O interessante é que, nessa folha de jornal, além da propaganda de tabaco, já encontramos a propaganda dos chicletes Wrigley’s, que também é apropriada pelo romance e comentaremos mais adiante (Figura 6). 


\subsubsection{Canções populares}

Assim como a montagem mobiliza a indústria da propaganda e o mundo do jornalismo, também as canções populares integram a estrutura do livro - e de formas ainda mais diversas daquelas das propagandas.

10) They had to change at Manhattan Transfer. The thumb of Ellen's new kid glove had split and she kept rubbing it nervously with her forefinger. [...]The wheels rumbled in her head, saying Man-hattan Tran-sfer. Manhattan Tran-sfer. Anyway it was a long time before Atlantic City. By the time we get to Atlantic City... Oh it rained forty days... I'll be feeling gay... And it rained forty nights... I've got to be feeling gay ${ }^{164}$.

O trecho anterior, em que ao discurso indireto livre são justapostos dois versos de uma canção, opera uma fusão entre tipos de enfoque. Ora mais perto, ora mais distante da personagem, o narrador se movimenta com rapidez pela cena. A canção "Longlegged Jack of the Isthmus" aparece aqui fragmentada em dois versos, mas ressurgirá integralmente mais adiante na narrativa. Embora a concatenação de vozes gere certo estranhamento ainda hoje, ou seja, normalmente é preciso reler os trechos para compreender se a voz que enuncia é a da personagem ou a do narrador, os versos são destacados de forma a sublinhar a sua singularidade. Grafados em itálico, os versos evidenciam a sua heterogeneidade ao suporte narrativo no qual está inserido, exigindo que sejam compreendidos como algo distinto da produção ficcional. $O$ romance de Döblin, Berlin Alexanderplatz, publicado alguns anos mais tarde, tem exemplos iluminadores para observarmos como as marcas da heterogeneidade podem ser atenuadas:

Bateu à porta vizinha: "Senhora Priese, fiquei quieta por alguns minutos, tenho de conversar com um cavalheiro. Coisa importante". Pronto, resolvido, pátria amada, podes sossegar, achegue-se ao meu coração, porém você vai para o olho da rua ${ }^{165}$.

Nesse trecho, intercalado ao discurso indireto livre e ao discurso direto, temos o verso não explicitado de uma canção popular, quase um hino nacional extraoficial, o "Die Wacht am Rhein". Sem indicar onde começa e onde termina o verso da canção, o grau de indeterminação é enorme, como ocorre com frequência durante todo o

\footnotetext{
164 "Eles tiveram que baldear em Manhattan Transfer. O dedão da nova luva de pelica tinha rasgado e ela ficava esfregando-o nervosamente com o indicador. (...) As rodas ressoavam na sua cabeça, dizendo Man-hattan Trans-fer. Man-hattan Trans-fer. Enfim, ainda faltava muito até Atlantic City. Quando a gente chegar em Atlantic City... Ah choveu quarenta dias... Eu vou estar feliz... E choveram quarenta noites... Eu preciso estar feliz." [Tradução nossa.] DOS PASSOS, John. Manhattan Transfer, cit., p. 97.

${ }^{165}$ DÖBLIN, Alfred. Berlin Alexanderplatz. São Paulo: Martins Fontes, 2002, p. 35.
} 
romance de Döblin. As propagandas, citações de poemas ou canções se mesclam de maneira imprecisa ao texto. A forma adotada por Dos Passos pode parecer uma simplificação em comparação ao texto de Döblin ${ }^{166}$, mas a sua formulação no romance estadunidense tem efeitos diferentes e complexos.

Ao evidenciar a alteridade dos versos, Dos Passos evidencia que se trata de uma canção, sem simular uma integração nem acentuar possíveis ambiguidades - e nisso reside uma espécie de sobriedade do texto. Nesse caso específico, ao contrário da apropriação das manchetes de jornais, a inserção é não motivada e a integração é incompleta: não motivada porque nada no texto explica a sua necessidade (não sabemos se Ellen ouve esses versos, se os rememora em um momento de aflição ou se os lê em algum meio impresso); incompleta pela já discutida ênfase em sua alteridade por meio da tipografia - o que destaca também a sua heterogeneidade sintática. Contudo, ainda é necessário discutir para que serve essa ênfase.

Assim como as manchetes dos jornais possuem a dupla função de remeter o romance ao mundo cotidiano e de proporcionar uma cronologia às tramas ficcionais, também os efeitos das canções se desdobram no texto. Em 1967, conversando com um pesquisador acerca do uso das canções populares nos "Jornais da Tela" na trilogia U.S.A., Dos Passos comentou que a importância dessa apropriação residia no fato de elas manifestarem um "espírito do tempo"167. Representava igualmente a inserção do que ele classificou como "the common mind" e uma forma de combater a distinção entre "alta" e "baixa" cultura ${ }^{168}$.

Se as notícias remetem o leitor a acontecimentos históricos passíveis de serem situados cronologicamente e as propagandas aludem ao mundo do consumo, que move a economia urbana, de forma similar, a canção reporta o texto ficcional ao cotidiano da metrópole. Na epígrafe no capítulo "Longlegged Jack of the Isthmus", da segunda parte do romance, há uma interessante fusão que pode ajudar a compreender essas relações entre o cotidiano e as canções.

\footnotetext{
166 Justamente pelo fato de as inserções de materiais pré-formados serem motivadas, o crítico Hans Emons afirma que nem Ulysses, nem Manhattan Transfer podem ser considerados verdadeiros romances de montagem. Nesse sentido, Berlin Alexanderplatz, ainda segundo Emons, seria o único romance de montagem da década de 1920. EMONS, Hans. Montage-collage-musik. Berlim: Verlag für wissenschafliche Literatur, 2009, p. 13-14.

${ }^{167}$ DOS PASSOS, John apud TROMBOLD, John. Popular Songs as Revolutionary Culture in John Dos Passos' U.S.A. and Other Early Works. Journal of Modern Literature, v. 19, n. 2, p. 289, Autumn, 1995.

${ }^{168}$ TROMBOLD, John. Popular Songs as Revolutionary Culture in John Dos Passos' U.S.A. and Other Early Works, cit., p. 290.
} 
11) Noon on Union Square. Selling out. Must vacate. WE HAVE MADE A TERRIBLE MISTAKE. Kneeling on the dusty asphalt little boys shine shoes lowshoes tans buttonshoes oxfords. The sun shines like a dandelion on the toe of each new-shined shoe. Right this way buddy, mister miss maam at the back of the store our new line of fancy tweeds highest value lowest price... Gents, misses, ladies, cutrate... WE HAVE MADE A TERRIBLE MISTAKE. Must vacate.

Noon sunlight spirals dimly into the chopsuey joint. Muted music spirals Hindustan. He eats fooyong, she eats chowmein. They dance with their mouths full, slim blue jumper squeezed to black slick suit, peroxide curls against black slick hair.

Down Fourteenth Street, Glory Glory comes the Army, striding lasses, Glory Glory four abreast, the rotund shining, navy blue, Salvation Army band ${ }^{169}$.

Esse não é o trecho em que a colagem de versos musicais mais se destaca, mas vale a pena comentá-lo pois trata-se de um exemplo condensado de montagem. Aqui temos o narrador onisciente que apresenta cenas ("noon on union square"), placas ("selling out"), vozes esparsas recolhidas ao acaso ("Miss maam at the back of the store”) em um local específico da ilha. A região da Union Square, que após o fím da Guerra Civil tinha sido o grande centro da indústria teatral de Nova York, havia se tornado, na virada do século, uma região de teatro de vaudeville e dance halls. Um pouco acima da Union Square, formava-se o Ladie's Mile - principal centro comercial da cidade -, o que fazia com que a circulação de transeuntes e consumidores fosse constante na região ${ }^{170}$. Assim, vemos a ação de um vendedor de loja, os engraxates trabalhando, um estabelecimento comercial fechando (talvez uma consequência da recessão de 1913-1914), um casal dançando em um estabelecimento duvidoso e a marcha do Exército da Salvação. Esse último aparece entoando uma canção cujo refrão diz "Glory! Glory!".

A concatenação de imagens tão díspares cria uma espécie de confronto entre elas que sobrepõe ao texto enunciado uma série de conteúdos não explícitos. Uma das oposições mais agudas talvez seja a que se forma entre o fragmento do comércio fechando, a frase "we made a terrible mistake” e o canto exaltado (“Glória! Glória!”)

\footnotetext{
169 "Meio-dia na Union Square. Liquidação. Passa-se o ponto. NÓS COMETEMOS UM ERRO TERRÍVEL. Ajoelhados no asfalto empoeirado meninos engraxam derbys sapatos marrons sapatos de botões oxfords. $O$ sol brilha como um dente de leão sobre o dedão de cada sapato recém-engraxado. Por aqui, amigo, senhor senhorita senhora nos fundos da loja nossa nova linha de tweed refinado maior qualidade menor preço... Cavalheiros, senhoritas, damas, com descontos... NÓS COMETEMOS UM ERRO TERRÍVEL. Passa-se o ponto./O sol do meio-dia adentra vagamente em espiral um restaurante barato de chop suey. A música abafada espirala Hindustão. Ele come foo young ela come chow mein. Eles dançam com a boca cheia, vestido azul justo apertado contra um terno preto engomado, cachos oxigenados contra um cabelo preto engomado./Descendo a Rua Catorze Glória, Glória vem o Exército, a passos largos, Glória, Glória, quatro lado a lado, a rotunda brilhando, azulmarinho, banda do Exército da Salvação." [Tradução nossa.] DOS PASSOS, John. Manhattan Transfer, cit., p. 122.

${ }^{170}$ BURROWS, Edwin G.; WALLACE, Mike. Gotham, cit., p. 1.132-1.154.
} 
do Exército da Salvação. A justaposição não planifica os elementos, mas potencializa as tensões: o louvor de glória parece tornar ainda mais sombrio o fechamento do estabelecimento comercial ("must vacate") e a misteriosa frase "we have made a terrible mistake". Um segundo conteúdo é acrescentado pela marcha desse corpo quase militar de protestantes, prenunciando a eclosão da guerra que aparecerá dois capítulos adiante e que situará cronologicamente os acontecimentos de toda a segunda parte do romance.

Há ainda uma terceira camada de significação que se revela a partir da menção ao Exército da Salvação e desdobramentos da trama de Joe Harland nos capítulos seguintes. Sabemos que há uma longa história de confrontos entre o Exército da Salvação e o sindicato dos Trabalhadores Industriais do Mundo (I.W.W.). O Exército da Salvação, criado na década de 1880 e emigrado para os Estados Unidos, tinha por praxe realizar marchas públicas nas ruas, durante as quais cantava-se hinos com a presença de uma banda. Antagonista político dos I.W.W., uma das táticas do Exército da Salvação para atrapalhar as atividades do sindicato era enviar uma de suas bandas aos pronunciamentos ou aos estabelecimentos alternativos criados pelos I.W.W. ${ }^{171}$. É nessa época em que os I.W.W., apropriando-se das táticas usadas contra eles, também dão início a uma grande produção de músicas para combater o Exército da Salvação (e outras instituições cristãs).

Esses detalhes, aparentemente sem importância, na verdade nos interessam porque, logo após a aparição do Exército da Salvação marchando pela praça Union Square, temos o episódio de Joe Harland, que foi um importante corretor da bolsa de valores e, miserável, há anos mendigava pelas ruas de Manhattan, alternando períodos de desemprego a breves trabalhos informais. No capítulo seguinte, Joe Harland, agora empregado como vigia no canteiro de obras de um futuro arranha-céu, é abordado por Joe O’Keefe, um grevista sindicalizado. O diálogo entre os dois explicita os impasses entre a luta dos trabalhadores e a precarização das condições de emprego. O capítulo seguinte, por sua vez, em que Joe O’Keefe se encontra com o político corrupto Gus $\mathrm{McNiel}$, sugere as relações entre os sindicatos e a política oficial dos partidos.

Esses três exemplos mostram como a colagem faz aderir à superfície do texto conteúdos diversos que se relacionam de diferentes formas com uma série de

\footnotetext{
${ }^{171}$ Sobre essa disputa, que aparecerá de forma mais clara na trilogia U.S.A., Ver TROMBOLD, John. Popular Songs as Revolutionary Culture in John Dos Passos' U.S.A. and Other Early Works, cit.
} 
elementos da narrativa. Todavia, a importância da colagem de canções não se esgota nas referências históricas que imprime ao texto nem na já citada recuperação do cotidiano a partir da apropriação de um elemento partilhado pelos leitores da época, como uma canção popular. $\mathrm{Na}$ verdade, uma das funções talvez mais instigantes exercidas pela canção é a de comentário.

Retornemos, então, à primeira citação desse subcapítulo, em que vemos Ellen, sob chuva torrencial, em direção à sua lua de mel. Entremeados ao discurso que expressa, por um lado, o desejo de felicidade de Ellen ("I'll be feeling gay") e, por outro, a sua insatisfação (“I've got to be feeling gay”), os versos da canção popular de ninar $^{172}$ afirmam que a chuva que acompanha o primeiro dia de casamento de Ellen não cessará - e a imagem da água e da chuva de fato acompanhará toda a história de Ellen até o fim de sua trajetória, encerrada, como era de se esperar, em um afogamento simbólico, conforme veremos mais adiante.

Formalmente, uma das características desse expediente da colagem de músicas é a maneira como um mesmo material colado (esses ready-mades retirados do cotidiano) aparece em diferentes formulações e reformulações, com efeitos distintos para a obra. Assim, pergunta-se: de que modo isso se realiza na obra e quais os efeitos decorrentes dessas constantes reformulações?

12) A fair young man who had followed her in was reeling intricately round the table singing:

O we went to the animals' fair

And the birds and the beasts were there

And the big baboon

By the light of the moon

Was combing his auburn hair ${ }^{173}$.

Esse breve trecho foi retirado da cena de um banquete grotesco em que o francês Marco trabalha como garçom no segundo capítulo da primeira parte, e os versos destacados pertencem a uma canção popular infantil cujo registro data de 1880 . Trata-se, como no caso da manchete de jornal, de uma inserção com motivação explícita, pois é cantada por alguém [“a fair Young man (...) was (...) singing”], e não integrada: além da disposição gráfica, a heterogeneidade sintática remete imediatamente a um dado apropriado do espaço exterior ao mundo ficcional. Por um

\footnotetext{
172 WAGNER, Linda. Dos Passos. Artists as American. Austin: University of Texas Press, 1979, p. 54.

173 "Um homem jovem que a tinha seguido estava dançando de forma complexa em torno da mesa cantando: Ah nós fomos à feira de animais/E os pássaros e as feras estavam lá/E o grande babuíno/Sob a luz da lua/Penteava seu pelo castanho." [Tradução nossa.] DOS PASSOS, John. Manhattan Transfer, cit., p. 29.
} 
lado, a canção funciona, ficcionalmente, como um dado convencional de composição: uma personagem chegou em cena cantando uma música. Por outro, ela aproximava o leitor à narrativa por ser um dado que ele reconhece em seu próprio mundo; afinal, essa era uma canção muito popular na virada do século. Por fim, a canção produz o efeito de comentário, como se todo o banquete não passasse de uma grotesca orgia de animais - uma cena cujas singularidades ainda serão discutidas adiante.

A cena do banquete é a primeira vez em que esses versos aparecem no romance: por meio de uma colagem de motivação explícita. Essa cena não é, entretanto, a sua única inserção na obra. O seu verso principal ("Went to the animals' Fair") torna-se título do quinto capítulo da segunda parte do romance, em que algumas das personagens mais reincidentes surgem no mesmo local. Aqui, o verso ainda faz um comentário sobre o capítulo todo (“Animals' Fair"), mas dessa vez ele aparece dissimulado e poderia não ser reconhecido pelo leitor como uma citação da música que apareceu oito capítulos antes.

\subsection{Vidro e aço: reiterações e reaproveitamentos das colagens na estrutura narrativa}

Há mais dois exemplos que podemos citar em que esse mecanismo de reaproveitamento de citações é empregado de forma ainda mais radical. O primeiro caso ocorre no sétimo capítulo da segunda parte do romance, Rollercoaster. Nesse capítulo, em que acompanhamos os últimos momentos de Stan antes do incêndio, são autonomizados e rearranjados diversos segmentos que compõem os parágrafos iniciais de Metropolis (segundo capítulo) e Dollars (terceiro capítulo). Ainda em Rollercoaster, esses trechos ficcionais são retirados de seu contexto original e colados de forma a se integrarem ao delírio de $\operatorname{Stan}^{174}$. Na verdade, todos os títulos da segunda parte do romance são citações, seja de músicas que já apareceram ("Longlegged Jack of the Isthmus", "Went to the Animals' Fair", "One More River to Jordan"), seja como menção a algo que foi dito por Ellen ou sobre Ellen: "Great Lady on a White Horse" é como Ellen irá se referir à propaganda de "Danderine Lady" no próprio capítulo; "Nine Days' Wonder" é como o Sr. Goldweiser irá se referir a Ellen; "Fire Engine" faz alusão tanto ao elemento do fogo, reincidente no romance, quanto aos

\footnotetext{
${ }^{174}$ MOREL, Jean-Pierre. Montage et collage et discours romanesque dans les années vingt et trente, cit., p. 41.
} 
sentimentos de Ellen ${ }^{175}$; "Rollercoaster" sugere uma relação com um momento em que o narrador pontua a tristeza de Ellen, dizendo que "She had started to drop with a lurching drop like a rollercoaster's into shuddering pits of misery".

O segundo exemplo desses rearranjos e aproveitamentos na narrativa diz respeito não a colagens de ready-mades, mas à epígrafe do segundo capítulo do romance. Conversando com o seu amigo George Baldwin, o arquiteto idealista Phil Sandbourne reproduz, rearranjando, trechos da epígrafe do segundo capítulo, Metropolis:

13) He's got an idea the skyscraper of the future'll be built of steel and glass. We've been experimenting with vitrous tile recently... cristamighty some of his plans would knock yer eye out... He's got a great sayin about some Roman emperor who found Rome of brick and left it of marble. Well he says he's found New York of brick and that he's goin to leave it of steel... steel an glass ${ }^{176}$.

Embora esse não seja um caso de montagem, e sim de uma cena composta por um diálogo entre duas personagens, o episódio explicita as diferentes repetições e variações de que o romance faz uso. Os mesmos termos que apareceram na abertura do segundo capítulo ("they were built of brick", "Athens was golden marble", "Rome was held up on broad arches of rubble", "Steel, glass, tile, concrete will be the materials of the skyscrapers") surgem aqui ligeiramente alterados e reordenados. A conversa de Phil alude à abertura do capítulo e, consequentemente, a essa corrente de otimismo que parece vigorar nos episódios associados que já discutimos. Os trechos repetidos por Phil Sandbourne são muito singulares e chamam a atenção do leitor para o seu reaproveitamento. Reorganizados, eles criam uma "rede de associações"177 que não pode ser inferida pelo desenvolvimento da trama, mas que ressignifica as partes e sobrepõe os conteúdos, reforçando o carácter montado do texto.

\footnotetext{
${ }^{175}$ Logo antes do capítulo "Fire Engine", há uma cena em que Ellen sente-se assediada pelos homens à sua volta. Sentindo-se fria e distante, como um "farol", algo dispara dentro dela como "a fire engine". DOS PASSOS, John. Manhattan Transfer, cit., p. 154).

176 "Ele tem uma ideia, o arranha-céu do futuro vai ser de aço e vidro. A gente fez testes com azulejo vítreo recentemente... nossenhora tem uns planos deles que iam te deixar de boca aberta... Ele tem um ditado bom sobre um imperador romano que encontrou Roma de tijolo e a deixou em mármore. Bom, ele diz que encontrou Nova York feita em tijolo e vai deixa-la de aço.... aço e vidro." [Tradução nossa.] DOS PASSOS, John. Manhattan Transfer, cit., p. 63.

${ }^{177}$ MOREL, Jean-Pierre. Montage et collage et discours romanesque dans les années vingt et trente, cit., p. 66.
} 
Assim como ocorreu na consolidação da região de Nova York pela reunião da ilha de Manhattan, Staten Island, Bronx Brooklyn e Queens (os dois últimos de Long Island), os fragmentos que constituem o romance mantêm a sua autonomia uns em relação aos outros, mas há algo novo que une essas "ilhas" e que estabelece um princípio de unidade. O princípio estilístico do romance, a montagem, reforça, por um lado, a experiência de dispersão e, por outro, exige do leitor uma construção de "pontes" capazes de determinar as relações entre as partes. A montagem, como vimos, opera essa dupla função nos diversos níveis do texto. Desde a composição de "múltiplos níveis de enfoque"178 (a miríade de histórias que ou bem se relacionam, ou bem se mantêm isoladas), passando pela concatenação de diferentes estilos e pela inserção de materiais de origem heterogênea, até a narrativa ficcional por meio da colagem.

Um dos aspectos que a montagem consolida, portanto, é a representação de uma experiência urbana ambígua ("It was marvelous, it was hideous. It had to be described"), que resiste à tentativa de síntese, expõe a sua incompletude e afeta tanto as relações que se estabelecem entre as partes autônomas (os fragmentos apresentam pouca ou nenhuma relação entre si) quanto a constituição individual de cada episódio (o encadeamento dos fragmentos que compõem uma mesma trajetória ou a constituição interna de um único fragmento). A forma do romance, como já vimos, não havia sido planejada de antemão, mas foi desenvolvida no trabalho com a matéria $^{179}$. O resultado é uma experiência de representação do espaço e do tempo que colocava em questão as técnicas da linearidade e causalidade narrativas. Para Dos Passos, o tempo da metrópole era simultâneo.

Sem dúvida, uma das características mais marcantes do romance, a simultaneidade, não resume os desdobramentos dessa forma experimental que é a expressão narrativa de uma experiência subjetiva de espaço - uma experiência que, aliás, já vinha sendo tematizada por outros autores da literatura dos Estados Unidos, mas que, com Manhattan Transfer, atinge outro nível de expressão formal e reflexão. Uma das obras que abordou esse tema é o romance de William Dean Howells, $A$ hazard of new fortunes: publicado em 1890, é produto de uma época em que Nova York se consolidou como o centro não apenas comercial mas também cultural dos Estados Unidos, superando Boston - capital da tradição intelectual do país até a

\footnotetext{
${ }^{178}$ CANDIDO, Antonio. Digressão sentimental sobre Oswald de Andrade, cit., p. 55.

${ }^{179}$ PIZER, Donald (Org.). John Dos Passos: the major nonfictional prose, cit., p. 272.
} 
metade do século XX. Com os nomes mais importantes dos círculos intelectuais comandando as editoras e revistas, Boston detinha um controle forte sobre o que era publicado e discutido, perdendo essa influência somente quando as forças econômicas que cresciam em Nova York captaram também o mercado cultural. Não por acaso, duas das personagens mais importantes do romance de Howells são justamente os Marches, um casal que se muda de Boston para Nova York com a intenção de fundar uma revista literária - o percurso da intriga, portanto, remetia aos processos da época, quando intelectuais e até revistas abandonaram Boston para se instalar em Nova York. Mesmo vindos de uma cidade como Boston, as particularidades do novo ambiente não deixam de chamar a atenção do casal:

This immunity from acquaintance, this touch-and go quality in their New York sojourn, this almost loss of individuality at times, after the intense identification of their Boston life, was a relief, though Mrs. March had her misgivings, and questioned whether it were not perhaps too relaxing to the moral fibre. March refused to explore his conscience; he allowed that it might be so; but he said he liked now and then to feel his personality in that state of solution ${ }^{180}$.

No romance de Howells, o grande nome do realismo nos Estados Unidos, a intensificação do contato com estranhos e a consequente escassez de relações pessoais revela-se uma das características mais preponderantes da metrópole, e um fator de risco para a integridade do caráter, para a formação da "fibra moral" do indivíduo. Sem prejuízo da força desse grande romance, a abordagem temática do assunto é ainda delineada por uma prosa nada experimental. Temos um narrador em terceira pessoa, extradiegético e onisciente intruso - nada de inesperado no universo realista de Howells, preocupado em explorar a singularidade desse ambiente que congregava pessoas tão diferentes entre si: um aristocrata sulista, membros da classe média esclarecida, novos ricos e artistas empobrecidos, forçando-os a uma convivência intensa.

Quando comentou, alguns anos mais tarde, sobre a gênese de Manhattan Transfer, Dos Passos observou como a tentativa de expressar a singularidade da vivência nesse espaço que era "o mundo que [ele] conhecia"181 orientou a construção do romance. Especificamente, há duas noções, mais ou menos abstratas, que podemos encontrar repetidas vezes nas observações que o autor proferiu sobre o romance. A

\footnotetext{
${ }^{180}$ HOWELLS, William Dean. A hazard of new fortunes. New York: The New American Library, 1965. p. 257.

${ }^{181}$ DOS PASSOS, John. Contemporary Chronicles (1961), cit., p. 239. "I was trying to get a great many things in to give a Picture of the city of New York because I had spent quite a while there. I was trying also to get a certain feeling in." DOS PASSOS, John. An interview with John Dos Passos (1968), cit., p. 247.
} 
primeira é a noção de simultaneidade, algo que, para Dos Passos, marcou também uma série de movimentos artísticos das primeiras décadas do século XX. No romance, a expressão dessa percepção, que é sobretudo temporal, ocorre por meio da montagem. Como vimos, a justaposição brusca dos elementos heterogêneos e a problematização da relação temporal e causal entre as partes instaura um funcionamento específico, que será discutido com maior atenção mais adiante. A segunda noção que reaparece de forma recorrente quando Dos Passos falava sobre Manhattan Transfer é algo que podemos designar como a insuficiência do herói: a tentativa de organizar esse universo metropolitano em torno da trajetória individual de uma personagem principal poderia restringir e, no limite, podemos supor, falsificaria a matéria histórica sobre a qual se debruçava a sua obra.

A partir dessa segunda noção, a primeira questão a ser colocada por uma pesquisa que se debruce sobre Manhattan Transfer é como abordar essa obra, já que um dos pressupostos convencionais do próprio gênero é o de que a narrativa se desenvolve em torno de uma ou algumas trajetórias individuais bem delimitadas. Ou seja, tradicionalmente, ele se estruturaria com base em um acúmulo de experiências cujos desdobramentos têm consequências para o percurso de uma ou mais personagens. Em oposição a isso, o título do livro já é um bom indício do que o autor pretendia fazer com seu romance: Manhattan Transfer era uma estação em Nova Jersey construída em 1910. Era ali que os passageiros que vinham de outras localidades no continente em locomotivas a vapor podiam fazer a baldeação para uma locomotiva elétrica que os levava até a Penn Station, em Manhattan, por túneis subterrâneos que atravessavam o rio Hudson. Dos Passos escolhe como título de seu romance - ou "sátira social", como ele gostava de dizer -, portanto, uma estação recente, que representava um avanço tecnológico e transformava as possibilidades de acesso à ilha de Manhattan. O título faz referência, então, à metrópole, mas também àquilo que se encontra fora dela, mas permanece latente, em tensão pela força centrífuga da cidade. Esses são, portanto, os aspectos relacionados ao que chamamos de insuficiência do herói.

Já vimos como o princípio estilístico do romance, na justaposição de fragmentos ficcionais e não ficcionais, afeta o encadeamento das ações e a ordenação das tramas. Em última instância, como ainda será discutido, essa organização do ritmo do encadeamento narrativo tem um impacto profundo na noção de causalidade e de temporalidade. Sendo um princípio que rege todo o romance, possui também um 
efeito determinante na estruturação da miríade de vidas de que a narrativa dispõe para superar ou, talvez mais especificamente, problematizar, aquilo que Benjamin, em seu ensaio "Crise do romance. Sobre Alexanderplatz, de Döblin", caracterizou como uma característica decisiva das personagens de romances: "no momento em que o herói consegue ajudar-se, sua existência não pode mais ajudar-nos" ${ }^{\text {182 }}$. Na obra de Dos Passos, as personagens não podem se salvar. Mais do que isso, podemos até questionar se elas são de fato personagens. E, como veremos, a composição das personagens talvez se aproxime daquilo que Gertrude Stein, em seu livro de memórias, destacou como a característica essencial do século XX: "a ideia da produção em série, que uma coisa deveria ser como a outra coisa"183.

${ }^{182}$ BENJAMIN, Walter. Crise do romance. Sobre Alexanderplatz, de Döblin, cit., p. 60.

${ }^{183}$ STEIN, Gertrude apud SEED, David. Cinematic fictions, cit., p. 29. 


\section{SONÂMBULOS: \\ A INSUFIÊNCIA DO HERÓI}

Querer mais da vida

do que o pão com manteiga.. Berlin Alexanderplatz, Alfred Döblin

God! If people were not so damnably adaptable to any form of misery-The fourteenth chronicle, Dos Passos

A transformação dos vínculos sociais e da própria constituição do indivíduo submetidos ao ritmo e à organização da metrópole é tema de uma série de romances estadunidenses da virada do século XX. Sister Carrie, publicado em 1900, por exemplo, é uma obra que se tornou um marco da prosa desse período e para a qual a especificidade do cenário urbano é de primeira ordem. Carrie, uma jovem nascida na pequena Columbia City, muda-se para Chicago durante alguns anos e, depois, sob condições um tanto adversas, instala-se definitivamente em Nova York. O percurso dessa jovem protagonista era exemplar, pois, após o fim da Guerra Civil, uma crise no preço dos produtos agrícolas havia estabelecido um longo período de depressão nas regiões rurais dos Estados Unidos, enquanto as metrópoles prosperavam impulsionadas pelo crescimento industrial que ganhava força no norte do país modelo que passa a ser a referência nacional de modernização ${ }^{184}$. Apesar de representar uma trajetória típica nesse momento histórico (a migração de trabalhadores de áreas rurais para metrópoles industriais), Carrie é uma personagem feminina singular na literatura dos Estados Unidos, cuja composição chocou não só o editor mas também parte da crítica da época e os leitores ${ }^{185}$ : o seu fascínio pela grande cidade, a fácil adaptação aos padrões de Chicago e Nova York, o deslumbramento franco pelo luxo e o desapego emocional, tudo observado por um narrador nada propenso a tranquilizar o seu público aflito com um discurso moralista capaz de compensar e corrigir os excessos de uma personagem que não pede para ser compreendida ou perdoada. Em uma cidade como Nova York, "nunca se sabe quem mora ao lado" - Hurstwood adverte Carrie e, indiretamente, o leitor que, como esse marido desajustado em meio às novas coordenadas espaciais, procura entender essa

\footnotetext{
${ }^{184}$ SMITH, Christopher (Org.). American realism. San Diego: Greenhaven Press, 2000, p.16.

${ }^{185} \mathrm{O}$ romance de Dreiser foi duramente criticado e muito pouco lido até que se tornou um grande sucesso na Inglaterra e foi, finalmente, reeditado nos Estados Unidos em 1911. BRADBURRY, Malcolm. The modern American novel. New York: Oxford University Press, 1992, p. 28.
} 
"quase perda de individualidade" que impressionou também o casal March citado no fim do capítulo anterior. No caso de $A$ hazard of new fortunes, Boston representaria o polo oposto, reduto da herança intelectual do país, da elite puritana, dos valores sólidos e tradicionais. Todavia, quando Sister Carrie foi publicado, Dreiser escolhe Chicago (já uma cidade industrial "moderna") para representar a grande "rival" de Nova York:

O que quer que um homem como Hurstwood pudesse ser em Chicago, era evidente que ele não seria mais do que uma imperceptível gotícula em um oceano como Nova York. Em Chicago, cuja população ainda variava em torno de 500.000, os milionários não eram numerosos. (...) Em outras palavras, Hurstwood não era nada ${ }^{186}$.

No caso dos dois romances comentados (de Howells e de Dreiser), a paisagem metropolitana é fundamental para o desenvolvimento da trama, e a novidade desse ambiente é acentuada pela comparação, por meio da impressão das personagens, a outra forma de vida urbana, mais controlável e compreensível. Em ambos, contudo, o paralelo não possui um caráter conservador: Nova York não é pior ou mais "degenerada" do que as suas "adversárias", mas possui particularidades que a diferenciam de todas as outras capitais dos Estados Unidos e, certamente, exigem uma adaptação específica por parte de quem lá se aventura. O tema do efeito da urbanização sobre os indivíduos é, como vimos nos trechos transcritos, expressado e analisado por um narrador comentador, capaz de organizar aquilo que, muitas vezes, as personagens nem sequer são capazes de exprimir com clareza ${ }^{187}$.

Assim como o romance de Dreiser principia com essa criatura curiosa a bordo de um trem em direção à Chicago, Manhattan Transfer, publicado vinte e cinco anos depois, abre com uma balsa em movimento a caminho do porto de Nova York e o seu primeiro capítulo é uma sucessão descontínua de histórias de chegadas e adaptações.

\footnotetext{
${ }^{186}$ Tradução nossa do original: "Whatever a man like Hurstwood could be in Chicago, it is very evident that he would be but an inconspicuous drop in an ocean like New York. In Chicago, whose population still ranged about 500,000, millionaires were not numerous. (...) The sea was already full of whales. (...) In other words, Hurstwood was nothing. DREISER, Theodore. Sister Carrie, cit., p. 305.

${ }^{187}$ Do mesmo modo como em Howells é explícita uma posição autoral afeita ao comentário, em Dreiser o narrador, ainda que de forma um pouco mais sutil, não deixa de exibir a precisão de seu espírito crítico em prejuízo de sua personagem: "Caroline, or Sister Carrie, as she had been half affectionately termed by the family, was possessed of a mind rudimentary in its power of observation and analysis. Self-interest with her was high, but not strong. It was, nevertheless, her guiding characteristic. Warm with the fancies of youth, pretty with the insipid prettiness of the formative period, possessed of a figure promising eventual shapeliness and an eye alight with certain native intelligence, she was a fair example of the middle American class - two generations removed from the emigrant. Books were beyond her interest—knowledge a sealed book". DREISER, Theodore. Sister Carrie, cit., p. 2.
} 
Não temos, porém, uma figura central como Carrie nem um narrador empenhado e comentador como aquele construído por Dreiser. Ademais, o tipo de ponderação reflexiva que acabamos de ver acerca da relação entre indivíduo e espaço coletivo da metrópole não comparece no texto de Dos Passos, nem pela voz do narrador, nem na boca das personagens nos diálogos travados. Todavia, o que era conteúdo enunciado pelo narrador de Sister Carrie (a força operada pela metrópole na constituição do indivíduo e as suas relações pessoais) é a tensão latente do romance de Dos Passos tensão esta que se projeta e se revela, de forma mais evidente, nas trajetórias individuais que se organizam, superficialmente, entre histórias de "sucesso" e "fracasso". Como apontou o crítico francês Astre, "todas as personagens de Manhattan Transfer (...) só podem ser definidas em relação ao 'sucesso' ou ao 'fracasso' - no sentido social do termo, e segundo as normas da cidade"188. Essa impressão não é nova e já havia sido sugerida em 1927 por D. H. Lawrence em sua resenha sobre o romance de Dos Passos. Nela, Lawrence aponta como o ritmo do livro, uma desconcertada justaposição entre conquistas e derrotas, gera uma "confusão genuína", uma representação não afetada da vida na metrópole ${ }^{189}$. Essa vida ganha materialidade não só na "captação" dos sons e imagens da cidade, como sugere Lawrence, mas também na própria dinâmica da forma descontínua, que age igualmente sobre as personagens. Vejamos como.

\subsection{Entreatos}

É em um fim de tarde no sul da ilha de Manhattan, em Battery Park, que Ellen formula para o seu pai as suas primeiras noções acerca da posição econômica que eles realmente ocupam e as suas fantasias infantis sobre a condição que ela gostaria de ter.

13) On the big modern liners they do.'

'Daddy why dont we go?'

'Maybe we will some day if I can save up the money.'

'Oh daddy do hurry up an save a lot of money. Alice Vaughan's mother an father go to the White Mountains every summer, but next summer they're going abroad.'

Ed Thatcher looked out across the bay that stretched in blue sparkling reaches into the brown haze towards the Narrows. The statue of Liberty stood up vague as a sleepwalker among the curling smoke of tugboats and the masts

\footnotetext{
${ }^{188}$ E ele continua: "O que implica um mundo onde os valores são rigorosamente invertidos, o verdadeiro sucesso não podia ser, aos olhos de Dos Passos naquela época, senão um insucesso aparente" [tradução nossa]. ASTRE, Georges-Albert. Thèmes et structures dans l'ouvre de John Dos Passos. Paris: Lettres Modernes, 1956, p. 148.

${ }^{189}$ LAWRENCE, D. H. Review (1927), cit., p. 75.
} 
of schooners and the blunt lumbering masses of brickbarges and sandscows. Here and there the glary sun shone out white on a sail or on the superstructure of a steamer. Red ferryboats shuttled back and forth.

'Daddy why arent we rich?'

'There are lots of people poorer than us Ellie... You wouldn't like your daddy any better if he were rich would you?'

'Oh yes I would daddy' ${ }^{190}$.

A cena em si representa uma situação cotidiana: pai e filha observam o rio, os navios e, ao longe, a Estátua da Liberdade. Nesse breve episódio, resumidamente, nada acontece: não há um grande evento nodal que implique uma mudança de rumo na vida de Ed ou de Ellen. Como diz Franco Moretti, trata-se de uma apresentação do “caráter ordinário da vida"191 . "O drama de uma xícara quebrada, a tragédia de uma volta no quarteirão" ${ }^{\text {192 }}$, lamentaria Frank Norris, criticando a carência de imaginação dos escritores realistas de seu tempo.

No romance de Dos Passos, a vida de Ellen - e, como veremos, a da maioria das personagens - parece transcorrer em entreatos. Na passagem destacada em que, no Battery Park, Ellen e seu pai contemplam os barcos, temos um diálogo breve, sem acontecimentos trágicos ou decisivos para o futuro da família. Tematicamente, tratase de um momento de descoberta de diferenças. Nas cenas anteriores, o leitor viu Ellen, impressionada com a peça Peter Pan interpretada pela grande estrela da época, Maud Adams ${ }^{193}$, declarar que queria ser um menino (“Oh mummy I want to be a little boy" ${ }^{\prime 194}$ ). O diálogo à beira do rio com seu pai exprime um período de transição em que Ellen começa a perceber as diferenças sociais que a restringem: em primeiro lugar,

\footnotetext{
190 “'Nos grandes navios eles dançam.' 'Pai, por que a gente não vai?' 'Talvez a gente vá um dia se eu economizar um dinheiro.' 'Ai, pai, então economiza logo um monte de dinheiro. A mãe e o pai da Alice Vaughan vão pras Montanhas Brancas todo verão, mas no próximo verão eles vão pro exterior'. Ed Thatcher olhou pela baía que se estendia numa vastidão azul reluzente atravessando a névoa marrom até o estreito. A estátua da Liberdade estava em pé distraída como um sonâmbulo entre a fumaça ondulada dos rebocadores e dos mastros das escunas e as massas pesadas e secas de barcaças de tijolo e chatas de areia. Por todo lado, o sol ofuscante brilhava branco numa vela ou na estrutura de um navio a vapor. Balsas vermelhas iam e voltavam. 'Pai, por que a gente não é rico?' 'Tem muita gente mais pobre que a gente, Ellie... Você não ia amar mais seu pai se ele fosse rico, né?' 'Ah, eu ia sim, pai."” [Tradução nossa.] DOS PASSOS, John. Manhattan Transfer, cit., p. 52.

${ }^{191}$ MORETTI, Franco. O século sério. In: MORETTI, Franco (Org.). A cultura do romance. São Paulo: Cosac Naify, 2009, p. 827.

192 "The drama of a broken teacup, the tragedy of a walk down the block." NORRIS, Frank. A plea for Romantic Fiction. In: PIZER, Donald (Ed.). Documents of American realism and naturalism. Carbondale; Edwardsville: Southern Illinois University Press, 1998, p. 172.

193 "We're just excited, Susie. We've been to the most wonderful play. You'd loved it, it's so poetic and all that sort of thing. And Maud Adams was fine. Ellie loved every minute of it." DOS PASSOS, John. Manhattan Transfer, cit., p. 20. Sabe-se que a peça foi encenada em 1905 e 1906 na Broadway, em Nova York e tinha Maud Adams como personagem principal.

194 “Mamãe, eu quero ser um menino.” DOS PASSOS, John. Manhattan Transfer, cit., p. 20.
} 
diferenças de gênero ${ }^{195}$; em segundo lugar, econômicas. Portanto, embora a cena não represente um grande desdobramento para a trama, ela é iluminadora, pois reverberará no percurso da futura atriz, cuja vida se organiza de modo a garantir o sucesso de sua carreira (o fator econômico) e é marcada por sua relação conflituosa com mulheres e homens (a determinação de gênero).

Essa cena em Battery Park é o último episódio em que o leitor encontra Ellen ainda criança. O próximo fragmento da personagem já não se estrutura mais em torno do antigo núcleo familiar: agora, na viagem de lua de mel, a cena tem como centro de consciência a personagem de Ellen, uma jovem adulta, e o tema é a sua relação com John Oglethorpe, seu marido.

14) Rain lashed down the glaring boardwalk and crashed in gusts against the window like water thrown out of a bucket. Beyond the rain she could hear the intermittent rumble of the surf along the beach between the illuminated piers. She lay on her back staring at the ceiling. (...) Oh I'm going to be sick. She went into the bathroom and closed the door. When she had vomited she felt better. Then she climbed into bed again careful not to touch John. If she touched him she would die. She lay on her back with her hands tight against her sides and her feet together. The parlorcar rumbled cozily in her head; she fell asleep. ${ }^{196}$

De forma similar ao trecho anterior (e como será recorrente ao longo do romance), trata-se de uma situação que, a rigor, não modifica em nada o desenvolvimento da narrativa. Vemos apenas as consequências de uma ação - o casamento de Ellen -, essa, sim, modificadora, já tomada no passado, mas sobre a qual o leitor nada sabe. Quando Ellen decidiu casar-se e como reagiu a sua família? Não sabemos e, na cena da lua de mel, não há nenhuma grande tragédia, nenhuma decisão definidora de cursos.

Durante toda a primeira parte do romance, a frequência dos fragmentos do pai de Ellen, Ed Thatcher, sugere que ele será uma personagem constante no livro - o que não se concretiza. Logo nas primeiras páginas, nós o vemos entrando na maternidade em que a sua esposa acaba de dar à luz uma menina, Ellen: "When Ed Thatcher

\footnotetext{
195 “'When I grow up will I be able to talk to people on the street like that?' 'No deary you certainly will not.' 'If I'd been a boy could I?' 'I guess you could.'” DOS PASSOS, John. Manhattan Transfer, cit., p. 53.

196 "A chuva caia torrencialmente sobre o calçadão lustroso e batia em rajadas contra a janela como água arremessada de um balde. Para além da chuva ela podia ouvir o ruído intermitente da rebentação ao longo da praia entre os cais iluminados. Ela deitou de costas olhando para o teto [...]. A, eu vou passar mal. Ela foi pro banheiro e fechou a porta. Depois de vomitar, ela se sentiu melhor. Aí ela subiu na cama com cuidado para não tocar no John. Se encostasse nele, ela morreria. Ela deitou de costas com as mãos grudadas no corpo e os pés juntos. O carro-salão ressoava reconfortante em sua cabeça. Ela pegou no sono". [Tradução nossa] DOS PASSOS, John. Manhattan Transfer, cit., p. 52.
} 
climbed the marble steps of the hospital entry he was trembling"197. Nos capítulos seguintes, Ed aparece em cenas familiares - todos momentos curtos, os quais não podem ser classificados como "eventos decisivos", mas que servem para demonstrar a dinâmica da família, os detalhes do cotidiano. No penúltimo capítulo da primeira parte, Ed reaparece no escritório em que trabalha:

15) But Ed, Gibbons and Swandike had started buying already at three cents when the market closed this evening... Klein got wise an'll be right there with bells on first thing in the morning. The market'll go crazy on it...'

'Unless the fellers doin the dirty work change their minds. I know that stuff through and through, Viler... Sounds like a topnotch proposition... But I've examined the books of too many bankrupts.'

Viler got to his feet and threw his cigar into the cuspidor. 'Well do as you like, damn it all... I guess you must like commuting from Hackensack an working twelve hours a day...'

(...) Take a plunge and come up with three hundred and twentyfive thousand, six hundred and sixtysix dollars. Dollars swarming up like steam, twisting scattering against the stars. Millionaire Thatcher leaned out of the window of the bright patchouliscented room to look at the darkjutting city steaming with laughter, voices, tinkling and lights; behind him orchestras played among the azaleas, private wires click click clickclicked dollars from Singapore, Valparaiso, Mukden, Hongkong, Chicago. Susie leaned over him in a dress made of orchids, breathed in his ear.

Ed Thatcher got to his feet with clenched fists sniveling; You poor fool whats the use now she's gone. I'd better go eat or Ellen'll scold me. ${ }^{198}$

A cena, em si, não representa um grande evento na vida de Thatcher: há muitos anos na mesma firma, não deve ser a primeira vez que ele recebe uma oferta desse tipo. O episódio, contudo, serve para reforçar alguns aspectos do caráter da personagem, já indicados em outros fragmentos ao longo no livro, como a tendência a evitar riscos e a longos devaneios. O detalhe que pode passar quase desapercebido é a frase "whats the use now she's gone". Susie, esposa de Ed e mãe de Ellen, morreu - e sobre esse evento, certamente marcante para a personagem, o leitor não tem qualquer

\footnotetext{
197 "Quando Ed Thatcher subiu os degraus de mármore da entrada do hospital ele estava tremendo" [Tradução nossa]. DOS PASSOS, John. Manhattan Transfer, cit., p.5.

198 “"Mas Ed, Gibbons \& Swandike já começaram a comprar a três centavos quando a bolsa fechou no fim da tarde... O Klein foi esperto e vai chegar com tudo cedinho de manhã. O mercado vai surtar com elas ...' 'A não ser que os caras fazendo o trabalho sujo mudem de ideia. Eu já conheço essa história de cor e salteado, Viler... Parece uma ideia excelente... Mas já analisei as contas de muitos falidos.' Viler levantou e atirou o charuto na cuspideira. 'Bom, faça como quiser, dane-se ... Acho que você deve gostar de morar em Hackensack e trabalhar doze horas por dia ...' (...) Se atirar de cabeça e ganhar trezentos e vinte e cinco mil seiscentos e sessenta e seis dólares. Dólares enxameando como vapor, torcendo alastrando-se contra as estrelas. O milionário Thatcher inclinado na janela da sala iluminada e cheirandopatchouli para ver a cidade projetandopreto fumegante com risadas, vozes, tinidos e luzes; atrás dele orquestras tocavam entre azaléas, linhas privadas click click clickclicavam dólares de Singapura, Valparaiso, Mukden, Hongkong, Chicago. A Susie se inclinava sobre ele em um vestido feito de orquídeas, respirava em seu ouvido. Ed Thatcher levantou-se com punhos cerrados resmungando; Seu pobre coitado que que adianta agora que ela se foi. Melhor eu comer, ou a Ellen vai brigar comigo."” [Tradução nossa.] DOS PASSOS, John. Manhattan Transfer, cit., p. 92-93.
} 
pista. É como se certos acontecimentos que pudessem apresentar uma tendência ao drama fossem deixados deliberadamente de lado e apenas aludidos lateralmente. Isso quer dizer que, se há personagens mais constantes e recorrentes, também as suas trajetórias sofrem o processo de fragmentação que estrutura toda a obra, e ao leitor aparecem apenas aqueles cacos de uma vida incompleta.

Disso resulta a impressão de que o leitor é privado dos momentos decisivos que definem os rumos da vida dessas personagens: não sabemos quando a mãe de Ellen morreu, como ela conheceu Jojo (Oglethorpe) e de que forma teve início a sua carreira no teatro. É como se toda nova cena fosse um começo de romance in medias res sem, contudo, a orientação de um narrador indiscreto afeito a revelações e explicações ou mesmo flashbacks informativos ${ }^{199}$.

E é nessa imersão na textura dos movimentos cotidianos que se configura a força da narrativa de Dos Passos. A aversão de Ellen ao contato físico com o seu marido (por quem, apesar disso, ela nutre uma forma sincera de afeto ${ }^{200}$ ) é chocante, mas permanece, por ora, sem explicação. O narrador nada esclarece e descobrimos apenas pela fofoca das atrizes, na segunda parte do romance, que a futura estrela possivelmente se casou por interesse com o ator Jojo. Este, provavelmente homossexual, já fazia parte do meio do teatro e, por isso, teria sido responsável por lançar a carreira dessa jovem aspirante a atriz.

A estrutura fragmentária discutida no capítulo anterior desta tese também afeta, portanto, a constituição interna de cada uma das tramas do romance. Exige-se que o leitor reúna as peças esparsas, pois o princípio da montagem subtrai o narrador comentador para configurar uma voz narrativa relativamente homogênea. A sua posição parece manter-se de forma mais ou menos consistente em um "modo câmera", armando o seu discurso por meio de verbos no passado (predominantemente o simple past), de exposições dramáticas das cenas e descrições "objetivas".

\footnotetext{
${ }^{199}$ Em 1918, Dos Passos continuava escrevendo um romance iniciado em 1917 com um amigo, Seven Times around the Walls of Jericho, que permaneceu inacabado, mas deu origem a One man's initiation - 1917. Lendo para dois amigos (Jack e Van) trechos de seu romance, Dos Passos expressa uma opinião sobre a construção do romance que não deixa de ressoar no que diz respeito à estrutura de Manhattan Transfer: "their sum criticism was (...) that too much was left unsaid, so that the unfortunate reader wallows desperately in a slough of constant misunderstandings. My retort was that happenings meant nothing in themselves, anyway". [Grifo nosso.] DOS PASSOS, John. The fourteenth chronicle, cit. p. 129.

200 "Look here Dick, honestly I'm very fond of Jojo. I owe him a great deal... He's a very fine person in many ways." DOS PASSOS, John. Manhattan Transfer, cit., p. 205.
} 
O termo "objetivo" foi utilizado inúmeras vezes pelo próprio Dos Passos para caracterizar o seu estilo. Por um lado, a expressão indica certa vertente literária à qual o autor pretendia se opor, exemplificada em Ulisses, de James Joyce ${ }^{201}$. Sem prejuízo do fato de o romance irlandês ter sido uma influência muito importante, principalmente no uso de técnicas e experimentação de linguagem, para Dos Passos, ele representaria uma tendência subjetiva da prosa modernista, o exato oposto do que pretendia. Por outro lado, a "objetividade" sugeriria também certa filiação, embora pouco assertiva (Dos Passos sempre achou difícil indicar uma proximidade entre Manhattan Transfer e outras obras), a Flaubert, um autor ao qual se dedicara desde a adolescência $^{202}$. Contudo, o emprego da expressão "objetivo" com o fito de distinguir uma característica particular da narrativa é vago e diz muito pouco dos efeitos específicos que pode sugerir: trata-se da imparcialidade na observação, de uma qualidade desapaixonada de escrita? Dependeria da descrição detalhada do espaço físico, ou ainda de referências a acontecimentos de conhecimento público? Apesar do que afirma o autor, talvez seja mais fácil recorrer a alguns aspectos do próprio texto para tentar identificar as particularidades das técnicas utilizadas, compreender as suas implicações para a fatura do romance e analisar o que pode ser a "objetividade" almejada por Dos Passos.

\subsection{Documentar a cidade}

Quando Joseph Warren Beach escreveu American fiction, 1920-1940, o seu objetivo era organizar um panorama dos escritores contemporâneos mais importantes de seu país e verificar se havia, entre eles, alguns eixos em comum, apesar das francas diferenças. Dos muitos traços que marcavam a obra desses escritores, Beach destaca um tipo específico de constituição da voz narrativa, característica desses "realistas" estadunidenses que ele havia selecionado e que seguiam, por sua vez, uma tendência da narrativa ocidental configurada após meados do século XVIII, na qual o narrador

\footnotetext{
201 "Ulysses got linked in my mind with Sterne's Tristam Shandy. They are both subjective novels. My interests were the opposite: I wanted to write objectively." DOS PASSOS, John. Contemporary Chronicles (1961), cit., p. 239.

202 "Flaubert is, anyway, one of my Olympian gods, even the Cloud-Compeller himself." DOS PASSOS, John. The fourteenth chronicle, cit., p. 120.
} 
aparece "avesso a debater com o leitor, a se expor" ${ }^{203}$. No caso desses escritores estadunidenses, fazer com que o autor permanecesse "fora da narrativa" seria, segundo Beach, uma reação "contra o didatismo, o paternalismo do escritor vitoriano" 204

Dentre esses narradores "antivitorianos", Beach inclui aquele criado pela obra de Dos Passos, uma das mais importantes da época, segundo o crítico. A descrição de Beach sobre esse tipo de narrativa (a "saída do autor") é ainda imprecisa e implica, na verdade, uma simplificação ${ }^{205}$, mas as suas formulações tiveram reverberação em outras teorias bastante difundidas, como a de Wayne Booth. ${ }^{206}$ A partir das definições que Booth estabelece em The rethoric of fiction, em Manhattan Transfer teríamos um narrador impessoal que objetiva mostrar os eventos no curso de sua ação, em vez de recorrer ao uso de um sumário narrativo, relatando, por exemplo, que a tal hora da manhã, a balsa que atracou em Manhattan trouxe consigo um jovem pobre de uma área rural, assombrado por um passado obscuro e movido pelo sonho de tentar a sorte na cidade grande. Ao contrário, não sabemos de onde parte a balsa que Bud toma e é apenas por meio da fala da própria personagem que o leitor descobre o destino daquela embarcação, Manhattan. Até aqui, nada muito distante da caracterização feita por Beach. Entretanto, na teoria de Booth ganha relevância a distinção, já conhecida nos estudos literários e mencionada pelo próprio Beach, entre mostrar e contar ${ }^{207}$. A impessoalidade do narrador de Manhattan Transfer, a sua tendência a mostrar como uma câmera, dependeria de uma composição textual que procura eliminar os traços autorais: o narrador de Manhattan Transfer não emite comentários explícitos que denotem um julgamento evidentemente pessoal, embora as divisas entre mostrar e

\footnotetext{
${ }^{203}$ Tradução nossa do original: "Disinclined to discuss things with the reader, to come into the open". BEACH, Joseph Warren. American fiction 1920-1940. New York: The Macmillam Company, 1942, p. 16.

${ }^{204}$ BEACH, Joseph Warren. American fiction 1920-1940, cit., p. 16: "If the author has nothing to say about the behaviour of his characters, he feels that he may escape the imputation of being a preacher or a sentimentalist. it is considered to be more in conformity with the principle of esthetics that the work of art should be left to speak for itself; more of an artistic achievement if it is so constructed that it does speak for itself with its own eloquence and is not dependent on the comments of the museum guide".

${ }^{205}$ COHN, Dorrit. Narrated Monologue: Definition of a Fictional Style. Comparative Literature, v. 18, n. 2, p. 102, Spring 1966. Disponível em: <http://www.jstor.org/stable/1770156>. Acesso em: 08 ago. 2016.

${ }^{206}$ COHN, Dorrit. Narrated Monologue..., cit., p. 102.

${ }^{207}$ Ao tratar dessa distinção, Booth cita justamente um trecho de Joseph Warren Beach. BOOTH, Wayne. The rethoric of fiction, cit., p. 25.
} 
contar sejam, no limite, arbitrárias, uma vez que, como ressalta Booth, qualquer opção narrativa implica a presença de um autor que seleciona e ordena ${ }^{208}$.

De toda forma, a Booth interessa evidenciar a tentativa de produzir um efeito narrativo: ao evitar produzir inserções que fossem imediatamente associadas a uma tomada de posição particular por parte da voz autoral, o narrador produz a impressão de que os fatos transcorrem sem mediação frente aos olhos do leitor.

Na cena do suicídio de Bud, por exemplo, temos a seguinte descrição:

16) Captain McAvoy of the tugboat Prudence stood in the pilothouse with one hand on the wheel. In the other he held a piece of biscuit he had just dipped into a cup of coffee that stood on the shelf beside the binnacle. He was a wellset man with bushy eyebrows and a bushy black mustache waxed at the tips. He was about to put the piece of coffeesoaked biscuit into his mouth when something black dropped and hit the water with a thudding splash a few yards off the bow ${ }^{209}$.

A cena imediatamente anterior a essa, retratando os últimos momentos da vida de Bud, é profundamente amarga e é justaposta à descrição banal do café com bolachas do capitão. A ironia estabelecida pela contraposição entre o devaneio do faminto Bud, delirando antes de morrer com um pomposo casamento, e o fato de o Capitão estar a caminho do altar é seca, quase cruel. Analisando a montagem das duas cenas, Aline Soler apontou como, ao concatená-las bruscamente, "a mudança de perspectiva sugere uma mudança na condição de existência de Bud: sujeito que se torna objeto, sujeito reificado" $" 210$.

No que diz respeito à voz narrativa, nesse episódio, seria possível argumentar que o narrador se adianta e anuncia, de saída, o nome do capitão do navio. Certamente, isso ocorre também em outros momentos, já que, como foi dito, a construção da voz narrativa não é perfeitamente homogênea. Contudo, é interessante notar como nesse trecho, à exceção do nome do capitão, todos os outros dados podem ser inferidos de uma simples observação da cena: a vestimenta do homem no barco indica a sua

\footnotetext{
${ }^{208} \mathrm{Se}$ aqui estamos falando da voz narrativa do romance, omissa, que recusa comentários e explicações, o princípio estilístico do romance, a montagem, não pode ser resumido a essa dicotomia, pois a montagem é fundamentalmente uma forma de agir sobre a própria narrativa. Os seus desdobramentos e implicações serão discutidos no quinto capítulo.

209 “O Capitão McAvoy do rebocador Prudence estava na casa do leme com uma mão no timão. Na outra ele segurava um pedaço de bolacha que tinha acabado de molhar na xícara de café que estava na prateleira ao lado da bitácula. Era um homem robusto com sobrancelhas volumosas e um bigode volumoso e negro encerado nas pontas. Estava prestes a botar o pedaço de bolacha encharcado na boca quando algo escuro caiu e bateu na água com um baque surdo a poucos metros da proa". [Tradução nossa] DOS PASSOS, John. Manhattan Transfer, cit., p. 105.

${ }^{210}$ SOLER, Aline Shaaban. A metrópole e a prosa cinematográfica no modernismo estadunidense: Uma abordagem de "Manhattan Transfere de John Dos Passos. 2015. 90 f. Dissertação (mestrado em Estudos Literários) - Universidade Estadual Paulista “Júlio de Mesquita Filho", Faculdade de Ciências e Letras, Araraquara, 2015. p.51.
} 
posição de capitão do navio, o seu bigode farto e o seu físico robusto parecem facilmente notáveis a distância. A construção da cena a partir da suposição do olhar de um terceiro gera a sensação de que o evento narrado surge de modo imediato, desenvolvendo-se no presente da leitura ${ }^{211}$.

Para observar como a descrição das personagens é, muitas vezes, motivada a partir daquilo que o olhar pode apreender, talvez uma das cenas mais interessantes esteja logo na abertura do livro, quando Bud pede, pela primeira vez no romance, informações sobre a cidade:

17) 'Say, friend, how fur is it into the city from where this ferry lands?' he asked a young man in a straw hat wearing a blue and white striped necktie who stood beside him.

The young man's glance moved up from Bud's road-swelled shoes to the red wrist that stuck out from the frayed sleeves of his coat, past the skinny turkey's throat and slid up cockily into the intent eyes under the broken-visored cap.

'That depends where you want to get to.'

'How do I get to Broadway?... I want to get to the center of things.'

'Walk east a block and turn down Broadway and you'll find the center of things if you walk far enough ${ }^{212}$.

Nesse trecho, há uma radicalização da postura do narrador comentada anteriormente, pois tanto a descrição do anônimo quanto a de Bud estão condicionadas à materialidade da visão de outra personagem, e não a um eventual olhar do leitor imaginado. A partir da visada lançada pelo interlocutor de Bud, nós, leitores, vemos os seus sapatos rotos, os punhos puídos do casaco, o seu pescoço fino e avermelhado.

Essa inclinação dedicada à apresentação dos eventos tal como se dariam a perceber no mundo factual, como já dissemos, exclui a utilização de sumários narrativos. De fato, não se encontra ao longo do romance trechos em que o narrador interrompe a progressão do enredo para desenvolver uma espécie de analepse ou de segmento digressivo, em que aspectos não contemplados pela intriga são retomados e explicados para oferecer ao leitor um ponto de vista privilegiado em relação a um

\footnotetext{
${ }^{211}$ Outras implicações acerca da cena do suicídio de Bud serão comentadas no próximo capítulo.

212 “'Diz, amigo, quão longe fica a cidade daqui de onde a balsa atraca?' ele perguntou prum jovem em chapéu de palha vestindo uma gravata listrada de azul e branco que estava ao seu lado. O olhar do jovem subiu desde os sapatos gastos de estrada (roadswelled) até os pulsos vermelhos que despontavam dos punhos rotos do seu casaco, passando pela garganta fina de peru e deslizou arrogantemente para os olhos atentos sob a boina de aba quebrada. 'Depende de onde você quer ir.' 'Como eu chego na Broadway?... Eu quero chegar no centro de tudo.' 'Ande um quarteirão pro leste e desça a Broadway e você vai chegar no centro de tudo se andar bastante." [Tradução nossa.] DOS PASSOS, John. Manhattan Transfer, cit., p. 3.
} 
simples observador. Em vez de situar-se no alto de um arranha-céu, a partir de onde compreende-se a totalidade, a perspectiva move-se no chão da cidade ${ }^{213}$.

Do período que Jimmy e Ellen passaram na França durante a guerra, por exemplo, o leitor descobre apenas fragmentos enunciados pelas próprias personagens. No caso de Jimmy, desse período sangrento na Europa resta uma lembrança idílica que mais parece obra da imaginação romanceada de um escritor. Não temos informação, como leitores, nem da forma como se desenvolveu o relacionamento amoroso entre duas das personagens mais recorrentes do livro, nem do evento internacional mais significativo da época, a Primeira Guerra Mundial. O narrador se abstém de qualquer observação sobre esses anos e sobre os eventos que se desenrolam fora dos limites geográficos da metrópole. A narrativa parece sempre presa ao momento presente e ao espaço da cidade, que não se reconcilia com os demais.

Além das lacunas nas histórias, há certos momentos em que a retração do narrador cria empecilhos narrativos. Um exemplo interessante é a cena em que Congo e Emile tomam café da manhã com Marco em um trailer-lanchonete:

18) They ordered coffee and doughnuts in a lunchwagon on a vacant lot.

'Eh bien you like it this sacred pig of a country?' asked Marco.

'Why not! I like it anywhere. It's all the same, in France you are paid badly and live well; here you are paid well and live badly.'

'Questo paese e completamente soto sopra.'

'I think I'll go to sea again...'

'Say why de hell doan yous guys loin English?' said the man with a cauliflower face who slapped the three mugs of coffee down on the counter.

'If we talk Engleesh,' snapped Marco 'maybe you no lika what we say. ${ }^{, 214}$

Aqui temos uma imprecisão da qual um narrador comentador facilmente daria conta, mas cujo resultado na narrativa de Dos Passos fica obscuro. O diálogo entre as três personagens é em inglês, mas transcorre permeado por algumas expressões em outro idioma além de contar, inclusive, com uma frase inteira em italiano. Contudo, uma única frase dita em outra língua não justificaria a provocação do garçom ("E por que diabos vocês não aprendem inglês?") nem a réplica de Marco, "Se a gente falar

\footnotetext{
${ }^{213}$ Ver GELFANT, Blanche. The American city novel. Norman: The University of Oklahoma Press, 1954.

214 “'Eles pediram um café e donuts em um trailer de comida num terreno baldio. 'Eh bien você gosta dessa droga de país?' perguntou Marco. 'Por que não? Gosto de todo lugar. É tudo igual, na França você ganha mal e vive bem; aqui você ganha bem e vive mal.' 'Esse país tá de ponta cabeça.' 'Acho que vou pro mar de novo...' 'E por que diabos vocês não aprendem inglês?' perguntou o homem com rosto de couve-flor que passou as três canecas de café no balcão. 'Se a gente falar inglês', disse Marco, 'talvez você não fosse gostar do que dizemos." [Tradução nossa.] DOS PASSOS, John. Manhattan Transfer, cit., p. 31 .
} 
inglês, (...) talvez você não fosse gostar do que dizemos”. Se fossem apenas algumas palavras ditas em língua estrangeira, não faria sentido que Marco afirmasse que ele não compreende aquilo que está sendo debatido. Portanto, podemos supor algumas explicações: ou o sotaque dos três é muito forte, o que atrapalharia a compreensão do garçom, ou eles estão usando mais palavras e expressões do que vemos no romance. Não é nada que comprometa a cena, mas evidencia certos dilemas impostos pela escolha do modo narrativo.

Dos Passos era um grande admirador de Vanity fair, publicado em folhetim entre 1846 e 1847, romance que o acompanhou durante muitos anos. O narrador vitoriano de Thackeray cumpre com rigor o seu papel e não deixa que sombras se espalhem sobre os acontecimentos nem que restem lacunas e dúvidas:

\begin{abstract}
O romancista, que tudo sabe, sabe também isso. (...)
O romancista, já foi dito, tudo sabe, e como estou em uma situação que me permite dizer ao público como Crawley e sua esposa viviam sem qualquer renda, permita que eu suplique aos jornais, que possuem o hábito de extrair partes das várias obras periódicas hoje publicadas, que não copiem os seguintes cálculo e narrativa exatos $(\ldots)^{215}$
\end{abstract}

As nuances de sentimento das personagens mais dissimuladas, as pequenas artimanhas - nada passa desapercebido pelo narrador, que transmite as informações de forma diligente. Cumpre notar também que, tanto desse mundo de pequenas artimanhas quanto do leitor, o narrador de Thackeray está afastado pela ironia - assim como é o espírito sagaz e irônico de Becky Sharp que a situa acima das outras personagens. Estivesse esse narrador vitoriano encarregado de apresentar a conversa dos três imigrantes em um terreno baldio de Manhattan, ele poderia explicar em pormenores o incômodo do garçom ou ainda parafrasear a conversa dos três, explicando o teor da conversa que se daria em idioma estrangeiro. Se Manhattan Transfer compartilha, em algumas cenas, o tom satírico de Vanity fair, seu narrador é avesso tanto aos comentários quanto à ironia em relação ao leitor característica desse romance que Dos Passos tanto admirava. Embora a posição dominante (mas não unívoca) do narrador seja de reserva, mantendo a distância narrativa, que pode ser ora

\footnotetext{
${ }^{215}$ Tradução nossa do original: "The novelist, who knows everything, knows also this. (...) The novelist, it has been said, knows everything, and as I am in a situation to be able to tell the public how Crawley and his wife lived without any income, may I entreat the public newspapers which are in the habit of extracting portion of the various periodical Works now published not to reprint the following exact narrative and calculation (...)". THACKERAY, William M. Vanity fair. Ware, Hertfordshire: Wordsworth Classics, 2001. p. 307, 341.
} 
maior, ora menor, o diálogo, a representação de pensamentos por meio do modo dramático (quase como se assistíssemos a monólogos) e o discurso indireto livre (bastante raro no romance) são três instrumentos mobilizados para permitir ao leitor conhecer, por exemplo, alguns elementos da biografia das personagens.

É curioso que um dos recursos mais aproveitados em romances modernistas, o discurso indireto livre, praticamente não tenha espaço em Manhattan Transfer.

19) Ed Thatcher felt very lonely, full of prickly restlessness. If Susie were only here he'd tell her about the big money he was going to make and how he'd deposit ten dollars a week in the savings bank just for little Ellen; that would make five hundred and twenty dollars a year... Why in ten years without the interest that' $d$ come to more than five thousand dollars. I must compute the compound interest on five hundred and twenty dollars at four per cent. He walked excitedly $^{216}$.

Nesse trecho do segundo capítulo, há uma alternância entre uma exposição dramática dos pensamentos da personagem e de uma construção clássica do discurso indireto livre. Embora aqui os dois procedimentos apareçam muito próximos um do outro, há uma tendência clara da obra de priorizar o modo dramático. Essa inclinação da narrativa pode ser explicada por certa ambiguidade produzida pela estrutura do discurso indireto livre. Consequência da construção ambivalente das frases, a ambiguidade faz com que os enunciados permanecem em uma zona obscura entre a voz do narrador e a da personagem. A primeira voz explicita-se no tempo verbal e no pronome em terceira pessoa ("he'd tell her"). A segunda, no emprego dos advérbios (here), na expressividade francamente subjetiva ("Why in ten years...") e no vocabulário. Dorrit Cohn argumenta que o discurso indireto livre permite a eliminação da distância entre a "quase objetividade" do narrador e as "idiossincrasias" da personagem ${ }^{217}$, produzindo um discurso que é difícil de ser situado. O resultado é uma "perspectiva impossível", que possui diferentes qualidades temporais. Ao estabelecer essa zona de interseção, a técnica do discurso indireto livre tenderia, ainda segundo Cohn, "a comprometer o narrador a atitudes de simpatia ou ironia" 218 , o que representa um espírito contrário à tendência geral da narrativa.

\footnotetext{
216 "Ed Thatcher se sentiu muito sozinho, cheio de uma agitação irritadiça. Se a Susie estivesse aqui, ele iria contar sobre o tanto de dinheiro que ele ia fazer e como ele ia depositar dez dólares por semana numa poupança só pra pequena Ellen; isso ia dar quinhentos e vinte dólares por ano... Então em dez anos sem os juros isso ia dar mais de cinco mil dólares. Eu preciso computar o total de juros sobre quinhentos e vinte dólares a quatro por cento. Ele andava agitado." [Tradução nossa.] DOS PASSOS, John. Manhattan Transfer, cit., p. 11.

${ }^{217}$ COHN, Dorrit. Narrated Monologue..., cit., p. 105.

${ }^{218}$ COHN, Dorrit. Narrated Monologue..., cit., p. 504.
} 
Parece-nos que é justamente essa indeterminação que o romance procurar evitar. Em uma obra na qual o narrador procura "desaparecer completamente por trás da ação que narra"219, a exposição dos pensamentos das personagens de forma dramática cria um efeito de transparência em relação à sua interioridade. Assim como o recuo do narrador, que procura representar os fatos e acontecimentos sem qualquer comentário, como se transcorressem frente ao leitor, ao evitar o discurso indireto livre, a narrativa oferece o efeito de um acesso imediato à personagem: o narrador tenta desnudar coisas e pessoas com o mesmo grau de abstenção ${ }^{220}$. O que se parece querer evitar em Dos Passos é a explicitação de uma ordenação indireta dos pensamentos, operada pelo narrador - pensamentos que não necessariamente foram ordenados pelo sujeito.

No mesmo ano em que Dos Passos publicou Manhattan Transfer, também veio a público o romance Mrs. Dalloway, de Virginia Woolf. Nele, as técnicas do discurso indireto livre e de monólogo interior se mesclam de forma bastante irregular, em um processo de complementaridade. Contudo, a lógica do romance de V. Woolf não impede que o narrador assuma uma posição mais participativa, alterando a perspectiva e abrindo o ângulo de visão do leitor. No início do romance, por exemplo, quando Clarissa está na florista e um ruído forte na rua a assusta, o narrador corta por um breve momento o curso dos pensamentos da personagem principal. Ele não oferece detalhes que fujam àquilo que Clarissa já sabe, mas distancia o foco da personagem e abre um campo de visão um pouco mais panorâmico:

The violent explosion which made Mrs Dalloway jump and Miss Pym go to the window and apologize came from a motor car which had drawn to the side of the pavement precisely opposite Mulberry's shop window ${ }^{221}$.

Esse tipo de "intromissão" é evitada a todo custo em Dos Passos. Se o narrador de Woolf pode advertir o leitor de que a personagem que aparece é "Septimus Warren Smith, aged about thirty, pale-faced, beak-nosed", em Manhattan Transfer são outros os recursos narrativos que precisam dar conta da transmissão de informações. Para revelar a biografia das personagens e "suprir" a ausência do narrador, por exemplo, é o diálogo que cumpre essa função por meio de dois aspectos

\footnotetext{
219 ZOLA, Émile. Do romance, cit., p. 98.

${ }^{220}$ É preciso enfatizar, ainda uma vez, que o romance não é homogêneo: assim como há casos no presente, embora a maior parte da narração seja no simple past (variação que parece mais resultado de certo descuido do que um projeto consciente), também o discurso indireto livre reaparece aqui e ali durante a narrativa.

${ }^{221}$ WOOLF, Virginia. Mrs. Dalloway. Oxford: Oxford University Press, 2009, p. 12.
} 
complementares. O primeiro é o conteúdo explícito das falas das personagens, que pode oferecer, imediatamente, dados sobre as trajetórias individuais. É durante o diálogo com Congo e Emile que o leitor descobre, por exemplo, um pouco sobre a vida do velho garçom Marco - que aparece em duas cenas na primeira parte, mas que não reaparecerá mais no decorrer da narrativa ${ }^{222}$. A forma de estruturação dos diálogos dispõe, porém, de um segundo aspecto capaz de revelar os dados biográficos não explicitados pelo narrador: a representação da dicção, do aspecto fônico da linguagem, que costuma, em Manhattan Transfer, caracterizar imigrantes de dentro ou de fora dos Estados Unidos.

\subsection{Ruídos}

Para dar conta desse denso universo que a sua narrativa pretendia expor, Dos Passos aproveitou a convenção de representação fonética, tão comum no realismo estadunidense $^{223}$. O objetivo imediato da representação do "aspecto fônico", afeito ao propósito do projeto artístico do autor (elaborar uma crônica desse universo plural que era a vida cosmopolita de Nova York), seria representar a diversidade sonora característica de um centro metropolitano. No caso de Manhattan, em especial, a diversidade de origens e idiomas é um dado característico desde o início de sua colonização. Por volta de 1638, o pequeno entreposto comercial conhecido como Nova Amsterdam era uma "coleção de oitenta ou noventa estruturas ocupadas por cerca de quatrocentas pessoas" e, nas ruas, ouvia-se não menos do que "dezoito idiomas diferentes" $" 224$. Na metade do século XIX, uma forte corrente de imigração fez com que a chegada de estrangeiros e a coexistência de diferentes idiomas e sotaques se tornasse ainda mais habitual. Em vinte anos, entre 1840 e 1860, entravam pelo porto da ilha, chamada Nova York já desde 1664, uma média de 157 mil imigrantes por ano - número que subiu para duzentos mil entre 1865 e 1873 . O ano de 1854 representou um marco na história da imigração do século XIX, quando, pelo porto de

\footnotetext{
222 "Listen, before I leave Torino when I go last time to see mama I go to a meetin of comrades..." DOS PASSOS, John. Manhattan Transfer, cit., p. 32.

${ }^{223}$ Trata-se de um procedimento comum na tradição estadunidense e que pode ser rastreado pelo menos desde o início do realismo, por exemplo em Life in the iron-mills, de Rebecca Harding Davis (1861). Ou, ainda antes, em Moby Dick. John Dos Passos comenta, em uma entrevista de 1969, sobre a influência dessa técnica a partir de Stephen Crane: "I admired (...) Stephen Crane, particularly 'Maggie, Girl of The Streets', in which Crane has a terrible good ear for conversation and the way people put things". DOS PASSOS, John. John Dos Passos - interview by David Sander (1962). In: PIZER, Donald (Org.). John Dos Passos: the major nonfictional prose. p. 244

${ }^{224}$ BURROWS, Edwin; WALLACE, Mike. Gotham, cit., p. 30-31.
} 
Manhattan, foi admitido um número de imigrantes superior à população da cidade: 319 mil irlandeses, alemães, ingleses, entre outras nacionalidades, fizeram Nova York atingir, em 1860, mais de um milhão de habitantes, tornando-se tão populosa quanto Paris $^{225}$. Com um salto de 500 mil habitantes em 1850 a 3.437 .202 milhões na virada do século, dos quais mais de um terço era imigrante, é compreensível que, para Dos Passos, fosse fundamental criar um efeito no livro que aproximasse o leitor da vivência ruidosa dessa cidade cosmopolita, marcada pela convivência de imigrantes das mais variadas origens ${ }^{226}$.

Justificada a necessidade histórica de incluir no plano da representação literária a diversidade sonora da cidade, o primeiro problema suscitado por essa opção reside no fato de que o uso dessa convenção de grafia fonética pode gerar certa sensação de artificialidade no texto. Ou seja, em vez de, pela mimese fonética, acentuar o efeito de imersão na realidade cotidiana (o que poderia ocorrer, por exemplo, pelo uso de uma sintaxe e um vocabulário apropriados para os círculos sociais e classes econômicas em que estão inseridas certas personagens), esse tipo de elaboração provoca um estranhamento, produzindo uma interrupção na leitura, e remete o leitor ao caráter fabricado do texto. O segundo problema é resultado da tensão gerada quando, ao lado da praxe artificial da transcrição fonética da fala de algumas personagens, a convenção da norma culta é utilizada para registrar a fala de outras, principalmente daquelas que, ou foram criadas em Manhattan (Ellen), ou possuem uma posição social mais consolidada, seja por formação intelectual (Jimmy, Baldwin), seja por posição econômica (os Merival). A oposição provocada pela exploração literária do sotaque - não apenas de imigrantes mas também de personagens do interior - sugere, por oposição, uma norma da qual a sua fala se desvia. Um exemplo claro pode ser observado, ainda no décimo sétimo trecho transcrito (página 101), em que há uma diferença entre a grafia da fala de Bud e a do estranho ao qual ele se dirige. Enquanto a pronúncia de Bud é marcada foneticamente

\footnotetext{
${ }^{225}$ BURROWS, Edwin; WALLACE, Mike. Gotham, cit., p. 1.111.

${ }^{226}$ Até mesmo os ruídos físicos das máquinas acabam irrompendo no romance, interrompendo conversas: "'You'd better look out if he sets his lamps on you Jimmy.' 'Why?' 'Strange fish, Jimmy, strange fish.' An Elevated train shattered the barred sunlight overhead. He could see Ruth's mouth forming words. 'Look,' he shouted above the diminishing clatter. 'Let's go have brunch at the Campus and then go for a walk on the Palisades.' 'You nut Jimmy what's brunch?'” DOS PASSOS, John. Manhattan Transfer, cit., p. 114. Nessa cena, Ruth e Jimmy saem para almoçar e é justamente no momento em que Ruth explicaria o motivo pelo qual Jimmy deveria ter cuidado ao se aproximar de Ellen que o barulho do trem correndo os trilhos do elevado sufoca a sua voz. Nem Jimmy, nem os leitores sabem, por fim, o que ela diria.
} 
na escrita, a fala de seu interlocutor é grafada segundo a norma ortográfica. Contudo, ao contrário do que poderia ocorrer, o efeito geral não parece recair principalmente sobre "falhas" de sintaxe ou de gramática, mas apenas para descrição fonética. Acreditamos que algumas características do texto evitam que o uso dessa convenção fonética se torne apenas um dado de exotismo, mas opere, ainda que artificialmente, como meio para estabelecer um universo plural no interior do romance.

O primeiro fator é a configuração do narrador onisciente, neutro e sem marcas autorais: a impessoalidade impede que a sua voz se torne um ponto de referência, a norma do texto. Em segundo lugar, o uso recorrente desse mecanismo para dar voz sobretudo às personagens originalmente de fora da metrópole não determina a sua feição nem anula o seu elemento humano. Por caracterizar acima de tudo a pronúncia, e não erros gramaticais, a narrativa também atenua o sentimento de exotismo e cumpre uma função fundamental, que decorre, mais uma vez, da reserva do narrador: é pela expressão da dicção das personagens que sabemos a sua origem. Vejamos como.

No trecho transcrito na página 102, em que Marco, Emile e Congo tomam café da manhã após o fim do expediente, o garçom cobra dos três imigrantes que estes falem inglês - Dos Passos soube acentuar as nuances da imigração neste episódio, porque percebemos que o garçom é, ele mesmo, não só "um” imigrante, mas um irlandês. Ou seja, pertence a um dos grupos que, historicamente, mais sofreu preconceito e encontrou dificuldades em sua assimilação. Já que o narrador, recusando-se a assumir a posição de comentador, não explica a sua origem, é apenas a mimese fonética da pronúncia que nos permite descobri-lo - efeito que se repete ao longo de todo o romance. É também o sotaque da personagem que compra a lâmina de barbear no fim do primeiro capítulo que complementa os outros elementos descritivos e permite ao leitor supor que se trata, portanto, de um judeu.

Se a configuração desse narrador joga com as lacunas na exposição das intrigas do romance - parcialmente compensadas, como vimos, por alguns recursos narrativos -, ela também tem consequências para a composição das próprias personagens. A sua descrição é elaborada a partir do acúmulo e da repetição de alguns poucos elementos específicos e característicos, que podem variar de enfoque (ora um traço físico, ora um aspecto de suas vestimentas), mas que não exaurem o objeto representado. A personagem de Bud, por exemplo, é caracterizada principalmente pela precariedade de suas roupas. No primeiro trecho transcrito, no início desse 
capítulo, os velhos sapatos surrados pela caminhada ("road-swelled shoes") e as mangas puídas ("frayed sleeves”) traçam o desenho da personagem, complementado pelo magro pescoço de peru e os punhos vermelhos. Essa descrição reaparece, dois capítulos adiante, quando uma senhora observa a sua barba por fazer e nota os seus pulsos que caíam, grosseiros, das mangas puídas ("wrists that hung raw below the frayed sleeves of his coat" ${ }^{, 22}$ ). Outras personagens do romance são relacionadas a apenas um elemento, como o arruinado e friorento Sr. Densch, caracterizado apenas por seus "tortoiseshell spectacles"228, ou a partes do corpo, como o "longnosed Jewish boy" 229 que divide a limpeza das louças com Bud em um emprego tedioso e mal pago que ele consegue arranjar.

As personagens são, portanto, fragmentos nos quais o narrador foca $\mathrm{e}$ acompanha de forma descontínua e imprevisível. Assim como vemos uma miríade de cacos de vida de "figurantes" que aparecem, mas que não retornam à cena, também as tramas de personagens como Ellen, Jimmy e Baldwin são fragmentadas, e os eventos mais decisivos pelos quais as personagens passam, em geral, não nos são transmitidos. Ao contrário, ao leitor são oferecidas apenas cenas em que são exploradas as consequências dos grandes acontecimentos. Dessa forma, como um princípio geral de construção que age sobre a macroestrutura da narrativa e sobre a exposição fragmentária das tramas, a montagem afeta também a construção interna das próprias personagens.

\title{
3.4 "Abaixo a flânerie!"
}

\begin{abstract}
20) As they crossed Fifth Avenue Phil caught sight of a girl in a taxicab. From under the black brim of a little hat with a red cockade in it two gray eyes flash green black into his. He swallowed his breath. The traffic roars dwindled into distance. She shant take her eyes away. Two steps and open the door and sit beside her, beside her splenderness perched like a bird on the seat. Driver drive to beat hell. Her lips are pouting towards him, her eyes flutter gray caught birds. "Hay look out..." A pouncing iron rumble crashes down on him from behind. Fifth Avenue spins in red purple spirals ${ }^{230}$.
\end{abstract}

\footnotetext{
${ }^{227}$ DOS PASSOS, John. Manhattan Transfer, cit., p. 54-55.

228 "Says Densch in a deep voice, taking his tortoiseshell glasses out of a case and applying them hurriedly to his nose"; "Densch bald and round as a billiardball sits in the deep armchair playing with his tortoiseshell spectacles." DOS PASSOS, John. Manhattan Transfer, cit., p. 245 e 277 , respectivamente.

${ }^{229}$ DOS PASSOS, John. Manhattan Transfer, cit., p. 36.

230 "Conforme eles atravessavam a Quinta Avenida, Phil vislumbrou uma mulher em um táxi. Por debaixo da aba preta de um chapeuzinho com um penacho vermelho dois olhos cinzas luziram verde
} 
Phil Sandbourne, a personagem central desse trecho, é um arquiteto cuja vida aparece em três breves retalhos distribuídos ao longo do romance. Em dois deles, Phil parece ser apenas mais uma figura que orbita a trama de Baldwin: no primeiro, é com ele que o jovem advogado celebra a conquista de sua primeira grande ação; no último, é ele quem menciona as fofocas que correm pela cidade sobre o interesse de Baldwin pela jovem atriz de "Zannia Girl", Ellen. O fragmento intermediário, que se situa curiosamente também mais ou menos no meio do romance, tem Phil como personagem principal e um amigo, que não reaparecerá, Hartly. O interesse no trecho ora transcrito reside na relação entre o conteúdo (que aborda, explicitamente, a relação do indivíduo com o espaço veloz da metrópole) e a sua composição textual, o que pode nos ajudar a demonstrar como aparece no texto a tensão entre indivíduo e metrópole. A leitura revela como esse excerto expressa, por um viés temático, uma espécie de contraposição que se desdobra no próprio arcabouço formal do romance. Isto é, a relação de forças entre o espaço coletivo (que, não esqueçamos, dá título ao romance) e o indivíduo ganha corpo no antagonismo entre a representação do devaneio de Phil (que percorre a Quinta Avenida imerso em divagações suscitadas pela visão de uma mulher ${ }^{231}$ ) e a violência do princípio de funcionamento da cidade, expressa por meio do discurso que se impõe, interrompendo o percurso individual tanto do devaneio quanto da vida antagonismo que, conforme dito, configura-se na própria construção do enunciado. Sintaticamente, os enunciados da personagem são marcados pelo uso do discurso indireto livre ("She shant take her eyes away"). É por meio desses recursos estilísticos que as frases parecem adquirir certo lirismo ao estabelecer, por exemplo, uma aproximação entre a mulher de olhos cinzas e pássaros (flutter, birds). A elaboração mimetiza a intensidade crescente do sonho ("two steps and open the door and sit beside her”) e a forma de exposição é interrompida por um grito seguido de uma sentença que rompe a forma anterior (“A pouncing iron rumble crashes down on him from behind”). Em outras palavras, o texto expressa uma forma de oposição entre a metrópole e o

preto nos seus. Os rugidos do trânsito diminuem à distância. Ela não deve afastar os olhos. Dois passos e abrir a porta e sentar ao seu lado, ao lado da esplendiosidade empoleirada como um pássaro no banco. Motorista pé na tábua. Os lábios dela fazendo bico pra ele, seus olhos batem pássaros cinzas aprisionados. 'Ei cuidado...' Um ronco veloz de ferro bate nele por trás. A Quinta Avenida gira em espirais vermelho-roxas”. DOS PASSOS, John. Manhattan Transfer, cit., p. 144.

${ }^{231}$ Aqui, a personagem não parece atraída pela imagem do outro, como alteridade. Parece, principalmente, embasbacada pela imagem consumida como mercadoria. E mesmo a atitude do basbaque é colocada em risco pela força aniquiladora da metrópole. 
indivíduo quando a secura da realidade urbana, na forma de um automóvel, põe termo ao devaneio. É, portanto, explicitamente tematizada, nesse trecho, uma oscilação entre dois polos que se desdobra ao longo de todo o romance: aqui, metrópole e Phil; em todo o livro, a metrópole e os indivíduos.

Não é difícil notar, contudo, que se trata também de uma forma sutil de ironizar o pendor sentimental da personagem: o uso do verbo shant (shall not) e do termo splenderness expressam, ao mesmo tempo, a inclinação amorosa da personagem e a distância que existe entre esse sentimento e a posição do narrador. Seja como for, o trecho trata justamente da interrupção brusca da tentativa de enlevo poético. Essa cena, que mobiliza a imaginação do leitor, desdobra-se na sintaxe do trecho e reitera o modo de operação da montagem, reforçado em cada segmento do romance, que interrompe, pela cesura brusca, o desenvolvimento e aprofundamento das partes. Se havia qualquer dúvida sobre a possibilidade da existência de um flanêur, embebido na imagem de uma passante, esse trecho também põe termo a ela. O mote de Taylor (“Abaixo à flânerie" ${ }^{, 232}$ ) ganha, aqui, uma materialidade dura como aço.

O princípio estilístico do romance se desdobra, portanto, também nesse pequeno fragmento, que interrompe o devaneio, e na estrutura descontínua da construção das tramas, já discutida. A forma descontínua concretiza, por meio da montagem, essa interrupção da trajetória individual das personagens, fazendo com que o espaço urbano se torne o agente que retalha os enredos: há lacunas nas histórias, passagens de pouca importância, situações que ficam sem resolução. Os trechos em que vemos Phil são significativos, porque a única coisa que os une é a imagem idolatrada do arquiteto Specker (que reaparece nos três fragmentos) e o seu entusiasmo pela arquitetura e engenharia. Contudo, se um deles fosse simplesmente suprimido, em nada afetaria estruturalmente os outros dedicados a Phil. O impacto que a ruptura brusca entre os fragmentos tem na construção das próprias personagens, frustrando o processo de acúmulo que deveria ocorrer no desenvolvimento individual das tramas, foi alvo frequente da crítica, que censurava na obra as suas figuras planas, carentes de desenvolvimento mais profundo ${ }^{233}$. Quando Edmund Wilson resenhou o primeiro volume da trilogia U.S.A., ele não deixou de notar a diferença em relação à Manhattan

\footnotetext{
${ }^{232}$ Ver BENJAMIN, Walter. Flâneur. In: capitalismo. São Paulo: Brasiliense, 2000.

${ }^{233}$ Por exemplo, na resenha de Bernard De Voto, o crítico argumenta que a falha do livro é simples e reside no fato de que "as personagens não são suficientemente vivas para despertar as simpatias de alguém”. DE VOTO, Bernard. John Dos Passos: Anatomist of Our Time (1936), cit., p. 126.
} 
Transfer, no qual as personagens seriam "vistas de fora e, consequentemente", mal pareceriam humanas $^{234}$.

Ellen, uma das personagens que mais reaparece durante o romance, não escapou das críticas. Talvez devido à constância da sua presença, contudo, é uma personagem que o leitor consegue observar com maior empenho. Testemunhamos Ellen compreender que não pode ser um menino e descobrir quais as implicações sociais dessa limitação; vemos a sua animação (quando criança, com o teatro; depois, durante o seu envolvimento com Stan) esfriar paulatinamente, tornando-se contenção e indiferença. O seu percurso é, como o de Jimmy, mais claro ao leitor. Em um romance em que raras personagens possuem "memórias verdadeiras"235, Jimmy e Ellen - também Baldwin, mas em menor escala - se destacam, pois ao leitor é concedida a oportunidade de acompanhar uma parte do desenvolvimento de suas vidas. A imagem de Ellen, que o leitor constrói a partir de alguns cacos que vislumbra desde o primeiro capítulo, é montada não apenas por meio de suas (re)ações mas também da estranha forma como se organiza a representação da esfera emocional da personagem.

\subsection{Máquinas de fantasmagorias}

21) Once out on Broadway again she felt very merry. She stood in the middle of the street waiting for the uptown car. An occasional taxi whizzed by her. From the river on the warm wind came the long moan of a steamboat whistle. In the pit inside her thousands of gnomes were building tall brittle glittering towers ${ }^{236}$.

Depois de um encontro com Stan, Ellen retorna para a rua 105, onde mora na pensão de Mrs. Sunderland e, para expressar o sentimento vívido que a arrebata, aparece essa sugestão de uma imagem, um tanto surrealista, de gnomos construindo torres frágeis e cintilantes. O primeiro elemento que chama a atenção nesse quadro é a ideia de uma torre em construção. Nos Estados Unidos, os anos após a Guerra Civil marcaram um desenvolvimento técnico sem precedentes ${ }^{237}$. Isso se expressava na

\footnotetext{
${ }^{234}$ WILSON, Edmund. Review (1930), cit., p. 84.

${ }^{235}$ MOREL, Jean-Pierre. John Dos Passos: Manhattan Transfer, cit., p. 83.

236 "Quando saiu na Broadway de novo ela se sentiu muito alegre. Ela ficou no meio da rua esperando o carro pro norte da cidade. Ocasionalmente um táxi zunia por ela. Do rio no vento quente vinha o gemido longo do apito de um barco a vapor. No buraco dentro dela milhares de gnomos estavam construindo altas torres quebradiças e cintilantes." [Tradução nossa.] DOS PASSOS, John. Manhattan Transfer, cit., p. 130.

237 "America was now competing with the great industrial nations, Britain and Germany, and was outstripping both combined.” LEE, Brian; REINDERS, Robert. A perda da inocência: 1880-1914, cit., p. 179.
} 
própria transformação da paisagem do país para além da grande cidade, com o avanço das estradas de ferro, das linhas telegráficas, dos encanamentos cortando o solo, das máquinas nas fazendas ${ }^{238}$. A cidade, que é nosso interesse aqui, era sem dúvida o espaço onde essa transformação se deu de forma mais radical e o aço era o grande emblema da expansão industrial da nação ${ }^{239}$. A torre que se ergue nesse vazio assemelha-se ao elevador com o qual, pouco adiante, Ellen fantasiará, ao imaginar a possibilidade de se tornar "o grande sucesso da Broadway":

21) Greatest hit on Broadway. The words were an elevator carrying her up dizzily, up into some stately height where electric light signs crackled scarlet and gold and green $^{240}$.

Torres cintilantes, elevadores, letreiros luminosos. Esses elementos, recorrentes nas cenas de Ellen, indicam uma receptividade a imagens e um vocabulário que era recente na virada do século. Basta apontar que, na primeira parte do romance, temos carroças atravessando as ruas em diversas cenas, enquanto o carro motorizado aparece apenas em uma, como uma novidade que aterroriza a multidão:

22) At the next corner a crowd was collecting round a highslung white automobile. (...)

A woman with her hair done up in a tight bunch on top of her head was screaming, shaking her fist at the man on the car, "Officer he near run me down he did, he near run me down". (...)

"Wassa matter?"

"Hell I dunno... One o them automobile riots I guess" 241.

São incorporadas à construção da personagem, portanto, referências a esse mundo metropolitano recente e ainda espantoso, e isso é específico no caso de Ellen. É como se essa atriz da Broadway (um dos símbolos mais vívidos dessa época) tivesse certa homologia com o espaço no qual está inserida. Ou, ainda, como se essa grande entidade da obra, Manhattan, dominasse a personagem. E essa "conquista" da esfera subjetiva pelos elementos objetivos da realidade também se revela por meio de outro elemento da cena analisada, os gnomos. Talvez mais evidente para os leitores da

\footnotetext{
${ }^{238}$ A dimensão do impacto das transformações da industrialização pode ser imaginada a partir do seguinte dado: "Before the Civil War it took 61 hours of labor to produce an acre of wheat. By 1900, it took 3 hours, 19 minutes". ZINN, Howard. A people's history of the United States..., cit., p. 253.

${ }^{239}$ LEE, Brian; REINDERS, Robert. A perda da inocência: 1880-1914, cit., p. 179.

240 "Maior sucesso da Broadway. As palavras eram um elevador carregando-a pra cima atordoada, pra cima até alguma majestosa altura onde letreiros de luzes elétricas crepitam escarlate e dourado e verde.” [Tradução nossa.] DOS PASSOS, John. Manhattan Transfer, cit., p. 130.

241 "Na próxima esquina uma multidão estava se juntando em volta de um carro branco do tipo alto. (...) Uma mulher com o cabelo preso num coque apertado no alto da cabeça estava gritando, sacudindo o punho pro homem no carro, 'Policial ele quase me atropelou foi, ele quase me atropelou.' (...) 'Que que houve' 'E eu sei lá... Uma dessas revoltas contra os automóveis"'. [Tradução nossa.] DOS PASSOS, John. Manhattan Transfer, cit., p. 21.
} 
época, os gnomos dessa cena fazem referência a uma propaganda que aparece em outras cenas de Ellen: o anúncio dos chicletes Wrigley’s (que existem ainda hoje).

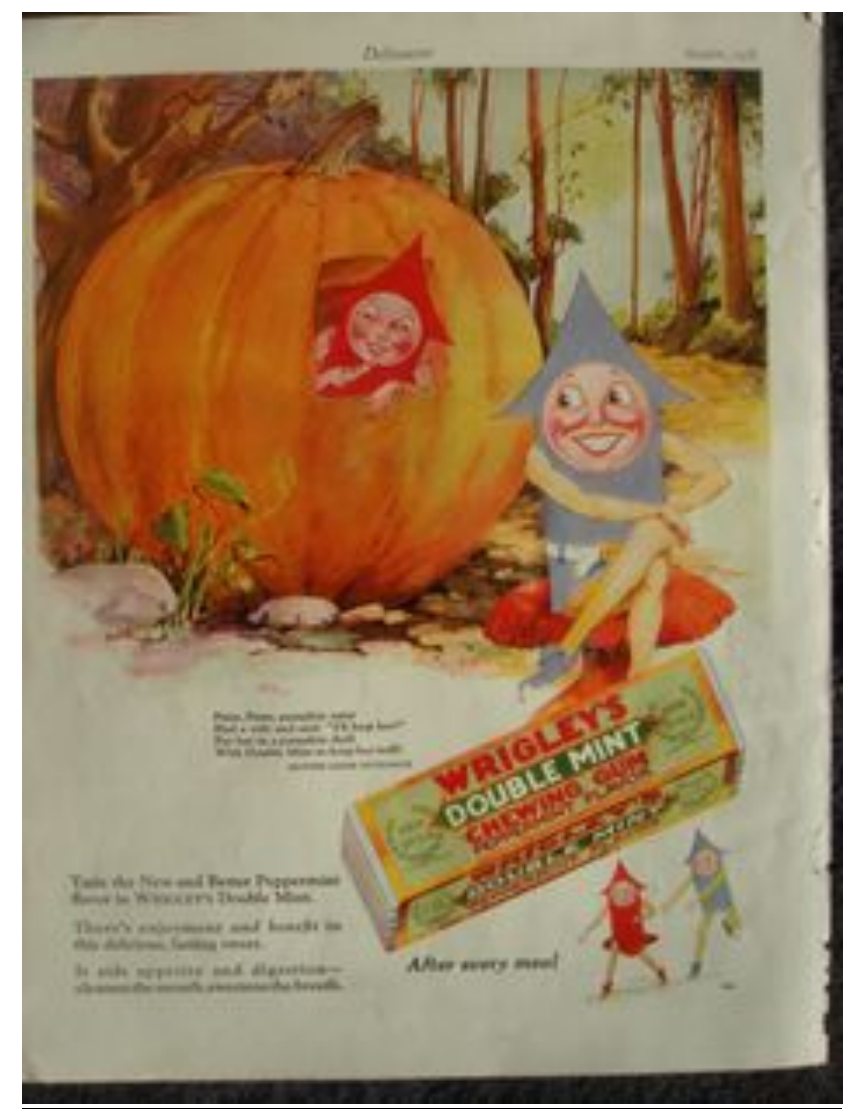

Figura 6 - Propaganda de Wrigley's de 1928

Ellen vê a propaganda dos “gnomos” do Wrigley's (criados em 1907) quando está no trem em sua viagem para a lua de mel, sente o cheiro da goma de mascar quando sobe no ônibus para atravessar a cidade e um cartaz do produto também é mencionado em uma conversa ao fim do romance. É essa repetição explícita que permite associar esses “gnomos”, mencionados fora de contexto, à propaganda ${ }^{242}$.

Assim como ocorre com as imagens da industrialização no caso da torre, os gnomos da propaganda explicitam a ação da publicidade sobre o universo de desejo do sujeito, a ação do mundo do consumo na esfera emocional das personagens ${ }^{243}$. $\mathrm{O}$

\footnotetext{
${ }^{242}$ Para termos uma ideia de como a marca era famosa, quando estava viajando por Damasco em 1922, Dos Passo recebeu uma carta parabenizando-o pelo sucesso de seu romance Three soldiers. Na carta, seu amigo Jack Lawson comentava que, com a publicação do romance "You [Dos Passos] are as famous as Wrigley's". LUDINGTON, Townsend. John Dos Passos: a twentieth century odyssey, cit., p. 213.

${ }^{243} \mathrm{Na}$ própria época, isso já era discutido. No artigo de Matthew Josephson, "The Great American Billposter", Josephson argumenta como "words, expressions, names, become nationally, know and
} 
primeiro momento em que essa questão é elaborada no romance é na propaganda da Gillette. Nela, vemos o estrangeiro barbudo confrontado pela propaganda de uma lâmina de barbear da marca Gillette. A potência dessa cena reside no fato de que ela é capaz de expressar dois vetores fundamentais na publicidade, campo de trabalho que ganhou importância após 1880 como mercado. O primeiro vetor é a criação de desejos do indivíduo - a partir, é claro, do reconhecimento de um potencial latente. No caso da propaganda em questão, o que está em jogo é o desejo de alcançar uma posição de sucesso que garanta a integração venturosa na sociedade. Esse desejo existe de modo latente em uma sociedade com tamanha afluência de imigrantes e, se não foi ainda experimentado por um indivíduo particular (por exemplo, um estrangeiro que caminha pela cidade), o papel da publicidade é justamente criar esse desejo em cada indivíduo por meio de uma imagem. O segundo vetor que fica explícito por essa cena é o de que a propaganda, ao mesmo tempo em que cria (ou reafirma) o desejo, também promete a sua realização por meio da representação pictórica do triunfo estampado no rosto do King C. Gillette.

Embora o episódio já discutido da lâmina de barbear Gillette seja bastante significativo, os fragmentos da história de Ellen são um campo privilegiado para observar o nexo que a narrativa estabelece entre as propagandas e a esfera subjetiva das personagens. Uma das figuras mais reincidentes de Manhattan Transfer, Ellen é acompanhada pelo leitor desde o seu nascimento até, atravessando largas elipses, a sua ascensão social como editora de uma revista de moda e o seu casamento com George Baldwin. Sabe-se que Dos Passos escreveu cada um dos enredos paralelos separadamente - cada um em sua totalidade - para depois montá-los em justaposição uns aos outros, aos episódios isolados e às colagens. Sabemos também que, enquanto elaborava separadamente o enredo de Ellen, Dos Passos a associou à personagem Tess Durbeyfield, de Thomas Hardy. Segundo Linda Wagner revelou a partir de sua pesquisa nos arquivos da Universidade da Virgínia, um dos títulos que Dos Passos

enter into the daily speech. These experiences are received with varying degrees of directness: sometimes the facet that 'United States Tires are good tires' is merely refracted into the brain by a series of repercussions, and lodges there with the other legends in a distinct layer of the consciousness". JOSEPHNSON, Matthew. The Great American Billposter, cit., p. 306. É interessante que Josephson publique esse artigo justamente na Broom, cuja primeira edição conta com um artigo de Emmy Veronica Sanders, em que a crítica recai justamente sobre as revistas que "exportariam" aos países europeus, não as melhores obras da produção nacional, mas "panting, tonguelolling, moviemovie, electrically lighted braininess; true offspring of its parent, the Machine". SANDERS, Emmy Veronica. America invades Europe, cit., p. 91. Para mais informações sobre o assunto, ver NORTH, Michael. Transatlantic transfer, cit. 
cogitou escolher para o romance era "Tess of the 48th Street or The Story of a Pure Woman"244. Para a pesquisadora, Dos Passos considerava Ellen, de forma similar à Tess, uma vítima das mudanças dos valores morais em uma sociedade em rápida transformação. Como sintoma dessas transformações, cada uma das relações que a personagem estabelece representaria um novo passo para abalar as estruturas emocionais, já pouco sólidas, de Ellen.

Sem dúvida, assim como vemos nas tramas de outras personagens de Manhattan Transfer, Ellen parece ser apenas capaz de reagir às forças sociais, concretizadas na configuração ficcional da metrópole. O tema da impossibilidade de ação é recorrente no livro e perpassa também a narrativa de Jimmy:

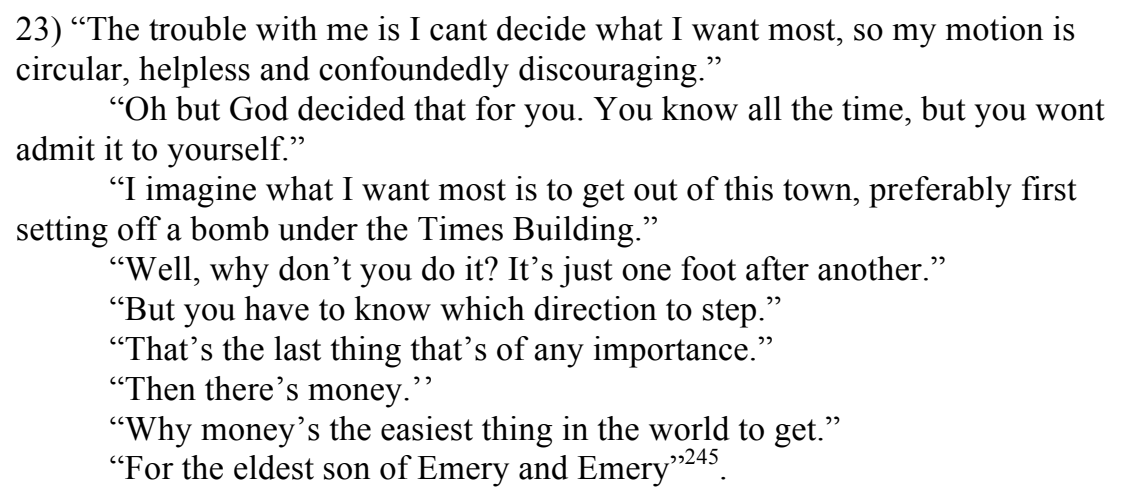

Esse é um diálogo paradigmático: a ausência de ação de Jimmy é explicitada, e a consciência que ele possui de seu estado, em vez de possibilitar uma transformação, implica também a sua imobilidade. A imobilidade, contudo, não é algo que aparece na trajetória de Ellen desde o princípio do romance. Note-se o ímpeto inicial de Ellen ao romper o casamento com Jojo. Há algo do vaudeville nas cenas protagonizadas por seu ex-marido, "a rather tragic person", como diz a própria Ellen. Nos esquetes improvisados desses atores e atrizes que vivem sempre à espera de algum sucesso, Ellen desponta repetidamente um tanto aborrecida e indiferente. É o acaso que a aproxima de Stan e abre uma janela de oportunidade de transformação em sua vida. Disposta a arriscar reputação e, talvez, carreira, Ellen abre um processo judicial de divórcio. Em um impulso digno de um herói convencional de romance, ela

\footnotetext{
244 "Tess da rua 48 ou "A história de uma mulher pura."”

245 “'O problema comigo é que eu não consigo decidir o que eu mais quero, então meu movimento é circular, impotente, e confusamente desencorajador'. 'Ah, mas Deus decidiu por você. Você sempre soube disso, mas não quer admitir'. 'Acho que o que eu mais quero é sair dessa cidade, de preferência armando uma bomba embaixo do prédio da Times'. 'Bom, e por que não faz isso? É só dar um passo depois do outro'. 'Mas você tem que saber em qual direção andar'. 'Essa é a coisa que menos importa.' 'E tem o dinheiro'. 'Como assim? Dinheiro é a coisa mais fácil de se arranjar.' 'Pro filho mais velho de Emery \& Emery.’” DOS PASSOS, John. Manhattan Transfer, cit., p. 149.
} 
parece determinada a dispor em alguma medida de seu futuro, fazendo uma opção que nada lembra o cálculo que, segundo a fofoca no círculo do teatro, orientou o seu casamento com Jojo. O suicídio de Stan, contudo, marca o início de uma história de imobilidade progressiva.

Se podemos, conforme Linda Wagner, argumentar que Ellen, assim como Tess, é uma vítima da estrutura social na qual está inserida, é impossível não imaginar que houvesse uma ponta de ironia nesse título que Dos Passos imaginou para o seu enredo. Afinal, manter o subtítulo do romance vitoriano "pure woman" em um contexto como o de Ellen gera atritos e ruídos que certamente não passaram desapercebidos por Dos Passos.

Ellen, na verdade, parece uma parente muito mais próxima e desiludida da Carrie sonhada por Theodor Dreiser ${ }^{246}$. As duas personagens, separadas por vinte e cinco anos de intenso desenvolvimento industrial e comercial, fazem parte de um tipo urbano muito significativo. Em seus escritos sobre a metrópole, Robert E. Park sugeria que os pesquisadores estudassem alguns tipos "vocacionais" que eram "produtos característicos das condições da vida urbana"247. A vendedora de grandes lojas, o taxista, o fura-greves, o agitador político - a esses tipos Park deveria ter incluído as mulheres que brilhavam sob os holofotes da Broadway. A história dessas coristas, de mulheres que, por uma mistura imprecisa de sorte e talento, tornam-se grandes atrizes nos palcos de Nova York, era um tema caro à própria indústria do entretenimento. Um dos motivos mais comuns das peças musicais da época de Dos Passos retratava a Broadway como a "quintessência da meritocracia" nos Estados Unidos, pois era lá que "os sonhos de avanço feminino poderiam ser realizados"248. Tanto Carrie quanto Ellen ascendem socialmente por meio de uma carreira no teatro, embora o sucesso profissional e econômico pareça, em ambos os casos, não cumprir todas aquelas promessas de realização individual que deveriam, a princípio, garantir. O fato de que a desilusão e o possível cinismo, em Manhattan Transfer, serem tão mais agudos do que em Sister Carrie tem, para Paula Geyh, raízes em uma diferença

\footnotetext{
${ }^{246}$ BREVDA, William. How do I get to Broadway. Texas Studies in Literature and Language, v. 38, n. 1, p. 85, Spring 1996. Embora Carrie não possa ser tomada como uma personagem ingênua, Ellen realmente transmite certa consciência acerca dos acontecimentos e procedimentos necessários para alcançar algum sucesso em que ela se diferencia de Carrie.

${ }^{247}$ PARK, Robert E. The City: Suggestions for the Investigation of Human Behavior in the City Environment. American Journal of Sociology, v. 20, n. 5, p. 586, Mar., 1915.

${ }^{248}$ GRAHAN, Austin. The great American songbook. Musical texts, modernism, \& the value of popular culture. Oxford; New York: Oxford University Press, 2013, p. 190.
} 
de ordem histórica: cada um dos romances trata de um estágio distinto do capitalismo estadunidense. Enquanto o romance de Dreiser habita um mundo de coisas criado pelo "capitalismo da produção em massa de bens de consumo", a Manhattan de John Dos Passos parece ser uma cidade de signos, muito mais determinada pelo capitalismo "pós-industrial emergente", caracterizado por uma sofisticação acelerada da produção justamente dos meios de propaganda. O grande problema do argumento de Geyh é o de que ela comete um deslize ao situar o romance de Dos Passos nos anos 1920: segundo a autora, o romance teria como assunto "the Roaring Twenties New York". Sabemos, entretanto, que o romance cobre um período de cerca de vinte anos, desde 1896, data da unificação de Nova York, até 1920. Além disso, falar em capitalismo "pós-industrial" antes da década de 1920 é prematuro. Talvez o mais preciso seja dizer que os dois romances enfatizam aspectos diferentes relacionados ao mundo da produção capitalista. O fundamental seria, na verdade, analisar como o desenvolvimento da indústria da propaganda - sem dúvida alguma vinculado ao volume sem precedentes da produção de bens de consumo - ganha destaque no romance de Dos Passos ${ }^{249}$. Em Sister Carrie, a mercadoria é muito mais presente e faz parte do motor de desejos da personagem principal. Desde que chega em Chicago, observa Geyh, Carrie é atraída pelos objetos de consumo expostos que ela, contudo, não tem como comprar - e a sua posição social inferior é constantemente denunciada por suas vestimentas, expondo ao olhar de todos "quem ela é" ${ }^{250}$. A atração exercida pela mercadoria faz com que a própria coisa ganhe voz no romance: os itens dispostos na loja falam diretamente à personagem e suplicam para serem comprados. Ademais, a atração que Druet ou Hurstwood exercem sobre Carrie é também mediada pelas mercadorias que eles exibem (por exemplo, por suas roupas que ostentam um status que Carrie ainda não tem). Conforme pondera Geyh, as mercadorias que são o motor do desejo da personagem funcionam tanto como bem de consumo quanto signo de uma posição social e econômica almejada. Ainda assim, é a lógica do consumo, e não do signo, que é parte fundamental do desenvolvimento do enredo de Dreiser. Como um bem de consumo produzido pela indústria de massa, a mercadoria certamente comparece na Manhattan de Dos Passos, mas são os signos - as propagandas, manchetes de jornal, recortes de letras de canções populares -, acima de tudo, que organizam a esfera do desejo e do sonho.

\footnotetext{
${ }^{249}$ GEYH, Paula. From Cities of Things to Cities of Signs..., cit., p. 414.

${ }^{250}$ GEYH, Paula. From Cities of Things to Cities of Signs..., cit., p. 418-419.
} 
Em seu estudo sobre a representação de Nova York na virada do século, Douglas Tallack observa que, em 1914, a cidade já era responsável por 10\% de toda a produção nacional de manufatura (principalmente na confecção de roupas e chapéus e lapidação de pedras preciosas). Esse número aumentou exponencialmente até 1919, quando subiu para $50 \%$ e, a partir daí, algumas fábricas começaram a deixar as regiões centrais de Manhattan e se espalhar pelos outros bairros da cidade. Para Tallack, a informação é significativa porque contrasta com a reduzida representação dos ambientes de produção na cultura visual de Nova York. Tallack argumenta que o crescimento econômico se cristalizou em duas imagens da metrópole. Em primeiro lugar, gerou um "mundo de produtos de consumo, uma arena na qual eles poderiam ser expostos", e isso é o que vemos em Sister Carrie. Em segundo lugar - o que marcou de forma definitiva a cidade de Nova York -, gerou uma "fase em que o objeto que foi produzido para ser vendido e usado entra em seu estado mais insubstancial, como signo: ele acaba, na verdade, sendo feito do mesmo material das formas de representação que o registram" ${ }^{251}$.

A crítica especializada já se debruçou longamente sobre a importância e os desdobramentos, na história de Ellen, da aparição da famosa "Danderine Lady" - uma mulher de branco, a cavalo pela cidade, que personificava a propaganda de uma mercadoria, uma espécie de loção muito popular na época que prometia o crescimento de cabelos e a cura de caspa. No romance, a figura se autonomiza do conteúdo material a que deveria estar associada (o xampu) e cria, para a personagem de Ellen, uma imagem espelhada de si mesma ou o retrato de seu desejo. Há ainda mais um desdobramento que aparece na intensa relação da atriz com Stan, para quem a propaganda e a imagem de Ellen se confundem de forma muito representativa. No dia em que os dois futuros namorados se conhecem, Ellen comenta que tinha acabado de ver a "Danderine Lady", a qual a "impressionou enormemente".

\footnotetext{
${ }^{251}$ TALLACK, Douglas. New York sighs. Visualizing old and new New York. New York: Berg, 2005, p. 19-21.
} 


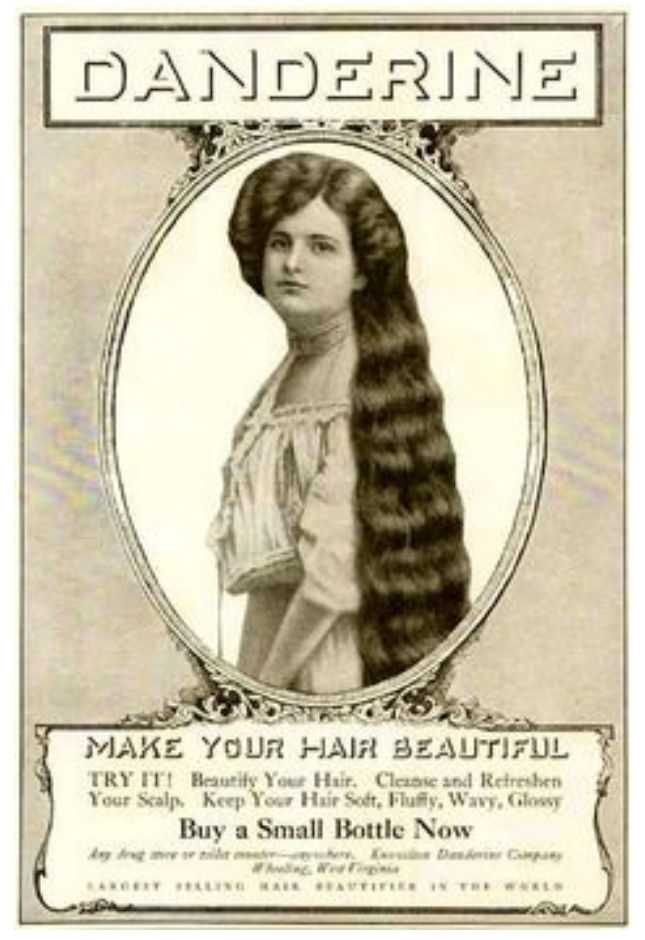

Figura 7 - Propaganda da loção Danderine

A partir de então, o jingle da loção se torna a música que Stan associa a Ellen, adaptando os versos "with rings on her fingers and bells on her toes, and she shall cure dandruff wherever it grows" ${ }^{252}$. Ao fim da segunda parte do romance, na cena em que Stan está delirando pouco antes de morrer, o jingle ressoa, como em "um piano mecânico" $" 253$ :

24) With bells on her fingers and rings on her toes Shall ride a White lady upon a great White horse, and she shall make mischief wherever she goes ${ }^{254}$.

Temos, mais uma vez, uma associação entre os elementos do desenvolvimento técnico e a propaganda: o piano mecânico era uma invenção recente, e a sua inserção aqui para caracterizar o processo mental de Stan enfatiza essa predisposição acentuada para a incorporação dessa nova paisagem tecnológica.

$\mathrm{Na}$ última parte do romance, os gnomos reaparecem ainda uma vez em uma conversa que Anna Cohen escuta por acaso enquanto desce as escadas do edifício onde trabalha: uma garota foi encontrada assassinada atrás de um anúncio dos

\footnotetext{
${ }^{252}$ DOS PASSOS, John. Manhattan Transfer, cit., p. 118.

253 "His mind went on jingling like a mechanical piano." DOS PASSOS, John. Manhattan Transfer, cit., p. 213.

${ }^{254}$ DOS PASSOS, John. Manhattan Transfer, cit., p. 213. Paula Geyh analisa a mediação que a figura da Dandarine Lady estabelece na imagem que Ellen constrói de si mesma e em sua relação com Stan. GEYH, Paula. From Cities of Things to Cities of Signs..., cit., p. 430-431.
} 
chicletes Wrigley's ${ }^{255}$. Em contrapartida à adesão inconsciente de Ellen às imagens do mundo da propaganda, que organizam a representação subjetiva do seu desejo, o narrador, ironicamente, utiliza o anúncio do Wrigley's para marcar dois momentos dramáticos do romance. O primeiro desses eventos é o casamento desprovido de amor, mas bem calculado, de Ellen, lavado pela chuva torrencial que acompanha os seus dias de lua de mel. O segundo é essa notícia de assassinato, ouvida justamente por Anna Cohen, que será vítima de um incêndio no ateliê onde os vestidos de Ellen são confeccionados.

De Carrie a Ellen, transformaram-se alguns elementos dessa relação entre a subjetividade e o mundo do consumo, mas ainda sentimos a presença de uma preocupação cara ao naturalismo: a introjeção das normas sociais e da ideologia dominante $^{256}$. Essa introjeção se dá pela forma como Ellen é caracterizada: um vocabulário afeito às novas tecnologias da época. Como David Harvey argumenta, os Estados Unidos, que não tinham resquícios de uma classe aristocrática ou uma herança feudal, não sentiram de forma rigorosa a força da resistência às transformações operadas pelo avanço da tecnologia. Além desse traço histórico, havia um esforço contínuo de disseminação da ideologia da técnica. As revistas da época, por exemplo, Cosmopolitan, Harper's Weekly, Collier's, The Saturday Evening Post e The Ladies Home Journal, cumpriam o papel de difundir, no cotidiano da classe média, imagens de novos produtos e ideais vinculados ao avanço tecnológico. Enquanto anunciava itens como fonógrafos, bicicletas, fornos, máquinas de lavar elétricas, ferros e uma série de outras novidades, a revista Good Housekeeping, por exemplo, informava a suas leitoras que "uma casa não é nada mais do que uma fábrica para a produção de felicidade" 257 .

Assim como o mundo cotidiano vai sendo alterado pela difusão dos produtos e processos técnicos, o romance demonstra de que modo o inconsciente das personagens também é permeado e transformado pelo mundo objetivo. A própria noção de transformação e renovação opera um dos aspectos mais violentos da trama de Ellen. Encantada pelo mundo do teatro desde pequena, a sua infância (ou o que conhecemos, como leitores, dela) é marcada pela ideia de tornar-se outro. Se durante a infância isso é

\footnotetext{
${ }^{255}$ DOS PASSOS, John. Manhattan Transfer, cit., p. 118.

${ }^{256}$ Ver PEASE, Donald. Psychoanalyzing the Narrative Logics of Naturalism: "The Call of the Wild". Journal of Modern Literature, Global Freud: Psychoanalytic Cultures and Classic Modernism, v. 25, n. 3-4, p. 15, Summer, 2002.

${ }^{257}$ TICHI, Cecelia. Shifting gears. Technology, literature, culture in modernist America. Chapel Hill; London: The University of North Carolina Press, 1987, p. 19.
} 
enunciado de maneira evidente em diversas cenas, na vida adulta está relacionado às mudanças consecutivas de seu nome: Ellen, Elaine, Helena. Não custa lembrar como Ian Watt associa a utilização do nome próprio à ascensão do romance no século XVIII: dedicando esforço à particularização do indivíduo, o nome próprio no romance está associado à ênfase à identidade individual e à memória biográfica ${ }^{258}$. Ao abandonar o seu prenome de nascimento por um novo, é como se Ellen buscasse, por um lado, uma espécie de compensação simbólica, tornando-se, a princípio, aquilo que deseja ser; e, por outro, provocasse um mise en abîme de sua vida de atriz. Trocando de máscaras e esquecendo as personagens, Ellen apaga a sua história conforme muda de estágio na vida. Quando se encanta com o sonho de ser atriz, torna-se Elaine. Essa troca ocorre por volta da época em que, ainda criança, começa a se dar conta de sua posição social e dos limites impostos pelo fato de ser uma menina ${ }^{259}$. Ao fim do romance, após as inúmeras frustrações e de ser tomada por uma espécie de apatia (como veremos adiante em uma cena exemplar), ela passa a ser chamada de Helena.

Em primeiro lugar, podemos sugerir uma homologia entre as transformações de Ellen e o nexo constante da novidade na sociedade capitalista - uma espécie de antecipação do hoje tão corrente "dever de se reinventar". Não por acaso, o nome Helena surge quando ela assume o cargo de editora de uma revista feminina de moda. Essas transfigurações de Ellen representam um emblema desse processo formal de descontinuidade e ruptura, discutido neste e no capítulo anterior, que satura o romance. Esse processo de fratura corresponde à inquietação de Dos Passos em relação à possibilidade de um núcleo biográfico, ou seja, que uma trajetória individual e as relações intersubjetivas a partir dela estabelecidas fossem capazes de expressar os problemas de um espaço social no qual a própria construção do indivíduo estava em xeque - a metrópole da era industrial. Como resultado, a história de Ellen avança, simbolicamente, por uma série de rupturas, implicando esse repetido apagamento da história.

Ellen, Elaine: ao se converter, por fim, na mítica Helena, a atriz concretiza em sua história a impossibilidade de individuação expressa pelo princípio estilístico, na própria forma do romance. Contudo, a Helena de Manhattan não evoca, como no mito, a experiência coletiva da épica - pelo contrário. Se, na verdade, o que vemos é uma

\footnotetext{
${ }^{258}$ WATT, Ian. A ascensão do romance. São Paulo: Companhia das Letras, 1990, p. 19-20.

${ }^{259}$ A cena em que ela exige que a sua amiga Alice a chame de Elaine ocorre pouco antes da conversa com o seu pai, no Battery Park, em que se fala sobre ter mais dinheiro e acerca do que ela não pode fazer por não ser menino.
} 
supressão de sua individualidade, pela recusa em conservar, para si, a memória de sua trajetória, Helena não deve ser analisada nos termos do mito. Nessa cidade em que está inserida, talvez possamos imaginar seu último nome como a marca de um produto. Nessa medida, o slogan da mercadoria (condensado em Helena) reforça a sua presença na trajetória de Ellen. Ao abandonar a sua história, expressando a descontinuidade e a fragmentação que observamos em outros aspectos do romance, Ellen torna-se mais fria, com um rosto severo ("she's right, Ellen was thinking, I am getting a hard look"260), que traz as marcas de um intenso processo de dissociação.

\subsection{Afogamentos}

24) Through dinner she felt a gradual icy coldness stealing through her like novocaine. She had made up her mind. It seemed as if she had set the photograph of herself in her own place, forever frozen into a single gesture. An invisible silk band of bitterness was tightening round her throat, strangling. Beyond the plates, the ivory pink lamp, the broken pieces of bread, his face above the blank shirtfront jerked and nodded; the flush grew on his cheeks; his nose caught the light now on one side, now on the other, his taut lips moved eloquently over his yellow teeth. Ellen felt herself sitting with her ankles crossed, rigid as a porcelain figure under her clothes, everything about her seemed to be growing hard and enameled, the air bluestreaked with cigarettesmoke, was turning to glass. His wooden face of a marionette waggled senselessly in front of her. She shuddered and hunched up her shoulders. (...)

Beyond the shaking glass window of the taxi, like someone drowning, she saw out of a corner of an eye whirling faces, streetlights, zooming nickleglinting wheels ${ }^{261}$.

O trecho é longo, mas vale ser transcrito em sua quase integridade por ser um dos mais densos e expressivos do romance. Ao final do trecho, o afogamento de Ellen remete à imagem da água como dilúvio, constantemente reiterada ao longo do romance, sobretudo relacionada a essa personagem que o leitor vê nascer no primeiro capítulo.

\footnotetext{
${ }^{260}$ DOS PASSOS, John. Manhattan Transfer, cit., p. 336.

261 "Durante o jantar ela sentiu um frio glacial gradualmente deslizando por dentro como novocaína. Ela tinha se decidido. Era como se tivesse colocado uma foto de si mesma em seu lugar, congelada para sempre em um único gesto. Uma invisível faixa de seda de amargura apertava seu pescoço, estrangulando. Depois dos pratos, o abajur de marfim rosa, os pedaços de pão, o rosto dele sobre o peitilho branco balançava e sacudia; o rubor aumentou em seu rosto; o nariz dele refletia a luz de um lado, depois do outro, seus lábios tensos se moviam eloquentemente sobre os dentes amarelos. Ellen sentiu que estava sentada com os tornozelos cruzados, rígida como uma figura de porcelana sob as roupas; tudo à sua volta parecia estar ficando endurecido, esmaltado, o ar azulmanchado com fumaçadecigarro, estava tornando-se vidro. O rosto de madeira de marionete dele meneava sem sentido na frente dela. Ela estremeceu e tensionou os ombros (...) Do outro lado da janela que tremia no táxi, como alguém se afogando, do canto do olhos ela viu rostos rodopiando, postes de luz, rodas brilhandoníquel zunindo". [Tradução nossa]. DOS PASSOS, John. Manhattan Transfer, cit., p. 318319.
} 
Como já foi comentado, no fim da primeira parte do romance, quando Ellen se casa com John Oglethorpe, há uma cena em que, concatenados ao discurso indireto livre, aparecem trechos de uma canção cujo verso anuncia "oh it rained forty days, and it rained forty nights". O motivo da chuva, que acompanha Ellen e reaparece na cena da morte de Stan Emery, finalmente domina a personagem nesse último capítulo. A água marca o romance como uma imagem concorrente à do fogo. Além de ser um dado factual, uma vez que os incêndios eram comuns em Nova York, o fogo aparece como um índice de destruição do horizonte de sonhos e possibilidades das personagens. Isso se exemplifica no primeiro incêndio descrito no livro. Na abertura do segundo capítulo da primeira parte, vimos Ed Thatcher sozinho executando uma divertida pantomima por meio da qual ele vivencia o seu devaneio de ascensão social. A situação que se segue é a de um incêndio em um cortiço (tenement) vizinho contextualização da vida da família Thatcher que serve como forma de explicitar os limites do "sonho americano" - que será, de certa forma, realizado pela filha de Thatcher, mas à custa do afogamento das ilusões de seu pai. Além disso, é um incêndio que consome Stan Emery e, no último capítulo do romance, a costureira Anna Cohen - as duas personagens relacionadas, pelo amor fracassado e o consumo, à Ellen. $\mathrm{O}$ incêndio e a enchente remetem, por meios tortuosos nesse romance, a imagens do apocalipse, o que fez o crítico Roger Mortimer ${ }^{262}$ associar esses elementos que perpassam todo o romance (e que culminam no título do último capítulo, "O Fardo de Nínive") à imagem arquetípica da cidade apocalíptica, presente em muitos autores e pintores cujas obras são congregadas sob o termo “expressionismo”. Essa aproximação, aliás, talvez seja mais pertinente e profícua do que quando Mortimer associa o estilo do romance a estética do movimento futurista. À primeira vista, o dinamismo e a sobreposição de planos de imagens presentes em Manhattan Transfer realmente poderiam remeter à escola futurista - influência sempre explicitada pelo próprio Dos Passos.

25) In the brick houses and the dingy lamplight and the voices of a group of boys kidding and quarreling on the steps of a house opposite, in the regular firm tread of a policeman, he felt a marching like soldiers, like a sidewheeler going up the Hudson under the Palisades, like an election parade, through long streets towards something tall white full of colonnades and stately. Metropolis ${ }^{263}$.

\footnotetext{
${ }^{262}$ MORTIMER, Roger. Mortimer, Roger., "Choreographed accident: John Dos Passos' "Manhattan Transfer" as modernist satire." 1990. 109 f. (Mestrado). Universidade de Windsor, Windsor, Ontario, 1990.

263 "Nas casas de tijolos e lâmpadas sombrias e vozes de meninos brincando e brigando nas escadas da casa da frente, no caminhar firme regular de um policial, ele sentiu um marchar como de soldados,
} 
O trecho transcrito acima é um dos utilizados por Mortimer para comentar o estilo "futurista" da descrição, que se revela também na fusão entre o indivíduo e a metrópole. Talvez se possa objetar a essa aproximação que há na estética futurista um impulso positivo de identificação com a atmosfera do "tecnológico mundo moderno", problematizado, contudo, a cada nova etapa do romance de Dos Passos. Em primeiro lugar, essa descrição é retirada daquele momento, já comentado, em que Ed Thatcher sonha com a sua promoção a sócio da firma para a qual trabalha. A descrição em chave esperançosa, portanto, é uma expressão do estado de espírito da personagem, e o tom positivo tanto da passagem quanto do devaneio de Ed será sufocado pelo movimento da forma e o andamento do enredo. Mortimer também destaca a objetificação das personagens, que se tornam "bonecos mecânicos", como ocorre no penúltimo trecho transcrito - dado que remeteria, mais uma vez, à estética do futurismo. Se pensarmos nos quadros mais conhecidos das duas primeiras décadas do século XX de Ferdinand Léger, uma referência da pintura futurista para Dos Passos, a rigidez e a ausência de dinamismo da objetificação de Ellen contradizem os elementos mais otimistas e confiantes na combinação que resulta do mundo subjetivo regido pela esfera da produção industrial. A apatia desses bonecos lívidos e amargurados parece se aproximar mais dos retratos de Kirchner ${ }^{264}$ ou dos corpos alienados dos indivíduos dos primeiros contos da fase expressionista de Alfred Döblin ${ }^{265}$. É possível conjecturar se Dos Passos chegou a conhecer esses artistas. Possivelmente não os conheceu diretamente, mas pode ter sido influenciado por certos aspectos do expressionismo durante a sua estadia na Europa e por meio da produção teatral da década de XX, com a qual trabalhou avidamente.

A peça The adding machine, de Elmer Rice, estreou em 1923 e "é considerada a obra-prima do expressionismo americano"266. Segundo Iná Camargo Costa, a

\footnotetext{
como um barco com rodas de pás subindo o Hudson sob as Palisades, como um desfile eleitoral, por ruas compridas em direção a uma coisa branca, alta, cheia de colunatas e imponente. Metrópole." [Tradução nossa]. DOS PASSOS, John. Manhattan Transfer, cit. p. 12.

264 "One recalls Kirchner's use of space to create tension and heighten expression." SPINDLER, Michael. John Dos Passos and The Visual Arts, cit., p. 394.

${ }^{265}$ Ver, por exemplo, os contos „Die Ermordung einer Butterblume” e "Die Tänzerin und der Leib”. DÖBLIN, Alfred. "Die Ermordung einer butterblume” und andere Erzählungen. Munique: Deutscher Taschenbuch Verlag, 1980.

${ }^{266}$ COSTA, Iná Camargo. Panorama do Rio Vermelho: ensaios sobre o teatro americano moderno. São Paulo: Nankin Editorial, 2001, p. 67. Embora Elmer Rice diga que não conhecia o drama expressionista até a produção da peça The Adding Machine, ele reconhece como pertinentes as aproximações feitas por críticos entre a sua peça e o teatro, por exemplo, de Georg Kaiser. Ver ELWOOD, William R. An
} 
influência do teatro expressionista é explícita, principalmente no diálogo direto com a peça de Georg Kaiser, De manhã à meia-noite. A montagem da obra de Rice teve uma grande repercussão na época e certamente era conhecida por Dos Passos, que teve a sua primeira peça, The garbage man (anteriormente intitulada The moon is a gong), encenada em 1926. A partir de 1925, Dos Passos se voltou com bastante expectativa para o teatro ao fundar, ao lado de Howard Lawson, Michael Gold, Francis Faragoh e Em Jo Basshe, o já mencionado New Playwrights Theatre. Pouco tempo depois, quando o grupo resolveu encerrar suas atividades, Dos Passos escreveu uma breve retrospectiva acerca da produção desses anos e, comentando uma peça de Upton Sinclair, Singing jailbirds, afirmou que a audiência nova-iorquina já estava habituada aos "métodos do expressionismo". Esses métodos, que Dos Passos acredita ter empregado em sua primeira peça, The garbage man ${ }^{267}$, também teriam influenciado, ainda segundo o autor, a trilogia U.S.A.. O estilo dessa obra monumental teria sido inspirado por seu 'entusiasmo pelo teatro 'expressionista' dos anos de 1920 "268. Embora nesse texto, escrito por ocasião da produção da versão teatral de U.S.A. (1959), Dos Passos vincule esses "métodos" e "estilos" especificamente à trilogia, podemos nos perguntar se Manhattan Transfer não sofreu também essa influência, já que foi publicado no mesmo ano em que a peça The garbage man foi encenada $^{269}$.

Não se buscará traçar todas as evidências de uma provável influência expressionista no romance de Dos Passos, pois não se trata de sugerir uma relação direta, principalmente porque o expressionismo, talvez ainda mais que outras vanguardas do início do século XX, conjuga uma série de manifestações díspares que,

Interview with Elmer Rice on Expressionism. Educational Theatre Journal, 20th-Century American Theatre Issue, v. 20, n. 1, p. 01-07, Mar. 1968.

${ }^{267}$ DOS PASSOS, John. Looking Back On U.S.A. (1959). John Dos Passos: The Major Nonfictional Prose. p. 235. "Em The Moon is a Gong (1925) ou em The Garbage Man (1926), que é título posterior, Dos Passos empregou o método expressionista". WRENN, John H. John Dos Passos. Rio de Janeiro: Editora Lidador, 1966. p. 132

${ }^{268}$ DOS PASSOS, John. Looking back on U.S.A (1959), cit., p. 119.Ver também VALGEMAE, Mardi. Expressionism in the American theater. In: WEISSTEIN, Ulrich (Ed.). Expressionism as an international literary phenomenon: twenty-one essays and a bibliography. Filadélfia: John Benjamins Publishing Company, 1973.

269 "During the winter of 1922-23 when he worked at it [Garbage Man] again, both his play and new novel, Manhattan Transfer, were close kin to one another in content and expressionistic method. (...) Some of the techniques Dos Passos had begun to experiment with in Manhattan Transfer were not unlike what he and Lawson were doing in their plays. For Dos Passos, both play and novel used the mosaic of New York City as its backdrop. Like the play, his new novel was developing amid a cacophony of sounds and rhythms." CARR, Virginia Spencer. Dos Passos. A life. Evanston: Northwestern University Press, 2004, p. 193-194. 
muitas vezes, possuem relações vagas entre si. Na composição de Manhattan Transfer, como tentamos mostrar, a relação da subjetividade com o tempo industrial e a modernização da metrópole exprime mais um desconcerto do que uma adesão otimista e revela também certa "distorção expressionista da realidade exterior" $270 \mathrm{em}$ uma cidade onde "coisas e objetos absorvem o humano",271.

26) Pour on water, Scotland's burning. Don't like the smell in this place in the City of New York, County of New York, State of New York. He lay on his back on the floor of the revolving kitchen and laughed and laughed. The only man who survived the flood rode a great lady on a white horse. Up in flames, up, up. Kerosene whispered a greasyfaced can in the corner of the kitchen. Pour on water. He stood swaying on the crackling upside down chairs on the upside down table. The kerosene licked him with a white cold tongue. He pitched, grabbed the gasjet, the gasjet gave way, he lay in a puddle on his back striking matches, wet wouldn't light. A match spluttered, lit; he held the flame carefully between his hands ${ }^{272}$.

A cena da morte de Stan é exemplar para discutir como os elementos ganham autonomia em relação às personagens e de que modo a descrição elabora uma distorção da realidade, explorando a autonomização dos objetos ${ }^{273}$. Esses procedimentos dialogam com o mesmo mecanismo no episódio em que Ellen vai aos poucos se alienando de si mesma, inicialmente imaginando-se como uma boneca ("she kept winding up a hypothetical dollsef and setting it in various positions. Tiny gestures ensued, acted out on various model stages"274); em seguida, sentindo-se tomada por uma onda de gelo e tornando-se uma "foto de si mesma" para, por fim, metamorfosear-se em uma figura rígida de porcelana, para a qual Baldwin passa a ser uma "marionete de madeira". Esses elementos talvez tornem mais clara a oposição que Dos Passos pretendia estabelecer em relação ao "subjetivismo" de Ulisses. Sobre esse tema, Raymond Williams comentou que a consciência, no romance de Joyce, é

\footnotetext{
${ }^{270}$ PIZER, Donald. Toward a modernist style: John Dos Passos. New York: Bloomsbury Academic, 2013, p. 2.095.

${ }^{271}$ PIZER, Donald. Toward a Modernist Style..., cit., p. 2.853.

272 “Joga água, a Escócia está pegando fogo. Não gosto do cheiro desse lugar na Cidade de Nova York, Condado de Nova York, Estado de Nova York. Ele deitou de barriga pra cima no chão da cozinha rodopiante e riu e riu. $\mathrm{O}$ único homem que sobreviveu à enchente cavalgava uma grande dama num cavalo branco. Em chamas, chamas. Querosene sussurrou uma lata de rostoleoso no canto da cozinha. Joga água. Ele ficou balançando nas cadeiras crepitantes de ponta cabeça na mesa de ponta cabeça. A querosene o lambeu com uma fria língua branca. Ele arremessou, agarrou o bico de gás, o bico de gás cedeu, ele ficou deitado em uma poça de barriga pra cima acendendo fósforos, molhado não vai acender. Um fósforo cuspiu, acendeu; ele segurou a chama cuidadosamente entre suas mãos". [Tradução nossa[. DOS PASSOS, John. Manhattan Transfer, cit., p. 214.

${ }^{273}$ Quando voltou a Manhattan em 1921, Dos Passos escreveu uma carta a sua amiga, Germaine LucasChampionère, descrevendo as suas considerações sobre a cidade e enfatiza a sua impressão sobre a relação entre as pessoas e os objetos: "People swarm meekly like ants (...) crushed by the disdainful and pitiless things around them". DOS PASSOS, John apud LUDINGTON, Townsend. John Dos Passos..., cit., p. 200.
}

${ }^{274}$ DOS PASSOS, John. Manhattan Transfer, cit., p. 317. 
"basicamente subjetiva - mas inclui, na própria forma de sua subjetividade, os outros que agora, juntamente com os prédios, os ruídos, as vistas e cheiros da cidade, fazem parte dessa consciência"275. Em Manhattan Transfer, a perspectiva é oposta; a subjetividade não inclui esse mundo de coisas, mas é tomada por ele.

Quando, quatro anos mais tarde, Alfred Döblin escreveu o seu romance Berlin Alexanderplatz, um dos efeitos da montagem era justamente o de contrastar a trama de um anti-heroí como Franz Biberkopf a fragmentos que demonstravam, em sua estrutura, ausência de relação e, no limite, falta de necessidade. Embora a sua trajetória esteja imersa nessa estrutura que exerce uma força de desagregação sobre a personagem, o leitor ainda assim o acompanha de perto. Todas as pequenas e enormes reviravoltas das quais Biberkopf é vítima, as transformações de sentimento e as etapas que propelem a personagem ao seu desenlace, são escancaradas pela narrativa. No caso do romance de Dos Passos, ao contrário, os hiatos são extensos e os momentos decisivos não chegam sequer a ser ocultados: parecem quase sem sentido. Mesmo as personagens mais recorrentes, como Ellen e Jimmy, não exigem o mesmo tipo de empatia do leitor que o gigante Biberkopf, "nosso bom homem", estabelece (para o bem e para o mal). Seria impossível dizer de Manhattan Transfer, como Benjamin o fez em relação a Berlin Alexanderplatz, que se trata do "estágio mais extremo, mais vertiginoso, mais definitivo, mais avançado do velho 'romance de formação' do período burguês" ${ }^{276}$. Se na trajetória de Biberkopf existe uma disputa entre a lógica social que o desagrega e a força desse empático marginal que exige da vida mais do que o pão com manteiga, em Dos Passos as personagens carecem desse espaço de desenvolvimento necessário à identificação. Nesse contexto, ressalte-se que o romance de Dos Passos foi muito criticado, desde a sua publicação, pela elaboração das personagens. "Fracas", "planas", "insensíveis", elas pareciam não atender às exigências do gênero do romance, não respeitar o mínimo de identificação que se almeja quando tomamos em mãos uma obra de ficção. As críticas estão corretas no diagnóstico. As personagens de Dos Passos são realmente planas. A única que talvez se diferencie em alguma medida é Ellen, mas, ainda assim, não o suficiente para "salvar" a obra. Ocorre que, na sátira de Dos Passos, não há possibilidade de aprofundamento individual porque às partes alienadas é vedada qualquer chance de desenvolvimento. Essa construção é o resultado necessário da forma do romance e,

${ }^{275}$ WILLIAMS, Raymond. O campo e a cidade. p. 400.
${ }^{276}$ BENJAMIN, Walter. A crise do romance. cit., p. 60. 
mais do que isso, do desenvolvimento específico da urbanização experimentada em Nova York.

A força de Manhattan Transfer reside no fato de que a montagem realiza, formalmente, o tema da impossibilidade de individuação, da alienação progressiva desses sonâmbulos e a quase "mineralização dos resíduos de experiência" "277 (por exemplo, a experiência de coisificação de Ellen no fim do romance). Incorporada à economia da obra, a ruptura, como procedimento sistemático da montagem, recusa a totalidade orgânica do realismo formal. Essa estrutura fragmentária rejeita a exclusividade das relações de causa e efeito, organizadoras da trama progressiva. Não são mais o ato do indivíduo nem as suas motivações emocionais que determinam a dinâmica da representação.

Como sonâmbulas, essas personagens percorrem um trajeto repleto de hiatos: o tempo de suas vidas é feito de ausências. A construção espacial operada pelo princípio estilístico do romance, contudo, é um "mosaico de pequenos mundos, que se tocam sem se interpenetrar" ${ }^{278}$ e que ganham força e dinâmica por meio da estrutura da montagem.

\footnotetext{
${ }^{277}$ Quem encontrou essa expressão tão adequada para o fenômeno foi o professor Marcos Soares em uma aula sobre o romance de Dos Passos em 2015.

${ }^{278}$ PARK, Robert. Human behavior in Urban Environment. In: BURGESS, Ernest W.; MCKENZIE, Jean-Pierre; PARK, Robert; DUNCAN, Roderick. The City, Chicago: The University of Chicago Press, 1967. p. 40.
} 


\title{
4. DA CARROÇA AO METRÔ: \\ A PREPONDERÂNCIA DO ESPAÇO
}

\author{
this greatest of machines, a great city, \\ rises to proclaim the marvel of the units \\ of its structure \\ The art and craft of the machine (1901), \\ Frank Lloyd Wright
}

\subsection{Cartografias: Ellen}

Quando o leitor se depara com a personagem de Ellen, logo nas primeiras páginas do romance, percebe que não existem coordenadas geográficas específicas. Sabe-se que estamos em uma maternidade, percorremos os rostos cansados das mães em seus leitos até conhecer Susie e, finalmente, a recém-nascida primogênita do casal. Por sua constância em uma obra tão cheia de rupturas e abandonos, a personagem foi considerada por alguns críticos a protagonista do romance ${ }^{279}$, um argumento que pode ser reforçado, entre outros aspectos, pelo fato de que a sua presença se constrói desde o seu nascimento:

27) The nurse brought back a basket and set it on the bed beside Susie.

"Oh isn't she wonderful!" said Ed. "Look she's breathing... And they've oiled her." He helped his wife to raise herself on her elbow; the yellow coil of her hair unrolled, fell over his hand and arm. "How can you tell them apart nurse?"

"Sometimes we cant," said the nurse, stretching her mouth in a smile. Susie was looking querulously into the minute purple face. "You're sure this is mine."

"Of course."

"But it hasnt any label on it."

"I'll label it right away."

"But mine was dark." Susie lay back on the pillow, gasping for breath.

"She has lovely little light fuzz just the color of your hair."

Susie stretched her arms out above her head and shrieked: "It's not mine. It's not mine. Take it away... That woman's stolen my baby"280.

\footnotetext{
${ }^{279}$ CASEY, Janet Galligani. Dos Passos and the ideology of the feminine. Cambridge: Cambridge University Press, 1998, p. 106; WAGNER, Linda. Dos Passos..., cit., p. 52.

280 “A enfermeira trouxe o cesto e colocou na cama ao lado da Susie. 'Ai, ela não é linda!' disse Ed. 'Olha, ela tá respirando... E eles passaram óleo nela.' Ele ajudou sua esposa a se levantar apoiando seu cotovelo; a trança amarela do seu cabelo se soltou, caiu sobre suas mãos e braços. 'Como você consegue distinguir uns dos outros, enfermeira?' 'Às vezes não consigo', disse a enfermeira, esticando a boca em um sorriso. Susie olhava irritada para o pequeno rosto roxo. 'Tem certeza de que ela é minha?' 'Claro que sim'. 'Mas está sem nenhuma etiqueta'. 'Eu vou resolver isso agora mesmo'. 'Mas a minha era escura'. Susie deitou sobre o travesseiro, ofegante. 'Ela tem um cabelinho lindo da mesma cor do seu'. Susie esticou os braços na altura da cabeça e berrou: 'Não é minha. Não é minha. Leva daqui... Essa mulher roubou meu bebê.'” [Tradução nossa.] DOS PASSOS, John. Manhattan Transfer, cit., p. 6.
} 
A cena é breve e despretensiosa em sua construção, atendo-se a um incidente cotidiano. Os acontecimentos que nela transcorrem podem ser justificados por um possível estresse decorrente do parto e por uma tendência sensível da própria Susie, mencionada por Ed Thatcher assim que este chega ao hospital: “you see, it's out first and Susie' so delicate"281. Todavia, o episódio alude, de forma anedótica, a alguns dos principais temas da obra e que surtirão efeito na trajetória de Ellen, a saber, o fenômeno de aglomeração e a sensação difundida de impossibilidade de individuação ou, antes, da realização das promessa de individuação. Se Bud chega à cidade com a expectativa de conseguir apagar-se em meio à multidão ("uma agulha num palheiro"), Ellen, uma das poucas personagens nascidas em Nova York, já carrega consigo a marca desse espaço e do tipo de experiência que vimos se desdobrar em todo o romance.

Essa experiência é expressa, socialmente, na impossibilidade de um desenvolvimento livre da individualidade (que, na estrutura do romance, exprime-se na interrupção brusca e nas lacunas de cada trama, na ausência de encadeamento, progressão e acúmulo), na relação tênue entre as personagens, nos encontros fortuitos e inconsequentes. O padrão de relações gerado pela organização narrativa impõe uma lógica ao espaço, ao tempo e à vida, que é a lógica da circulação de mercadorias, da substituição, da equivalência. Se essa experiência marca o nascimento de Ellen - mais um bebê entre tantos outros nessa fábrica de nascimentos -, ela também desdobra-se nos fragmentos de sua vida de diversas formas, sendo uma delas a constante tentativa de apagamento do passado.

Ao apontar, em Mrs. Dalloway, a persistência do passado, o crítico Robert Alter enfatiza o modo como a estrutura da narrativa, o tipo de construção sintática e de modos de representação são responsáveis por estabelecer uma conexão entre o tempo presente e a história transcorrida, os eventos atuais e a memória ${ }^{282}$. A história de Ellen, reiterado apagamento de sua trajetória pessoal (até o momento em que se cristaliza na mítica Helena, como vimos no capítulo anterior), está relacionada à dinâmica da cidade, explicitada pela construção literária, que impede que cada uma das personagens se aproprie do papel de protagonista. A relação entre a dinâmica desse espaço urbano em crescimento e a subjetividade foi expressa em Manhattan

\footnotetext{
${ }^{281}$ DOS PASSOS, John. Manhattan Transfer, cit., p. 5.

${ }^{282}$ ALTER, Robert. Imagined cities. Urban experience and the language of the novel. New Haven; London: Yale University Press, 2005, p. 105.
} 
Transfer como algo novo, muito específico das condições em que de davam as transformações dessa metrópole. Há um breve trecho no ensaio de George Simmel, publicado em 1903, “A Grande Cidade e a Vida do espírito”, que pode nos indicar algumas pistas acerca dessa dinâmica:

\begin{abstract}
Weimar não é nenhum contraexemplo, pois sua significação estava ligada a personalidades singulares e morreu com elas, enquanto a cidade grande se caracteriza precisamente em virtude de sua independência essencial, mesmo com relação às personalidades singulares mais significativas - a contrapartida e o preço da independência que o singular desfruta em seu interior. A essência mais significativa da cidade grande repousa nessa grandeza funcional, para além de seus limites físicos ${ }^{283}$.
\end{abstract}

$\mathrm{O}$ romance de Dos Passos não dedica atenção alguma às "grandes personalidades" de sua época ou da história - o que é decisivo. Os grandes nomes da história dos Estados Unidos, e mesmo possíveis figuras de destaque da virada do século, já estão, a princípio, fora do escopo de representação de Manhattan Transfer (ao contrário, por exemplo, do papel fundamental exercido pelas biografias de grandes personalidades na trilogia U.S.A.). A "independência essencial” da metrópole articula-se nesse romance de 1925 ao fato de que, por um lado, nenhuma das tramas pode subsumir a totalidade da obra. Seria difícil sintetizar o enredo dizendo tratar-se da vida de uma jovem atriz que, em meio a desventuras amorosas, acaba casando-se por conveniência e tornando-se uma grande editora de moda. Tampouco poderíamos alegar que se resume à narrativa de um jovem órfão que, abandonando a chance de sucesso comercial oferecida pelo tio, coleciona fracassos na carreira e na vida afetiva. $\mathrm{O}$ núcleo da matéria do romance não pode ser resumido à trajetória biográfica de Ellen, pois também Anna, Bud, Stan impregnam o texto com os cacos de seus percursos, violentos e breves. E é esse enredamento necessário e quase obsessivo de fragmentos que a narrativa pretende produzir ao suprimir, das unidades narrativas mais fortes (Ellen e Jimmy), a narração ou apresentação de acontecimentos impactantes - como a morte da mãe de Jimmy.

Do ponto de vista da estratégia narrativa, portanto, é importante que as histórias dessas personagens mais recorrentes contenha muitas rupturas e omissões. Se, no caso de Ellen, a morte da mãe, o casamento com Jojo e a descoberta do suicídio de Stan - grandes eventos traumáticos - não aparecem representados

\footnotetext{
${ }^{283}$ SIMMEL, Georg. As grandes cidades e a vida do espírito (1903). Mana, Rio de Janeiro, v. 11, n. 2, p. 586, Oct. 2005. Disponível em: $<$ http://www.scielo.br/scielo.php?script=sci_arttext\&pid=S010493132005000200010\&lng=en\&nrm=iso >. Acesso em: $1^{\circ}$ set. 2016.
} 
narrativamente, a possibilidade de sua trama se tornar um suposto ponto de convergência de todos os outros elementos do romance (por exemplo, como ocorre com o casal March, em A harzard of new fortunes) se enfraquece. Isso também pode ser dito sobre a trajetória de Jimmy. Não é à toa que apenas no caso daquelas narrativas mais curtas e fragmentadas (Bud, Stan, Anna) sejam representados acontecimentos decisivos: o ambíguo suicídio de Bud e Stan, o acidente trágico de Anna. Esses eventos podem aparecer porque essas personagens, pelo pouco espaço que tomam na narrativa, não poderiam expandir-se em importância e correr o risco de se tornarem o ponto focal do romance. Cada uma dessas três personagens aparece em apenas uma seção do romance (na primeira, segunda e terceira, respectivamente), enquanto os episódios das vidas de Ellen e Jimmy pontuam, de forma intermitente, a obra toda. Por meio dessa articulação dos enredos, Dos Passos consegue cumprir o seu projeto de criar uma espécie de "crônica simultânea" (como o próprio autor gostava de dizer) cujo resultado não poderia ser subsumido a uma vida particular, ao "modelo da memória autobiográfica" ${ }^{284}$. Em um romance em que a própria memória é colocada em questão, a "subordinação" das partes a um enredo particular é problematizada pela representação do tempo simultâneo e pela aglomeração, no espaço do romance, das vidas e histórias.

É essa estrutura que garante o que Simmel chamou de "independência essencial" da metrópole. As ressonâncias entre o romance e o texto de Simmel (escrito na mesma época em que se passa Manhattan Transfer) ocorrem porque o ensaio pretende não apenas indicar os processos e os dados materiais que determinam o que seria uma metrópole, mas, sobretudo, refletir sobre o efeito desse tipo de socialização na constituição do indivíduo, ou seja, sobre a "vida do espírito". De forma pouco ou nada sistemática, Simmel não discute categorias políticas e econômicas que delimitariam o que se compreende por uma cidade moderna no mundo ocidental - no ensaio de Simmel, isso está dado como pressuposto. Parte-se da ideia de uma espécie de organização urbana que passou por um estágio de desenvolvimento técnico para abordar, a partir daí, quais os impactos dessa "estrutura social" na esfera individual, quais "ajustes" e "adaptações" o indivíduo deve realizar para enfrentar as "potências que lhe são exteriores"285. A influência desse ensaio nas reflexões posteriores sobre a metrópole é significativa (por exemplo, para Robert E.

\footnotetext{
${ }^{284}$ WATT, Ian. A ascensão do romance, cit., p. 16.

${ }^{285}$ SIMMEL, Georg. As grandes cidades e a vida do espírito (1903), cit., p. 577.
} 
Park), e as discussões sobre ele são inúmeras. Portanto, um comentário curto sobre o texto poderia correr o risco de não fazer jus ao caráter aberto desse ensaio, repleto de “tensões não resolvidas”"286. Para a presente análise, contudo, vale destacar ainda mais um ponto: a sugestão de Simmel de que o espaço da grande cidade propicia uma liberdade em relação a certas restrições morais das pequenas vilas - com contrapartidas, é claro. No romance de Dos Passos, essa característica aparece na liberdade sexual de Ellen, cujo caso com Stan, anterior a seu divórcio, permanece relativamente privado; ou no exemplo de Anna, com seus diferentes namorados, participações em greves e trabalho como costureira. Ou, ainda, no caso da prima de Jimmy, Maise Merivale, noiva de um homem já casado. Essa liberdade e esse anonimato são constitutivos das tramas do romance: as personagens se cruzam, mas não se conhecem e podem manter um nível grande de privacidade. Também o leitor cruza com elas como se ele mesmo fosse mais uma personagem dobrando as esquinas, olhando de relance pessoas que saem dos prédios, captando pequenos fragmentos de histórias, conversas, acidentes.

Ainda segundo Simmel, uma das contrapartidas dessa liberdade gerada pela dimensão da metrópole e pela convivência entre desconhecidos reside na "intensificação da vida nervosa", devido ao acúmulo veloz de percepções variadas e à simultaneidade de estímulos, resultando naquilo que o autor descreve como um "fenômeno peculiar de adaptação": a postura blasé do indivíduo nos grandes centros metropolitanos. Quase uma nova "competência", trata-se de uma maneira de "gerenciar" os sentidos e a hiperestimulação. Para Simmel, essa postura representa uma forma de proteção frente a uma nova situação desencadeada por uma confluência de fatores, como o aumento exponencial da densidade populacional e o desenvolvimento de novas técnicas que alteram todas as formas de relações sociais, homogeneizando-as ${ }^{287}$.

A tensão entre essa liberdade proporcionada pelo anonimato e os efeitos do tempo e da densidade da metrópole sobre a sensibilidade do sujeito se expressa de

\footnotetext{
${ }^{286}$ FRISBY, David. Simmel et le paysage urbain de la modernité. In: FÜZESSÉRY, Stéphane; SIMAY, Philippe (Org.). Le choc de métropole: Simmel, Kracauer, Benjamin. Paris: Éclat, 2008, p. 100.

287 “A cidade grande moderna, contudo, alimenta-se quase que completamente da produção para o mercado, isto é, para fregueses completamente desconhecidos, que nunca se encontrarão cara a cara com os verdadeiros produtores. Com isso, o interesse das duas partes ganha uma objetividade impiedosa, seus egoísmos econômicos, que calculam com o entendimento, não têm a temer nenhuma dispersão devida aos imponderáveis das relações pessoais." SIMMEL, Georg. As grandes cidades e a vida do espírito (1903), cit., p. 579.
} 
maneira singular nas trajetórias de Ellen pela cidade. Ela aparece constantemente cortando a cidade de norte a sul e atravessando parques - espaços onde há uma contraposição entre a personagem que se desloca e pessoas que, paradas, estão em condição de observá-la. Para Ellen, a relação com a cidade e com essas outras pessoas é predominantemente predatória. Desde a cena da sua infância, em que, voltando da escola e atravessando o Central Park, sente a presença de um sequestrador ${ }^{288}$, passando pela conversa com seu pai em Battery Park, em que ela questiona o fato de não poder conversar com estranhos na rua por ser menina ${ }^{289}$, a relação de Ellen com o espaço é repleta de ansiedade e inquietação. Mesmo na cena em que atravessa a cidade do Harlem até o sul da ilha, em que o tom é quase de euforia, a personagem se desloca "tateando por um emaranhado de barulhos arenosos, afiados e quebradiços" 290 . Os efeitos da cidade sobre ela chegam a ser físicos e, na maioria das vezes, sugerem atrito e agressão. Quando entra em um restaurante no Central Park com seu agente, Harry Goldweiser, todo o ambiente à sua volta parece ameaçador: "A hot gust of foodsmell and the rhythm of a band playing He's a Ragpicker swirls chokingly about her" ${ }^{291}$. Chokingly é mais do que suffocating, pois a palavra remete de forma mais direta à ideia de enforcamento do que de sufocamento decorrente, por exemplo, de uma atmosfera carregada por odores. Ao utilizar a expressão chokingly, a narrativa reforça a sensação como algo corporal, dinâmico, quase um ataque.

Esse tipo de relação entre o espaço, a aglomeração e a personagem é específico dos fragmentos de Ellen. Embora Jimmy também vivencie uma sensação tangível de perseguição durante a infância, quando sai de casa para ir à confeitaria, isso não se prolonga durante a sua fase adulta. A tensão vivenciada por Ellen é peculiar da personagem e, poderíamos ainda ir mais longe, de uma mulher na cidade. Principalmente em uma cidade cuja dinâmica rígida parece refratária à permeabilidade da memória e à absorção das marcas deixadas pelas vidas individuais que a percorrem.

\footnotetext{
${ }^{288}$ DOS PASSOS, John. Manhattan Transfer, cit., p. 46.

${ }^{289}$ DOS PASSOS, John. Manhattan Transfer, cit., p. 52. (Trecho 13, transcrito e comentado na página 93 desta tese.)

${ }^{290}$ DOS PASSOS, John. Manhattan Transfer, cit., p. 115.

291 "Um bafo quente de cheirodecomida e o ritmo de uma banda tocando He s a Ragpicker rodopiam asfixiantes à sua volta”. DOS PASSOS, John. Manhattan Transfer, cit., p. 172.
} 


\subsection{Cartografias: Bud, Jimmy e os limites da metrópole}

$\mathrm{Na}$ trama de Bud temos, desde o princípio, coordenadas definidas. Ao desembarcar em Manhattan, ele encontra imediatamente a avenida que vai costurar muitos de seus percursos, a Broadway. Decidido a procurar "o centro das coisas", os seus primeiros passos são titubeantes, mas esperançosos, convictos. Em alguma medida, a cidade parece cumprir o que lhe prometera: fazer dele um anônimo, apagar a sua história, "nada além de uma agulha no palheiro". Percorrendo a ilha atrás de trabalho durante alguns meses, Bud avança pelos espaços degradados da metrópole: os terrenos baldios, espaços em construção, as ruínas sempre provisórias de uma cidade que cresce em ritmo alucinante.

Bud, como muitas das personagens do romance, vem "de fora". O seu percurso até a ilha é árduo - uma caminhada de muitos quilômetros, com o sol escaldante sobre a cabeça e a barriga vazia que arrasta consigo. Vir "de fora" supõe a contraposição entre dois espaços: o espaço da memória, que ele carrega da vida que deixou, e o espaço concreto da vivência cotidiana. Já vimos, contudo, que raramente é despertada a memória das personagens e que, quando aparecem em fragmentos, as suas histórias são repletas de interrupções e dificilmente recuperadas no decorrer da narrativa. No caso de Bud, a sua história aparece emaranhada primeiro em um devaneio $^{292}$; depois, é reformulada e vagamente explicada no diálogo com o seu companheiro de albergue. É pelo relato e pela memória involuntária (quando Bud devaneia na cadeira do barbeiro) que se configura uma das poucas imagens da vida no campo. O mundo natural da experiência campestre poderia surgir, como ocorre frequentemente em certa tradição romanesca, em oposição à ordem mecânica da cidade, representando um espaço onde se restitui a ordem orgânica negada no mundo urbano - oposição que representa um topos antigo na literatura. O crítico Michael Clark, em Dos Passos's early fiction, aproxima Dos Passos de Walt Whitman baseando-se, principalmente, no tipo de relação com a natureza desenvolvida na obra de ambos:

Whitman's rude pragmatism probably appealed to Dos Passos, but as this study proceeds, it will become increasingly apparent that Whitman's legacy to Dos Passos was indeed an appreciation of man's relationship to nature. It should not be surprising that such a theme should figure in Dos Passos's understanding of and enthusiasm for Whitman's poetry, for the received opinion by the time of Dos

${ }^{292}$ A cena da barbearia, em que Bud, entre o sono e a vigília, revê imagens da morte de seu pai. 
Passos's undergraduate years was that Whitman was first and foremost a spokesman for nature ${ }^{293}$.

Para Clark, o romance alerta o leitor para a desarmonia que se expressa entre as personagens urbanas e a natureza, sugerindo que o retorno a um estado orgânico ainda seria possível. Que o crítico faça uma tal leitura da oposição entre campo e cidade no romance é significativo e merece atenção, porque impacta a sua interpretação sobre a fuga final de Jimmy e, em última análise, sobre o significado da cidade. Para alguns críticos, a fuga de Jimmy no final do romance representaria uma rejeição completa da lógica que organiza a metrópole e revelaria uma abertura a novas possibilidades condensada na imagem de um retorno à vida campestre. O próprio Michael Clark sustenta que, fugindo da "sordidez de Nova York", no final Jimmy está a caminho de recuperar uma "harmonia natural"294. Alguns indícios presentes nos últimos parágrafos da conclusão do romance parecem corroborar essa interpretação: em seu artigo "La Ciudad Enferma", Rebeca Gualberto Valverde sustenta que a fuga de Jimmy seria uma forma de se opor à lógica da cidade, e o grande símbolo dessa reconquista do espaço rural seria a carroça cheia de flores ao seu lado na balsa em que ele atravessa o rio para buscar outras paragens. A carroça e as flores representariam, segundo a autora, uma oposição às flores apagadas do tapete da casa dos Thatcher $^{295}$ ou às flores moribundas que Ellen rejeita durante o seu jantar com Baldwin ${ }^{296}$. Após enfatizar que Ellen "siente atracción por las flores artificiales, flores que nacen y viven muertas para siempre (...) porque Ellen siente aversión por la vida" ${ }^{297}$, Gualberto Valverde argumenta que as flores que Jimmy observa quando está com Ellen em seu idílio durante a guerra na Europa (ou, melhor, quando reconstitui esse idílio pela recordação) constituem "el opuesto simbólico de las flores artificiales y, por tanto, da cuenta de un espacio alternativo a la ciudad donde las flores silvestres sí pueden crecer" $^{298}$. O final, portanto, seria carregado pela simbologia da vida, em

\footnotetext{
${ }^{293}$ CLARK, Michael. Dos Passos's early fiction, cit., p. 23.

${ }^{294}$ CLARK, Michael. Dos Passos's early fiction, cit., p. 103.

295 "Ellen dropped onto the davenport and let her eyes wander among the faded red roses of the carpet." DOS PASSOS, John. Manhattan Transfer, cit., p. 168.

296 "A shower of faded petals fluteres onto her hand, her gloves, the table. She shook them off her hands. "And do have him take these wretched roses away George... I hate faded flowers"'. DOS PASSOS, John. Manhattan Transfer. p.186

${ }^{297}$ GUALBERTO VALVERDE, Rebeca. La ciudad enferma: espacio, metáfora y mito en Manhattan Transfer, de John Dos Passos. Ángulo Recto, Revista de estudios sobre la ciudad como espacio plural, v. 3, n. 1, p. 186, 2011. Disponível em: <http://www.ucm.es/info/angulo/volumen/Volumen031/varia05.htm>. Acesso em: 02 jan. 2017.

${ }^{298}$ GUALBERTO VALVERDE, Rebeca. La ciudad enferma..., cit., p. 186-187.
} 
oposição à "cidade da morte" marcada pelas referências às "flores pintadas, cosidas o tapizadas":

En Manhattan Transfer, el ciclo vital de la naturaleza, esto es, la regeneración primaveral de la Tierra Baldía, se ve truncado. Al término de la novela Jimmy abandona la ciudad junto con un camión cargado de flores vivas. (...) La primavera - las flores que crecen en "la tierra de mayo"- debe mudarse fuera de la ciudad para poder sobrevivir ${ }^{299}$.

Sem dúvida, é tentador procurar na narrativa sugestões dessa dicotomia tão persistente na tradição do romance ocidental. Comentando a obra de Balzac - da qual é difícil fugir quando se trata da representação literária do desenvolvimento de uma grande metrópole -, David Harvey menciona a persistência de "cenas pastoris idílicas" e cita o crítico Fredric Jameson, para quem o campo em Balzac representaria "uma paz libertadora" frente a esse "crescimento rápido e aparentemente caótico de Paris" ${ }^{300}$. A importância da presença dessa dicotomia reside no fato de que a perspectiva propiciada pelo campo enforma o ponto de vista que irá "observar e interpretar" as estruturas sociais no universo urbano.

Gualberto Valverde aposta nessa dicotomia e na perspectiva redentora do campo, que seria realizada plenamente ao fim do romance. Há, contudo, certo excesso em sua análise: flores vivas e cheiros de flores reaparecem constantemente durante o romance $^{301}$, em diferentes situações. Quando, à mesa de jantar com Baldwin, Ellen repudia as flores mortas, seu gesto parece indicar acima de tudo repulsa diante da morte, e não uma suposta aversão "à vida"302 . Na verdade, não há qualquer indício no romance de que o campo possa se configurar como alternativa viável, instaurando um polo a partir do qual seja possível, "de fora”, observar a realidade; pelo contrário, o campo é repetidamente um espaço negado. Quando a vida rural aparece como matéria da memória de Bud, a imagem literária desautoriza compreendê-la como oposição, suposto espaço idílico onde a inocência revelaria, por contraste, as mazelas da vida na metrópole. Na memória e na reconstituição, o campo aparece como lugar de ignorância, da violência vinculada ao trabalho árduo e físico, não a um trabalho

\footnotetext{
${ }^{299}$ GUALBERTO VALVERDE, Rebeca. La ciudad enferma..., cit., p. 191.

${ }^{300}$ HARVEY, David. Os mitos da modernidade: a Paris de Balzac. In: modernidade. São Paulo: Boitempo, 2015, p. 45.

301 "He stopped in front of a flowerstore. A moist warm honied expensive smell came from the door, densely out into the keen steelblue street.” DOS PASSOS, John. Manhattan Transfer, cit., p. 238.

${ }^{302}$ Ademais, não deixa de ser curioso que a autora não comente a ironia presente na suposição de que o espaço idílico e orgânico campestre sonhado por Jimmy, antagônico à cidade, concretize-se justamente em meio à guerra.
} 
edificante, e ausência de lei. Trata-se de um espaço regido pela força e pelo trabalho pesado, em que a terra aparece misturada ao sangue.

O campo também aparece na fala do companheiro de albergue de Bud, quando revela que, nos dez anos em que mendiga pelas ruas de Nova York, o sonho de retornar à vida na fazenda nunca desapareceu - mas também nunca se concretizou. Em vez de surgir como refúgio, o campo se materializa como impossibilidade. Que força segura essas pessoas que não possuem qualquer laço ou garantia na cidade e, portanto, nada teriam a perder ao abandoná-la? No romance de Dreiser, para explicitar a força atrativa da grande metrópole, o narrador precisa anunciar que "ela [Carrie] era,

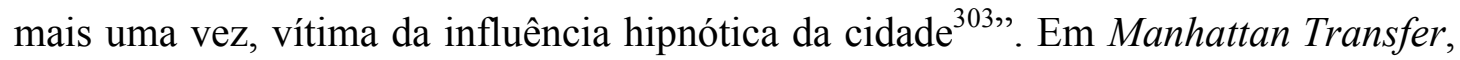
a própria forma do romance exerce esse poder.

A força em movimento no romance é totalizadora, e isso se revela no fato de que qualquer evento que se desenrole fora dos limites geográficos da cidade ser sistematicamente excluído da representação narrativa. O grande exemplo é a Primeira Guerra Mundial, evento, digamos, decisivo do período histórico que compreende a narrativa. É fato que, durante os primeiros anos da guerra, quando os Estados Unidos mantiveram ainda neutralidade no conflito, os efeitos das batalhas e das instabilidades, tão intensos nos países europeus, não eram sentidos de forma palpável no cotidiano das cidades estadunidenses. Apesar do medo iminente de que houvesse uma grande crise econômica ${ }^{304}$, no ano de 1914 (ou seja, em toda a segunda parte do romance), a guerra figura na narrativa apenas como "litografias num livro escolar, generais fazendo proclamações, minúsculas figuras correndo através de campos com os braços estendidos, fac-símiles de assinaturas" ${ }^{305}$. Nesse primeiro ano, portanto, ela parece como um rumor, histórias, inquietações, mas não mais que isso. Ocorre, contudo, que Ellen e Jimmy partem, juntos, para a frente de batalha na Europa. Nesse período, o romance os abandona - nós os vemos novamente apenas quando retornam. Fora da metrópole não há sequer possibilidade de narrativa.

Portanto, se Jimmy abandona Manhattan ao fim do romance, essa não é a primeira vez. Durante a Primeira Guerra, da qual temos apenas a reconstituição pela memória, a estadia na Europa parece um devaneio, e o retorno, o cumprimento

\footnotetext{
${ }^{303}$ DREISER, Theodor. Sister Carrie, cit., p. 85.

${ }^{304} \mathrm{O}$ tema da bolsa de valores e do impacto econômico reaparece algumas vezes no quinto capítulo da segunda parte: "The Street'll go plumb to hell... They'll lose the Stock Exchange". DOS PASSOS, John. Manhattan Transfer, cit., p. 184.

${ }^{305}$ DOS PASSOS, John. Manhattan Transfer, cit., p. 184.
} 
fatídico de seu quinhão. A partida derradeira de Jimmy se conclui, portanto, com um traço ambíguo: o homem que dirige a carroça com as flores está dormindo e cansado. É um trabalhador. Jimmy ensaia perguntar-lhe para onde vão as flores, mas desiste. Caminhando pela paisagem nebulosa de Nova Jersey, depara-se com um "cemitério" de produtos da industrialização: "The sun shines redly through the mist on rusty donkeyengines, skeleton trucks, wishbones of Fords, shapeless masses of corroding metal $^{306}$ ". No terreno áspero e sem horizonte, como uma reencenação da chegada de Bud à cidade, Jimmy caminha com bolhas nos pés ${ }^{307}$ e gasta o pouco que tem em um café da manhã. As semelhanças entre a sua caminhada e a de Bud deixam uma atmosfera pesada, que o romance não resolve. Além disso, Jimmy nem sequer é capaz de imaginar para onde ir, tamanha a força de dominação do espaço que vai se apagando atrás dele. Para D. H. Lawrence, na "feiura medonha de Nova Jersey", Jimmy está fugindo para "chegar ao nada"308.

Essa força totalizante da metrópole, que concentra a narrativa sempre dentro de seus limites geográficos, também se manifesta por meio da ausência de passado. Por um lado, a narrativa confere pouca importância a fatos pregressos, ao percurso biográfico da maioria das personagens. No caso de Bud, a sua história emerge como uma ferida e o tempo já transcorrido se faz presente, porque a sua biografia não se desenvolve. Pela fome e miséria, Bud habita ainda seu passado projetado no delírio de ser constantemente perseguido por investigadores da polícia. Há uma correlação entre essa personagem que o leitor acompanha por tão poucos meses e Jimmy, que vemos chegar ainda criança em Nova York: a imobilidade de Jimmy faz com que o seu passado se desintegre. Em ambos, parece que vemos essa impossibilidade de futuro observada por George Astre, para quem o tempo no romance é:

Um tempo horripilante, que não senão uma justaposição absurda de instantes tirânicos, um tempo heterogêneo o bastante para suprimir todo sentimento de futuro, qualquer projeto, é imposto pelo movimento febril das ruas ${ }^{309}$.

\footnotetext{
306 "O sol brilha avermelhado por entre a névoa sobre guinchosavapor enferrujados, esqueletos de caminhonetes, fúrculas de Fords, massas amorfas de metal corroído". [Tradução nossa] DOS PASSOS, John. Manhattan Transfer, cit., p. 342.

307 "With a long slow stride, limping a little from his blistered feet, Bud walked down Broadway, past empty lots." e "Jimmy walks fast [...]. He is hungry; his shoes are beginning to raise blisters on his big toes". DOS PASSOS, John. Manhattan Transfer, cit., p. 21 e 342, respectivamente.

${ }^{308}$ LAWRENCE, D. H. Review (1927), cit., p. 77.

${ }^{309}$ Tradução nossa do original: "Un temps cauchemaresque, qui n'est qu'absurde juxtaposition d'instants tyranniques, un temps assez hétérogène pour supprimer tout sentiment de devenir, tout projet, est imposé par le mouvement fébrile des rues". ASTRE, Georges-Albert. Thèmes et structures dans l'ouvre de John Dos Passos, cit., p. 141.
} 
Portanto, um dos aspectos fundamentais nesse romance é aparentemente não haver uma perspectiva externa, nem na forma de um espaço dicotômico, nem na forma da memória de um tempo anterior, pleno e orgânico. No meio do romance, no quinto capítulo da segunda parte, George Baldwin reflete sobre a sensação de que Nova York exerce um tipo de força centrípeta e que a sua vida é "go round and round in a squirrel cage ${ }^{, 310}$. Baldwin, Jimmy e Bud parecem rodar presos nesse presente tirânico, assim como Ellen aparece, ao fim, congelada em uma fotografia de si mesma.

\subsection{Cartografias: Manhattan}

Totalizadora, a metrópole não permite que se configure qualquer representação de uma experiência que ocorra além de seus limites geográficos. Exige que todos os fragmentos dispersos remetam sempre ao espaço que os contém. Todavia, esses pedaços desconjuntados não concorrem para formar uma totalidade de sentido. Em outras palavras, eles não conseguem organizar-se de forma a realizar um nexo de sentido em que todas as partes esclareçam laços e significados ocultos. Pelo contrário, as insuficiências das tramas são constitutivas dessa metrópole e não podem ser resolvidas pela imposição de uma unidade de experiência subjetiva. Daí decorre, por um lado, a multiplicidade de tramas e histórias. Por outro, a afirmação recorrente na crítica de que personagens, como Bud, Ellen ou Jimmy, que carecem de "importância e vitalidade"311, não poderiam assumir centralidade no romance e que a verdadeira protagonista apareceria sugerida no título, ou seja, trata-se da própria cidade. Mas o que garante que os protagonistas não são, de fato, Jimmy e Ellen, cujas trajetórias acompanhamos desde a infância? Ou, ainda, Bud, cuja história provavelmente é uma das que causam impressão mais profunda nos leitores?

\footnotetext{
${ }^{310}$ DOS PASSOS, John. Manhattan Transfer, cit., p. 187. Segundo William Dow, a metáfora seria um empréstimo da poesia de Blaise Cendrars, que Dos Passos tanto admirava e traduziu: "Dos Passos's borrowings from Cendrars of image as show, an evermoving exhibition, include the squirrel cage metaphor in Panama. Dos Passos cites in 'Homer of the Trans-Siberian' the individual self-torture of 'what Blaise Cendrars calls the squirrel cage of the meridians' (157-58). In Panama he translated Cendrars's 'Je tourne dans la cage des meridiens comme un ecureuil dans la sienna' as 'I go round and round inside the meridians like a squirrel in a squirrelcage"'. DOW, William. John Dos Passos, Blaise Cendrars, and the "Other" Modernism. Twentieth Century Literature, v. 42, n. 3, p. 407, Autumn 1996. Disponível em: <http://www.jstor.org/stable/441770>. Acesso em: $1^{\circ}$ ago. 2015.

${ }^{311}$ GELFANT, Blanche. The American city novel. Norman: University of Oklahoma Press, 1970, p. 14.
} 
A preponderância do espaço, que cresce com a repetição e o acúmulo de referências, já está anunciada no título, que alude não a um indivíduo, um possível protagonista, mas a um espaço determinado. Além de nomear, portanto, um espaço geográfico definido, o título faz referência a um momento histórico específico; afinal, a estação de trem "Manhattan Transfer", construída em 1910, indicava um momento importante da modernização da metrópole.

Winesburg, Ohio (1919), de Sherwood Anderson, Main street, (1920) de Sinclair Lewis são títulos similares, no que se refere ao destaque dado ao elemento espacial, ao de Dos Passos, embora em ambos os casos o foco de atenção seja, de certa forma, oposto ao de Manhattan Transfer. Essas duas obras importantes da literatura estadunidense (a primeira, uma reunião de contos; a segunda, um romance) têm como foco de atenção não o crescimento de um grande centro cosmopolita, mas a vida provinciana de pequenas cidades do centro-oeste dos Estados Unidos. Carl Van Doren, em 1921, escreveu uma série de artigos em que censurava esses autores por sua "revolta" contra a pequena cidade estadunidense. Quer leia-se o romance de Lewis como uma "revolta", quer como um relato em alguma medida simpático ao mundo narrado (posição que Lewis sempre defendeu, tanto em artigos quanto em palestras), o fato é que a cidade provinciana aparece, corriqueiramente, como um tópico que remete à essência do país, quase como um espaço privilegiado onde é possível observar as relações de força em jogo na vida do "americano médio"312. Conferir, para o bem ou para o mal, tratamento literário a essas cidades era lidar com uma espécie de mito nacional ${ }^{313}$, um microcosmo do país que resistia às transformações em duas frentes: resguardando as caraterísticas essenciais da construção da nação e opondo-se ao desenvolvimento desenfreado das grandes metrópoles representadas, no fim do século XIX, por Chicago e Nova York. Em sua viagem para Nova York na década de 1920, o inglês Ford Madox Ford não deixa de notar como essa é “definitivamente a única metrópole antipuritana da América",314. No panorama da vida nacional, essas duas grandes metrópoles representavam exceções.

Até 1880, os Estados Unidos eram ainda um país essencialmente agrário, com três quartos da sua população - de aproximadamente quarenta milhões, segundo um

\footnotetext{
312 "The basic civizilation of America was middle class", comenta Hilfer, ao analisar os motivos pelos quais a pequena cidade era, ao mesmo tempo, um espaço que representava quem essa nação imaginava ser e quem gostaria de ser. HILFER, Anthony Channell. The Small Town in American Realism. In: SMITH, Christopher (Ed.). American realism. San Diego: Greenhaven Press, 2000, p. 167.

${ }^{313}$ HILFER, Anthony Channell. The Small Town in American Realism, cit., p. 166.

${ }^{314}$ FORD, Madox Ford apud DOUGLAS, Ann. Terrible honesty, cit., p. 10.
} 
censo da época - residindo em regiões rurais ou pequenas cidades de menos de quatro mil habitantes ${ }^{315}$. As grandes metrópoles que se tornaram o foco de atenção em romances da virada do século (Sister Carrie, The jungle, Maggie e A hazard of new fortunes, por exemplo) eram, ao mesmo tempo, a exceção e o modelo de desenvolvimento que deveria ser exportado para todo o território nacional após o fim da Guerra Civil. Em oposição, portanto, aos romances publicados pouco antes por Sherwood Anderson ou Sinclair Lewis - que também indicavam em seus títulos um espaço geográfico -, optar por abordar o tema da metrópole revelava outro aspecto do país: não a "essência" das relações nacionais, mas certa aspiração em que o nacional se encontrava com os projetos mais eloquentes da modernização e na qual o desenvolvimento industrial ganhava impulsos mais internacionais. Se Nova York era, para o olhar estrangeiro, o grande símbolo dos Estados Unidos (ao menos a partir da primeira década do século XX), no resto do território nacional a cidade era vista com um misto de fascínio e desconfiança, quase como um corpo estranho.

Poderíamos nos perguntar, tendo em vista que Manhattan foi retratada em tantos outros romances urbanos da virada do século, qual a especificidade de Manhattan Transfer. Antes ainda, seria possível questionar o que caracterizaria um romance urbano, uma vez que a relação entre romance e cidade pertence à própria origem do gênero. Para delimitar a especificidade do que se poderia chamar de romance urbano - embora o termo não possa configurar um subgênero de fato Blanche Gelfant, em seu estudo The American city novel, estabelece uma distinção entre o romance urbano e aquelas obras em que a cidade aparece apenas como "cor local". Quando a cidade comparece no romance como "cor local", temos um pano de fundo criado por um meio da exposição de detalhes do ambiente citadino, sobre o qual as personagens agem sem que ele necessariamente determine ou influencie as suas ações. Desse modo, a substituição de um pano de fundo (digamos, Paris) por outro (como Londres) não afetaria o encadeamento da intriga. Já no caso do romance urbano, o escritor não estaria preocupado com a exposição de detalhes e pormenores ou com uma perspectiva anedótica, mas apresentaria a "vida urbana como um todo orgânico" e expressaria "uma visão da cidade coerente, organizada e completa",316. Apesar de compreender a noção de que no romance urbano há uma tentativa de expor

\footnotetext{
${ }^{315}$ Ver SCHLESINGER, Arthur Meier. The rise of the city - 1878-1898. New York: The Macmillam Company, 1969.

316 "Urban life as an organic whole, and he expresses a coherent, organized, and total vision of the city." GELFANT, Blanche. The American city novel, cit., p. 06.
} 
todo o conjunto de partes que compõem essa cidade, os termos utilizados por Gelfant (orgânico, coerente, organizado e completo) são problemáticos quando tratamos do romance de Dos Passos.

Pensemos no caso de Manhattan Transfer: pelo que já foi discutido nos capítulos anteriores, é possível afirmar que alguns dos fatores que realmente determinam a organização das partes do romance dependem de especificidades objetivas da história de Nova York. Dependem, portanto, de sua afluência massiva de imigrantes - desde a colonização, a partir de uma imigração estrangeira diversificada - e da aglomeração intensa, que exige a convivência cotidiana entre desconhecidos. Há também a potente ideologia do sucesso e da "iminente" possibilidade de ascensão social, franqueada ao homem comum, que não precisaria lutar contra uma hierarquia social rígida, herdeira de uma tradição feudal e monárquica determinando as suas chances de sucesso ${ }^{317}$. Emile, o marinheiro francês que deserta ao ancorar no porto de Manhattan, é movido pelo ideal de que "nos Estados Unidos, um cara pode avançar na vida. Nascimento não importa, educação não importa. É só avançar"’318.

Além disso, com o crescimento comercial, Nova York tornou-se conhecida também por ser um local em que, se o sucesso é possível, a concorrência é impiedosa. E, por isso mesmo, "se um homem tiver sucesso em Nova York, ele é um sucesso",319. Todos esses aspectos, concretos e ideológicos, presentes ainda hoje no imaginário que circunda Manhattan, mostram-se fundamentais para o desenvolvimento das tramas e para as relações que se estabelecem entre elas. Seria possível, talvez, indagar se esses mesmos aspectos não estariam igualmente presentes em outras metrópoles da mesma época, o que parece uma objeção plausível. Contudo, em qualquer outro contexto, esses vetores não estariam presentes todos em conjunto, nem na mesma relação de forças, nem com a mesma intensidade que vemos em Nova York.

Ao escolher essa cidade e seus dilemas como tema, Dos Passos inseriu-se em uma espécie de tradição de sua época, notadamente, a de enfrentar artisticamente os

\footnotetext{
317 "All of these 'land of opportunities' themes are traceable, historically, to the absene of a feudal past and its manifold political and ideological consquences." MARX, Leo. Pastoralism in America. In: CERCOVITCH, Sacvan; JEHLEN, Myra (Eds.). Ideology and classic American literature. New York: Cambridge University Press, 1986, p. 48.

318 "In America a fellow can get ahead. Birth dont matter, education dont matter. It's all getting ahead." DOS PASSOS, John. Manhattan Transfer, cit., p. 18.

319 "If a man's a success in New York, he's a success." DOS PASSOS, John. Manhattan Transfer, cit., p. 100.
} 
impasses colocados pelo crescimento urbano ${ }^{320}$. Todavia, o seu romance parecia, aos seus críticos contemporâneos, destacar-se dos demais justamente no que diz respeito à forma como a metrópole e seus padrões, estruturas, e dinâmicas impõem-se à narrativa. Em uma resenha de primeira hora, intitulada sugestivamente "Manhattan at Last!", Sinclair Lewis argumentou que nem Whitman (que teria escrito sobre uma “cidade provinciana perto da fronteira", e não sobre Manhattan), nem Howells, Wharton ou O. Henry teriam conseguido captar realmente a essência da cidade como Dos Passos ${ }^{321}$. Mais de dez anos depois da publicação de Manhattan Transfer, John Chamberlain ainda argumentava que se tratava da tentativa "mais bem-sucedida até hoje de pintar um retrato coletivo desse organismo enorme e espraiado que é a cidade de Nova York" ${ }^{222}$. Como caracterizar as particularidades que fizeram com que Dos Passos parecesse aos seus contemporâneos tão mais autêntico em sua representação da metrópole, como argumentou Warren Beach, comparando Dos Passos a Norris, Dreiser e Lewis ${ }^{323}$, para prejuízo desses?

Pode-se sugerir, como faz Blanche Gelfant, que a peculiaridade de Manhattan Transfer consiste no fato de a metrópole ser realmente alçada ao patamar de personagem principal. Contudo, a proposição de que Nova York é a protagonista, embora bastante recorrente ${ }^{324}$, não é evidente em si mesma - ainda que se argumente, como Gelfant, que isso seria resultado da ausência de profundidade das personagens. $\mathrm{Na}$ verdade, o simples fato de as personagens serem planas não implicaria, por si mesmo, que a metrópole deixasse de ser cenário. O crítico McLuhan, por exemplo, autor de um texto importante sobre as técnicas utilizadas em Manhattan Transfer, afirma, ao contrário, que Nova York não é nada além de um "pano de fundo fantasmagórico" sobre o qual transcorreriam as "frustrações e defeitos" das

\footnotetext{
320 "A time seems to arrive in the career of nearly all of our writers of the younger school when the challenge of New York to their imagination and descriptive powers assumes the proportions of a clear duty tha may no longer be shirked if self-respect is to be maintained." STUART, Henry Longan. Review (1925), cit., p. 64.

${ }^{321}$ LEWIS, Sinclair. Manhattan at Last!, cit., p. 71.

${ }^{322}$ CHAMBERLAIN, John. Review (1939). In: MAINE, Barry (Org.). Dos Passos. The critical heritage. New York: Routledge, 1988, p. 196.

323 "Norris and Dreiser and Lewis are honorable names in American realism, but in many points of tone and technique they belong to the past rather than to the present." [Tradução nossa.] BEACH, Joseph Warren. American fiction 1920-1940, cit., p. 34.

${ }^{324}$ Por exemplo: "As known, in Manhattan Transfer (...) the main 'character' is the city of New York.” VARELA, Ângela. John Dos Passos' Art: New York's Flashes in Manhattan Transfer. In: ABREU, Maria Zinia Gonçalves; VASCONCELOS, Bernardo Guido (Eds.). John Dos Passos. Biography and critical essays. Newcastle Upon Tyne: Cambridge Scholars Publishing, 2010, p. 89.
} 
personagens $^{325}$. Portanto, é preciso ainda demonstrar, a partir da construção literária, como essa "cidade imperial" está representada no romance.

\subsubsection{A cidade em três tempos}

A elaboração do tempo na narrativa se dá por uma intersecção de diferentes temporalidades. A primeira delas é o percurso lacunar das personagens que compõem a estrutura do romance: um tempo imperfeito, de ações que não se concluem e permanecem em baixa ressonância, meio apagadas, meio abandonadas. Todos aqueles breves episódios singulares, que se encerram em uma única cena (como a cena da Gillette ao fim do primeiro capítulo), e as trajetórias que se desenvolvem em alguns poucos episódios (como de Anna Cohen), continuam ressoando, quase imperceptivelmente, sob o desenvolvimento das narrativas de Ellen, Bud e Jimmy. Esse procedimento não se restringe a essas tramas efêmeras, mas é reiterado também no percurso daquelas personagens que aparecem de forma mais recorrente, como Ellen: quantos fios de sua história não ficam abandonados no andamento do texto, por exemplo, o aborto de seu filho, fruto da relação com Stan? Do aborto nunca mais se fala e essa cena, entre outras, permanece ecoando na estrutura do romance como as flores apagadas do carpete da casa da família Thatcher ${ }^{326}$ : quase mudos, esses muitos fios nem reaparecem, nem se deixam concluir.

A recusa de Dos Passos em aderir a uma representação diligente do universo subjetivo das personagens, buscando antes de tudo conferir objetividade à narrativa o que ele pretendia fazer a partir de sua "lente satírica"327 - gera um efeito que compromete o princípio de identificação entre leitor e personagens e, como já dissemos, gerou uma série de críticas à construção dessas personagens. Essas vidas em entreatos, repletas de hiatos e ausências, não produzem a sensação de que o

\footnotetext{
${ }^{325}$ MCLUHAN, Herbert Marshall. Dos Passos: technique vs sensibility, cit., p. 154.

326 "Ellen dropped onto the davenport and let her eyes wander among the faded roses of the carpet." Essas são, provavelmente, as mesmas flores sobre as quais Ellen, criança, dançou ouvindo "Mosquito Parede" Essa sugestão breve e discreta é interessante porque, em um romance em que tudo parece ser rompido, sugere uma continuidade, ainda que um tanto melancólica. DOS PASSOS, John. Manhattan Transfer, cit., p. 168.

327 "But to obtain the objectivity that is essential to good work he must keep his own mental processes, as well as those of the people he is describing, within the focus of his satiric lens." DOS PASSOS, John. What makes a novelist. In: PIZER, Donald (Org.). John Dos Passos: the major nonfictional prose. p. 273
} 
romance representa uma "dense continuity of living tissue"328. A expressão foi utilizada por Claude-Edmonde Magny para opor Dos Passos a uma representação do “tempo vivido", presente mesmo nas breves vinte e quatro horas de Mrs. Dalloway em Dos Passos, não há um desenvolvimento orgânico do tempo, em que as partes se relacionam. O tempo imperfeito do romance de Dos Passos marca o percurso das personagens e determina a estrutura da própria metrópole.

A segunda temporalidade dessa armadura estrutural é o tempo coletivo dos grandes acontecimentos históricos e das pequenas notícias, casos e eventos ligados diretamente à metrópole - ambos transmitidos pelos jornais ou comentados nos diálogos das personagens. Por um lado, a Grande Guerra, a Batalha Russo-Japonesa; por outro, os acontecimentos mais próximos e pedestres, como a consolidação de Nova York ou o assassinato verídico de Stanford White, que motiva os comentários indignados de Phil Sandbourne. Esses fatos que aparecem como moldura dos episódios fictícios, organizando a cronologia dentro de cada trajetória e dessas entre si, são responsáveis também por assentar a armadura ficcional no chão da cidade histórica: a moldura dos fatos reforça o sentido de mudanças que vemos no romance. Por exemplo, observamos, no transcorrer dos capítulos, a referência cada vez mais constante aos veículos motorizados, que vão tomando o lugar, nas ruas, das carruagens a cavalo - processo que objetivamente ocorreu em Nova York no período compreendido pelo arco da narrativa. No romance, um dos eventos mais marcantes é o acidente de Gus McNiel, cujo atropelamento na $10^{\text {a }}$ Avenida faz a fortuna de sua família e a fama do jovem advogado George Baldwin. $\mathrm{O}$ aspecto realmente revelador desse acidente, aparentemente corriqueiro, é a referência espacial específica: conhecida como a "Avenida da Morte", no fim do século XIX, a $10^{\mathrm{a}}$ Avenida era palco de uma série de acidentes ocasionados após a instalação dos trilhos ao nível da rua. A atenção que Dos Passos conferiu a esses detalhes fortalece a relação entre a representação e a experiência histórica, de acordo, aparentemente, com o projeto de "objetividade" do autor: acontecimentos que poderiam realmente ter ocorrido em uma moldura espaço-temporal reconhecível. A figura a seguir é uma ilustração, coincidentemente do ano da consolidação de Nova York (1896) e da manchete lida por Ed Thatcher na abertura do segundo capítulo. Publicada no New York World, um jornal sensacionalista de alta tiragem na virada do século, a ilustração estampa um

\footnotetext{
${ }^{328}$ MAGNY, Claude-Edmonde. Time in Dos Passos. In: HOOK, Andrew (Ed.). Dos Passos: a collection of critical essays. New Jersey: Prentice-Hall, Inc., 1974, p. 132.
} 
bonde da linha Mount Vernon, que corria nos trilhos da Terceira Avenida, atropelando um pedestre desavisado.

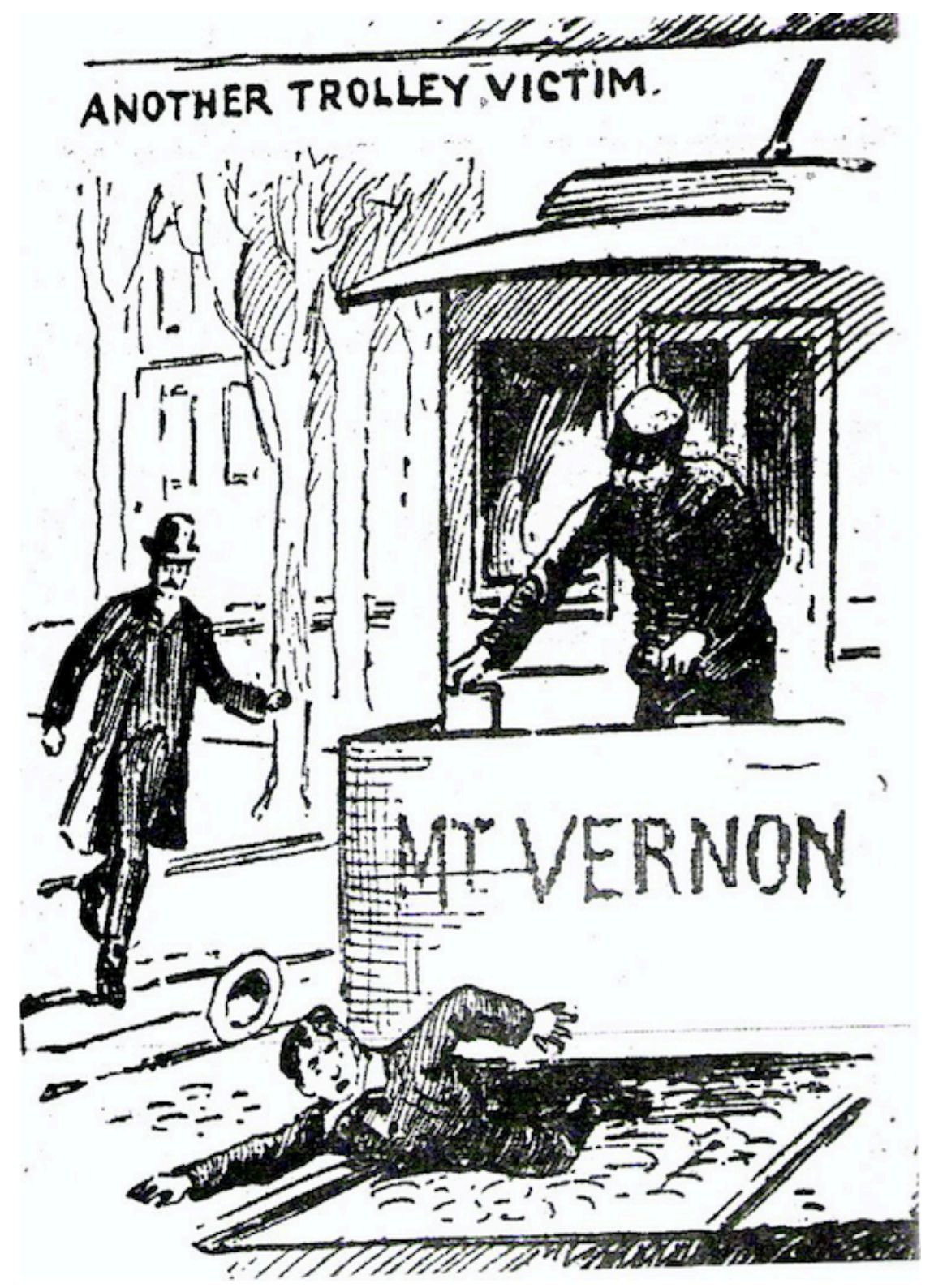

Figura 8 - "Mais uma vítima do bonde", New York World, 1896.

A terceira temporalidade em jogo é o que podemos denominar tempo industrial, ou seja, o tempo da metrópole, que mantém a sua dinâmica, inalterado tanto pelos grandes acontecimentos da história quanto pelos pequenos incidentes das vidas que a compõem. O seu tempo não é o tempo orgânico, o qual em cada parte possui uma duração significativa, e sim o tempo homogêneo da produção industrial, em que se suprime a noção de qualidade e diferença. 


\subsubsection{Paisagem em movimento}

Por um lado, portanto, o romance é animado por essas pequenas referências históricas que fornecem aos fatos fictícios o efeito de real capaz de promover uma representação daquela época e daquele espaço determinados, tal como Dos Passos pretendia. Por outro, há uma abundância de referências cartográficas que impregnam a história e a imaginação do leitor. O primeiro capítulo do romance se abre com um espaço ainda vago: uma balsa atraca em um porto anônimo; um bebê nasce em uma maternidade não identificada. A primeira referência geográfica é feita por Bud, que aporta em um quarteirão a leste da avenida Broadway, indicando o norte da ilha de Manhattan. No episódio seguinte, Ed Thatcher e o Sr. Zucker tomam uma cerveja na Terceira Avenida e, no fim do capítulo, um homem barbudo passeia pelas ruas Allen e Canal. Daí em diante, as referências tornam-se profusas (além das ruas e avenidas, há também dados como a estátua do General Sherman e o restaurante Delmonico's) e preenchem as lacunas entre os diferentes episódios, reunindo-os em um mapa imaginário onde os nomes por vezes se repetem e a Broadway cruza as diferentes intrigas como a avenida - antiga trilha indígena - atravessa a ilha na diagonal.

A partir dessa "nomeação" o romance procura registrar a "realidade material” ${ }^{329}$, fotográfica, da cidade. O referencial promovido pela repetição de topônimos é reforçado também pela alusão aos eventos históricos retratados como notícias ou aludidos em conversas (por exemplo, as deportações de 1919-1920 ou o incêndio e naufrágio do navio General Slocum). São esses os mesmos eventos que também ancoram, cronologicamente, as intrigas e que, pelas correspondências que estabelecem, ajudam a sugerir não só a materialidade mas a historicidade da cidade. Além disso, temos os ready-mades - as propagandas, as placas e cartazes, as canções - de que o narrador dispõe ao longo de toda a narrativa e que fortalecem o aspecto plástico do texto. Todos esses são recursos que procuram dar conta da materialidade urbana. O acúmulo de referências hodonímicas, contudo, não vai de par, como seria de se esperar, com uma "infatigável nomeação do detalhe" ${ }^{\text {"330 }}$ nem com a preocupação por sua exatidão. Ao comparar o estilo de Dos Passos ao de Dreiser, Blanche Gelfant nota como no último é possível observar um esforço de catalogar "detalhes reais",331,

\footnotetext{
${ }^{329}$ ALTER, Robert. Imagined cities, cit., p. ix.

${ }^{330}$ MORETTI, Franco. O século sério, cit., p. 844.

${ }^{331}$ GELFANT, Blanche. The American city novel, cit., p. 142.
} 
resultando em um tipo de descrição em tudo diferente daquele que encontramos em Manhattan Transfer.

No romance de Dos Passos, esses detalhes se perdem na forma descontínua do texto, engolidos em sua cadência maquinal. Embora haja uma profusão de nomes de ruas, a sua descrição não é extensiva, ou seja, não se dá pela forma "catalogar" do romance realista, em que o acúmulo de detalhes criava a "ilusão de uma representação compreensiva" ${ }^{332}$.

28) Sudden jetbright glances of eyes under straw hats, attitudes of chins, thin lips, pouting lips, Cupid's bows, hungry shadow under cheekbones, faces of girls and young men nuzzled fluttering against her like moths as she walked with her stride even to his through the tingling yellow night. ${ }^{333}$

29) Jimmy nodded wisely, slipped past the staring buttons of the doorman and out onto Broadway full of clangor and footsteps and faces putting on shadowmasks when they slid out of the splotches of light from stores and arclamps. He walked fast uptown past the Ansonia. In the doorway lounged a blackbrowed man with a cigar in his mouth, maybe a kidnapper. But nice people live in the Ansonia like where we live. Next a telegraph office, drygoods stores, a dyers and cleaners, a Chinese laundry sending out a scorched mysterious steamy smell. He walks faster, the chinks are terrible kidnappers. Footpads. A man with a can of coaloil brushes past him, a greasy sleeve brushes against his shoulder, smells of sweat and coaloil; suppose he's a firebug. The thought of firebug gives him gooseflesh. Fire. Fire. ${ }^{334}$

Nesses dois trechos, temos a representação de personagens percorrendo os espaços públicos da própria cidade. No plano narrativo, nada acontece de fato, não há um sequestro (fantasma que ronda continuamente a imaginação das crianças do romance) e nenhuma aventura - o que condiz, como já vimos, com a tendência geral do livro. O efeito que esse trecho produz é o da imersão em um ambiente repleto de desconhecidos, sem uma organização aparente em que o fluxo aparece aleatório. Para expressar as sensações decorrentes de um passeio pelas vias públicas de uma

\footnotetext{
${ }^{332}$ ALTER, Robert. Imagined cities, cit., p. 56.

333 "Súbitas espiadas pretobrilhantes de olhos sob chapéus de palhas, queixos convencidos, lábios finos, lábios grossos, lábios de coração, sombras famintas sob maçãs de rostos, caras de meninas e de jovens, revoavam fuçando contra ela como mariposas enquanto ela andava com seus passos junto aos dele pela agitada noite amarela." [Tradução nossa]. DOS PASSOS, John. Manhattan Transfer, cit., p. 129.

334 "Jimmy meneou a cabeça prudentemente, passou pelos botões observadores do porteiro e saiu para a Broadway cheia de estrondos e passos e rostos vestindo máscarasdesombras ao saírem das manchas de luz das lojas e das lâmpadas de arco. Ele andou rápido pro norte passando o Ansonia. Na entrada preguiçava um homem sombrio com um cigarro na boca, talvez um sequestrador. Mas tem gente boa no Ansonia assim como onde a gente vive. Depois um telégrafo, lojas de tecidos e tinturaria, uma lavanderia chinesa soltando um misterioso cheiro queimado vaporoso. Ele aperta o passo, os china são sequestradores horríveis. Assaltantes. Um homem com uma lata de querosene passa raspando nele, uma manga oleosa raspa no ombro dele, cheiros de suor e querosene; imagina se ele for um incendiário. Pensar em incendiários o deixou arrepiado. Fogo. Fogo.”DOS PASSOS, John. Manhattan Transfer, cit., p. 69.
} 
metrópole, a concatenação de imagens sem ligação sintática produz uma atmosfera de profusão e confusão.

Esse recurso metonímico, aliado a uma enumeração frenética, deixa o texto carregado de hiatos, espaços vazios no centro da paisagem, pois prescinde da exposição exaustiva do detalhe: pelo contrário, o resultado é um tipo de efeito sugestivo, capaz de criar uma imagem sensível do ambiente. Em um ensaio muito importante e bastante comentado sobre o romance, "Technique and sensibility", McLuhan argumenta que a diferença entre a representação da cidade em Manhattan Transfer e em Ulisses, de Joyce, residiria no fato de que, embora ambos utilizem a mesma "paisagem descontínua", há uma inclinação "impressionista" em Dos Passos que se opõe à mistura de naturalismo e simbolismo empregada por Joyce. O procedimento do autor estadunidense seria capaz de gerar um "espectro completo dos mundos externo e interno" 335 .

O crítico está correto ao apontar a descontinuidade da paisagem, certa decomposição das partes na apresentação do todo, em consonância, aliás, com o tom geral das duas obras, e em argumentar que, apesar da elaboração das técnicas serem similares, o efeito resultante nos dois romances não é o mesmo. Contudo, há uma imprecisão na identificação do estilo de Dos Passos com a técnica do impressionismo. Esse último, como apontou Merleau-Ponty ao se referir ao âmbito das artes plásticas, procura restituir, pela "decomposição" do tom local, uma "verdade geral da impressão" 336 . Há no impressionismo uma tentativa de restabelecer, por meio da concentração da técnica artística nas condições de apreensão subjetiva, uma noção de totalidade das relações entre luz, objeto e atmosfera. Dessa forma, um quadro capta a vista da catedral a partir de um ponto fixo em determinada hora do dia, confiando na objetividade daquela impressão específica.

Observando os trechos descritivos que destacamos nas páginas anteriores, nota-se muito menos um interesse em estabelecer um quadro pela impressão ou exposição da relação dos objetos entre si ou nas ressonâncias das cores do que em fortalecer a autonomia das partes, a descontinuidade dos fragmentos e, às vezes, as suas contradições por meio da deformação. A descrição dos espaços físicos da cidade é menos a cidade absorvida pelo sujeito, do que um espaço que só pode ser

\footnotetext{
${ }^{335}$ MCLUHAN, Herbert Marshall. Dos Passos: technique vs sensibility, cit., p. 153.

${ }^{336}$ MERLEAU-PONTY, Maurice. Cézanne's doubt. In: TOADVINE, Ted; LAWLOR, Leonard (Eds.). The Merleau-Ponty reader. Evanston: Northwestern University Press, 2007, p. 71.
} 
apreendido como pura fragmentação, no qual se projetam as ansiedades coletivas autonomização dos elementos como a perda de controle sobre as máquinas e os objetos fabricados; o sequestro como ansiedade em relação aos desconhecidos fisicamente tão próximos. Deformados pela projeção, os espaços físicos não formam a identidade dessa metrópole, mas seguem indefinidos. Por mais vívidos que sejam os esquetes narrativos, a sua construção não resulta em uma unidade visual. Mais do que um quadro, uma construção visual, a cidade literária é uma força, uma dinâmica.

A paisagem em movimento do romance é elaborada a partir da justaposição irregular de partes. Essa composição é armada em forma de sinédoque, e um de seus efeitos é demonstrar a impossibilidade de compreensão do todo, porque, ao rés do chão, a visão é marcada por hiatos e não há panorâmica possível. A descontinuidade que trunca também o desenvolvimento das tramas é responsável, ainda, por gerar um ritmo de leitura acelerado que condiz com a experiência da velocidade instaurada pelos novos meios de transporte (aos quais faz menção o próprio título do romance) e pela aglomeração e fluxo de pessoas. A aglomeração em si, típica de centros urbanos, também poderia ser interpretada como uma espécie de concatenação irregular de partes autônomas e independentes no espaço físico. Esse ritmo acelerado e essa descontinuidade se desdobram, no tempo e no espaço literários, nas pequenas e grandes intrigas que formam a malha narrativa do romance.

Tal como as descrições das personagens são lacunares, cheias de omissões, marcadas por detalhes que se sobressaem, a construção literária da cidade também é avessa a uma exposição compreensiva e totalizante. Robert Alter caracteriza o narrador de Balzac como um "authoritative guide to Paris" ${ }^{337}$ : nada foge a seu controle e a seu estilo de "inventário",338. Em Manhattan Transfer, o romance não almeja uma descrição capaz de exaurir o espaço. O que percebemos nas cenas já comentadas é o fato de que a cidade sempre aparece, a partir do caminho das personagens, em movimento: na chegada de uma balsa ao porto, na caminhada de Jimmy pela Broadway ou quando Ellen e Stan percorrem, desatentos, as ruas da cidade:

\footnotetext{
${ }^{337}$ ALTER, Robert. Imagined cities, cit., p. 8. A caracterização de Alter pode parecer oposta à que de Balzac diz o crítico Georg Lukács, para quem o escritor realista seria um dos contraexemplos do "caráter completo de inventário" presente em Zola Contudo, Alter está enfatizando, aqui, a descrição do espaço da cidade. Lukács também não nega a presença da descrição em Balzac, mas elogia a organização desta com o "elemento dramático".. (LUKÁCS, Georg. Narrar ou descrever. In: Ensaios sobre literatura. Rio de Janeiro: Civilização Brasileira, 1965, p. 47).

${ }^{338}$ ALTER, Robert. Imagined cities, cit., p. 9.
} 
30) In the heavy heat streets, stores, people in Sunday clothes, strawhats, sunshades, surfacecars, taxis, broke and crinkled brightly about her grazing her with sharp cutting glints as if she were walking through piles of metalshavings. She was groping continually through a tangle of gritty sawedged brittle noise ${ }^{339}$.

Mesmo nos breves trechos em que a construção da cena parece independente da ação das personagens, há algum elemento que assume a função de sujeito para tornar dinâmica a cena potencialmente estática:

31) The rain advanced down the street in a solid sheet glimmering, swishing, beating newspapers flat, prancing in silver nipples along the asphalt, striping windows, putting shine of the paint of streetcars and taxicabs ${ }^{340}$.

Não há minúcia referencial na descrição que aparece nessas cenas. Poderíamos nos perguntar mesmo se o termo mais preciso para designar esses momentos do texto é ainda "descrição". A personificação da chuva contrasta com a completa ausência de pessoas na cena. Não há pessoas molhadas, fugindo para abrigar-se, mas uma autonomização de elementos muito urbanos sendo quase tocados pela água que age, tal como um pintor recria e distorce o mundo "natural". Embora o efeito plástico seja vívido, a cena não é exata. Ao contrário, há algo quase negligente nesses quadros que não chegam a formar um conjunto passível de ser reconstituído pelos dados oferecidos no texto.

Por aparecer, na maioria das vezes, em um processo de deslocamento, ou seja, quando as personagens circulam pela ilha (ou as coisas tornam-se pessoas e estão em movimento, como a chuva), as imagens parecem em alguma medida irrecuperáveis: a composição de cada espaço não vai se repetir a partir dos mesmos elementos. O que se repete é essa sensação de uma força que se movimenta e estabelece uma relação direta com as personagens que atravessam os espaços.

32) Arm in arm they careened up Pearl Street under the drenching rain. Bars yawned bright to them at the corners of rainseething streets. Yellow light off mirrors and brass rails and gilt frames round pictures of pink naked women was looped and slopped into whiskyglasses guzzled fiery with tipped back head, oozed bright through the blood, popped bubbly out of ears and eyes, dripped spluttering off fingertips. The raindark houses heaved on either side, streetlamps swayed like lanterns carried in a parade, until Bud was in a back room full of nudging faces with a woman on his knees. ${ }^{341}$

\footnotetext{
339 "Sob o calor intenso, ruas, lojas, gente em roupa de domingo, chapéusdepalha, sombrinhas, bondes, táxis irrompiam e zuniam reluzentes à sua volta resvalando nela com brilhos afiados como se estivesse andando por pilhas de estilhaços de metal. Ela ia tateando por um emaranhado de barulhos arenosos, afiados e quebradiços". [Tradução nossa] DOS PASSOS, John. Manhattan Transfer, cit., p. 115.

340 "A chuva avançava rua abaixo num sólido lençol, tremeluzir, sibilando, achatando as folhas de jornais, empinando em bicos prateados pelo asfalto, riscando janelas, pondo brilho na pintura dos bondes e táxis". [Tradução nossa]. DOS PASSOS, John. Manhattan Transfer, cit., p. 175.

${ }^{341}$ DOS PASSOS, John. Manhattan Transfer, cit., p. 79
} 
No trecho em questão, temos apenas uma indicação de localização espacial: a rua Pearl no sul da ilha de Manhattan. Além da chuva, que reaparece em uma espécie de anominação ${ }^{342}$ evidente na construção de adjetivos (raindark, rainseething) e se trata de um elemento objetivo da cena (afinal, realmente chove), o principal aspecto que permeia toda a descrição é da ordem da experiência subjetiva, a embriaguez de Bud e seu recente amigo. Assim, temos looped e guzzled, expressões informais para "bêbado" ou "intoxicado" que são atribuídas a objetos inanimados, a luz e o uísque que Bud entorna. Embora pudéssemos sugerir que se trata de uma hipálage ("yellow light was looped and slopped... into whiskyglasses"), em que a luz que reflete nos espelhos e molduras assume as características do líquido ingerido, ela na verdade se associa ao uísque que desce, "queimando", pela garganta de Bud. Por meio da prosopopeia, as casas oscilam embriagadas (vale notar que heave também é "vomitar" - próximo do campo semântico em jogo) e os postes de luz vacilam como um bêbado caminhando pela rua. É curioso que mesmo no momento em que temos uma projeção da experiência individual da embriaguez, ocorre com a paisagem e objetos exatamente o mesmo processo observado nos outros trechos: fragmentação e autonomização dos elementos inanimados. Nada similar ao que pode ser observado em um romance convencionalmente descritivo.

\begin{abstract}
It was one of those cross streets peculiar to Western cities, situated in the heart of the residence quarter, but occupied by small tradespeople who lived in the rooms above their shops. There were corner drug stores with huge jars of red, yellow, and green liquids in their windows, very brave and gay; stationers' stores, where illustrated weeklies were tacked upon bulletin boards; barber shops with cigar stands in their vestibules; sad-looking plumbers' offices; cheap restaurants, in whose windows one saw piles of unopened oysters weighted down by cubes of ice, and china pigs and cows knee deep in layers of white beans. At one end of the street McTeague could see the huge power-house of the cable line ${ }^{343}$.
\end{abstract}

Observando o trecho anterior, retirado do romance de Frank Norris, McTeague, publicado em 1899, podemos notar como o narrador oferece ao leitor o que convencionalmente pode-se esperar de uma descrição realista (ou, para ser mais fiel às ambições teóricas do próprio Norris, naturalista): precisão e detalhamento. A rua ganha vida diante dos olhos do leitor: sabemos que é uma mistura de comércio e residências; vemos a fachada tristonha das lojas, sentimos o cheiro dos alimentos

\footnotetext{
${ }^{342}$ Figura de linguagem morfossintática que consiste em empregar ou criar várias palavras com um mesmo radical.

${ }^{343}$ NORRIS, Frank. McTeague. A story of San Francisco. In: The Library of America. 1986. p, 265. Novels and essays. Nova York:
} 
misturados nos restaurantes baratos. Dreiser, que publicou o seu Sister Carrie logo após McTeague, não compartilha a mesma inclinação pela descrição meticulosa, mais preocupado com a impressão que os detalhes causam em sua personagem (por exemplo, a forma como Carrie vê brilho e ouro em todos os lugares luxuosos nos quais entra). Contudo, ele ainda imbui o seu narrador da tarefa de apresentar de forma imparcial, mas informada e esclarecedora, o ambiente no qual se desenrola a vida de suas personagens:

Before following her in her round of seeking, let us look at the sphere in which her future was to lie. In 1889 Chicago had the peculiar qualifications of growth which made such adventuresome pilgrimages even on the part of young girls plausible. Its many and growing commercial opportunities gave it widespread fame, (...) It was a city of over 500,000, with the ambition, the daring, the activity of a metropolis of a million ${ }^{344}$.

É fácil perceber como esse impulso descritivo é reflexo de um esforço informativo, uma apresentação e registro das condições sociais de sua época. E é interessante notar como no romance de Dreiser a descrição dos espaços privados é muito mais detalhada do que a dos espaços públicos, das ruas e da cidade.

O romance de Dos Passos articula de formas diferentes o impulso documental que vemos realizado nos dois textos ficcionais mencionados. $\mathrm{O}$ espírito de representação das condições sociais das obras de Dreiser e Norris, que não tenta reconciliar indivíduo e sociedade, mas expõe as contradições e os problemas que persistem, está presente em Manhattan Transfer. Contudo se, nessa medida, o romance de Dos Passos permanece associado ao realismo histórico do fim do século XIX, não podemos esquecer que ele é o primeiro romance modernista dos Estados Unidos e instaura outro tipo de relação com a representação do espaço e outro método de descrição - o que transforma, por sua vez, o próprio conceito de objetividade tantas vezes mencionado nos escritos teóricos de Dos Passos. Nesse sentido, a que se oporia essa objetividade, posto que ela também não pode ser associada, em Manhattan Transfer, à convencional exposição exaustiva dos detalhes visíveis?

Um exemplo que talvez seja oportuno para iluminar a singularidade da obra de Dos Passos é o romance, este também modernista, de Louis Aragon, O camponês de Paris, publicado um ano após Manhattan Transfer.

${ }^{344}$ DREISER, Theodore. Sister Carrie, cit., p. 
Não quero mais me abster dos erros de meus dedos, dos erros de meus olhos. Sei agora que eles não são armadilhas grosseiras, mas sim curiosos caminhos em direção a um objetivo que nada, além deles, pode me revelar ${ }^{345}$.

O camponês de Aragon, contemplando com o olhar sempre renovado de quem chega de fora da metrópole, é capaz de enxergar com o "sentimento do maravilhoso cotidiano"346. Esse ponto de vista é fundamental para a construção do romance de Aragon, mas, ainda assim (ou talvez, justamente por causa disso), quando a cidade parece exigir o direito de ganhar expressão narrativa, a descrição do espaço assume a forma cartograficamente minuciosa de um relato de percurso:

O táxi que nos levava com nossa maquinaria de sonhos, tendo atravessado pelo lado direito da interminável rue La Fayette o nono e o décimo arrondissements, na direção sudoeste-nordeste, atingiu enfim o décimo-nono nesse ponto preciso que trazia o nome da Alemanha antes do de Jean Jaurès, onde por um ângulo de aproximadamente cento e cinquenta graus, aberto na direção sudeste, o canal Saint Martin se une ao canal do Ourcq, na saída da Bacia de La Villette, ao pé dos grandes edifícios da Alfândega, na esquina dos bulevares exteriores e do metrô aéreo que reúne irrisoriamente esses dois extremos, Nation e Dauphine, diante da companhia de Petites Voitures, do café de La Rotonde e do café da La Mandoline, a dois passos da rue Louis-Blanc, onde Le Libertaire tem sua sede, ao norte do feudo da sífilis e ao sul do Serviço fúnebre, entre os armazéns gerais de La Villette e as oficinas de materiais das estradas de ferro do Norte ${ }^{347}$.

Inicialmente, vale notar que a extensão da citação é intencional: toda a descrição é composta de uma única frase que parece simular o próprio ato de percorrer o espaço. $\mathrm{O}$ acúmulo de informações não acarreta, no caso do romance de Aragon, uma desordenação do espaço. Pelo contrário, apesar das mudanças ocorridas

\footnotetext{
${ }^{345}$ Tradução de Flávia Nascimento do original: "Je ne veux plus me retenir des erreurs de mês doigts, des erreurs de mês yeux. Je sais maintenant qu'elles ne sont pas que des pièges grossiers, mais de curieux chemins ver un but que rien ne peut me révéler, qu'elles". ARAGON, Louis. Le paysan de Paris. Paris: Gallimard, 2007, p. 149/ NASCIMENTO, Flávia Cristina de Souza. O camponês de Paris, de Louis Aragon (tradução comentada), 1991, 266f., (Doutorado). Campinas: Universidade Estadual de Campinas, 1991. p. 31.

${ }^{346}$ Tradução de NASCIMENTO, Flávia Cristina de Souza. O camponês de Paris, de Louis Aragon (tradução comentada), 1991, 266f., (Doutorado). Campinas: Universidade Estadual de Campinas, 1991. p. 31 .

${ }^{347}$ Tradução de Flávia Nascimento do Original: "Le taxi qui nous emportait avec la machinerie de nos rêves ayant franchi par la ligne droite de l'interminable rue La Fayette le neuvième et le dixième arrondissement en direction sud-ouest nor-est, atteignit enfin le dix-neuvième à ce point précis qui portait le nom de l'Allemagne avant celui de Jean Jaurès, où par un angle de cent cinquante degrès environ, ouvert vers le sud-est, le canal Saint-Martin súnit au canal de l'Ourcq, à l'issue du Bassin de la Villette, au pied des grands bâtiments de la Douane, au coude des boulevards extérieurs et du métro aérien qui réunit dérisoirement ces deux extrêmes, Nation et Dauphine, devant la compagnie des Petite Voitures, le café de la Rotonde et le café da Mandoline, à deux pas de la rue Louis-Blanc où Le Libertaire a son siège, au nord du fief de la vérole et au sud des Pompes funèbres, entre les magasins géneraux de la Villette et les ateliers du matériel roulant des chemins de fer du Nord". ARAGON, Louis. Le paysan de Paris, cit., p.284 / NASCIMENTO, Flávia Cristina de Souza. O camponês de Paris,cit. p. 157-158
} 
no decorrer de quase um século, é possível ainda hoje reconhecer o itinerário dos três amigos em direção ao parque de Buttes Chaumont. No que diz respeito à descrição desse trajeto e de seus recantos, parece que há um impulso de recolher e conservar esse mundo que possui "uma desordem impensável" e que está sempre às vésperas de mais um processo de destruição (a Passage de L'Ópera foi demolida, como já era previsto pelo narrador, no ano seguinte à escrita do romance-pesquisa de Aragon). O camponês fixa literariamente, portanto, esse mundo. Note-se como, embora as personagens estejam em um táxi em movimento, atravessando também o espaço da metrópole, a paisagem é estática, retida, contida. Há algo do colecionador nessa inclinação demorada do narrador.

Os objetivos do experimento modernista de Aragon são, certamente, muito diferentes daqueles de John Dos Passos, mas a contraposição pode ajudar a iluminar certos aspectos de Manhattan Transfer, no qual a cidade aparece como uma força, algo em movimento, e não uma somatória de espaços bem definidos. Embora, como já apontamos, a indicação de ruas e espaços públicos de Manhattan esteja reiteradamente presente durante todo o romance, a ela se sobrepõe uma série de impressões que colocam em questão a possibilidade ou mesmo a necessidade de registrar o espaço a partir de uma suposta fidelidade ao referente. $O$ romance de Aragon concede ao narrador do Camponês de Paris um tempo estendido, que ele toma para si e dedica à cidade. Essa disponibilidade do tempo é completamente negada no romance de Dos Passos, com o seu espaço dominado por um ritmo que se assemelha à produção industrial, às máquinas, de lazer e trabalho, mencionadas repetidamente em seu texto. E isso reforça a nossa sugestão anterior de que o tempo dessa metrópole é o tempo maquinal da produção em escala industrial.

Comparando o romance francês e o estadunidense, vemos que a descrição termina por assumir feições contraditórias. Para analisar os efeitos gerados nesses trechos, talvez seja iluminador pensarmos na noção de "evento" ou "acontecimento", tal como foi formulada por Moretti ${ }^{348}$. Ou seja, de que forma essa suspensão do enredo se relaciona ao encadeamento dos eventos e quais os seus efeitos para a fatura da obra? O caso de $O$ camponês de Paris é bastante singular nesse sentido, porque a própria noção de acontecimento ou ação está em xeque - nada acontece no romance, não há eventos ou intrigas, e as descrições são longas, demoradas. Já no romance de

\footnotetext{
${ }^{348}$ Ver MORETTI, Franco. O século sério, cit.
} 
Dos Passos, o papel da descrição é, via de regra, bastante reduzido, tomando algumas poucas linhas por página e, como se trata de um romance em que as ações são descontínuas, essas passagens não instauram uma grande ruptura - as rupturas são parte constitutiva do próprio encadeamento das intrigas. As suas descrições, como vimos, estão sempre permeadas pela subjetividade das personagens e dificilmente parecem sugerir observação e expressão passiva de dados meramente materiais. Entretanto, no que resulta a soma de subjetividades ceifadas, que não se completam e com as quais o leitor nem sequer tem tempo de se acostumar? A descrição reforça, na verdade, a estrutura geral do romance, reitera o seu princípio estilístico: a cidade é mais do que uma paisagem descontínua, ela é uma armação de partes autônomas, com uma dinâmica seca.

\section{4 "I remember when it was all meadows"}

A dinâmica da metrópole aparece nas epígrafes de cada capítulo. Como poemas em prosa ou quadros vivos, essas epígrafes apresentam cenas independentes tanto entre si quanto em relação ao conteúdo das tramas no romance. De toda forma, à exceção de uma (a última do romance), todas elas retratam algum tipo de cena urbana sem que, na maioria das vezes, haja uma indicação precisa de local ou data. A primeira epígrafe (discutida no segundo capítulo) trata do influxo diário de pessoas à cidade por meio da balsa. A segunda ${ }^{349}$, por sua vez, traz uma ideologia difundida sobre o futuro de Nova York como a segunda maior metrópole do mundo. Em seguida, são apresentadas cenas de imigrantes chegando à "terra das oportunidades" (terceiro e quarto capítulos da primeira parte) ${ }^{350}$, anônimos indo e voltando do trabalho (primeiro e terceiro capítulos da segunda parte), indo e voltando dos espaços de lazer (quarto e quinto capítulos, também da segunda parte). Ainda na segunda parte do romance, há a descrição de um passeio de montanha-russa: mantendo, de forma consistente, o caráter impreciso dessas epígrafes, o brinquedo em si não é nomeado, mas sugerido por toda a construção da cena. Tampouco o espaço é identificado. Podemos apenas especular que se trate de Coney Island quando o narrador cita a balsa operada pela companhia Iron Steamboat e, mais especificamente, o Luna Park, pela ênfase dada às luzes do parque. Curiosamente, é o capítulo seguinte, e não esse, que tem por título

\footnotetext{
${ }^{349}$ DOS PASSOS, John. Manhattan Transfer, cit., p. 11.

${ }^{350}$ DOS PASSOS, John. Manhattan Transfer, cit., p. 41 e 65.
} 
Rollercoaster, o que mostra a relação, em geral, pouco evidente na segunda e terceira parte do romance, entre esses três grandes elementos do romance: os títulos, as “epígrafes" e o conteúdo temático de cada capítulo.

Essas cenas de abertura, aqui chamadas de "epígrafes", heterogêneas tanto no estilo quanto no tema, ajudam a realçar a presença da cidade como uma força em movimento constante - uma potência dinâmica cuja ação sobre as partes que a compõem tende a exercer pressão e gerar um nivelamento:

33) Dusk gently smooths crispangled streets. Dark presses tight the steaming asphalt city, crushes the fretwork of windows and lettered signs and chimneys and watertanks and ventilators and fireescapes and moldings and patterns and corrugations and eyes and hands and neckties into blue chunks, into black enormous blocks. Under the rolling heavier heavier pressure windows blurt light. Night crushes bright milk out of arclights, squeezes the sullen blocks until they drip red, yellow, green into streets resounding with feet. All the asphalt oozes light. Light spurts from lettering on roofs, mills dizzily among wheels, stains rolling tons of sky ${ }^{351}$.

Esse trecho abre o quinto e último capítulo da primeira parte de Manhattan Transfer. Como acontece durante toda essa parte da obra, a relação que a epígrafe estabelece com o título e com os segmentos que compõem o capítulo é menos enigmática do que nas partes subsequentes. O título é, em referência imediata à epígrafe, Steamroller (rolo compressor), e a cena começa com uma alegoria da noite como um rolo compressor. O interessante dessa alegoria (uma metáfora continuada) é o fato de que nenhum dos termos é definido claramente, sobretudo no que diz respeito à noite. Noite seria o tempo que transcorre? Ou ainda a vida na cidade? Como é comum no caso da alegoria, um significado não exclui, necessariamente, o outro. $\mathrm{O}$ que começa como "crepúsculo" (dusk) vira “escuro" (dark) para, finalmente, tornar-se "noite" - passagem do tempo que pode ser lida como uma simples descrição poética da escuridão que avança e das luzes elétricas que começam a brilhar. Sem dúvida, o trecho incorpora esses elementos, mas também sugere a passagem do tempo em sentido mais profundo, como algo que exerce uma força tanto sobre as coisas quanto sobre as pessoas, sem distingui-las. Assim como pressiona e esmaga (crushes) o

\footnotetext{
351 "Crepúsculo delicadamente suaviza as ruas pontanguladas. Escuro pressiona firme a cidade de asfalto fumegante, esmaga a moldura das janelas e dos letreiros luminosos e chaminés e caixa d'águas e ventiladores e escadas de incêndio e cornijas e ornamentações e ondulações e olhos e mãos e gravatas em nacos azuis, em enormes blocos pretos. Sob a mais mais forte pressão rolante janelas expelem luz. A noite comprime leite brilhante dos postes de luz, espreme os blocos soturnos até que eles gotejem vermelho, amarelo, verde nas ruas ressoando a passos. Todo o asfalto transpira luz. A luz jorra dos letreiros nos telhados, gira atordoada entre rodas, mancha toneladas rolantes de céu." [Tradução nossa.] DOS PASSOS, John. Manhattan Transfer, cit., p. 94.
} 
batente das janelas, os letreiros, as chaminés e os ventiladores, ela também prensa olhos, mãos e gravatas em um mesmo avançar maquinal. A expressividade poética dessa passagem se deve à imagem construída pela alegoria em movimento. $\mathrm{O}$ avanço dessa força que é meio máquina, meio natureza, ganha intensidade também com o uso do polissíndeto (repetição de conjunção), que, além de estabelecer uma relação de igualdade entre os elementos que coordena, exprime uma impressão de velocidade e de uma força que se movimenta em intervalos idênticos. A repetição de termos de um mesmo campo semântico ("steamroller", "rolling", "wheel", "mill”) acentua o movimento incessante agindo sobre todos os elementos que, de uma forma ou de outra, acabam em o seu caminho. Se os objetos espremidos por essa força noturna terminam por “drip red" (ou “drop dead"?), é precisamente a fuga das luzes escapando junto aos passos que não deixam de ressoar que faz com que o trecho em si não se torne tão claustrofóbico e opressor.

$\mathrm{O}$ movimento maquinal dessa cidade, nesse ímpeto de nivelamento e compressão, está relacionado ao já comentado processo de apagamento das individualidades (e, nessa medida, da memória e das histórias individuais) e o sentimento de totalização do espaço que exclui qualquer representação de acontecimentos que se desenrolem fora dos limites geográficos da metrópole. Excluído o espaço campestre, rural, como contraposição à cidade, excluídas também as antigas capitais do velho mundo onde transcorre a Guerra Mundial, Nova York apaga tanto os espaços quanto a história, seu próprio passado. O caráter efêmero de sua construção foi notado por Henry James, que comenta em The American scene (1907):

Crowned not only with no history, but with no credible possibility of time for
history, and consecrated by no uses save the commercial at any cost, they [the
skyscrapers] are simply the most piercing notes in that concert of the expensively
provisional into which your supreme sense of New York revolves itself. They
never begin to speak to you, in the manner of the builded majesties of the world as
we have heretofore known such - towers or temples or fortresses or palaces -
with the authority of things of permanence or even of things of long duration. One
story is good only till another is told, and sky-scrapers are the last word of
economic ingenuity only till another word be written ${ }^{352}$.

As suas partes desconectadas, ruas e prédios, não expressam o adensamento da história, ao contrário do que James vivencia nas cidades europeias. O ritmo frenético

${ }^{352}$ JAMES, Henry. The American scene, cit., p. 420. 
de desenvolvimento de Nova York é análogo ao ritmo da produção industrial e da novidade.

34) The leaden twilight weighs on the dry limbs of an old man walking towards Broadway. Round the Nedick's stand at the corner something clicks in his eyes. Broken doll in the ranks of varnished articulated dolls he plods up with drooping head into the seethe and throb into the furnace of beaded lettercut light. 'I remember when it was all meadows,' he grumbles to the little boy. ${ }^{353}$

Desse lugar que, no espaço de uma vida, deixou de ser uma região de pastos e poucas construções, não há rastros. Sabemos que esse senhor está na altura da rua 23 (esquina em que ficava a antiga e famosa lanchonete Nedick's) e que, até 1828, a avenida Broadway se estendia do sul da ilha até apenas a rua 10, ainda Lower Manhattan. Contudo, em 1860, já havia ruas sendo pavimentadas na altura da $155^{354}$. Esse senhor anônimo, boneco quebrado entre outros bonecos ágeis e articulados, também parece deslocado nessa cidade que se transformou ${ }^{355}$. Lendo relatos e reflexões da época, é possível perceber como havia um desinteresse pelo passado da cidade. No mesmo sentido da impressão de Ford Madox Ford, que observava, já na década de 1920 (e talvez com alguma carga de preconceito do turista inglês na nova colônia), "a ausência de história em Nova York" ${ }^{356}$, a revista Harper's Monthly, de 1856, lamentava a constante destruição da história física dessa metrópole:

Por que deveria ser amada como cidade? Nunca é a mesma cidade por mais de uma dúzia de anos. Um homem nascido em Nova York quarenta anos atrás não encontra nada, absolutamente nada, da Nova York que ele conhecia ${ }^{357}$.

No romance de Dos Passos, o percurso desse senhor em seu caminho para a Broadway é a experiência da dissociação entre a memória e a vivência do espaço um espaço constantemente transformado por essa máquina que, nebulosamente, quase se transfigura em uma força natural. Essa curiosa mistura de máquina e dinâmica natural gera o que Lowry descreveu, ao analisar o romance de Dos Passos, como uma

\footnotetext{
353 “O crepúsculo plúmbeo pesa nos membros secos de um velho caminhando em direção à Broadway. Virando a banquinha do Nedick's na esquina algo estala em seus olhos. Boneco quebrado entre fileiras de bonecos envernizados articulados ele se arrasta com a cabeça caída para o zunido e a vibração para a fornalha de letreiros luminosos. "Eu lembro quando era só mato", ele resmunga para o menino". [Tradução nossa].DOS PASSOS, John. Manhattan Transfer, cit., p. 211.

${ }^{354}$ HOMBERGER, Eric. The Age of "Go Ahead" 1825-1860. In: York city. New York: Henry Holt and Company, 2005, p. 79.

355 "New York's volume is a sign of its protean ability to assume new shapes and discard old ones; the city changes before your eyes. The physical and architectural upheavel of the city was a symbol of its inner spirit." DOUGLAS, Ann. Terrible honesty, cit., p. 17.

${ }^{356}$ DOUGLAS, Ann. Terrible honesty, cit., p. 10.

${ }^{357}$ BURROWS, Edwin. G.; WALLACE, Mike. Gotham, cit., p. xxii.
} 
separação contínua entre os artefatos e "o controle humano", conferindo aos primeiros uma "aura supersticiosa",358.

Com o desenvolvimento técnico, a própria cidade começa a ser vista e almejada como máquina. William James, em 1907, escreveu que a primeira impressão que se tinha ao chegar em Nova York era de repulsa. Uma vez "instalado", era possível sentir "o pulso da máquina, absorver o ritmo e vibrar com ele" ${ }^{359}$. De forma análoga, a ideia de eficiência e de controle do tempo e do espaço aparece na fala do então famoso historiador Charles Beard, para quem a cidade moderna, "um produto da era da máquina, deve ser estudada, controlada e taylorizada" ${ }^{„ 360}$. Ou seja, a identificação entre a lógica da produção industrial e a metrópole deveria ser reforçada, e os traços ineficientes, removidos como bonecos quebrados entre tantos bonecos novos.

Essa lógica da produção e do progresso, tal como se desenvolveu nos Estados Unidos, estava diretamente associada a um tipo específico de relação com o passado:

Em 1885, o economista americano David Wells parabenizara a indústria americana por sua habilidade de aceleração ao abandonar o obsoleto, por sua recusa em despender precioso capital e tempo num esforço para modernizar o passé; ao contrário de seus contemporâneos europeus, os americanos sabem que o máximo de eficência significa destruir, e não remodelar, equipamentos obsoletos $^{361}$.

Constantemente permeada pela ideologia do desenvolvimento, a ideia de oposição a outro sistema, que fosse um sistema agrário jeffersoniano, nem sequer se coloca. Como nota Myra Jehlen, a noção de "valores residuais" estava associada, nos Estados Unidos do fim do século XIX, ao Velho Mundo, o que explica a sua ampla rejeição. Para a autora, a ausência de um passado feudal ajuda a compreender essa maior permeabilidade frente à ideologia do progresso. A ideia de um "avanço tecnológico", desprovida de nostalgia, estava conectada à noção de desenvolvimento natural $^{362}$. O romance não apresenta valores residuais que se oponham ao progresso,

\footnotetext{
${ }^{358}$ LOWRY, E. D. Manhattan Transfer: Dos Passos' Wasteland. In: HOOK, Andres (Ed.). Dos Passos: a collection of critical essays. New Jersey: Prentice-Hall, Inc., 1974, p. 1.629.

359 JAMES, William apud OATS, Joyce Carol. Imaginary Cities: America. In: JAYE, Michael; WATTS, Ann Chalmers (Eds.). Literature and the urban experience. New Jersey: Rutgers University Press, 1976, p. 19.

${ }^{360}$ BEARD, Charles apud KORITZ, Amy. Urban Form vs. Human Function in the 1920s: Lewis Mumford and John Dos Passos. American Studies, v. 45, n. 2, p. 106, Summer 2004.

${ }^{361}$ DOUGLAS, Ann. Terrible honesty, cit., p. 186.

362 JEHLEN, Myra. The novel and the American middle class. In: BERCOVITCH, Sacvan; JEHLEN, Myre (Eds.). Ideology and classic American literature. Cambridge: Cambridge University Press, 1987, p. 128. Ver também HARVEY, David. How America's power grew. New imperialism. Nova York: Osford University Press, 2003.
} 
nenhuma nostalgia de um estado anterior capaz de suprir as necessidades não atendidas do presente. Não é à toa, portanto, que o campo não aparece como dicotomia: o ideal jeffersoniano de um país rural havia ficado em um passado que a grande metrópole comercial dos Estados Unidos, identificada imediatamente com a lógica da produção, precisava abandonar para a realização de sua tendência inerente como primeiro "país moderno" do mundo. Como disse Gertrude Stein:

America [is] the oldest country in the world because, by the methods civil war and the commercial conceptions that followed it, America created the twentieth century $^{363}$.

E, no século $X X$, o país que o criara seria também aquele que assumiria, no contexto mundial, as dimensões modernas de um império.

\subsection{Cidade imperial}

O segundo capítulo do romance, "Metropolis", abre com a notícia da consolidação da região de Nova York - a anexação à Manhattan do Brooklyn, Queens, Bronx e Staten Island. O tema da consolidação e do crescimento da metrópole são recorrentes durante o romance e fazem contraponto com os planos de ascensão econômica latente nas diferentes intrigas - Emile, por exemplo, acredita ingenuamente em uma Nova York que seria a terra das oportunidades para um homem comum como ele; também Thatcher idealiza o seu crescimento econômico e pessoal relacionando-o ao desenvolvimento da metrópole; o tio de Jimmy, Jeff Merivale, garante ao sobrinho incrédulo que o sucesso em Nova York representaria o sucesso em qualquer lugar do mundo.

Crescimento, progresso, sucesso: a epígrafe de abertura do capítulo já dá a dimensão do tema:

35) There were Babylon and Nineveh; they were built of brick. Athens was gold marble colums. Rome was held up on broad arches of rubble. In Constantinople the minarets flame like great candles round the Golden Horn... Steel, glass, tile, concrete will be the materials of the skyscrapers. Crammed on the narrow island the millionwindowed buildings will jut glittering, pyramid on pyramid like the white cloudhead above a thunderstorm $^{364}$.

\footnotetext{
${ }^{363}$ STEIN, Gertrude. The autobiography of Alice B. Toklas. In: VECHTEN, Carl Van. (Org.). Selected writings of Gertrude Stein. New York: The Modern Library, 1962, p. 73.

364 "Havia a Babilônia e Nínive; elas eram construídas de tijolos. Atenas era colunas de mármore douradas. Roma era sustentada por largos arcos de cascalho. Em Constantinopla, os minaretes queimavam como grandes velas em volta do Corno de Ouro... Aço, vidro, azulejo, concreto serão os materiais dos arranha-céus. Comprimidos na ilha estreita prédios de milijanelas vão se sobressair
} 
Como ocorre durante todo o romance, esse parágrafo de abertura é grafado em itálico. Nesse caso específico, o trecho introduz temas importantes para a obra como um todo e que vão reaparecer de maneiras diversas nas páginas subsequentes. A abertura dessa "epígrafe" sugere a recuperação de tempos imemoriais a partir da fórmula "there were...". A primeira frase faz jus à fórmula ao mencionar Babilônia e Nínive, essas duas antigas cidades de presença quase mítica no imaginário coletivo. Em seguida, são alinhavadas Roma, Constantinopla e Atenas. A enumeração acumulativa das cidades, seguida dos materiais que sustentam as suas arquiteturas, aparece em oposição à acumulação dos materiais de que são feitos os arranha-céus. Por fim, chega-se à ilha de Manhattan, com seus prédios com milhares de janelas, comparados às pirâmides.

O trecho estabelece uma relação, reiterada ao longo do romance, de comparação entre a metrópole moderna e cidades monumentais da história, principalmente aquelas que se tornaram, no imaginário ocidental, símbolos da decadência moral e física, como Sodoma, Babilônia e Nínive ${ }^{365}$. O recurso, que associa a cidade a esses antigos mitos, não é novo: já em 1846, no romance de Balzac La cousine Bette, por exemplo, encontramos uma alusão muito próxima à desenvolvida em Manhattan Transfer, também no que diz respeito a seu tom:

\begin{abstract}
No dia seguinte, ao meio dia, após uma suculenta refeição, Hulot vê entrar umas dessas obras-primas que, no mundo todo, só Paris pode fabricar graças ao incessante concubinato entre o luxo e a miséria, entre o vício e a honestidade, entre o desejo reprimido e a tentação renovada, que torna essa cidade herdeira de Nínive, de Babilônia e da Roma imperial ${ }^{366}$.
\end{abstract}

O narrador de Balzac se vale da mitologia que envolve a imagem das cidades históricas de Roma, Babilônia e Nínive para estabelecer uma relação alegórica com a Paris do século XIX. Segundo Robert Alter, mais próximo de um “mitógrafo de Paris" do que de uma testemunha realista, Balzac emprega o imaginário invocado por esses grandes mitos para expressar a intensidade dessa experiência, a "conjunção de

brilhando, pirâmide sobre pirâmide como mais alta nuvem branca sobre uma tempestade." [Tradução nossa.] DOS PASSOS, John. Manhattan Transfer, cit., p. 3.

${ }^{365}$ VANDERWERKEN, David L. Manhattan Transfer: Dos Passos' Babel Story. American Literature, v. 49, n. 2, p. 253, May 1977.

${ }^{366}$ Tradução nossa do original: "Le lendemain à midi, après un succulent déjeuner, Hulot vit entrer un de ces vivants chefs-d'œuvre que Paris, seul au monde, peut fabriquer à cause de l'incessant concubinage du Luxe et de la Misère, du Vice et de l'Honnêteté, du Désir réprimé et de la Tentation renaissante, qui rend cette ville l'héritière des Ninive, des Babylone et de la Rome impériale" BALZAC, Honoré de. La cousine Bette. Paris: Garnier Frères, 1962, p. 92. 
extremos" que parecia dominar a cidade ${ }^{367}$. A comparação entre Paris e as grandes capitais da história foi comum durante todo o século XIX. Além de enfatizar a sua magnitude, a evocação também se revestia de traços apocalípticos, alçando a capital francesa à esfera das grandes cidades míticas.

Era moda entre as nações estrangeiras, depois dos desastres de 1871, clamar contra a corrupção da "Babilônia moderna" e ver um castigo em nossas derrotas. Retórica e lugares-comuns que não têm nem mesmo o mérito da novidade. ${ }^{368}$.

O que pode ter tido início com uma advertência em relação aos perigos do vício a que o habitante da Paris do século XIX estava exposto (Roger Callois supõe que a associação à Babilônia tenha surgido nos sermões religiosos ${ }^{369}$ ), funda uma mitologia urbana. Essa mitologia se constrói em torno da mistura de opulência e decadência que reforça o aspecto ininteligível de um espaço que parece resistir a ser apropriado na sua totalidade ${ }^{370}$. Essa associação tornou-se um procedimento corriqueiro e ressurge mesmo na obra de um escritor tão pouco afeito aos grandiosos arrebatamentos balzaquianos quanto Henry James. Em The ambassadors, Paris também aparece como uma "Babilônia vasta e brilhante, como um objeto enorme e iridescente" 371 .

Quase um século depois de Balzac, o romance modernista de Alfred Döblin recuperará a cidade da Babilônia como alegoria, ou seja, como citação literal e também moral para a complexa construção de Berlin Alexanderplatz. Ali, a associação entre a metrópole alemã e a Babilônia serve principalmente para a construção de um imaginário apocalíptico que funciona para contrapor-se aos elementos mais pedestres do romance e complementá-los. Entre as duas esferas, equilibra-se Biberkopf. Mais próximo de Dos Passos, também no romance Sister

\footnotetext{
${ }^{367}$ ALTER, Robert. Imagined cities, cit., p. 7.

${ }^{368}$ Tradução nossa do original: "Ç’a été la mode parmi les nations étrangères, après les désastres de 1871 , de crier à la corruption de la "Babylone moderne" et de voir un châtiment dans nos défaites. Rhétorique et lieux communs qui n'ont même pas le mérite de la nouveauté”. DU CAMP, Maxime. Paris, ses organes, ses fonctions et sa vie dans la seconde moitié du XIXe siècle. Paris: Hachette, 1875, p. 288.

${ }^{369}$ CAILLOIS, Roger. The edge of surrealism: a Roger Caillois reader. Durham: Duke University Press, 2003, p. 178.

${ }^{370}$ Nesse sentido, é interessante relembrar os termos utilizados por Dos Passos para expressar a sua primeira impressão quando desembarca, em 1922, em Nova York. Ao recordar, durante uma entrevista, o que o levara a escrever sobre essa metrópole, o autor afirma: "It was marvelous. It was hideous. It had to be described". DOS PASSOS, John. What Makes a Novelist (1968), cit., p. 271. Essa mistura de horror e beleza nos remete justamente à noção de sublime como algo cuja totalidade foge à compreensão imediata do espectador.

${ }^{371}$ JAMES, Henry. The ambassadors. New York: Oxford University Press, 1998, p. 63.
} 
Carrie há uma alusão, de forma indireta, à Babilônia: o título do Capítulo XXXII faz referência a Baltazar, o último rei antes da destruição da cidade corrompida ${ }^{372}$.

Em diálogo intencional com essa tradição de alegorizar a metrópole, John Dos Passos menciona as mesmas referências de Balzac ${ }^{373}$, mas reforça, por seu turno, o caráter material de cada uma delas: "they were built of brick" 374 . Aqui não temos a "Babilônia prostituta" de Berlim ou Nínive como sinônimo da "concubinagem incessante de luxo e miséria" e correlato de Paris. A construção desse breve parágrafo, em vez de sublinhar aspectos morais, demora-se sobre a engenharia dessas cidades e enfatiza a sua dimensão material, construída pelo homem. No texto de Balzac, como em outros romances do século XIX, predomina o sentido moralista da aproximação: Paris vive uma tensão com as forças latentes do vício, do luxo e do desejo reprimido $^{375}$. Esse aspecto moralista, problematizado em Döblin, está praticamente ausente nessa passagem do romance de Dos Passos, pois, embora a simples menção desses ícones já sobreponha ao texto as significações historicamente acumuladas, a descrição procura reforçar, pela referência aos materiais das construções arquitetônicas, a perspectiva histórica - são cidades cujos materiais representam diferentes estágios do desenvolvimento das forças produtivas. O narrador está, no plano mais imediato, falando do progresso técnico. Sem dúvida, a simples referência a essas cidades já carrega consigo a visão do passado como ruínas; contudo, o foco nos aspectos arquitetônicos dessas grandes capitais tem duplo sentido. Por um lado,

\footnotetext{
372 "O banquete de Belsazar: um profeta para traduzir.” DREISER, Theodore. Sister Carrie, cit., p. 325.

${ }^{373}$ Como já se disse, eram comuns durante todo o século XIX. Por exemplo, neste texto de Du Camp: "Quel que soit le sort qui attende Paris lorsque les âges lointains et mystérieux auront clos ses destinées, qu'il soit, comme la Thèves aux cent portes, couché le long de son fleuve, jonchant la terre de ses immenses ossements; qu'il soit comme Ninive, comme Babylone, une énigme archéologique proposée à la sagacité des savants futurs; qu'il soit comme Athènes, un fantôme d'une grâce incomparablement touchant; qu'il ait comme Rome des fortunes successives et adverses; que comme Constantinople il voie dormir un peuple de barbares ignorants; qu'il meure demain, qu'il meure dans vingt siècles; qu'il s'éteigne dans sa propre indolence, qu'il continue sa vie de crimes, de hauts faits, de vices et de vertus, qu'importe!" [Grifos nossos.] DU CAMP, Maxime. Paris, ses organes, ses fonctions et sa vie dans la seconde moitié du XIXe siècle, cit., p. 392.

${ }^{374}$ Essas associações já aparecem nas cartas de Dos Passos, quando ele volta para Nova York em 1920: "Still New York is amusing. It has its hanging gardens of Babylon aspect". DOS PASSOS, John. The fourteenth chronicle..., cit., p. 303.

375 "Summarising nineteenth-century images of Babylon and Jerusalem, John Short sees them a describing different perceptions of rural and urban. The city as Babylon was part of a worldview wich celebrated the order, harmony and sheltered existence of rural life, which the city rudely disrupted. The city as Jerusalem rescued us from te idiocy and the stultifying repression of rural life. But by the early twentieth-century, these polarities were less secure. The modern city was increasingly to be seen as simultaneously Babylon and Jerusalem." DENNIS, Richard. Cities in modernity. Representation and productions of metropolitan space, 1840-1930. New York: Cambridge University Press, 2008, p. 51. Cabe se perguntar, contudo, se a sumarização inicial faz jus, por exemplo, a uma obra como a de Balzac.
} 
evidencia a identidade entre todas as cidades do passado e as que estão sendo erigidas: Atenas, Constantinopla, Roma, Babilônia e Nínive, grandes construções humanas que, em determinado momento, foram destruídas. Por outro, a sugestão do desenvolvimento técnico encena uma concepção teleológica e positiva do desenvolvimento histórico: as metrópoles dos arranha-céus não são de cascalho, mármore ou tijolo, mas de aço, vidro e concreto - materiais modernos e resistentes com os quais, empilhando uma pirâmide sobre a outra, poderão finalmente erguer-se sobre a tempestade. 


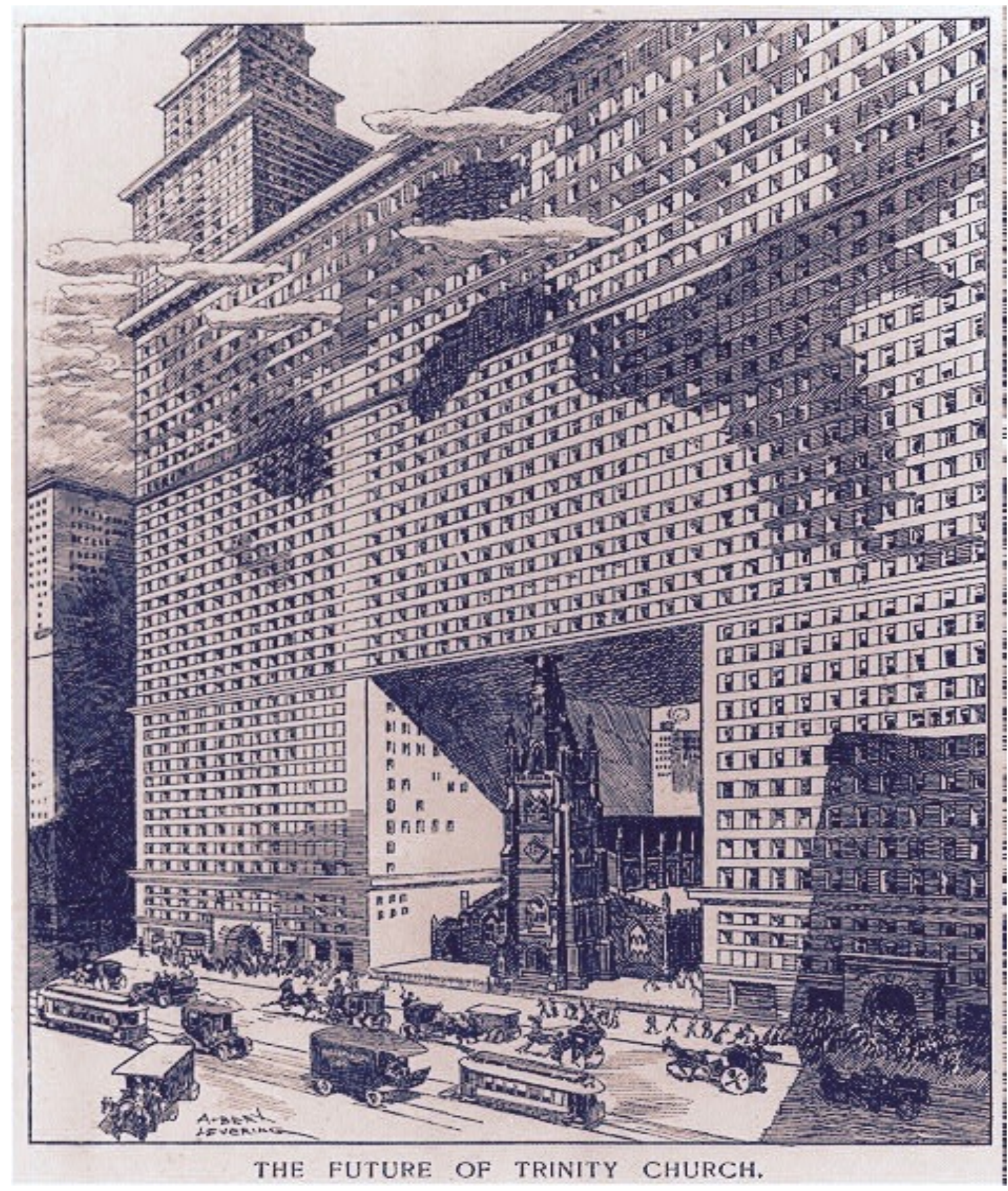

Figura 9 - O Futuro da Igreja da Trindade [The Future of Trinity Church], 1907. Imagem retirada do website da Library of Congress ${ }^{376}$.

Ao que tudo indica, há na superfície do texto um otimismo que faz parte da ideologia que define e qualifica a cidade: Nova York está acima das tempestades. A ilustração reproduzida acima (Figura 9), publicada em 1907, expressa os projetos imaginários, então na ordem do dia, para a metrópole. Feita por Albert Levering para

\footnotetext{
${ }^{376}$ Disponível em: <https://www.loc.gov/item/2005694696>. Acesso em: 17 abr. 2017.
} 
a revista satírica Puck, a imagem retrata a igreja Trinity (a edificação mais alta de Nova York até 1890) devorada por uma construção gigantesca, sobretudo para os padrões da época, que termina acima das nuvens. Principalmente na virada do século, a metrópole portuária parecia capaz de superar qualquer tentativa ou estágio anterior de desenvolvimento urbano e técnico.

$\mathrm{Na}$ virada do século, o desenvolvimento técnico já havia se espalhado pelo país e os seus sinais já se faziam presentes mesmo em regiões distantes das grandes capitais, por meio da transformação da paisagem e da implementação das redes de esgoto, luz, gás e telefone. A máquina se torna cada vez mais presente também na paisagem rural e no imaginário coletivo - o que não se deu, é claro, de forma "natural". Como mostra Cecelia Tichi, houve um grande esforço editorial para difundir a toda população noções e terminologias associadas à tecnologia mais avançada. As inúmeras revistas voltadas para o público leitor de classe média enfatizavam continuamente a tendência do país ao avanço tecnológico, que já seria muito superior, na época, ao de qualquer outra nação. A difusão dessa ideologia e da terminologia do desenvolvimento técnico abandonava os espaços do trabalho para se tornar presente inclusive no cotidiano doméstico. Tichi explora uma série de obras da literatura popular da época para mostrar de que modo o vocabulário e imagens associados a máquinas ou às novas invenções tecnológicas permeavam a narrativa mesmo em livros cujo tema não era a tecnologia em $\mathrm{si}^{377}$. A autora demonstra também como os meios de comunicação assumiram o papel de difundir princípios associados ao desenvolvimento técnico, de forma que a Harper's Weekly, uma revista de grande circulação publicada em Nova York, anunciou em 1912 que as mudanças em curso em toda a nação eram monumentais e que, com o avanço do "movimento em direção à maior eficiência, começou uma nova era, mais aperfeiçoada, da vida nacional"378.

A crença na potência desse progresso e no papel a ser cumprido pelos Estados Unidos, a "primeira nação moderna do mundo", ajuda a entender melhor o significado dessas associações estabelecidas na epígrafe e dessa cidade capaz de se erguer acima das tempestades.

Os americanos nos anos 1920 gostavam do termo "América" principalmente por suas sugestões imperiais de uma identidade intoxicante e irresistível formada pela força do destino: essa geração tinha pouco motivo para antecipar as lições mais duras da história ${ }^{379}$.

\footnotetext{
${ }^{377}$ Ver TICHI, Cecelia. Shifting gears, cit., p. 17-40.

${ }^{378}$ Apud TICHI, Cecelia. Shifting gears, cit., p. 75.

${ }^{379}$ DOUGLAS, Ann. Terrible honesty, cit., p. 03.
} 
Nacional e estrangeira, Nova York já era chamada, por volta dos anos 1820, de Empire City, quando a construção do Canal do Eire foi concluída. Com o novo canal, o porto de Nova York podia se comunicar com o interior do país e, assim, assegurar liderança mercantil em relação aos portos rivais, o que fomentou uma transformação da cidade e o aumento rápido do comércio, dos setores de manufatura e dos investimentos ${ }^{380}$. "Império" (que se tornou nome de tantas agências e empreendimentos na metrópole), como comentou Dennis Richard, designava não apenas a liderança econômica mas também a autoridade moral e ideológica que a cidade pretendia assumir ${ }^{381}$. Na época em que o pequeno entreposto comercial foi alçado à categoria imperial, os Estados Unidos passavam por um embate ideológico acerca do papel que deveriam assumir em relação às outras nações. No período jacksoniano (1829-1837), o "Destino Manifesto" se torna a justificativa para um projeto imperialista que se opunha frontalmente ao modelo jeffersoniano de democracia. Quando, em 1836, o artista Thomas Cole realizou a exposição pública de uma série monumental de pinturas suas denominada The Course of Empire, a sua narrativa plástica sobre a decadência da fictícia cidade imperial representada em seus quadros tinha por objetivo servir como alerta contra os esforços internacionais do país. Cole, um jeffersoniano, propunha uma reflexão sobre a ambição imperialista que parecia, ao artista, contrária aos ideais fundamentais da nação. O ponto mais curioso é o de que a recepção da obra de Cole, aparentemente, foi oposta à que seu autor esperava. A produção, muito elogiada, foi interpretada como uma exposição sobre o curso da "maioria" dos impérios: a regra da qual os Estados Unidos mostraria ser a grande exceção. A anedota é interessante porque ilumina uma tensão presente na passagem que vínhamos analisando. Por um lado, a menção de Babilônia, Nínive e Roma nos aparece, imediatamente, como signo da decadência e da ruína - o que, sem dúvida, está presente nesse trecho. Contudo, é importante pensar que a ideologia

\footnotetext{
${ }^{380}$ Ver BURROWS, Edwin. G.; WALLACE, Mike. Gotham, cit., p. 429-451.

381 "The 'American Empire' is a more contentious and mostly late twentieth-century concept, but New York was known as the 'Empire City' from at least the 1820 s and by the mid-nineteenth century, 'empire' was used in the names of many New York businesses and institutions. As David Scobey notes, the word was used to invoke not only mercantile power but also moral and political leadership. 'Empire' rarely carried any negative connotations of unjustified expansionism; an emperial New York not only conferred the blessings of cultural and economic progress on its citzens but also spread civilisation to thoso with whom it communicated." DENNIS, Richard. Cities in modernity, cit., p. 26.
} 
nacional do império fazia com que o país se enxergasse como um caso de exceção na história das ruínas.

Durante o século XIX, preservar essa posição não foi simples. A consolidação da "Grande Nova York", que ocorreu em 1896 e sobre a qual falamos no segundo capítulo, é uma resposta à tentativa de assegurar à metrópole o papel que esta precisava representar para garantir o seu desenvolvimento econômico. Entre $1880 \mathrm{e}$ 1890, portos rivais começaram a crescer em importância, aproveitando as dificuldades de modernização e expansão do complexo portuário de Manhattan. As dificuldades deviam-se ao fato de diferentes jurisdições políticas (já que cidades diferentes compartilhavam o mesmo sistema fluvial) precisarem se coordenar para que qualquer medida fosse colocada em prática ${ }^{382}$. Nessa época, a competição dos portos de Nova Orleans, Boston e Filadélfia e o crescimento populacional de Chicago pareciam colocar em risco o "destino imperial" de Nova York "como a maior cidade do mundo" 383 . A solução para esse problema foi a consolidação da metrópole a partir da reunião de Brooklyn, Queens, Staten Island, Bronx e Manhattan. Com isso, Nova York assegurou a sua posição, aumentando imediatamente a sua população, tornandose a segunda maior cidade do mundo e realizando melhorias para uma ampliação significativa de sua infraestrutura. Com o fortalecimento de seu porto e o "crescimento" populacional, a cidade foi capaz de dar conta dos dois fatores que pareciam colocar em risco o papel que a cidade pretendia ter nos novos tempos.

Na virada do século XX, a expansão territorial dos Estados Unidos já havia desacelerado. Os seus limites geográficos estavam praticamente estabelecidos, e os projetos públicos de expansão da fronteira oeste já estavam concluídos. Quando Dos Passos escreveu o seu romance na década de 1920, o termo imperialismo não significava mais, necessariamente, a conquista de territórios, mas, antes, a "colonização do futuro" por meio da criação, do monopólio e da "venda a taxas vertiginosas do próprio processo de modernização"384. Enquanto as grandes nações

\footnotetext{
${ }^{382}$ BURROWS, Edwin. G.; WALLACE, Mike. Gotham, cit., p. 1.223.

${ }^{383}$ Citação da proposta do prefeito Hewitt para uma série de melhorias na estrutura portuária da cidade. Apud BURROWS, Edwin. G.; WALLACE, Mike. Gotham, cit., p. 1.223.

${ }^{384}$ DOUGLAS, Ann. Terrible honesty, cit., p. 185. Vale notar, contudo, que durante o período em que se passa o romance, ou seja, na virada do século, os Estados Unidos demonstraram um ímpeto colonizador bastante agressivo: em 1989, "ao declarar e vencer a Guerra Hispano-Americana e conquistar - pelo Tratado de Paris de 1898 - Cuba, Guam, Porto Rico e Filipinas, começando uma escalada colonial que prosseguiu com a intervenção no Haiti em 1902, no Panamá em 1903, na República Dominicana em 1905, em Cuba, novamente em 1906 e, de novo, no Haiti em 1912”. Contudo, "entre 1900 e 1914, o governo americano foi obrigado a definir sua política frente a estes
} 
europeias acabaram comprometidas com os gastos da guerra no início do século, o que as impossibilitou de modernizar as suas indústrias, nos Estados Unidos as transformações das produções industrial e cultural foram instauradas em ritmo acelerado - também como resposta às necessidades da guerra no continente europeu. Como confessou o grande magnata das salas de cinema de Nova York, Marcus Loew, "métodos de lojas em cadeia nos cinemas são como o que temos em ferrovias, telefones e automóveis" ${ }^{385}$. Esse desenvolvimento das técnicas de produção industrial, das mídias e do entretenimento fizeram com que o país se tornasse ele mesmo um “sinônimo de aceleração",386.

Por isso, quando Dos Passos elabora aquela epígrafe, discutida algumas páginas antes, para comparar Nova York às grandes capitais imperiais da história, são principalmente as noções de império e de técnica que estão em jogo. E essa tensão presente na cena será desdobrada de diversas formas ao longo do romance. Enquanto evidencia a crença socialmente disseminada na excepcionalidade estadunidense (nesse caso, Nova York como o grande símbolo do novo país), mantém também como potencial latente, tensionando a superfície, uma vertigem da ruína, ao mesmo tempo, como história e presságio.

História e presságio porque, no decorrer do romance, essa positividade que recobre a superfície do texto, evidenciada na relação estabelecida com as diferentes eras da história, será problematizada - embora não seja inteiramente negada, uma vez que a cidade permanece em pé até o fim do romance. Entretanto, o otimismo em relação à realização das promessas do desenvolvimento técnico será contestado. Um dos aspectos interessantes do livro reside justamente nessa sobreposição: por um lado, o texto explicita o discurso da crença otimista da promessa do progresso ("cloudhead above a thunderstorm"), por outro, associa esse processo aos fracassos do passado. Apesar de sugerir, na superfície do discurso, que a força do aço e do vidro podem ser capazes de superar as ruínas do passado, o próprio desenvolvimento do texto, o desenrolar das tramas e o princípio da montagem colocarão esse otimismo em xeque.

Há ainda outro desdobramento importante desvelado pela equação entre Nova York e a ideia de império: assim como em sua origem no século XIX, a questão

novos territórios conquistados além-mar e optou por um novo tipo de controle político, na forma de protetorados militares e financeiros, dos Estados Unidos, como foi o caso da República Dominicana, Haiti, Nicarágua, Panamá e Cuba”. FIORI, José Luís. O poder global dos Estados Unidos: formação, expansão e limites. In: FIORI, José Luís (Ed.). O poder americano. Petrópolis: Vozes, 2004, p. 77-78.

${ }_{385}$ Apud DOUGLAS, Ann. Terrible honesty, cit., p. 189.

${ }^{386}$ DOUGLAS, Ann. Terrible honesty, cit., p. 191. 
estava associada ao papel que os Estados Unidos cumpriam nas Guerras de Independência de outros países e na subsequente anexação de territórios. Quando Dos Passos retoma esse tema no século XX em Manhattan Transfer, está em jogo a participação do país na Primeira Guerra Mundial (que comparece de forma oblíqua, mas sempre latente) e suas consequências políticas e econômicas. Dos Passos possui uma série de textos escritos pouco antes da decisão de Woodrow Wilson (em abril de 1917), criticando uma possível participação estadunidense na guerra. Para poder ver como era o campo de batalha sem, contudo, "servir às potências" ${ }^{387}$ responsáveis pela guerra que ele tanto desprezava, Dos Passos se alistou como motorista de ambulância voluntário. Esse período que passou na Europa nada fez para contrariar as convicções antibelicistas do jovem Dos $\operatorname{Passos}^{388}$. Pelo contrário, as suas posições pacifistas se confirmaram e a guerra the parecia, mais do que nunca, "uma completa bobagem”,389 dirigida pelos interesses daqueles que nunca pisariam no campo de batalha. Os seus dois primeiros romances, One man's initiation - 1917 e Three soldiers, comentados no primeiro capítulo, dão testemunho das reflexões que tal experiência insuflou no autor. Portanto, recuperar essa noção da cidade imperial, recolocando a tensão entre a história como ruína e os Estados Unidos como exceção é um dos pontos mais interessantes do texto, pois estabelece um confronto direto com a política que o país parecia ter em vista a partir da participação na Primeira Guerra - e à qual Dos Passos se opunha frontalmente.

Quando os Estados Unidos despontaram vencedores da Primeira Guerra Mundial, momento em que havia o reconhecimento e a valorização de aspectos do desenvolvimento de sua cultura nacional, essa tendência imperialista começou a ganhar impulso e tornar-se uma perspectiva real. Se os Estados Unidos já haviam se tornado um poder hegemônico no continente e desempenhavam uma posição ativa na região asiática após a dominação das Filipinas, quando entraram na Primeira Guerra Mundial, o que estava em questão era uma "luta pela hegemonia dentro da Europa

\footnotetext{
${ }^{387}$ MORRIS, James McGrath. The ambulance drivers. Hemingway and Dos Passos, a friendship made and lost in war. New York: Da Capo Press, 2017, [s/p].

${ }^{388}$ Após a primeira Grande Guerra, Dos Passos sustentou uma forte crítica ao papel que os Estados Unidos haviam assumido: "From the loved refuge from oppression in how few years have we become for all the world one of the most hated militarist nations". DOS PASSOS, John. America and the Pursuit of Happiness (1920). In: PIZER, Donald (Org.). John Dos Passos: the major nonfictional prose. Detroit: Wayne State University Press, 1988, p. 55.

${ }^{389}$ DOS PASSOS, John. Letter to Rumsey Marvin (Aug. 1917). In: cit, p. 92. 
onde existiam ainda contradições e resistências objetivas" à inserção do poder político e econômico estadunidense ${ }^{390}$. Embora o resultado objetivo dos seus esforços de hegemonia econômica, militar e política só tenham se realizado plenamente com a Segunda Guerra Mundial, o fim da Primeira Guerra é marcado pela transformação da posição econômica dos Estados Unidos no cenário mundial ${ }^{391}$.

No romance de 1925, a Primeira Guerra aparece tangencialmente, por meio de falas das personagens que reformulam aquilo que os jornais anunciam: "what gives me gooseflesh is the armies mobilizing, Belgrade bombarded, Belgium invaded"392. A guerra serve, por um lado, para situar cronologicamente o leitor e, nessa medida, é como mais um ready-made do cotidiano que ancora as intrigas em um solo histórico reconhecível. Dessa forma, ela é apenas mais uma referência que não afeta em nada o andamento da metrópole, aparentemente imune aos grandes abalos sísmicos de seu tempo - o que deveria, como já dissemos, corresponder à experiência de boa parte da população para quem a Guerra, do outro lado do Atlântico, parecia uma notícia terrível, mas sem relevância objetiva no dia a dia. Por outro lado, na última parte do romance, ela aparece como uma memória quase bucólica para Jimmy, que o leitor percebe como uma lembrança distorcida pelo tempo e pela distância; afinal, a mulher que aparece em seus recordações idílicas não possui nenhum traço similar à Ellen que o leitor acompanhou desde o começo do romance. A guerra aparece, então, como uma espécie de miragem recontada a partir da perspectiva de cada uma das personagens, pois, embora o período faça parte da janela temporal do romance, os anos em que os Estados Unidos entram no campo de batalha, vale relembrar, não são retratados.

O fato de a Primeira Guerra não ser longamente discutida ou representada no romance, contudo, não a suprime da narrativa. Para Dos Passos, havia uma relação intrínseca entre as forças que promoviam a guerra, a forma que o combate tomou e o desenvolvimento industrial do capitalismo:

Na primeira Grande Guerra, o potencial tecnológico e econômico desenvolvido a partir da $2^{\text {a }}$ Revolução Industrial foi colocado a serviço dos combatentes no campo de batalha. Esta circunstância representou um salto no poder destrutivo dos armamentos e uma ampliação nas vantagens competitivas da indústria norteamericanas que, desde o final do século dezenove vinha liderando, juntamente

\footnotetext{
${ }^{390}$ FIORI, José Luís. O poder global dos Estados Unidos..., cit., p. 80.

391 "American merchants did not need colonies or wars of conquest if they could just have free access to markets. This idea of an "open door" became the dominant theme of American foreign policy in the twentieth century. It was a more sophisticated approach to imperialism than the traditional empirebuilding of Europe." ZINN, Howard. A people's history of the United States, cit., p. 301.

392 "O que me dá arrepios é o exército se mobilizando, Belgrado bombardeada, Bélgica invadida". [Tradução nossa]. DOS PASSOS, John. Manhattan Transfer, cit., p. 188-189.
} 
com a Alemanha, as inovações nos setores químicos, metalúrgico, metalmecânico e transportes ${ }^{393}$.

Nessa rede de inter-relações, ao tratar da industrialização, Dos Passos optou, em Manhattan Transfer, por selecionar não sua lógica em operação no tempo em suspenso da guerra - como fizera em seus dois primeiros romances -, mas, sim, em sua marcha cotidiana. O seu foco é compreender por meio da forma literária de que maneira a lógica industrial - responsável por abastecer e impulsionar as rodas da guerra em 1914 - prolonga-se no cotidiano em um espaço como Nova York.

\subsection{Uma máquina de guerra}

Um dos eventos mais importantes que ocorreram no período em que transcorre o romance foi a criação e a propagação do modelo produtivo do fordismo. É importante destacar o papel do fordismo ao falar sobre a lógica industrial e a sua colonização das relações sociais porque, conforme mostrou David Harvey, isso implicava mais do que uma "racionalização" por meio do gerenciamento e da segmentação do tempo na linha de produção, como havia sido proposto no taylorismo.

O método desenvolvido por Frederick Taylor, filho de uma família com raízes Quaker e puritana da Nova Inglaterra, foi implementado pela primeira vez entre 1897 e 1898. Após três anos de estudos e modificação, "140 homens estavam realizando as tarefas anteriormente feitas por 600,394 , e os resultados foram divulgados em artigos e livros entre 1900 e 1911. Taylor, que nunca abordou em seus escritos o problema do “desemprego gerado por seus sistemas"395, foi bastante criticado na época e seu método enfrentou ampla resistência por parte dos trabalhadores organizados. Ainda assim, a noção de eficiência pela racionalização da produção e aumento de ganhos era tentadora. A difusão e a discussão de seus textos extrapolaram a esfera industrial e houve uma disseminação por toda a sociedade de alguns valores novos, principalmente do termo "eficiência", aceito a partir de então como um valor praticamente universal mesmo pelos críticos do taylorismo ${ }^{396}$. Ford realizou um

\footnotetext{
${ }^{393}$ TAVARES, Maria Conceição; BELLUZO, Luiz Gonzaga. A mundialização do capital e a expansão do poder americano. In: FIORI, José Luís (Ed.). O poder americano, cit., p. 119.

${ }^{394}$ TICHI, Cecelia. Shifting gears, cit., p. 78.

${ }^{395}$ TICHI, Cecelia. Shifting gears, cit., p. 78.

${ }^{396}$ Para uma análise muito interessante sobre todo o processo de difusão da noção de eficiência a partir dos textos de Taylor, ver TICHI, Cecelia. Shifting gears, cit., p. 75-96.
} 
avanço técnico em relação a Taylor com a implementação "eficiente" da esteira rolante, a elevação dos salários (já prevista por aquele) e a produção de todos os componentes do produto final na mesma fábrica. Contudo, o que particulariza sua concepção é o fato de ela almejar a fabricação de uma verdadeira economia da vida social. A criação do novo operário, em uma organização que permitia horas de lazer e que garantia poder de compra, resultaria em uma regulação econômica de longo prazo. Segundo Gramsci:

Visto que existiam estas condições preliminares, garantidas pelo desenvolvimento histórico, foi relativamente fácil racionalizar a produção e o trabalho, combinando habilmente a força - a destruição do sindicalismo operário de alcance nacional com a persuasão - altos salários, benefícios sociais diversos, propaganda ideológica e política muito hábil -, conseguindo-se, assim, basear toda a vida do país sobre a produção ${ }^{397}$.

Além de regular o tempo de trabalho no interior da fábrica, Ford chegou a colocar em prática, por determinado período no ano de 1917, um programa em que uma equipe específica examinava a vida doméstica de seus empregados com o objetivo de avaliar se no campo privado e familiar esses funcionários correspondiam àquilo que se esperava deles: exigia-se e criava-se um "padrão de trabalho e lazer"398. Em $O$ grande capital, Dos Passos destaca a relação estabelecida entre o projeto industrial e o projeto de sociedade em uma passagem longa, mas profundamente iluminadora:

Eficiência era a palavra de ordem. A mesma engenhosidade que entrava na melhoria do desempenho de uma máquina podia entrar na melhoria do desempenho dos operários que produziam a máquina. (...)

operários bem remunerados podiam economizar dinheiro suficiente para comprar um Ford Bigode; no primeiro dia em que Ford anunciou que operários americanos de cabelo cortado e devidamente casados em busca de emprego tinham uma oportunidade de faturar cinco dólares por dia (é claro que havia certas condições; sempre havia certas condições) Park juntou-se uma multidão tão grande do lado de fora da fábrica de High and

durante toda uma noite de janeiro a zero grau

que houve tumulto quando os portões se abriram (...)

O Plano Americano; prosperidade automotiva vazando de cima para baixo; só que havia certas condições.

Mas aqueles cinco dólares por dia

pagos a operários americanos bons e limpos

que não bebiam nem fumavam cigarros nem liam nem pensavam,

e que não cometiam adultério

e cujas esposas não recebiam pensionistas,

fizeram mais uma vez da América o Yukon dos suados operários do mundo;

fizeram todos os Fords Bigode e a era automobilística, e incidentalmente

\footnotetext{
${ }^{397}$ GRAMSCI, Antonio. Americanismo e fordismo. São Paulo: Hedra, 2008, p. 38.

${ }^{398}$ DENNING, Michael. The cultural front: the laboring of American culture in the twentieth century. New York: Verso, 1998, p. 27.
} 
fizeram de Henry Ford, o homem do automóvel, o admirador de Edison, o amante de pássaros,

o grande americano de sua época ${ }^{399}$.

O controle da "moralidade", como observa Gramsci, mais do que um sintoma do puritanismo latente, era um projeto de controle produtivo: um trabalhador casado teria menos tendências ao alcoolismo e à vida desregrada, o que asseguraria um compromisso e uma assiduidade maiores com a fábrica. Como enfatiza Gramsci, o projeto era não só criar um novo "trabalhador" mas também um novo "homem"400. Além disso, a decorrente desqualificação do trabalho nas esteiras de produção permitiu a empregabilidade de uma legião de mão de obra sem preparo. É importante notar como essa estrutura foi alimentada pela multidão de imigrantes, pois havia uma grande resistência por parte dos trabalhadores estadunidenses e dos sindicatos ${ }^{401}$. Esses homens que, de outra forma, poderiam organizar-se, eram assimilados no novo ritmo fabril em um sistema, por um lado mecanizado, que lhe retirava a propriedade de trabalhador, e por outro o integrava à massa de consumidores, fazendo com que a sua identificação não se desse mais, necessariamente, em relação à classe operária. A alta rotatividade de trabalhadores, a desqualificação do serviço de base e a alta qualificação de um pequeno grupo responsável pela construção e manutenção do maquinário gerava uma ruptura interna na organização dos operários. A conversão da "classe trabalhadora em uma massa de trabalhadores" 402 mostrou-se uma forma de desorganizar as possíveis mobilizações, realizando um verdadeiro gerenciamento do conjunto da sociedade.

As implementações nas fábricas tiveram tamanho sucesso em termos quantitativos que o "modelo de organização das empresas Ford se impôs aos demais concorrentes" 403 . A implementação desse projeto em larga escala permitiu que, sem ser necessário aumentar o número de trabalhadores, a produção industrial do país dobrasse nos anos logo após a Primeira Guerra Mundial ${ }^{404}$. No mesmo capítulo de $O$ grande capital, citado anteriormente, Dos Passos explicita essa relação:

Quando a guerra estourou na Europa, tinha suas ideias também sobre isso. (A desconfiança em relação ao pessoal do exército e à profissão de soldado fazia

\footnotetext{
${ }^{399}$ DOS PASSOS, John. O grande capital. São Paulo: Benvirá, 2012, p. 70-71.

${ }^{400}$ GRAMSCI, Antonio. Americanismo e fordismo, cit., p. 66.

${ }^{401}$ HARVEY, David. Condição pós-moderna. Uma pesquisa sobre as origens da mudança cultural. São Paulo: Loyola, 1992, p. 123.

${ }^{402}$ DE MARIA, Fábio. Estado e classes sociais. Crítica da autoridade: Max Horkheimer e a primeira fase da teoria crítica, 2017. (Tese de Doutorado). São Paulo: Universidade de São Paulo, 2017. . p. 15.

${ }^{403}$ DE MARIA, Fábio. Estado e classes sociais. p. 20.

${ }^{404}$ DOUGLAS, Ann. Terrible honesty, cit., p. 187.
} 
parte da tradição rural do Meio-Oeste, como a poupança, a perseverança e a perspicácia em questões de dinheiro). Qualquer mecânico americano inteligente via logo que, se os europeus não fossem um bando de estrangeiros ignorantes e mal pagos que bebiam, fumava, tinham moral frouxa com as mulheres e eram relaxados nos hábitos de produção, talvez jamais tivesse havido guerra. (...) sociais,

Contratou um vapor, o Oscar II, e encheu-o de pacifistas e assistentes

para ir lá explicar aos principescos da Europa

que o que estavam fazendo era ruim e tolo. (...)

Dois anos depois Ford estava fabricando munições, lanchas Eagle, Henry Ford planejava tanques individuais e submarinos individuais. ${ }^{405}$

É nesse âmbito cotidiano que Dos Passos procura mapear e tornar visíveis as forças que, se operam de forma evidente na guerra, nem por isso constituem um momento de exceção. Pelo contrário, a guerra seria apenas um desdobramento alternativo de uma mesma lógica em operação no dia a dia da vida comum. Assim, o tempo que constrói essa cidade literária é análogo ao tempo industrial, bruscamente segmentado em partes que não diferem qualitativamente umas das outras e se repõem consecutivamente. Os esquetes das personagens aparecem, nesse sentido, como peças dessa máquina ou como os operários na linha de produção: preenchendo funções, eles são absolutamente substituíveis. A sensação de que as personagens são quase descartáveis fez com que Henry Longan Stuart, em uma resenha de 1925 sobre Manhattan Transfer, tenha resumido a trama de Ellen em oito breves linhas, argumentando que não estaria fazendo injustiça a Dos Passos, já que não havia qualquer indício de que o próprio autor consideraria aquela trama relevante.

\subsection{A natureza da máquina}

Esse tempo industrial e maquinal é pontuado por elementos que se repõem e se repetem, interrompendo a ideia de simples progressão. No primeiro capítulo, comentamos como, por meio do procedimento da colagem, uma série de fragmentos textuais são rearranjados e ressurgem de formas diferentes ao longo do romance. As canções que viram títulos; os títulos que reaparecem na memória das personagens; ou a epígrafe de abertura do romance, que é reescrita pouco antes do suicídio de Stan. Além disso, há dois elementos que são constantemente retomados: imagens de incêndio e de dilúvio. Se o segundo certamente aparece com uma imagem mítica, o primeiro possui ainda traços históricos, afinal Nova York havia sido vítima de incêndios monumentais ainda no século XIX. Em contraste e complementaridade,

${ }^{405}$ DOS PASSOS, John. O grande capital, cit., p. 72-73. 
ambos são sempre retomados pela narrativa, por um lado, reforçando aquele grupo de materiais que são reconfigurados e reorganizados no romance. Por outro, relacionamse às citações bíblicas nos títulos de alguns capítulos do romance ("One More River to Jordan", "Rejoicing City that Dwelt Carelessly", "The Burthen of Nineveh"). Se a menção às capitais imperiais na epígrafe do segundo capítulo enfatizava, como já foi dito, o aspecto técnico de suas construções (como produto do trabalho humano), nos títulos desses últimos capítulos da terceira parte, não há dúvida de que a referência bíblica impõe uma nova camada de significação. Nesse último bloco, a referência é principalmente Nínive, a cidade que ganhara de Deus uma segunda chance após a profecia de Jonas. Segundo Bart Keunen:

Se no contexto bíblico e em muito da literatura Romântica, Nínive é um símbolo de imoralidade, na obra de Dos Passos a cidade é antes associada à anomia, com o estranhamento do indivíduo em relação ao sistema de valores ${ }^{406}$.

É o contrário, portanto, da análise de David Vanderwerken. Em seu artigo sobre os temas míticos nesse romance de 1925, o crítico argumenta que Manhattan “é a nova Torre de Babel, um templo de palavras falsas, complementada pelas prostitutas do templo. E Ellen, a menina de ouro, é a grande prostituta"407 . A crítica maniqueísta, sem dúvida, não faz jus à complexidade do romance. Já vimos como a construção de Ellen é muito mais profunda e demanda atenção aos detalhes de seu processo de transformação. Da mesma forma, a cidade não é apenas uma moderna Torre de Babel.

Ao não configurar um polo de valores "positivos" (por exemplo, em uma possível figuração do campo), o romance realmente parece associar a imagem de Nínive a um espaço de anomia, mais do que de "imoralidade". Nenhum valor que poderíamos, convencionalmente, opor à ideia de Babel explicita-se nessa narrativa. Observe-se, nesse sentido a trama de Congo: os fragmentos de sua vida, muito difusos e raros, constituem um percurso "positivo", já que no seu caso a ascensão econômica parece cumprir as expectativas. Ainda assim, nada em sua história, um aparente acúmulo de acasos, permite a suposição de ali se configurem, estáveis, valores afirmativos.

É interessante notar como, nesse espaço de anomia, a força do mito produzida pela menção à destruição bíblica da cidade, reforçada pela constante reposição de versos de canções ou de trechos, ao lado das sirenes dos bombeiros e da imagem do

\footnotetext{
${ }^{406}$ [Tradução nossa\} KEUNEN, Bart. The plurality of chronotopes in the modernist city novel: the case of Manhattan Transfer. English Studies: a Journal of Language and Literature, v. 82, n. 5, p. 423, 2001. ${ }^{407}$ VANDERWERKEN, David L. Manhattan Transfer..., cit., p. 265."
} 
dilúvio, gera um efeito cíclico. É como se o tempo imperfeito e as partes autônomas estivessem em uma lógica de reposição, de uma repetição assombrada. Em Manhattan Transfer, disso resulta uma curiosa mistura entre mito e modernidade. O crítico francês George Astre, ao comentar as diferenças entre a abordagem mítica em Ulisses, de James Joyce, e Manhattan Transfer sugere que, enquanto no primeiro a combinação entre "mito" e "história" é capaz de operar uma "síntese", no segundo a justaposição "reforça, ao contrário, a impressão de discordância"408. Essa metrópole seria, então, um estranho híbrido, nebulosa fusão entre máquina e natureza, que se alimenta desses materiais mais mundanos e modernos da produção industrial.

408 “Ce sont, en fait, des implications bibliques qui sous-tendent continuellement la vision de Dos Passos, et la juxtaposition de l'une [implications bibliques] et de l'autre optique [la vision de Dos Passos], loin d'aboutir comme parfois chez Joyce à une prodigieuse synthèse du mythique et du temporel, renforce au contraire l'impression de discordance et de porte-à-faux que l'auteur, au demeurant, ressent très profondément lui-même et veut faire ressentir." ASTRE, Georges-Albert. Thèmes et structures dans l'ouvre de John Dos Passos, cit., p. 151. 


\title{
5. CONSTELAÇÃO PRÉ-FABRICADA: MONTAGEM COMO MOVIMENTO
}

\author{
A story is the day dream of a single man, \\ while history is a mass-invention, \\ the day dream of a race. \\ John Dos Passos ${ }^{409}$
}

Elaborar artisticamente os dilemas de sua época, pensados em chave coletiva, era, para Dos Passos, sua tarefa principal. "The writer who writes straight is the architect of history", escreveria o autor em 1931 sobre o projeto que desenhara para si mesmo. E, para conseguir expressar o universo da metrópole estadunidense, em sua dimensão coletiva, era necessário inventar uma forma. O resultado, essa força autônoma, híbrido de modernidade e mito, é uma expressão complexa do que o progresso técnico representava naqueles anos de euforia. Beatriz Sarlo, escrevendo sobre a modernidade mais periférica de Buenos Aires e a obra de Robert Arlt, observa como

\begin{abstract}
Para los nuevos consumidores, "futurista" era un adjetivo que podía usarse en tempo presente. Su sentido se inclinaba, en general, hacia el optimismo técnico y la magia científica incorporada a la vida cotidiana. Las palabras "avión", "radio", "cine", "transmisión a distancia" organizaban el relato popular de la modernidad. La técnica era un mito expansivo ${ }^{410}$.
\end{abstract}

Tal como se configurou no romance de Dos Passos, a forma da montagem ela mesma um produto do desenvolvimento técnico ${ }^{411}$ - permitiu, por um lado, que se descobrisse os impasses e custos humanos do progresso e, por outro, que se revelasse sua dimensão mítica, sem recair, no entanto, no elogio regressivo de um suposto mundo orgânico.

Analisando a estrutura da trilogia U.S.A., o crítico Robert P. Weeks a aproxima de uma técnica de construção encontrada na poesia de Walt Whitman. Resumindo em linhas gerais o argumento do crítico, a macroestrutura paratática presente na "prosa-poema" de Dos Passos guardaria semelhanças com o paralelismo das poesias de Leaves of Grass. Na poesia de Whitman, a elaboração dessa técnica

\footnotetext{
${ }^{409}$ DOS PASSOS, John. A great American (1927). In: PIZER, Donald (Org.). John Dos Passos: the major nonfictional prose. Detroit: Wayne State University Press, 1988, p. 104.

${ }^{410}$ SARLO, Beatriz. Ciudades y máquinas proféticas, cit., p. 233.

${ }^{411}$ Sergei Eisenstein associa o princípio construtivo da montagem à máquina ao dizer que o termo "descreve o processo de construir" algo a partir de "fragmentos preexistentes". Apud BORDWELL, David. Montage in Theatre and Film. In: PIZER, Donald (Org.). Dos Passos' U.S.A.: a critical study. Charlottesville: University Press of Virginia, 1988, p. 168.
} 
estaria relacionada a uma tentativa de encontrar, literariamente, uma "horizontalidade" a partir da qual fosse possível ordenar o diverso da experiência, sem incorrer em hierarquias, julgamentos ou "deduções lógicas"412. Esse expediente lírico, ainda segundo Weeks, seria também o "elemento mais evidente do estilo de Dos Passos", responsável por organizar todos os níveis da trilogia U.S.A. (a concatenação dos trechos ficcionais, do "Olha da Câmera", dos "Jornais da tela" e também as biografias) e definir o ritmo da leitura. Embora Weeks se refira aos romances de Dos Passos publicados na década de 1930, é impossível, a partir de suas hipóteses, não pensar nos episódios fragmentados de Manhattan Transfer e nas reiterações de imagens e reorganizações de frases, slogans e repetição de versos que constituem a arquitetura da obra. Assim como as personagens da trilogia U.S.A., Ellen, Rosie, James Merivale também parecem percorrer "colunas paralelas", "movidos por forças que eles nem compreendem" e contra as quais não se opõem ${ }^{413}$.

Esse paralelismo estrutural, essa espécie de catálogo elaborado por Whitman, foi interpretado por Eisenstein a partir da análise do poema "The Song of the BroadAx". Como um verdadeiro artista da montagem, argumenta Eisenstein, Whitman multiplica as perspectivas e os elementos que compõem o objeto de seu poema com o fito de extrapolar os limites do conteúdo imediato do que está sendo representado ${ }^{414}$. A fatura seria a produção de uma imagem que se expande para além do que cada item catalogado significa em sua particularidade. No caso de "The Song of the Broad-Ax", o poema parte de um machado factual, como diz Eisenstein, com "m" minúsculo, para alcançar o machado emblema, grafado em letra capital. E é a partir desse paralelismo, definidor também do ritmo dessa justaposição, que o efeito de montagem se configura $^{415}$. No trecho destacado abaixo, o procedimento é evidenciado pelo uso da anáfora.

Where the city stands with the brawniest breed of orators and bards;

Where the city stands that is beloved by these, and loves them in return, and understands them;

Where no monuments exist to heroes, but in the common words and deeds;

Where thrift is in its place, and prudence is in its place;

Where the men and women think lightly of the laws;

\footnotetext{
${ }^{412}$ WEEKS, Robert P. The novel as poem: Whitman's Legacy to Dos Passos. In: PIZER, Donald (Ed.) John Dos Passos's U.S.A.: a documentary volume. Farrington Hills: Gales/Cengage, 2003, p. 141.

${ }^{413}$ WEEKS, Robert P. The novel as poem: Whitman's Legacy to Dos Passos, cit., p. 145.

${ }^{414}$ EISENSTEIN, Sergei. Laocoon. In: Towards a theory of montage. New York: I.B. Tauris, 2010, p. 145.

415 "Whitman scatters fragments of reality right and left by the handful, fragments of nature, of himself, of the globe, of the universe, and they form themselves of their own accord into his gigantic, elemental images." EISENSTEIN, Sergei. Laoocon, cit., p. 163.
} 
Where the slave ceases, and the master of slaves ceases;

Where the populace rise at once against the never-ending audacity of elected persons;

De acordo com Eisenstein, há na poesia de Whitman um procedimento construtivo em que a forma "revela o método" ${ }^{416}$, ou seja, essa estrutura organizada em torno do paralelismo é tornada ainda mais evidente pelo recurso a outros elementos estilísticos como, no caso acima, a anáfora. Todavia, é importante destacar que, ao falar de "paralelismo" na poesia de Whitman, Eisenstein não tem em mente a "montagem de ação paralela ${ }^{417}$. Em "The Song of the Broad-Ax", os fragmentos de um mesmo objeto são dispostos em um encadeamento rítmico como uma "sucessão de itens que dão vida a um mar de associações" ${ }^{\text {418 }}$. O resultado não é a simples soma dos itens dispostos em uma concatenação cadenciada ("factories, arsenals, foundries, markets"). Nesse caso, a estrutura do paralelismo gera, pelo acúmulo, um salto e cria uma imagem "qualitativamente diferente de cada elemento considerado isoladamente". ${ }^{419}$ Por conseguinte, em "The Song of the Broad-Ax", o resultado é algo que extrapola a noção de imagem, ${ }^{420}$ pois trata-se de uma ideia da democracia estadunidense $^{421}$.

Dos Passos também construiu um conceito dessa metrópole, nós já vimos, pela justaposição de fragmentos, pela colisão de figuras míticas, símbolos do consumo, canções populares e histórias (ficcionais e factuais). Seu produto é uma expressão crítica da história do país e da modernização, então ainda em curso, da cidade de Nova York. Há, ainda, algumas outras semelhanças: assim como em Whitman há o desejo de apropriar-se das "palavras" e dos "atos" comuns (apesar do tom grandiloquente do seu estilo declamatório, como se vê nesse poema), Dos Passos

\footnotetext{
${ }^{416}$ EISENSTEIN, Sergei. Laoocon, cit., p. 163.

417 "Montagem de ação paralela" seria a justaposição "de duas linhas de história", como o diretor russo classifica a montagem do cinema de D. W. Griffth, a qual este desenvolveu também a partir da influência dos romances de Charles Dickens. EISENSTEIN, Sergei. A forma do filme. Rio de Janeiro: Jorge Zahar, 2002, p. 183-196.

${ }^{418}$ EISENSTEIN, Sergei. Laoocon, cit., p. 146.

${ }^{419}$ EISENSTEIN, Sergei. O sentido do filme. Rio de Janeiro: Jorge Zahar, 2002, p. 16.

420 "A montagem é uma ideia que nasce da colisão de planos independentes - planos até opostos um ao outro.” EISENSTEIN, Sergei. Dramaturgia da forma do filme. A forma do filme, cit., p. 52.

${ }^{421}$ Não pretendemos apresentar uma interpretação própria desse poema de Walt Whitman. Aqui, estamos apenas seguindo o comentário de Eisenstein com o intuito de expor algumas reflexões do crítico sobre a montagem. Esse trecho do ensaio "Laoocon" nos interessa em especial justamente por tratar da montagem em literatura, mas, acima de tudo, de um poema de Whitman, referência fundamental para a obra de Dos Passos.
} 
também emprega a fala corriqueira, a sonoridade da linguagem urbana e elementos que, além de cotidianos e comezinhos, são mercadorias de massa postas em circulação pela produção em massa, como a música de Tin Pan Alley, as propagandas e as notícias de jornal.

\subsection{Um lance de dados}

Em um artigo de 1987, Christine Poggi observou que, ao introduzir o jornal no plano da pintura, as colagens de Picasso configuravam e absorviam uma experiência que, na época, idealmente deveria ser banida da esfera da arte: a produção em massa. $\mathrm{O}$ expediente adotado pelos cubistas em suas primeiras colagens contrapunha-se, ainda segundo Poggi, a uma faceta corrente da crítica da época que pode ser verificada, por exemplo, em Stéphane Mallarmé. Segundo essa perspectiva, estaria implícita na escrita do poeta, e também muito difundida entre artistas e críticos associados ao movimento simbolista, a noção de que o jornal seria o grande representante de um processo conflituoso para a esfera da arte. Ele consistia na expansão sem precedentes da alfabetização e na forma como o desenvolvimento técnico dos meios de impressão começavam a perturbar certas fronteiras sociais que permitiriam estabelecer uma série de distinções, por exemplo, entre iletrados e letrados, entre detentores da cultura e aqueles que deveriam permanecer fora dela. Como Robert Park observou, há uma correlação entre o crescimento das grandes cidades e a expansão do público leitor e da circulação do jornal, pois o que era "um luxo no campo, tornou-se necessidade na cidade" ${ }^{\text {"422 }}$. Nessa transformação social, o domínio da literatura passou a ser invadido pelos jornais diários, que só na Paris de 1880 já eram mais de setenta, e por meio dos quais floresciam os romances de folhetim $^{423}$. O jornal, com sua justaposição aleatória de materiais mundanos, estaria em imediata oposição ao rigor poético capaz de "disciplinar o acaso" e, nessa medida, representaria um problema à arte.

Indústria de massa, desenvolvimento técnico, justaposição e (aparência de) acaso são todos elementos que, como já sabemos, são parte essencial da própria configuração de Manhattan Transfer. Além de servir como base histórica e indicador

\footnotetext{
${ }^{422}$ PARK, Robert E. The Natural history of the newspaper. The city, cit. p. 81.

${ }^{423}$ POGGI, Christine. Mallarmé, Picasso, and Newspaper as Comodity. In: HOFFMAN, Katherine (Ed.). Collage. A critical view. Michigan: UMI Research Press, 1989, p. 171-192.
} 
cronológico para esse romance de Dos Passos, o jornal e sua desordenação formal ${ }^{424}$, ou seja, a relação meramente contingente de suas partes, influenciaria também a própria estrutura da obra? A fragmentação de Manhattan Transfer seria apenas uma reprodução da lógica aleatória do jornal da qual ele se apropria ${ }^{425}$ - ou, ainda, uma submissão a ela? Delmore Schwartz, editor da Partisan Review, sugeriu uma aproximação similar entre o jornal e a forma do romance em sua resenha de 1938 sobre a trilogia U.S.A.:

If we think for a moment of the newspaper as a representation of American life, we get some idea of the basis of John Dos Passos' enormous novel. (...) It is in its whole sense of American life and its form character - its omnibus, omnivorous span - that Dos Passos' novel seems at least one reader to derive from the newspaper ${ }^{426}$.

Embora o objeto em discussão no trecho acima seja a trilogia, os elementos que o crítico elenca para justificar a afirmação de que a origem do romance seria o jornal - embora mais intensos na trilogia - poderiam ser atribuídos também à Manhattan Transfer: “a sensação das vidas desconhecidas por trás dos anúncios de casamento e obituários, a lacuna imensa entre a vida privada e os eventos públicos" ${ }^{\text {"427 }}$. A fragmentação formal do romance reconheceria, por um lado, nesses artefatos do mundo da cultura de massa o seu significado social, em pé de igualdade com qualquer produto intelectual e artístico; por outro, ao explodir a possibilidade de uma concatenação lógica entre as partes, o romance viveria a reposição do mundo arbitrário, em que os itens não se relacionam e aparecem todos nivelados, exatamente como na lógica do jornal, "plain, sloppy making"428.

É também por esse suposto processo de nivelamento e da ausência de distinção qualitativa entre as partes que Georg Lukács criticou o método da descrição no gênero do romance, tal como se desenvolveu primeiro no Naturalismo. Em obras como as de Zola, mas também em todo o modernismo que, segundo Lukács, derivaria de tendências naturalistas, "a descrição nivela todas as coisas", incapaz de promover,

\footnotetext{
424 “A narração distingue e ordena. A descrição nivela todas as coisas.” LUKÁCS, Georg. Narrar ou descrever?, cit., p. 62.

${ }^{425}$ Discutindo o romance 1919, Sartre tenta compreender certos aspectos do tom narrativo de Dos Passos e argumenta que "Dos Passos reports all his characters' utterances to us in the style of a statement to the Press", indicando a permeabilidade entre o estilo jornalístico e a prosa de Dos Passos. SARTRE, Jean-Paul. John Dos Passos and 1919. (1938). In: MAINE, Barry (Org.). Dos Passos: the critical heritage. New York: Routledge, 1988, p. 172.

${ }^{426}$ SCHWARTZ, Delmore. John Dos Passos and the Whole Truth (1938). In: MAINE, Barry (Org.). Dos Passos: the critical heritage. New York: Routledge, 1988, p. 176.

${ }^{427}$ SCHWARTZ, Delmore. John Dos Passos and the Whole Truth, cit., p. 176.

${ }^{428}$ POGGI, Christine. Mallarmé, Picasso, and Newspaper as Comodity, cit., p. 175.
} 
artisticamente, a "justa distribuição dos pesos" ${ }^{429}$. Em seu ensaio "Narrar ou descrever?", no qual contrapõe ao método narrativo, tal como encontrado no realismo de Balzac ou Tolstói, o "método descritivo" que vemos em Flaubert ou Zola, Lukács menciona Dos Passos e, especificamente, Manhattan Transfer. O romance estadunidense seria, para o crítico, um exemplo significativo do modernismo, um adepto das correntes naturalistas e com o qual partilharia as mesmas fraquezas e distorções. A menção ao livro de Dos Passos não é fortuita, em primeiro lugar, porque representa um desenvolvimento do conhecido debate sobre o Expressionismo dos anos de $1930^{430}$ no qual Dos Passos havia sido mencionado. À escritora Anna Seghers, Lukács chegou mesmo a enfatizar que tratou em seu ensaio da obra de Joyce e Dos Passos unicamente porque Ernst Bloch os havia citado como exemplo anteriormente $^{431}$. Em segundo lugar, é importante lembrar que a obra de Dos Passos era objeto de uma viva discussão também dentro da União Soviética e nas revistas estadunidenses ligadas ao Partido Comunista. Trata-se, está claro, de um debate levado a cabo dez anos após a publicação do romance, quando já eram outras as condições históricas que norteavam a interpretação das obras do período anterior ao crash. A importância dessa discussão, no entanto, reside no fato de ele ter pautado boa parte das interpretações posteriores sobre o que foi produzido nos anos 1920. E embora o debate sobre o Expressionismo dos anos 1930 já esteja bastante difundido entre nós, a discussão sobre Manhattan Transfer e a trilogia na União Soviética e nas revistas literárias estadunidenses nos é menos familiar.

Em um breve "excurso" de seu livro Vom Umgang mit der Moderne, Gudrun Klatt mostra como a produção literária de Dos Passos passou, na União Soviética, por diferentes apreciações antes da avaliação, mais conhecida por nós, de Lukács em “Narrar ou descrever?”. Em março de 1933, foi organizado na União Soviética um encontro de três dias para debater a obra de John Dos Passos ${ }^{432}$. Klatt observa que a discussão sobre a obra de Dos Passos era norteada a partir de duas questões centrais. A primeira lidava com a figura pública de Dos Passos (levando em consideração, por

\footnotetext{
${ }^{429}$ LUKÁCS, Georg. Narrar ou descrever?, cit., p. 61-62.

${ }^{430}$ Sobre o assunto, ver MACHADO, Carlos Eduardo Jordão. Um capítulo da história da modernidade estética: debate sobre o Expressionismo. Ernst Bloch, Hans Eisler, Georg Lukács e Bertolt Brecht. São Paulo: Editora da Unesp, 1998.

${ }^{431}$ LUKÁCS, Georg. LUKÁCS, Georg. Problemas del realismo. Buenos Aires: Fondo de Cultura Económica, 1966, p. 328.

${ }^{432}$ MURPHY, James Francis. The proletarian moment: the controversy over leftism in literature. Chicago; Illinois: University of Illinois Press, 1991, p. 98.
} 
exemplo, seu engajamento no caso Sacco e Vanzetti e sua proximidade ao Partido Comunista) e sua obra literária. A segunda tinha como objetivo examinar o que, na arte ocidental e capitalista, poderia, ou deveria, ser assimilado e absorvido pelos artistas soviéticos na nova fase da "revolução cultural" "333. Entre algumas abordagens da época, Klatt destaca dois críticos que se detiveram com maior interesse sobre a obra de Dos Passos. Dentre esses, o crítico Dmitri Mirski teria rejeitado a tradicional associação entre Joyce e Dos Passos ${ }^{434}$ por não reconhecer neste último um "derrotista" que encontraria um "prazer tortuoso" no mal por ele mesmo desvelado - e seria esse o caso Joyce, segundo Mirski. Embora houvesse semelhanças entre as técnicas de ambos, três aspectos da obra de Dos Passos o tornavam mais relevante e notável aos olhos do crítico. Em primeiro lugar, na obra estadunidense Mirski reconhece uma relação mais intensa e consequente com produtos do presente (o jornal e a propaganda) do que em Ulisses. Em segundo lugar, contava a favor de Dos Passos a expressiva influência dos diretores de cinema soviéticos na técnica literária desenvolvida pelo escritor estadunidense (Mirski tem em mente os dois primeiros volumes da trilogia U.S.A., escritos após o encontro de Dos Passos com Eisenstein). Por fim, a forma de construção de seu romance possibilitaria interpretações diversificadas da realidade capitalista, ou seja, haveria em seu texto uma força de descoberta criativa, o que representaria uma espécie de "libertação da interpretação burguesa" da sociedade ${ }^{435}$. Ainda assim, lamenta Mirski, seria necessário que Dos Passos desenvolvesse seu "talento literário" no sentido de apreender de "forma proletária o que até então ele havia compreendido de forma burguesa"436. Ou seja, seria preciso superar a representação restrita dos destinos individuais, que dominariam a obra toda, para alcançar a representação do verdadeiro movimento histórico coletivo.

Após a publicação da crítica de Mirski, o debate sobre John Dos Passos continuou agitado na União Soviética e sua posição era avaliada ora como sendo a do

\footnotetext{
${ }^{433}$ KLATT, Gudrun. Exkurs 1: Debatten um die "Literatur des Westens" im Umfeld des 1. Allunionskongress der Sowjetschriftsteller - das Beispiel John Dos Passos. In: Vom Umgang mit der Moderne. Ästhetische Konzepte der dreißiger Jahre. Lifschitz, Lukács, Lunatcharski, Bloch, Benjamin. Berlin: Akademie-Verlag, 1985, p. 123.

${ }^{434}$ Mirski estaria debatendo com alguns críticos (especialmente o dramaturgo W. W. Wischnewski) responsáveis por aproximar de tal forma os dois autores, “... que os ouvintes e leitores teriam a impressão de que se trataria de um escritor chamado Joyce-Dos Passos”. KLATT, Gudrun. Exkurs 1, cit., p. 125.

${ }^{435}$ KLATT, Gudrun. Exkurs 1, cit., p. 125.

${ }^{436}$ KLATT, Gudrun. Exkurs 1, cit., p. 126.
} 
criador de um "realismo revolucionário"437, ora como a de um apoiador da luta revolucionária, o chamado "fellow traveler" [Kampfgefährte] - um intelectual simpatizante, mas não realmente engajado e filiado ao Partido Comunista. É, portanto, nesse panorama de indagações acerca da interpretação literária e de modelos para uma “cultura revolucionária” que se insere a crítica de Lukács à obra de Dos Passos. Não nos interessa aqui retomar todo o debate sobre Realismo e Expressionismo desenvolvido pelo crítico húngaro com Adorno, Bertolt Brecht, Benjamin e Bloch um assunto importante, mas já bastante pesquisado e analisado, e que levaria a problemas e conteúdos que fogem a nosso interesse específico. Contudo, é interessante mencionar a crítica de Lukács na medida em que o autor destaca especificamente o romance Manhattan Transfer para indagar acerca dos pressupostos e do resultado dessa forma literária, quando estava em jogo o fortalecimento da Frente Popular.

\subsection{A fellow traveler}

A proximidade que Dos Passos tivera com o movimento comunista nos Estados Unidos e seu engajamento político à esquerda durante as décadas de $1920 \mathrm{e}$ 1930 foi acentuado, bastante produtivo, e era amplamente reconhecido nos Estados Unidos, onde o autor foi rapidamente identificado como um artista e intelectual aliado e, quem sabe, futuro comunista. O jornalista e escritor Michael Gold, membro do Partido Comunista e um dos fundadores da revista New Masses, publicou uma resenha muito entusiasmada em 1926 sobre Manhattan Transfer - a primeira das muitas que escreveria sobre a obra de Dos Passos. Elogiando a sensibilidade do autor para retratar de forma renovada a metrópole que o crítico conhecia como a palma de suas mãos, Gold admite que

eu sempre admirei o maravilhoso escritor John Dos Passos. Ele sempre amou o mundo visível com tal prazer virginal. Seus sentidos são tão frescos; ele fareja como um lobo, vê como uma criança, ouve, degusta e sente com os dedos ${ }^{438}$.

\footnotetext{
${ }^{437}$ KLATT, Gudrun. Exkurs 1, cit., p. 127.

${ }^{438}$ Tradução a partir do original: "I have always admired this gorgeous writer John Dos Passos. He has ever loved his visible world with such virgin delight. His senses are so fresh; he smells like a Wolf, sees like a child, hears, tastes and feels with the fingers."GOLD, Michael. Resenha (1926). In: BARRY, Maine (Org.). Dos Passos. The critical heritage. New York: Routledge, 1988, p. 73.
} 
Apesar dessa avaliação vibrante, Gold já constatava em Dos Passos uma tendência que ele identifica como niilista e que se explicitaria na resistência do autor à filiação ao partido $^{439}$, mas que também seria entrevista na própria obra pelas tramas do romance. Se nos anos de 1920, Dos Passos estava constantemente próximo, mas nunca se filiou realmente ao Partido Comunista (como vimos no segundo capítulo), nos anos de 1930 ele começou um processo gradual de afastamento ${ }^{440}$. Entretanto, pelo menos até 1939, sua reputação junto à esquerda estadunidense era estável e seu distanciamento teve motivos diversos e complementares. Além de divergências que o autor expressou em relação às políticas da Frente Popular nos Estados Unidos, a divulgação dos julgamentos de Moscou e os desdobramentos da Guerra Civil Espanhola fizeram com que, ao fim da década de 1930, Dos Passos rompesse definitivamente com a esquerda que ele apoiara até então.

A primeira sugestão desse afastamento parece ter sido o fato de, ainda em 1932, Dos Passos começar a publicar na revista Common Sense, um periódico independente recém-surgido, e deixar de enviar contribuições para a New Masses ${ }^{441}$. De toda forma, o primeiro desentendimento mais evidente com a esquerda do Partido Comunista ocorreu por ocasião da publicação da "Carta Aberta ao Partido Comunista", escrita em 1934 e assinada por um grupo importante de intelectuais, dentre os quais se encontrava Dos Passos. A carta denunciava a atitude do PC ao perturbar e, por fim, inviabilizar uma reunião aberta organizada pelo Partido Socialista. Embora não fosse uma carta de apoio ao Partido Socialista, ela denunciava a postura dos membros do PC, que "desonravam a causa antifascista"442. O fato de Dos Passos ter assinado a carta gerou um grande desconforto entre os editores do The New Masses, que escreveram um editorial em resposta, justificando a ação do partido e mostrando surpresa pela assinatura de Dos Passos. O texto ressaltava, contudo, que o escritor seguia sendo, como sempre fora, "Dos Passos, the revolutionary writer, the comrade" ${ }^{, 433}$.

\footnotetext{
439 "He must ally himself definitely with the radical army, for in the struggle is the only true escape from middle-class bewilderment today." GOLD, Michael. Resenha (1926), cit., p. 74.

${ }^{440}$ Sobre todo esse período, ver LUDINGTON, Townsend. John Dos Passos, cit., p. 284-400.

${ }^{441}$ LUDINGTON, Townsend. John Dos Passos, cit., p. 310.

${ }^{442}$ AARON, Daniel. The adventures of John Dos Passos. In: Writers on the left: the impact of the idea of communism on American writers - both on those who accepted it and on those who did not. New York: Avon Books, 1969, p. 363.

${ }^{443}$ Apud LUDINGTON, Townsend. John Dos Passos, cit., p. 324.
} 
Se o ceticismo de Dos Passos já começava a crescer, após tomar conhecimento das execuções praticadas pelo governo de Stalin em retaliação ao assassinato de Serguei Kirov, entre 1934 e 1935, o autor perdeu qualquer expectativa positiva em relação ao regime stalinista e o futuro da União Soviética. Sua falta de convicção, todavia, era expressa apenas na esfera pessoal e é hoje conhecida por meio de suas correspondências privadas. Por isso, nesse momento, ele ainda foi convencido por seu amigo Edmund Wilson a participar do primeiro American Writer's Congress, de 1935, largamente organizado pela esquerda comunista. Dos Passos não compareceu pessoalmente, mas enviou por carta um texto que foi publicado junto com a contribuição de outros escritores ${ }^{444}$, muitos dos quais se sentiram incomodados com a argumentação de Dos Passos. Com o título de "The writer as technician", Dos Passos defende, sobretudo, a necessidade de "liberdade" de pensamento para a execução do trabalho de qualquer produtor, inclusive de um artista - nas entrelinhas e de uma forma tortuosa, o texto era uma defesa da independência do escritor em relação a partidos políticos.

A grande ruptura, contudo, ocorreu em 1937, ano em que a última parte da trilogia, The Big Money, foi eleita o melhor romance do ano pelo Second American Writer's Congress. Desde 1936, Dos Passos estava engajado em colaborar com a luta antifranquista na Espanha. Após tentar estabelecer um serviço de informações sobre a guerra civil e procurar convencer o governo estadunidense a vender armas ao governo republicano - e falhar nas duas empreitadas -, Dos Passos idealizou a produção de um documentário para denunciar "o que estava acontecendo aos espanhóis comuns em meio à Guerra Civil" ${ }^{\text {445 }}$.

Após conseguir, ao lado de seu amigo Ernest Hemingway, arrecadar fundos para a realização do documentário, Dos Passos partiu com sua esposa Kathy, Hemingway, Marta Gellhorn, John Ferno e o diretor Joris Ivens para a Espanha. O projeto para The Spanish Earth já começara com uma disputa de concepção entre Hemingway, que pretendia enfatizar as batalhas, e Dos Passos, para quem o foco deveria ser o povo ${ }^{446}$. Um capítulo inteiro poderia ser dedicado aos desdobramentos da produção desse documentário e das disputas que levaram à ruptura decisiva da

\footnotetext{
${ }^{444}$ Embora Dos Passos tenha escrito o texto para que fosse lido durante o congresso, este não chegou a tempo e pôde apenas ser publicado posteriormente.

${ }^{445}$ MORRIS, James McGrath. The ambulance drivers. Hemingway and Dos Passos, a friendship made and lost in war. New York: Da Capo Press, 2017. S/p.

${ }^{446}$ LUDINGTON, Townsend. John Dos Passos, cit., p. 363.
} 
longa amizade entre Hemingway e Dos Passos. Vale destacar que o episódio crucial para Dos Passos foi a descoberta de que seu amigo José Robles ${ }^{447}$, que lutava ao lado do governo republicano na Espanha, fora assassinado por membros do próprio Partido Comunista. Desfeita a relação com Hemingway, que preferia não investigar o assassinato de Robles para evitar problemas com membros do Partido Comunista, Dos Passos retornou aos Estados Unidos ${ }^{448}$ e publicou textos em que opunha o "maquinário sangrento" do Kremlin à luta dos anarquistas e socialistas na Espanha, em detrimento do primeiro ${ }^{449}$. A partir desse momento, sua relação com a esquerda dos Estados Unidos rompeu-se definitivamente. Após esse fato, Michael Gold, que se sensibilizara com a representação da metrópole em Manhattan Transfer e elogiara os três volumes de U.S.A, ao relê-los quando foram publicados em forma de trilogia, argumenta que

[ficou] espantado pela difusão da palavra "merde", sintomática do desgosto de Dos Passos pelo mundo e seu ódio pela humanidade. Como o francês Céline, Dos Passos odeia os comunistas porque organicamente, ele odeia a raça humana ${ }^{450}$.

\subsection{Natureza morta}

“Narrar ou descrever?”, de Lukács, foi escrito em 1936; antes, portanto, da relação de Dos Passos com o Partido Comunista nos Estados Unidos realmente se desgastar, mas quando os desentendimentos políticos entre o escritor e membros do

\footnotetext{
${ }^{447}$ José Robles e Dos Passos se conheceram em 1916, quando Dos Passos visitou, pela primeira vez, a Espanha. Os dois mantiveram uma longa amizade e Dos Passos o visitou algumas vezes quando Robles se tornou professor na Universidade John Hopkins, nos Estados Unidos. Assim que a Guerra Civil eclodiu na Espanha, Robles decidiu ficar em seu país natal e lutar pela causa republicana. Quando Dos Passos chegou a Valência, descobriu, pela esposa de Robles, que seu amigo, na época um funcionário do Ministério da Guerra, estava desaparecido. Sem nenhuma notícia, desesperada e abandonada, a família de Robles pediu a Dos Passos que tentasse descobrir o que acontecera. Hemingway tentou convencê-lo a esquecer o assunto e apenas após muito esforço da parte de Dos Passos, ele foi capaz de descobrir que Robles havia sido assassinado pelo próprio Partido Comunista por motivos muito pouco claros. O episódio todo apenas reforçou a impressão inicial de Dos Passos de que os comunistas "lutavam bem contra os fascistas, mas eles também lutavam contra os sindicalistas, os anarquistas, os socialistas que representavam o grosso dos trabalhadores organizados e contra os liberais de classe média da Catalunha e o País Basco". Apud LUDINGTON, Townsend. John Dos Passos, cit., p. 366.

${ }^{448}$ Vale notar que, após a partida de Dos Passos, o documentário foi concluído sem que houvesse qualquer menção ao idealizador do documentário nos créditos.

449 "In Spain the working class has defend itself with a magnificent heroism that will remain one of the bloodstirring episodes of European history. Meanwhile behind the lines a struggle as violent almost as the war has been going on between the Marxist concept of the Totalitarian State, and the Anarchist concept of individual liberty." DOS PASSOS, John. Farewell to Europe (1937). In: PIZER, Donald (Org.). John Dos Passos: the major nonfictional prose. Detroit: Wayne State University Press, 1988, p. 183 .

450 "Was struck by the pervasiveness of the word 'merde', symptomatic of Dos Passos' disgust with the world and his hatred of humanity. Like the Frenchman Céline, Dos Passos hates communists because organically he hates de human race." GOLD, Michael. Apud AARON, Daniel. The adventures of John Dos Passos, cit., p. 366.
} 
PC já eram de amplo conhecimento. Em seu ensaio, já sabemos, Lukács refutará a possibilidade de associar Dos Passos a uma forma de realismo - o que é consistente, evidentemente, com toda a teoria lukácsiana do romance desenvolvida após 1930. Ao contrário, ele sustenta a aproximação entre Joyce e Dos $\operatorname{Passos}^{451}$ (que havia sido problematizada, como já vimos) e enxerga em ambos a realização do "grau máximo alcançado pelo subjetivismo no romance moderno" ${ }^{\text {452 }}$. Entre os dois escritores, o crítico parece demonstrar uma inclinação mais positiva por Dos Passos, nessa época ainda um "fellow traveler", a quem concede a ressalva de tratar-se de um escritor que "possui um talento incomum" ${ }^{453}$. Apesar disso, a obra de Dos Passos não corresponderia ao tipo de concepção necessária para a elaboração de uma "verdadeira obra de arte". Em Manhattan Transfer, a concepção da obra estaria relacionada, ou mesmo presa, a uma falsa objetividade: atendo-se à superfície, o romance seria incapaz de ordenar a matéria e explicitar para o leitor as articulações sociais, as "conexões objetivas". Quando uma obra "plasma" apenas a "superfície abstrata", a realidade capitalista celebraria "um triunfo literário", mesmo ali onde o autor se considera "politicamente" o adversário mais convicto "do sistema capitalista" $"$ ". Esse seria, portanto, o dilema profundo da obra do bem-intencionado Dos Passos.

O grande problema, e que nos interessa em especial, é o modo como da técnica do romance decorrem a ausência de relação literariamente objetiva entre os destinos humanos e o curso da história, o caráter episódico do texto, a carência de um "autêntico encadeamento dos acontecimentos épicos" - todos esses seriam aspectos que determinariam de antemão a matéria. Nessa medida, o oposto do que Dos Passos afirmava tentar realizar: deixar que a matéria ditasse, por necessidade de expressão, sua forma mais adequada. Ou seja, enquanto Dos Passos afirmava ter arquitetado a forma do romance a partir do embate com a realidade que pretendia representar, Lukács argumentava, ao contrário, que a forma fragmentária da obra de arte moderna determinou, por antecipação, o resultado do tema: em vez de demonstrar o processo de alienação como uma deformação trágica do homem, ela apresenta o homem, de início, como um "morto"455. Nos termos do crítico, quando a forma priva as

\footnotetext{
451 "Este método (...) significa na prática uma tentativa de reduzir todo o desenvolvimento artístico da humanidade ao nível da burguesia decadente: Homero, Shakespeare aparecem como 'produtos' equivalentes a Joyce e John Dos Passos." LUKÁCS, Georg. Narrar ou descrever?, cit., p. 54

${ }^{452}$ LUKÁCS, Georg. Narrar ou descrever?, cit., p. 81.

${ }^{453}$ LUKÁCS, Georg. Narrar ou descrever?, cit., p. 71.

${ }^{454}$ LUKÁCS, Georg. Problemas del realismo, cit., p. 97.

${ }^{455}$ LUKÁCS, Georg. Narrar ou descrever?, cit., p. 83.
} 
personagens de uma "viva humanidade em contínuo desenvolvimento", a "inumanidade do capitalismo" "456 é atenuada. Se, em vez de apresentar as articulações e o dinâmica da força do capitalismo sobre os homens, no romance "modernista", as personagens já são, de antemão, "naturezas mortas", então o destino delas sob o capitalismo perde a proporção de sua real tragicidade.

Como ponto de partida para suas considerações sobre Manhattan Transfer, Lukács cita a crítica entusiasmada de primeira hora de Sinclair Lewis:

Dos Passos possui um talento incomum e Sinclair Lewis é um escritor notável. Por isso mesmo, assume grande interesse a afirmação de Lewis a propósito dos personagens de Dickens e dos personagens de Dos Passos: "É certo que Dos Passos jamais criou e jamais conseguirá criar personagens duradouros como Pickwick (...)".

Esta é uma confissão preciosa, que revela extraordinária sinceridade. ${ }^{457}$

A citação de Lewis é importante no texto porque aproveita o comentário de um grande admirador de Manhattan Transfer para inverter seu sentido: vale-se da observação feita para enfatizar como as personagens construídas por Dos Passos "não estabelecem relações" entre si. No romance o que teríamos são seres humanos e relações pessoais que "aparecem de improviso e de improviso desaparecem" Aliado ao "nivelamento naturalista", do qual Dos Passos seria um continuador, a ausência de riqueza e profundidade das personagens seria correlata a uma concepção que não enxerga a riqueza e a profundidade do próprio "processo social" ${ }^{459}$. Tais as características do romance acarretariam no caráter episódico da estrutura da obra e no “estreitamento esquemático" 460 de suas personagens.

Já vimos como, desde a publicação do romance em 1925, as personagens foram reiteradamente criticadas por sua carência de profundidade. A queixa é justificável, conforme já pudemos demonstrar, e Lukács, portanto, tem razão ao mencionar que, por sua própria constituição, as figuras não são duradouras, não criam um tipo de imagem que as marque na história literária como, por exemplo, Paulo Honório. Além disso, para o crítico, o fato de as correntes do Naturalismo evitarem a

\footnotetext{
${ }^{456}$ LUKÁCS, Georg. Narrar ou descrever?, cit., p. 83.

${ }^{457}$ LUKÁCS, Georg. Narrar ou descrever?, cit., p. 71.

${ }^{458}$ LUKÁCS, Georg. Narrar ou descrever?, cit., p. 70-71.

${ }^{459}$ LUKÁCS, Georg. Problemas del realismo, cit., p. 149.

${ }^{460}$ LUKÁCS, Georg. Narrar ou descrever?, cit., p. 70-71.
} 
representação de momentos de "crise" representaria um falseamento do aspecto trágico que cumpriria à literatura expressar $^{462}$. Lukács cita como exemplo os irmãos Goncourt, os quais julgavam que eram não os grandes momentos de crise, mas sim os "hábitos cotidianos" os mais significativos na representação da vida humana.

Sem dúvida, na construção das tramas de Manhattan Transfer, o aspecto trágico dos grandes momentos críticos da vida de Jimmy ou Ellen são ceifados. Restanos apenas os eventos funestos das trajetórias de Anna, Bud ou Stan que, com tão pouco espaço na narrativa, não são capazes de estabelecer uma relação de identificação entre leitor e personagem. Além disso, ao contrário do que gostaria Lukács, o narrador de Dos Passos intencionalmente não capta, ou não explicita, os nexos íntimos entre os eventos episódicos, entre a ordem social profunda e a superfície dos acontecimentos ${ }^{463}$, e o mundo humano parece dominado pelo mundo das coisas. Essa soberania do mundo material faria com que a coisificação das relações aparecesse em conexão estreita com a "falta" de profundida das personagens. A descrição do crítico é pertinente, mas resta dar o passo interpretativo. Não interessa, a esse projeto, elaborar uma espécie de resposta a Lukács, que conhecia bem os argumentos contrários (mas provavelmente não uma análise profunda da obra de Dos Passos) à sua interpretação e os antecipa quando escreve:

\begin{abstract}
Mas essa nova forma de composição [que é esteticamente inferior à antiga] não é, precisamente, a imagem adequada do capitalismo "feito e acabado"? É verdade que a nova forma geral de composição é inumana e transforma o homem em acessório das coisas, em ser imóvel, elemento estático de uma natureza morta; mas não é exatamente esta transformação operada no homem real pelo capitalismo?

O raciocínio é sugestivo, mas nem por isso deixa de incorrer num equívoco básico. Antes de mais nada, contém lembrar que na sociedade burguesa vive também o proletariado. ${ }^{464}$
\end{abstract}

A posição defendida por Lukács está visceralmente ligada às coordenadas históricas e ao debate nos quais se insere, mas alguns pontos levantados nesse ensaio dão o que pensar. Por isso, o que aqui se segue não é uma tentativa de debater com Lukács, mas de partir dessas questões que, ainda hoje, podem nos fazer refletir sobre

\footnotetext{
${ }^{461}$ Para explicar a importância reveladora dos momentos de crise, Lukács cita Marx, que disse em outro contexto: "a crise revela a unidade dos momentos que estavam reciprocamente isolados". LUKÁCS, Georg. Narrar ou descrever?, cit., p. 56.

462 "A humilhação e a mutilação do homem realizadas pelo capitalismo são mais trágicas, e a bestialidade é mais cruel e mais estúpida do que podem fazer supor as imagens proporcionadas pelos melhores romancistas desse gênero". LUKÁCS, Georg. Narrar ou descrever?, cit., p. 84.

${ }^{463}$ LUKÁCS, Georg. Narrar ou descrever?, cit., p. 90.

${ }^{464}$ LUKÁCS, Georg. Narrar ou descrever?, cit., p. 81.
} 
o alcance da obra do Dos Passos. Ou seja, se o romance critica a forma maquinal da metrópole a partir de uma técnica narrativa (a montagem), ela mesma tributária do desenvolvimento técnico e mesmo semanticamente associada ao mundo maquinal, como analisar seu potencial crítico? Se for verdade que a forma do romance simplesmente repõe a lógica arbitrária do jornal, o ritmo da produção industrial que ela mesmo crítica, então o romance instauraria, na malha da metrópole, um beco sem saída. Por outro lado, se é apenas essa técnica quase mecânica de "desmembrar o realismo" 465 que pode fornecer uma perspectiva crítica sobre a realidade, como interpretá-la?

\subsection{In Advance of The Broken Arm ${ }^{466}$}

Ao escrever, em 1932, a introdução da nova edição de Three soldiers, Dos Passos procura compreender a forma como sua obra expressa o presente, sua e de Joyce, e afirma que seu projeto seria, no fim das contas, um modo de inverter o sentido das forças sociais e "dominar a máquina de produção" 467 . Nesse processo, Dos Passos (novamente, assim como Joyce) toma as mercadorias da produção de massa como algo essencialmente alheio a qualquer noção de singularidade, exatamente como Duchamp havia, originalmente, descrito seus ready-made ${ }^{468}$. A postura do narrador ao apropriar-se desses objetos poderia ser, como observa Lukács, uma "atitude de repórter" 469 que se apropria dos documentos com o intuito inicial de que corroborem sua estrutura previamente formada. Ocorre que a estrutura fragmentária desses pedaços da cidade determina também, nós já vimos, a própria forma da obra, como uma constelação de elementos que se relacionam para a construção de uma ideia que, todavia, não corresponde a uma totalidade com um sentido que reúna as partes em aparência de organicidade. A possibilidade de alcançar a construção de uma totalidade dependeria, para Lukács, de uma dissimulação das técnicas literárias:

A sua ação [do poeta épico] é tanto mais geral e empolgante quanto mais este elemento essencial - o homem e a sua praxis social - aparece, não na forma de um rebuscado produto artificial e virtuosístico, mas como algo que nasceu e

\footnotetext{
${ }^{465}$ BRECHT, Bertolt. Observações sobre um ensaio. In: MACHADO, Carlos Eduardo Jordão. Um capítulo da história da modernidade estética: debate sobre o Expressionismo. Ernst Bloch, Hans Eisler, Georg Lukács e Bertolt Brecht. São Paulo: Editora da Unesp, 1998, p. 256.

466 Título de um ready-made de Duchamp (a pá), de 1915.

${ }^{467}$ DOS PASSOS, John. Introduction to Three soldiers (1932). In: PIZER, Donald (Org.). John Dos Passos: the major nonfictional prose. Detroit: Wayne State University Press, 1988, p. 147.

${ }^{468}$ RICHTER, Hans. Dada. Art and anti-art. Londres: Thames \& Hudson, 1997, p. 90.

${ }^{469}$ LUKÁCS, Georg. Narrar ou descrever?, cit., p. 93.
} 
cresceu naturalmente, quer dizer, como algo que não é inventado e sim, apenas, descoberto. ${ }^{470}$

Esses artifícios artísticos, esses "meios bastante complexos" "471 que o autor deveria disfarçar, são justamente aqueles que Dos Passos pretendem expor, deixando as rupturas claras, os procedimentos (como em Whitman) revelados. Mais do que isso, ao se recusar a elaborar a narrativa por meio de uma dissimulação do artifício, Dos Passos expõe sua arte como produto do trabalho, como um produto montado, onde nada parece fonte "natural" do acaso. Certamente, não queremos dizer que Lukács pretendesse ocultar a forma literária como trabalho: o objetivo da prescrição do crítico húngaro era que a forma artística permitisse a expressão das relações sociais sem que qualquer tipo de artifício comprometesse a percepção dessas articulações como algo intrinsecamente relacionado, uma totalidade que rege as diferentes esferas da vida social:

o verdadeiro conhecimento das forças motrizes do processo social e o reflexo exato, profundo e sem preconceitos da ação deste processo sobre a vida humana, assumem a forma de um movimento: um movimento que representa e esclarece a unidade orgânica $^{472}$.

Dos Passos expõe as fraturas e a fragmentação, revelando o método da montagem, o trabalho de organização que se converte, muitas vezes, na aparência de seu oposto, o acaso. Seu romance permite, portanto, que se reconheçam quais são os mecanismos em ação: histórias justapostas, manchetes reais, propagandas que encontramos pela rua. Sua forma não é a da ocultação. A crítica a esse procedimento poderia alegar que, no método descritivo, do qual derivaria o "formalismo" de Dos Passos, "a conclusão é preestabelecida" ${ }^{473}$. Ou seja, o próprio princípio da montagem e da fragmentação definiria, previamente, as possibilidades do romance. Como o ready-made da pá de Duchamp (1915) anteciparia o braço quebrado.

\footnotetext{
${ }^{470}$ LUKÁCS, Georg. Narrar ou descrever?, cit., p. 61.

${ }^{471}$ LUKÁCS, Georg. Narrar ou descrever?, cit., p. 69.

${ }^{472}$ LUKÁCS, Georg. Narrar ou descrever?, cit., p. 57.

${ }^{473}$ LUKÁCS, Georg. Narrar ou descrever?, cit., p. 91.
} 


\section{5 À deriva}

Tivesse optado, em vez de revelar a fratura, por elaborar uma estrutura narrativa na qual as partes se vinculassem organicamente ao todo, Dos Passos teria produzido o efeito de uma continuidade espaço-temporal e de linearidade causal que reivindicaria conexões entre todas partes do romance ${ }^{474}$ : as partes se pressupõem, dependem umas outras e, portanto, justificam-se. No entanto, tal efeito seria capaz de expressar, por exemplo, o momento de verdade e a intensidade da experiência da simultaneidade? Uma narrativa responsável por "distinguir" e "ordenar", em que se ressaltasse também o encadeamento lógico entre as tramas, e na qual as personagens esféricas e duradouras fossem catalizadoras de todas as partes dispersas do romance, submeteria a matéria de Dos Passos a uma ordem de sentido promovida de antemão. Essa ordem de sentido seria oferecida pela elaboração de nexos significativos e evidentes na esfera da experiência de um indivíduo. Reprimiria, desse modo, a expressão literária da tensão crucial entre o material histórico, que o autor pretendia representar, e a forma do romance.

Em Manhattan Transfer, não há uma síntese definitiva dos fragmentos no sentido de estabelecer uma "relação orgânica entre os homens e os acontecimentos, as relações entre os homens e o mundo exterior, as coisas, as forças naturais e as instituições sociais" ${ }^{475}$. Afinal, nada menos orgânico do que a concatenação brusca e incontrita de episódios, indivíduos e coisas nessa obra de Dos Passos. Ainda assim, o romance coloca todos os componentes (os episódios das biografias, a relação entre elas) em movimento constante ao contrastá-los, a cada nova etapa, com fragmentos diferentes (ora uma narrativa de sucesso, ora um trecho de música, ora uma propaganda). Esse movimento - e o fato de sugerirem a possibilidade de relações indeterminadas - faz com que as partes apontem para uma totalização imperfeita: a construção literária dessa metrópole. Poderíamos dizer que se trata de uma "imagem" da metrópole. Contudo, isso apagaria um problema próprio da forma literária de Manhattan Transfer: a montagem é um resultado da impossibilidade de fixação desse conjunto e, portanto, o que ela constrói é também um conceito, algo que não pode ser "plasmado" como uma totalidade em termos narrativos. A pergunta que daí resulta é: mas o que não poderia ser plasmado imediatamente e por quê?

\footnotetext{
${ }^{474}$ HARVEY, David. Condição pós-moderna, cit., p. 241.

${ }^{475}$ LUKÁCS, Georg. Narrar ou descrever?, cit., p. 58.
} 
O "conceito" literário da metrópole é uma totalização na medida em que nela estão latentes as condições de existência de cada um dos fragmentos; e imperfeita porque sobram arestas, lacunas se multiplicam e partes entram em conflito. A impossibilidade de resolver esse conflito, de lapidar um esquema "circular" (portanto, de criar uma imagem), é um dos elementos que marcam a já comentada ambiguidade do texto. Essa ambiguidade desdobra-se no texto, por exemplo, na tensão entre a aparência de naturalidade e a impressão de artificialidade. Isso quer dizer que, ao mesmo tempo em que há uma expressão de simplicidade e de espontaneidade na forma como se representam as cenas e as personagens, seus encontros e desencontros "naturais" pelas ruas de Manhattan, há também artificialidade em seus mecanismos. A ruptura constante e a concatenação a elementos tão heterogêneos instauram uma desnaturalização do produto ficcional, impedem ao leitor a adoção de uma postura convencional e fazem com que se questione qual o regime de ficção está em jogo. Em nenhum momento o romance permite que a atenção do leitor se dilua nos desenredos das tramas: os cortes bruscos obrigam-no a nos distanciarmos, a cada nova interrupção, daquele universo.

Enfatizando as fissuras, recusando disciplinar seus componentes, e insistindo em expor sua artificialidade, a obra demonstra que o sentido dessa realidade não se oferece de forma imediata. Ao negar o tipo de relação de causa e efeito, onde um elemento da trama pressupõe o outro, Dos Passos explicita uma situação social em que as condições que determinam as possibilidades da experiência não são imediatamente reconhecíveis na unidade da experiência subjetiva. A proposição é abstrata, mas fica mais clara quando a associamos às relações que Fredric Jameson e David Harvey tecem ao analisarem de que modo se articulam as transformações sociais do período histórico do modernismo literário. Segundo Jameson, há uma alteração no nível de integração espacial da vida econômica e financeira dos países capitalistas no fim do século $\mathrm{XIX}^{476}$, cujas consequências geram também um problema artístico para a representação da esfera individual:

But the truth of that experience no longer coincides with the place in which it
takes place. The truth of that limited daily experience of London lies, rather, in
India or Jamaica or Hong Kong; it is bound up with the whole colonial system of
the British Empire that determines the very quality of the individual's subjective
life. Yet those structural coordinates are no longer accessible to immediate lived

\footnotetext{
${ }^{476}$ Para as suas análises, tanto Jameson quanto Harvey se baseiam na análise de Lênin desenvolvida em "O imperialismo, fase superior do capitalismo".
} 
experience and are often not even conceptualizable for most people $\mathrm{e}^{477}$.

Isso quer dizer que a experiência individual, as relações que objetivamente um indivíduo estabelece com os elementos em seu entorno, teria se tornado incapaz de representar os vetores sociais que a determinariam. David Harvey sugere que esse é um dos problemas tematizados em The Octopus, de Frank Norris. Nesse romance, publicado em 1901, os "fazendeiros de trigo da Califórnia precisaram reconhecer" que havia uma estrutura de produção e poder econômico, geograficamente dispersa, mas muito enredada, de forma que as consequências de uma crise em outro país ou numa região distante poderiam afetar imediatamente suas vidas ${ }^{478}$.

Norris é um naturalista e seu romance tematiza essas questões, mas não dá conta de expressar a força de dissociação entre a experiência individual e as condições históricas e sociais daquela mesma existência - condições que a influenciam e, ao mesmo tempo, escapam à sua esfera objetiva. A forma de sua narrativa limita o alcance da representação, pois as forças em oposição estão bem definidas, identificadas com personagens que agem em seu nome. Ou seja, há uma personificação dos vetores sociais que se tornam, portanto, reconhecíveis.

Vinte e quatro anos depois, com a intensificação desses processos, Dos Passos procura uma forma não apenas para tematizar as transformações na vida subjetiva e nas relações pessoais, mas também para expressar um problema artístico: caberia ainda ao romance descobrir uma representação que não se limite a uma exposição de um universo subjetivo apartado de outros? Seria ainda possível um certo projeto épico de plasmar as forças de um período histórico?

Esse problema foi abordado por meio de técnicas e concepções distintas e teve, é claro, outras respostas. Manhattan Transfer mobiliza tal descompasso em sua própria forma. Por um lado, temos o cotidiano banal de uma série de indivíduos característicos dessa metrópole: imigrantes e trabalhadores, atrizes e jornalistas, advogados e políticos. Vemos as suas vidas serem conduzidas e ceifadas pelas ideologias da época: do sucesso, da eficiência e do mérito e toda sorte de conflitos gerados pelas condições objetivas da metrópole - aglomeração, anonimato, velocidade. Os caminhos dessa metrópole permitem que as trajetórias desses indivíduos se cruzem, determina suas ligações, impede desenvolvimentos. Essa forma

\footnotetext{
477 JAMESON, Fredric. Postmodernism, or, the cultural logic of late capitalism. Durham: Duke University Press, 1991. p. 410.

${ }^{478}$ HARVEY, David. Condição pós-moderna, cit., p. 265.
} 
fez com que o crítico Warren Beach não conseguisse reconhecer em Manhattan Transfer nada além de $\operatorname{caos}^{479}$ :

Manhattan Transfer é um retrato do caos moral e social: a técnica narrativa corresponde ao tema. Cada capítulo é um punhado aleatório de incidentes das vidas de diferentes pessoas ou grupos, variando entre quatro e dezesseis, sem qualquer relação a não ser pela época e pelo envolvimento comum no caos de Manhattan. Não há nenhum esforço para marcar transições; cada slide substituiu o anterior sem preparação ou desculpa, mas como algo similar ao tremular dos antigos filmes silenciosos ${ }^{480}$.

A aparência caótica é intencionalmente enfatizada no romance e tratada, inclusive, tematicamente. "The peculiar predominance of luck in human affairs", reflete Joe Haraland, em uma conversa com Jimmy. Em suas lucubrações, o antigo "mago de Wall Street" tentava dar sentido ao seu percurso: de um grande milionário da bolsa de valores que se tornara um miserável vagando pelas ruas de Nova York em busca de uns trocados. Sorte e acaso são os elementos que parecem reger esse universo em que o mundo factual, os dados objetivos imediatamente à sua volta não mais pareciam tecer relações objetivas com a vida de cada indivíduo. Para remediar a sensação de estar à deriva em um mundo sem destino, e dar algum significado à sua trajetória, Harland precisa possuir alguma forma de controle. Sua possibilidade de controle reside na posse de um "objeto mágico", uma gravata que o protegeria e garantiria sua fortuna. Ao sacrificar seu amuleto por uma história afetiva, Harland teria perdido suas chances de sucesso no mercado da bolsa de valores, talvez o universo mais avesso a qualquer forma de controle.

Em Manhattan Transfer, a forma, mais de uma vez, contradiz o tema. Nesse romance, não se trata da reiteração do caos. O romance formula o paradoxo entre a experiência subjetivo à deriva do acaso e uma força que, objetivamente, estrutura essas experiências. E justamente aí reside uma das forças da obra: essa estrutura de combinações antitéticas (entre naturalidade e artificialidade, dispersão e montagem) pede a ação do leitor para reorganizar os materiais apresentados, solicita que ele abandone uma posição meramente contemplativa. Estabelece-se uma dinâmica entre

\footnotetext{
${ }^{479}$ Também Lukács fala em um "caos caleidoscópico”. LUKÁCS, Georg. Narrar ou descrever?, cit., p. 69.

${ }^{480}$ Tradução nossa do original: "Manhattan Transfer a Picture of chaos moral and social; and the narrative technique corresponds to the theme. Each chapter is a loose bundle of incidents from the lives of many different persons or groups, anywhere from four to sixteen in number, completely unrelated save in time and their common involvement in the chaos of Manhattan. There is no effort to mark transitions; each slide replaces de preceding one without preparation or apology, but with something like a flicker of the early silent movies." [Tradução nossa.] BEACH, Joseph Warren. American fiction 1920-1940, cit., p. 43.
} 
um efeito de aleatoriedade, da desconexão das partes, e a solicitação de que se busque, nos meandros do texto, articulações que não necessariamente resolvem, mas iluminam o insulamento das partes e sua dinâmica. Concorre para essa requisição formal do leitor a reposição constante dos materiais pré-formados (das músicas), de certos trechos do romance (por exemplo, da epígrafe de Metropolis) e da simbologia da água, do fogo e de Nínive. Se a forma fosse organizada apenas pela concatenação das tramas autônomas, seria possível sugerir que os fragmentos nada podem comunicar além daquilo que, efetivamente, expressam em seu isolamento.

$\mathrm{Na}$ forma de Manhattan Transfer, contudo, os fatos brutos não bastam. O resultado dessa concatenação não é de mera transparência, como Lukács e outros críticos sugeriram. Dito de outro modo, a montagem em Dos Passos não pretende que os materiais factuais expressem de forma imediata a realidade e nem que de sua simples apropriação resulte um conteúdo crítico. Ao contrário, a reunião dos elementos de fundo mítico, dos ready-mades, das colagens ficcionais e das tramas não gera uma síntese, uma unidade harmônica, mas cria atritos. A ausência de síntese, associada ao tipo de material escolhido - não ao acaso - para compor essa forma instável, faz com que os fatos, os dados documentais, não pareçam "falar por si mesmos".

Esses materiais pretendem explicitar, por um lado, que existe um limite para a representação da realidade a partir da compreensão de uma parte isolada dela. Afinal, por que o romance não escolheu a vida de um indivíduo, em torno do qual todos os outros elementos dispersos se reorganizariam? Porque, conforme disse o próprio Dos Passos, "there was more to the life of a great city than you could cram into any one hero's career" ${ }^{481}$. Tampouco caberia apenas na representação de uma série de vidas interligadas, como vemos no romance vitoriano, em que os laços significativos entre as histórias pessoais explicitariam sentidos a princípio ocultos. Contudo, ao recusar a experiência subjetiva como fonte do nexo de sentido da realidade, o romance não recusa o pensamento e a crítica em favor da mera reprodução da fragmentação. O que se afirma, com a ausência de síntese e a solicitação da participação leitor para o estabelecimento articulações, é uma tensão artística entre o acaso aparente e a necessidade formal, entre caos e ordenação, na qual o leitor é impelido a mobilizar sua imaginação.

${ }^{481}$ DOS PASSOS, John. What Makes a Novelist (1968), cit., p. 274. 
Assim como nos anos 1930 as condições históricas determinaram boa parte das interpretações sobre a obra de Dos Passos, são também elas que hoje permitem avaliar como Manhattan Transfer é capaz de revelar a insuficiência das críticas feitas à sua montagem literária. Lukács credita a falha da obra de Flaubert, por exemplo, ao fato de o escritor confundir "a vida em geral com a vida cotidiana do burguês médio". Ou seja, ao confundir seus "preconceitos" com "fatos objetivos", Flaubert não veria, segundo o crítico, outra saída artística que não fosse o método descritivo, uma somatória de episódios desconexos. A totalidade que o crítico deseja ver configurada, ao contrário, dependeria da percepção de que, na "sociedade burguesa", também vive “o proletariado", como sujeito revolucionário - fato que escaparia a Flaubert. Manhattan Transfer é capaz de mostrar - na forma como constrói uma totalização imperfeita e recusa a síntese - que esse sujeito revolucionário, nas condições históricas de 1920, estava inviabilizado pelas próprias forças que a técnica da montagem colocava em movimento. Dos Passos demonstrou que o processo de modernização, tal como se deu nos Estados Unidos, teve um custo humano que já não contava mais com a janela de possibilidade de transformação revolucionária que Lukács e Gold esperavam. A força do romance de Dos Passos reside no modo como essa configuração é iluminada sem que se naturalize as relações sociais; sem aderir, também, a uma crítica ingênua do progresso. Ao representar a estrutura social como montagem, Dos Passos indica o caráter fabricado tanto da história quanto da ficção. 


\section{CONSIDERAÇÕES FINAIS}

Porque não podes, sozinho, dinamitar a ilha de Manhattan

"Elegia 1938", Carlos Drummond de Andrade

"Nova York era um continente em si mesma", escreveu Dos Passos em seu livro de memórias, registrando a impressão que a cidade lhe causara nos anos 1920 . O assombro e o fascínio despertados pelo crescimento urbano naquelas primeiras décadas do século XX foi um tema caro à literatura da época. Com Manhattan Transfer, Dos Passos foi capaz de conjugar a representação de questões universais sobre a modernização do espaço urbano (comentadas, por exemplo, por Simmel, que escrevia sobre essa experiência no Velho Continente) à formalização e tematização de dilemas específicos da história dessa ex-colônia em vias de se tornar a maior potência mundial.

A ênfase de Dos Passos na construção de uma narrativa objetiva e a recusa do mergulho na subjetividade e da representação do processo histórico como uma vivência individual estão profundamente relacionadas às especificidades da modernização em um país que não tinha as ruínas de uma antiga ordem estabelecida para lamentar. Hawthorne comentou, no prefácio de o Fauno de mármore (1860), como a claridade desanuviada da "prosperidade trivial" impedia o seu trabalho de escritor, que precisaria se nutrir, ao contrário, das ruínas umbrosas do Velho Mundo. Manhattan Transfer enfrenta essa paisagem menos "nobre" do Novo Mundo, tematiza o sentimento de "prosperidade" e expressa a "confiança absoluta" caracterizou esse período, mas da qual ele também dependia. Contrapõe a essa atmosfera luminosa, contudo, o cemitério mecânico, repleto de metais corroídos, da industrialização. A fragmentação em Dos Passos não é ruína, como antinomia de uma suposta totalidade perdida: é a essência de um processo social que definia o espaço e a experiência do tempo e não poderia ser pensada a partir das antíteses mais convencionais. Sem tentar responder aos dilemas e limites desse processo, que só na década seguinte se evidenciariam, o romance indica a sua presença e expõe a sua intrincada relação nos eufóricos anos 1920.

Um pessimismo da forma em oposição a um otimismo reiteradamente enunciado, dissemos na introdução dessa tese. Os movimentos irregulares das forças

${ }^{482}$ FITZGERALD, F. Scott. Ecos da era do jazz, cit., p. 22. 
mecânicas e duras da cidade são explicitados no impacto que causam sobre os inúmeros cacos de vidas espalhados pelo romance. Essa estrutura múltipla foi elogiada por Michael Gold, que a interpretava como uma "visada coletiva" por parte do autor. Ao contrário de Ulisses, no qual haveria apenas "uma consciência torturada do indivíduo burguês", Dos Passos teria construído algo novo. Gold justificou a sua predileção afirmando que o romance estadunidense, por possuir essa perspectiva francamente coletiva, seria capaz de indicar o futuro e expressar qual seria o novo papel da arte nele ${ }^{483}$. A importância conferida pelo crítico a esse aspecto da obra de Dos Passos sem dúvida estava relacionada ao engajamento político do próprio Gold. Por um lado, portanto, para o crítico, o aspecto coletivo de Manhattan Transfer seria uma expressão da luta do proletariado nos anos 1920 - não a história da consciência subjetiva de um homem, mas a dinâmica viva de uma sociedade, o próprio movimento da história. Por outro lado, a ênfase no caráter coletivo de sua obra também terminaria por se revelar fundamental com a esperada concretização da revolução internacional, após a qual a obra de arte deveria necessariamente abandonar a representação solipsista do indivíduo para pensar problemas coletivos a partir de uma perspectiva igualmente ampla. O futuro, no entanto, contrariou Gold nos dois sentidos. Primeiro, porque as décadas seguintes não testemunharam o espraiar da revolução, mas, sim, o fortalecimento dos Estados Unidos como o grande centro do capitalismo mundial. Em segundo lugar, Dos Passos não teve grandes continuadores, e a sua obra, por motivos diversos, foi deixada de lado.

A experimentação formal modernista de Manhattan Transfer revelou os processos históricos de sua época e indicou, sim, um futuro, embora não aquele ansiado pelos críticos. A relação antagônica entre modernismo, experimentação formal e realismo parecia não ter sentido na atmosfera do Novo Mundo, em que o modernista Dos Passos reconhecia principalmente no realista (ou naturalista) Theodore Dreiser o seu grande precursor. Com a sua "descrição verdadeira da vida das pessoas" ${ }^{484}$, abrindo caminho para o naturalismo em um período tomado pela genteel tradition, Dreiser havia franqueado as portas da arte para toda uma geração. O universo que Dos Passos pretendia investigar não era o mesmo “descrito" por Dreiser, e as novas coordenadas dessa metrópole exigiam ser descoberta por novos meios.

\footnotetext{
483 "I envy his achievement rather than that of Joyce's, for Dos Passos leads to the future." GOLD, Michael. The Education of John Dos Passos (1933). In: BARRY, Maine (Org.). Dos Passos. The critical heritage. New York: Routledge, 1988, p. 115.

${ }^{484}$ DOS PASSOS, John. The best times. Nova York: The New American Library, 1966. p. 206.
} 
Nesse sentido, a forma modernista de Manhattan Transfer não pretendeu romper o caminho realista aberto por Sister Carrie, mas elaborar um modo de apreender e compreender, sob uma lente objetiva, a verdadeira vida da "segunda maior metrópole do mundo".

Antonio Candido, analisando as transformações do papel assumido pela literatura no Brasil, observa que, nas condições particulares da ex-colônia, a obra ficcional dos nossos escritores tinha adquirido um "significado de iniciação ao conhecimento da realidade do país". No entanto, pondera Candido, com o avanço da divisão do trabalho e da especialização, por exemplo, além do desenvolvimento da sociologia, a literatura se viu "atacada em campos que haviam sido (...) seus campos preferenciais" ${ }^{485}$, do que decorreu uma espécie de retração de suas ambições.

Quando Dos Passos escreveu Manhattan Transfer, já havia um esforço extensivo por parte da incipiente sociologia urbana estadunidense no sentido de compreender e delimitar os problemas objetivos e as especificidades da nova configuração da grande cidade: os seus cortiços, os tipos sociais característicos dela, a circulação da imprensa. Os estudos de Robert Ezra Park, Ernest Burgess e o grupo da escola de Chicago - os primeiros passos da pesquisa urbana em sociologia nos Estados Unidos - tinham como objetivo desvelar a dimensão dos problemas dessa realidade emergente. Manhattan Transfer não se retraiu frente ao estudo especializado da realidade da metrópole e buscou construir, pela literatura, também uma perspectiva ampla de investigação social e histórica, observando de que modo o papel do indivíduo está enredado nas forças que movimentam o maquinário da metrópole. Desde os seus primeiros romances e escritos não ficcionais, Dos Passos elaborou uma reflexão contínua acerca da relação entre a industrialização e a guerra. Os efeitos dessa intricada associação sobre o conjunto da sociedade comparece, de forma mais complexa, nesse romance escrito em 1925. Nele estão expressas tanto a relação entre a lógica industrial e o campo de batalha quanto uma reflexão sobre o perigo da nova investida imperialista que começava a ganhar força após a vitória de 1918. Ao debruçar-se sobre esses problemas, o autor pôde iluminar os primeiros ímpetos do funcionamento da "great steamroller of American finance", que parecia disposta a "grind down even further the United States and the world" 486.

\footnotetext{
${ }^{485}$ CANDIDO, Antonio. Literatura e cultura de 1900 a 1945, cit., p.142-143.

${ }^{486}$ DOS PASSOS, John. The new masses I'd like (1926). In: PIZER, Donald (Org.). John Dos Passos: the major nonfictional prose. Detroit: Wayne State University Press, 1988, p. 82.
} 
Edmund Wilson manifestou grande apreço pela trilogia U.S.A., mas muitas restrições no que diz respeito a Manhattan Transfer ${ }^{487}$. Mesmo assim, em seu ensaio "Dos Passos and the social revolution", o crítico argumenta que, apesar de todos os problemas presentes tanto em Manhattan Transfer quanto na peça contemporânea Airways Inc., Dos Passos era o único grande escritor de sua geração que empreendeu um "esforço sistemático" para dar conta de um quadro social abrangente. Ainda segundo Wilson:

most of the first-rate men of Dos Passos's age - Hemingway, Wilder, Fitzgerald cultivate their own little corners and do not confront the situation as a whole. Only Dos Passos has tried to take hold of it ${ }^{488}$.

A obra dos escritores dessa geração centrava-se, para o crítico, em experiências históricas restritas a grupos ou indivíduos, sem abranger uma dimensão coletiva - talvez possamos dizer "épica". E nesse conjunto, Manhattan Transfer se destacaria. Sua própria forma, nós já vimos, contrapunha-se intencionalmente a um importante empenho subjetivista crescente nas correntes modernistas de sua época. Em consonância com as obras de seus contemporâneos, Manhattan Transfer se perguntava, justamente, sobre a configuração moderna da relação entre os destinos individuais e o curso da história. Como seria possível ainda esperar que a vivência individual fosse capaz de explicitar os nexos de um processo histórico cujas forças agiriam no sentido de anular essa mesma individualidade? Dos Passos apostou no projeto ambicioso de investigar o universo metropolitano. Manhattan Transfer não oferece respostas, mas reinventa o gênero do romance, sem abrir mão de sua vocação realista, para revelar os impasses da própria formação da subjetividade. Se o que se exigia de seu romance era a representação da totalidade oferecida pelas relações intersubjetivas, Manhattan Transfer já indicava, ao expor que os dados objetivos condicionavam a experiência individual e impediam tanto a subjetivação quando o sentimento de coletividade, o apagamento do horizonte revolucionário. Ao transformar a paisagem urbana em protagonista do romance, desvinculando o sentido do conjunto da obra da experiência subjetiva de uma personagem, Dos Passos mostrou, não o caráter ininteligível daquela época, mas a necessidade de inventar novas formas de pensar o presente.

\footnotetext{
${ }^{487}$ Que podem ser conferidas, por exemplo, na resenha escrito por Wilson para o romance Paralelo 42: WILSON, Edmund. Review (1930), cit., p. 84.

${ }^{488}$ WILSON, Edmund. Dos Passos and the social revolution. In: DABNEY, Lewis M. (Org.).The Edmund Wilson reader. New York: Da Capo Press, 1997, p. 144-145.
} 
Percorrendo os espaços dessa metrópole, Dos Passos mapeou as coordenadas de seu tempo. Por meio de seu experimento literário, improvisado a cada etapa, a forma do romance expôs os aspectos mais contraditórios do progresso. Por um lado, representou a vivência fragmentária e aparentemente aleatória nesse novo universo. Por outro, mostrou o movimento das forças colossais que determinam a lógica que rege esse espaço. A obra de Dos Passos revelou, também, os limites de uma época tanto da sociedade que se construía efetivamente quanto dos projetos políticos imaginados - e reverbera ainda hoje. Embora muitas coordenadas históricas tenham se transformado, a vida nos grandes centros urbanos continua impondo ao sujeito a aparentemente intransponível experiência da fragmentação, do anonimato e da multidão, das imagens da publicidade e do cinema, do automóvel e da velocidade dessas vias, onde as partes se repõem em ritmo frenético e tirânico. Em uma época em que as utopias se viram frustradas e a "felicidade coletiva" parece novamente adiada para o próximo século, o projeto ambicioso de Dos Passos mostra que é possível e necessário inventar novas formas de enfrentar a matéria histórica. 


\section{REFERÊNCIAS}

\section{Obras do autor}

DOS PASSOS, John. A great American (1927). In: PIZER, Donald (Org.). John Dos Passos: the major nonfictional prose. Detroit: Wayne State University Press, 1988.

DOS PASSOS, John. A Humble Protest (1916). In: PIZER, Donald (Org.). John Dos Passos: the major nonfictional prose. Detroit: Wayne State University Press, 1988.

DOS PASSOS, John. America and the Pursuit of Happiness (1920). In: PIZER, Donald (Org.). John Dos Passos: the major nonfictional prose. Detroit: Wayne State University Press, 1988.

DOS PASSOS, John. An interview with John Dos Passos (1968). In: PIZER, Donald (Org.). John Dos Passos: the major nonfictional prose. Detroit: Wayne State University Press, 1988.

DOS PASSOS, John. Contemporary Chronicles (1961). In: PIZER, Donald (Org.). John Dos Passos: the major nonfictional prose. Detroit: Wayne State University Press, 1988.

DOS PASSOS, John. Did the New Playwrights Theatre Fail? (1929). In: PIZER, Donald (Org.). John Dos Passos: the major nonfictional prose. Detroit: Wayne State University Press, 1988.

DOS PASSOS, John. Farewell to Europe (1937). In: PIZER, Donald (Org.). John Dos Passos: the major nonfictional prose. Detroit: Wayne State University Press, 1988.

DOS PASSOS, John. Grosz Comes to America (1936). In: PIZER, Donald (Org.). John Dos Passos: the major nonfictional prose. Detroit: Wayne State University Press, 1988. 
DOS PASSOS, John. Introduction to Three soldier (1932). In: PIZER, Donald (Org.). John Dos Passos: the major nonfictional prose. Detroit: Wayne State University Press, 1988.

DOS PASSOS, John. John Dos Passos - interview by David Sander (1962). In: PIZER, Donald (Org.). John Dos Passos: the major nonfictional prose. Detroit: Wayne State University Press, 1988.

DOS PASSOS, John. Looking back on U.S.A (1959). In: PIZER, Donald (Org.). John Dos Passos: the major nonfictional prose. Detroit: Wayne State University Press, 1988.

DOS PASSOS, John. Manhattan Transfer. New York: First Mariner Books Edition, 2000.

DOS PASSOS, John. O grande capital. São Paulo: Benvirá, 2012.

DOS PASSOS, John. The best times. New York: The New American Library, 1966.

DOS PASSOS, John. The Evangelist and the Volcano. In: PIZER, Donald (Org.). John Dos Passos: the major nonfictional prose. Detroit: Wayne State University Press, 1988.

DOS PASSOS, John. The fourteenth chronicle: letters and diaries of John Dos Passos. Edited by Townsend Ludington. Boston: Gambit, 1973.

DOS PASSOS, John. The new masses I'd like (1926). In: PIZER, Donald (Org.). John Dos Passos: the major nonfictional prose. Detroit: Wayne State University Press, 1988.

DOS PASSOS, John. They Want Ritzy Art. In: PIZER, Donald (Org.). John Dos Passos: the major nonfictional prose. Detroit: Wayne State University Press, 1988. 
DOS PASSOS, John. Three soldiers. New York: Penguin Books, 1997.

DOS PASSOS, John. Translator's Foreword to Panama: or, The Adventures of My Seven Uncles (1931). In: PIZER, Donald (Org.). John Dos Passos: the major nonfictional prose. Detroit: Wayne State University Press, 1988.

DOS PASSOS, John. Travel books \& other writings. New York: The Library of America, 2003.

DOS PASSOS, John. What Makes a Novelist (1968). In: PIZER, Donald (Org.). John Dos Passos: the major nonfictional prose. Detroit: Wayne State University Press, 1988.

\section{Bibliografia geral}

AARON, Daniel. The adventures of John Dos Passos. In: Writers on the left: the impact of the idea of communism on American writers - both on those who accepted it and on those who did not. New York: Avon Books, 1969.

ALTER, Robert. Imagined cities. Urban experience and the language of the novel. New Haven; London: Yale University Press, 2005.

ANDRADE, Oswald. Imprecação a Tristão de Ataíde. In: . Estética e politica.

São Paulo: Globo, 2011.

BÉJA, Alice. Dos Passos and the Sacco-Vanzetti case: a genealogy of politics and fiction. In: ABREU, Maria Zinia Gonçalves; VASCONCELOS, Bernardo Guido (Eds.). John Dos Passos. Biography and critical essays. Newcastle Upon Tyne: Cambridge Scholars Publishing, 2010.

CHANNELL, Anthony. The Small Town in American Realism. In: SMITH, Christopher (Ed.). American realism. San Diego: Greenhaven Press, 2000.

ARAGON, Louis. Le paysan de Paris. Paris: Gallimard, 2007. 
ASTRE, Georges-Albert. Thèmes et structures dans l'ouvre de John Dos Passos. Paris: Letres Modernes, 1956.

BABLET, D. Exposé Introductif. In: BABLET, D. (Org.). Collage et montage au théâtre et dans les autres arts durant les années vingt. Lausanne: La Cité; L'Âge d'Homme, 1978.

BALZAC, Honoré de. La cousine Bette. Paris: Garnier Frères, 1962.

BARCHAS, Janine. Graphic design, print culture, and the eighteenth-century novel. Cambridge: Cambridge University Press, 2003.

BEACH, Joseph Warren. American fiction 1920-1940. New York: The Macmillam Company, 1942.

BENJAMIN, Walter. A crise do romance. Sobre Alexanderplatz, de Döblin. In: . Magia e técnica, arte e política: ensaios sobre literatura e história da cultura. São Paulo: Brasiliense, 1994.

BENJAMIN, Walter. Flâneur. In: . Charles Baudelaire: um lírico no auge do capitalismo. São Paulo: Brasiliense, 2000.

BERNARDIN, Charles W. Dos Passos' Harvard Years. The New England Quarterly, v. 27, n. 1, Mar. 1954.

BILLETER, Erika. Collage et montage dans les arts plastiques. In: BABLET, D. (Org.). Collage et montage au théâtre et dans les autres arts durant les années vingt. Lausanne: La Cité ; L'Âge d'Homme, 1978.

BISHOP, John Peale. Resenha (1921). In: BARRY, Maine (Org.). Dos Passos: the critical heritage. New York: Routledge, 1988.

BORDWELL, David. Montage in Theatre and Film. In: PIZER, Donald (Org.). Dos Passos' U.S.A.: a critical study. Charlottesville: University Press of Virginia, 1988. 
BRADBURY, Malcolm; RULAND, Richard. From puritanism to postmodernism. A history of American literature. New York: Viking, 1991.

BRADBURY, Malcolm; TEMPERLEY, Howard. Introdução. In: BRADBURY, Malcolm; TEMPERLEY, Howard (Eds.). Introdução aos estudos americanos. Rio de Janeiro: Forense-Universitária, 1981.

BRADBURRY, Malcolm. The modern American novel. New York: Oxford University Press, 1992.

BRECHT, Bertolt. Observações sobre um ensaio. In: MACHADO, Carlos Eduardo Jordão. Um capítulo da história da modernidade estética: debate sobre o Expressionismo. Ernst Bloch, Hans Eisler, Georg Lukács e Bertolt Brecht. São Paulo: Editora da Unesp, 1998.

BREVDA, William. How do I get to Broadway. Texas Studies in Literature and Language, v. 38, n. 1, p. 85, Spring 1996.

BROOKS, Van Wyck. Young America. The Seven Arts, New York: The Seven Arts Publishing Co., v. 1, n. 2, 1916.

BOOTH, Wayne. The rhetoric of fiction. Chicago: The University of Chicago Press, 1983.

BURROWS, Edwin G.; WALLACE, Mike. Gotham. A history of New York City to 1898. New York: Oxford University Press, 1999.

CANDIDO, Antonio. Digressão sentimental sobre Oswald de Andrade. In:

Vários escritos. São Paulo: Duas Cidades, 2004.

CANDIDO, Antonio. Literatura e cultura de 1900 e 1945. In: . Literatura e sociedade. São Paulo: Ed. Nacional, 1965. 
CANDIDO, Antonio. A literatura e a formação do homem. In: . Textos de intervenção. Seleção, apresentações e notas de Vinicius Dantas. São Paulo: Duas Cidades; Editora 34, 2002.

CARONE, Modesto. Em busca de um conceito de montagem. Discurso, São Paulo, v. 4, n. 4, p. 187-194, ago. 1973. Disponível em:

$<$ http://www.revistas.usp.br/discurso/article/view/37752>. Acesso em: 11 maio 2016.

CARONE, Modesto. Metáfora e montagem. São Paulo: Ed. Perspectiva, 1974.

CARR, Virginia Spencer. Dos Passos. A life. Evanston: Northwestern University Press, 2004.

CARVER, Craig. The Newspaper and Other Sources of Manhattan Transfer. Studies in American Fiction, v. 3, n. 2, p. 167-179, Autumn 1975. Disponível em:

$<$ https://muse.jhu.edu/article/441271/pdf $>$. Acesso em: 18 jun. 2015.

CASEY, Janet Galligani. Dos Passos and the ideology of the feminine. Cambridge: Cambridge University Press, 1998.

CATHER, Willa. The professor's house. Lincoln: University of Nebraska Press, 2002.

CHAMBERLAIN, John. Review (1939). In: MAINE, Barry (Org.). Dos Passos. The critical heritage. New York: Routledge, 1988.

CLARK, Michael. Dos Passos's early fiction, 1912-1938. Cranbury, NJ: Associated University Presses, 1987.

COHN, Dorrit. Narrated Monologue: Definition of a Fictional Style. Comparative Literature, v. 18, n. 2, p. 97-112, Spring 1966. Disponível em: <http://www.jstor.org/ stable/1770156>. Acesso em: 08 ago. 2016. 
COHN, Dorrit. Narrative Modes for Presenting Consciousness in Fiction. In:

MCKEON, Michael (Ed.). Theory of the novel: a historical approach. Baltimore:

Johns Hopkins University Press, 2000. Part nine: Subjectivity, character, development.

CORN, Wanda. The great American thing: modern art and national identity.

Berkeley; Los Angeles: University of California Press, 1999.

CORTISSOZ, Royal. American artists. New York: C. Scribner's Sons, 1923.

COSTA, Iná Camargo. Panorama do Rio Vermelho: ensaios sobre o teatro americano moderno. São Paulo: Nankin Editorial, 2001.

DAWSON, Coningsby. Insulting the Army (1921). In: BARRY, Maine (Org.). Dos Passos: the critical heritage. New York: Routledge, 1988.

DE VOTO, Bernard. John Dos Passos: Anatomist of Our Time (1936). In: MAINE, Barry (Org.). Dos Passos. The critical heritage. New York: Routledge, 1988.

DENNIS, Richard. Cities in modernity. Representation and productions of metropolitan space, 1840-1930. New York: Cambridge University Press, 2008.

DENTON, Daniel. Prosperity in New York (1670). In: JACKSON, Kenneth; DUNBAR, David (Orgs.). Empire city. New York through the centuries. New York: Columbia University Press, 2002.

DÖBLIN, Alfred. Crise do romance? In: GREGORY, João Alceu. O romance $O$ tigre azul como forma estética do pensamento histórico de Alfred Döblin. 2003. Tese (Doutorado em Literatura Alemã) - Faculdade de Filosofia, Letras e Ciências Humanas da Universidade de São Paulo, São Paulo, 2003.

DÖBLIN, Alfred. "Die Ermordung einer butterblume" und andere Erzählungen. Munique: Deutscher Taschenbuch Verlag, 1980. 
CAILLOIS, Roger. The edge of surrealism: a Roger Caillois reader. Durham: Duke University Press, 2003.

DENNING, Michael. The cultural front: the laboring of American culture in the twentieth century. New York: Verso, 1998.

DOUGLAS, Ann. Terrible honesty. Mongrel Manhattan in the 1920s. New York: Farrar, Straus and Giroux, 1995.

DOW, William. John Dos Passos, Blaise Cendrars, and the "Other" Modernism. Twentieth Century Literature, v. 42, n. 3, p. 407, Autumn 1996. Disponível em: $<\mathrm{http}$ ://www.jstor.org/stable/441770>. Acesso em: $1^{\circ}$ ago. 2015.

DREISER, Theodor. Life, Art and America. The Seven Arts, New York: The Seven Arts Publishing Co., v. 1, n. 4, 1917.

DREISER, Theodore. Sister Carrie. New York: Bantam Classic, 2007.

DUBOIS, Jacques; DUBOIS, Philppe; EDELINE, Francis; KLINKENBERG, JeanMarie; MINGUET, Phillippe. Douze Bribes pour decoller (en 40.000 lignes).

Collages, Revue d'Esthétique, Paris: Union Genérale d'Editions, n. 3-4., 1978.

DÖBLIN, Alfred. Berlin Alexanderplatz. São Paulo: Martins Fontes, 2002.

DU CAMP, Maxime. Paris, ses organes, ses fonctions et sa vie dans la seconde moitié du XIXe siècle. Paris: Hachette, 1875.

ELWOOD, William R. An Interview with Elmer Rice on Expressionism. Educational Theatre Journal, 20th-Century American Theatre Issue, v. 20, n. 1, Mar. 1968.

EMONS, Hans. Montage-collage-musik. Berlim: Verlag für wissenschafliche Literatur, 2009.

EISENSTEIN, Sergei. A forma do filme. Rio de Janeiro: Jorge Zahar, 2002. 
EISENSTEIN, Sergei. Laocoon. In: Towards a theory of montage. New

York: I.B. Tauris, 2010.

EISENSTEIN, Sergei. O sentido do filme. Rio de Janeiro: Jorge Zahar, 2002.

FIORI, José Luís. O poder global dos Estados Unidos: formação, expansão e limites. In: FIORI, José Luís (Ed.). O poder americano. Petrópolis: Vozes, 2004.

FITZGERALD, F. Scott. Ecos da era do jazz. Crack-up. Porto Alegre: M\&PM, 2007.

FRISBY, David. Simmel et le paysage urbain de la modernité. In: FÜZESSÉRY, Stéphane; SIMAY, Philippe (Org.). Le choc de métropole: Simmel, Kracauer, Benjamin. Paris: Éclat, 2008.

GELFANT, Blanche. The American city novel. Norman: University of Oklahoma Press, 1970.

GEYH, Paula. From Cities of Things to Cities of Signs: Urban Spaces and Urban Subjects in Sister Carrie and Manhattan Transfer. Twentieth Century Literature, v. 52, n. 4, Winter 2006.

GUALBERTO VALVERDE, Rebeca. La ciudad enferma: espacio, metáfora y mito en Manhattan Transfer, de John Dos Passos. Ángulo Recto, Revista de estudios sobre la ciudad como espacio plural, v. 3, n. 1, p. 175-194, 2011. Disponível em: $<$ http://www.ucm.es/info/angulo/volumen/Volumen03-1/varia05.htm>. Acesso em: 02 jan. 2017.

GOLD, Michael. The Education of John Dos Passos (1933). In: BARRY, Maine (Org.). Dos Passos. The critical heritage. New York: Routledge, 1988.

GOLD, Michael. Review (1926). In: BARRY, Maine (Org.). Dos Passos. The critical heritage. New York: Routledge, 1988. 
GOODSON, A.C. Manhattan Transfer and the metropolitan subject. Arizona Quarterly: a journal of American literature, culture, and theory, v. 56, n. 1, Spring 2000 .

GRAHAN, Austin. The great American songbook. Musical texts, modernism, \& the value of popular culture. Oxford; New York: Oxford University Press, 2013.

GRAMSCI, Antonio. Americanismo e fordismo. São Paulo: Hedra, 2008.

GRAMSCI, Antonio. Fordism and Americanism. In: FORGACS, David (Org.). The Gramsci reader. Selected Writings 1916-1935. New York: New York University Press. 2000.

GUILBAUT, Serge. How New York stole the idea of modern art: abstract expressionism, freedom, and the Cold War. Chicago; London: The University of Chicago Press, 1985.

HACKETT, Francis. Doughboys. In: BARRY, Maine (Org.). Dos Passos. The critical heritage. New York: Routledge, 1988.

HALL, Norman Shannon. John Dos Passos lies! (1921). In: BARRY, Maine (Org.). Dos Passos. The critical heritage. New York: Routledge, 1988.

HARDING, Desmond. Ulysses and Manhattan Transfer. A poetics of transatlantic modernism. In: . Writing the city: urban visions and literary modernism. New York: Routledge, 2003.

HARVEY, David. Condição pós-moderna. Uma pesquisa sobre as origens da mudança cultural. São Paulo: Loyola, 2000.

HARVEY, David. Os mitos da modernidade: a Paris de Balzac. In: Paris, capital da modernidade. São Paulo: Boitempo, 2015. 
HARVEY, David. How America's power grew. New imperialism. Nova York: Osford University Press, 2003.

HILFER, Anthony Channell. The Small Town in American Realism. In: SMITH, Christopher (Ed.). American realism. San Diego: Greenhaven Press, 2000.

HOMBERGER, Eric. Chicago and New York: two versions of American Modernism. In: BRADBURY, Malcolm; MCFARLANE, James (Eds.). Modernism - 1890-1930. New Jersey: Humanities Press, 1976.

HOMBERGER, Eric. The Age of "Go Ahead” 1825-1860. In: . The historical atlas of New York city. New York: Henry Holt and Company, 2005.

HOOK, Andrew; SEED, David. John Dos Passos. In: SEED, David (Org.). A company to twentieth-century United States fiction. Chischester: Wiley-Blackwell, 2010.

HOWELLS, William Dean. A hazard of new fortunes. New York: The New American Library, 1965.

JAMES, Henry. Collected travel writings: Great Britain and America. New York: Library of America, 1993.

JAMES, Henry. The ambassadors. New York: Oxford University Press, 1998.

JAMESON, Fredric. Postmodernism, or, the cultural logic of late capitalism. Durham: Duke University Press, 1991.

JEHLEN, Myra. The novel and the American middle class. In: BERCOVITCH, Sacvan; JEHLEN, Myre (Eds.). Ideology and classic American literature. Cambridge: Cambridge University Press, 1987.

JOSEPHSON, Matthew. The Great American Billposter. Broom: an international magazine of the arts, v. 3, n. 4, Nov. 1922. 
KAMMEN, Michael. The lively arts. Gilbert Seldes and the transformation of Cultural Criticism in the United States. New York: Oxford University Press, 1996.

KALAIDJIAN, Walter. Introduction. In: KALAIDJIAN, Walter (Ed.). The Cambridge companion to American modernism. Cambridge: Cambridge University Press, 2005.

KENNER, Hugh. The Making of the Modernist Canon. Chicago Review, v. 34, n. 2, Spring 1984.

KEUNEN, Bart. The plurality of chronotopes in the modernist city novel: the case of Manhattan Transfer. English Studies: a Journal of Language and Literature, v. 82, n. $5,2001$.

KIESEL, Helmut. Geschichte der literarische Moderne. Sprache, Ästhetik, Dichtung im zwanzigsten Jahrhundert. Munique: C.H. Beck, 2004.

KLATT, Gudrun. Exkurs 1: Debatten um die "Literatur des Westens" im Umfeld des 1. Allunionskongress der Sowjetschriftsteller - das Beispiel John Dos Passos. In: . Vom Umgang mit der Moderne. Ästhetische Konzepte der dreißiger Jahre.

Lifschitz, Lukács, Lunatcharski, Bloch, Benjamin. Berlin: Akademie-Verlag, 1985.

KORITZ, Amy. Urban Form vs. Human Function in the 1920s: Lewis Mumford and John Dos Passos. American Studies, v. 45, n. 2, Summer 2004.

KRACAUER, Siegfried. From Caligari to Hitler. A psychological history of the German film. New Jersey: Princeton University Press, 1966.

LAWRENCE, D. H. Review (1927). In: MAINE, Barry (Org.). Dos Passos: the critical heritage. New York: Routledge, 1988. 
LEE, Brian; REINDERS, Robert. A perda da inocência: 1880-1914. In: BRADBURY, Malcolm; TEMPERLEY, Howard (Orgs.). Introdução aos estudos americanos. Rio de Janeiro: Forense-Universitária, 1981.

LENA, Alberto. The colors of New York. Racism, historicism and site in F. Scott Fitzgerald's The great Gatsby. In: BOELHOWER, William; SCACCHI, Anna (Eds.). Public space, private lives. Race, gender, class and citizenship in New York. 18901929. Amsterdam: VI University Press, 2004.

LEWIS, Sinclair. Babbitt. Mineola: Dover Thrift Editions, 2003.

LEWIS, Sinclair. Manhattan at last! (1925). MAINE, Barry (Org.). Dos Passos: the critical heritage. New York: Routledge, 1988.

LOWRY, E. D. Manhattan Transfer: Dos Passos' Wasteland. In: HOOK, Andres (Ed.). Dos Passos: a collection of critical essays. New Jersey: Prentice-Hall, Inc., 1974.

LOWRY, E. D. The Lively Art of Manhattan Transfer. PMLA, v. 84, n. 6, p. 1.636, Oct. 1969. Disponível em: <http://www.jstor.org/stable/1261510>. Acesso em: 14 dez. 2014.

LUKÁCS, Georg. Narrar ou descrever? In: . Ensaios sobre literatura. Rio de Janeiro: Civilização Brasileira, 1965.

LUKÁCS, Georg. Problemas del realismo. Buenos Aires: Fondo de Cultura Económica, 1966.

LUDINGTON, Townsend. John Dos Passos: a twentieth century odyssey. New York: E. P. Dutton, 1980.

MACHADO, Carlos Eduardo Jordão. Um capítulo da história da modernidade estética: debate sobre o Expressionismo. Ernst Bloch, Hans Eisler, Georg Lukács e Bertolt Brecht. São Paulo: Editora da Unesp, 1998. 
MAGNY, Claude-Edmonde. Time in Dos Passos. In: HOOK, Andrew (Ed.). Dos Passos: a collection of critical essays. New Jersey: Prentice-Hall, Inc., 1974.

MALOSSI, Gustavo Mor. A construção de sentidos dissidentes de americanismo na revista Seven Arts (1916-1917). 2017. Dissertação (Mestrado em História) - Instituto de Ciências Humanas e Filosofia da Universidade Federal Fluminense, Niterói, 2017.

MARSHALL, Peter; WALKER, Ian. A primeira nova nação. BRADBURY, Malcolm; TEMPERLEY, Howard (Orgs.). Introdução aos estudos americanos. Rio de Janeiro: Forense-Universitária, 1981.

MARTINI, Fritz. Einleitung. Prosa des Expressionismus. Stuttgart: Reclam, 1993.

MARX, Leo. Pastoralism in America. In: CERCOVITCH, Sacvan; JEHLEN, Myra (Eds.). Ideology and classic American literature. New York: Cambridge University Press, 1986.

MCKEON, Michael. (Ed.). Theory of the novel: a historical approach. Baltimore: Johns Hopkins University Press, 2000. Part nine: Subjectivity, character, development.

MCLUHAN, Herbert Marshall. Dos Passos: technique vs. sensibility. In: HOOK Andrew (Org.). Dos Passos: a collection of critical essays. New Jersey: Prentice-Hall, 1974.

MERLEAU-PONTY, Maurice. Cézanne's doubt. In: TOADVINE, Ted; LAWLOR, Leonard (Eds.). The Merleau-Ponty reader. Evanston: Northwestern University Press, 2007.

MORE, Paul Elmer. Modern Currents (from The demon of the absolute, 1928). In: MAINE, Barry (Org.). Dos Passos: the critical heritage. New York: Routledge, 1988.

MOREL, Jean Pierre. Collage, Montage et Roman chez Döblin et Dos Passos.

Collages, Revue d'Esthétique, Paris: Union Générale d'Éditions, n. 3-4, 1978. 
MOREL, Jean-Pierre. John Dos Passos: Manhattan Transfer. Paris: Presses Universitaires de France, 1990.

MOREL, Jean-Pierre. Montage et collage et discours romanesque dans les années vingt et trente. In: BABLET, Denis (Org.). Collage et montage au théâtre et dans les autres arts durant les anees vingt. Lausanne: La Cité; L'Âge d'Homme, 1978.

MORETTI, Franco. O século sério. In: MORETTI, Franco (Org.). A cultura do romance. São Paulo: Cosac Naify, 2009.

MORRIS, James McGrath. The ambulance drivers. Hemingway and Dos Passos, a friendship made and lost in war. New York: Da Capo Press, 2017.

MORRISON, Mark. Nationalism and the Modern American Canon. In: KALAIDJIAN, Walter (Ed.). The Cambridge companion to American modernism. Cambridge: Cambridge University Press, 2005.

MURPHY, James Francis. The proletarian moment: the controversy over leftism in literature. Chicago; Illinois: University of Illinois Press, 1991.

NANNEY, Lisa. John Dos Passos. New York: Twayne Publishers, 1998.

NORRIS, Frank. A plea for Romantic Fiction. In: PIZER, Donald (Ed.). Documents of American realism and naturalism. Carbondale; Edwardsville: Southern Illinois University Press, 1998.

NORRIS, Frank. McTeague. A story of San Francisco. In: Novels and essays. Nova York: The Library of America

NORTH, Michael. Transatlantic transfer: little magazines and Euro-American Modernism. The Modernist Atlantic Conference, De Montfort University, p. 18, July 2007. Disponível em: <http://www.modmags.dmu.ac.uk/file/north_transatlantic_ transfer.pdf $>$. Acesso em: 04 jun. 2016. 
NORTH, Michael. Reading 1922. A return to the scene of the modern. New York:

Oxford University Press, 1999.

NORTH, Michael. Visual Culture. In: KALAIDJIAN, Walter (Ed.). The Cambridge companion to American modernism. Cambridge: Cambridge University Press, 2005.

NOVERR, Douglas A.; STACY, Jackson. Introduction. In: NOVERR, Douglas A.; STACY, Jackson (Eds.). Walt Whitman's selected journalism. Iowa: University of Iowa Press, 2015.

OATS, Joyce Carol. Imaginary Cities: America. In: JAYE, Michael; WATTS, Ann Chalmers (Eds.). Literature and the urban experience. New Jersey: Rutgers University Press, 1976.

OPPENHEIM, James. Editorial. The Seven Arts, New York: The Seven Arts Publishing Co., v. 1, n. 1, 1916.

PARK, Robert. Human behavior in Urban Environment. In: BURGESS, Ernest W.; MCKENZIE, Jean-Pierre; PARK, Robert; DUNCAN, Roderick (Eds.). The city. Chicago: The University of Chicago Press, 1967.

PARK, Robert E. The City: Suggestions for the Investigation of Human Behavior in the City Environment. American Journal of Sociology, v. 20, n. 5, Mar., 1915.

PEASE, Donald. Psychoanalyzing the Narrative Logics of Naturalism: "The Call of the Wild". Journal of Modern Literature, Global Freud: Psychoanalytic Cultures and Classic Modernism, v. 25, n. 3-4, Summer, 2002.

PERLOFF, Marjorie. The avant-garde phase of American Modernism. In: KALAIDJIAN, Walter (Ed.). The Cambridge companion to American modernism. Cambridge: Cambridge University Press, 2005.

PERLOFF, Marjorie. The futurist moment: avant-garde, avant guerre, and the language of rupture. Chicago: University of Chicago Press, 2003. 
PIZER, Donald (Org.). John Dos Passos's U.S.A.: a documentary volume. Farrington Hills: Gales Cengage, 2003.

PIZER, Donald. Toward a modernist style: John Dos Passos. New York: Bloomsbury Academic, 2013.

POGGI, Christine. Mallarmé, Picasso, and Newspaper as Comodity. In: HOFFMAN, Katherine (Ed.). Collage. A critical view. Michigan: UMI Research Press, 1989.

POLYCHRONIOU, Chronis. Rise and Fall of US Imperialism. Economic and Political Weekly, v. 30, n. 30, 1995. Disponível em: <www.jstor.org/stable/4403046>. Acesso em: 11 set. 2016.

POUND, Ezra. Ezra Pound to Henry Ware Eliot, 28 June 1915. In: ELIOT, Valerie; HAUGHTON, Hugh (Eds.). The letters of T. S. Eliot. New Haven: Yale University, 2011. v. 1 - 1898-1922.

RICHTER, Hans. Dada. Art and anti-art. Londres: Thames \& Hudson, 1997.

ROLLAND, Romain. America and the Arts. The Seven Arts, New York: The Seven Arts Publishing Co., v. 1, n. 1, 1916.

ROSENFELD, Anatol. A confusão de Babel: Alfred Döblin. In: . Letras germânicas. São Paulo: Perspectiva, 1992.

ROSENFELD, Paul. The American Composer. The Seven Arts, New York: The Seven Arts Publishing Co., v. 1, n. 1, 1916.

SANDERS, Emmy Veronica. America invades Europe. Broom: an international magazine of the arts, v. 1, n. 1, Nov. 1921.

SARLO, Beatriz. Ciudades y máquinas proféticas. In: Escritos sobre literatura argentina. Villa Ballester: Siglo Vientiuno Editores, 2007. 
SARTRE, Jean-Paul. John Dos Passos and 1919. (1938). In: MAINE, Barry (Org.). Dos Passos: the critical heritage. New York: Routledge, 1988.

SCHLESINGER, Arthur Meier. The rise of the city - 1878-1898. New York: The Macmillam Company, 1969.

SCHWARTZ, Delmore. John Dos Passos and the Whole Truth. (1938). In: MAINE, Barry (Org.). Dos Passos: the critical heritage. New York: Routledge, 1988.

SCOBEY, David. M. Empire city: the making and meaning of the New York city landscape. Philadelphia: Temple University Press, 2002.

SEED, David. Cinematic fictions. Liverpool: Liverpool University Press, 2009.

SELDES, Gilbert. The seven lively arts. New York: Harper and Brothers, 1924.

SHI, David E. Facing facts. Realism in American thought and culture - 1850-1920. New York: Oxford University Press, 2005.

SIMMEL, Georg. As grandes cidades e a vida do espírito (1903). Mana, Rio de Janeiro, v. 11, n. 2, p. 577-591, Oct. 2005. Disponível em:

$<$ http://www.scielo.br/scielo.php?script=sci_arttext\&pid=S0104-

$93132005000200010 \& \operatorname{lng}=\mathrm{en} \& \mathrm{nrm}=$ iso $>$. Acesso em: $1^{\mathrm{o}}$ set. 2016.

SINCLAIR, Upton. Review (1930). MAINE, Barry (Org.). Dos Passos: the critical heritage. New York: Routledge, 1988.

SLADE, Giles. Made to break: technology and obsolescence in America. Cambridge: Harvard University Press, 2006.

SMITH, Christopher (Org.). American realism. San Diego: Greenhaven Press, 2000. 
SOLER, Aline Shaaban. A metrópole e a prosa cinematográfica no modernismo estadunidense: Uma abordagem de Manhattan Transfer, de John Dos Passos. 2015. Dissertação (Mestrado em Estudos Literários) - Universidade Estadual Paulista Júlio de Mesquita Filho, Faculdade de Ciências e Letras, Araraquara, 2015.

STEIN, Gertrude. The autobiography of Alice B. Toklas. In: VECHTEN, Carl Van. (Org.). Selected writings of Gertrude Stein. New York: The Modern Library, 1962.

STUART, Henry Longan. Review (1925). MAINE, Barry (Org.). Dos Passos: the critical heritage. New York: Routledge, 1988.

SPINDLER, Michael. John Dos Passos and the Visual Arts. Journal of American Studies, v. 15, n. 3, Dec. 1981.

TALLACK, Douglas. New York sighs. Visualizing old and new New York. New York: Berg, 2005.

TAVARES, Maria Conceição; BELLUZO, Luiz Gonzaga. A mundialização do capital e a expansão do poder americano. In: FIORI, José Luís (Ed.). O poder americano. Petrópolis: Vozes, 2004.

TICHI, Cecelia. Shifting gears. Technology, literature, culture in modernist America. Chapel Hill; London: The University of North Carolina Press, 1987.

TIERNEY, John. Brooklyn could have been a contender. In: Empire city.

New York through the centuries. New York: Columbia University Press, 2002.

TROMBOLD, John. Popular Songs as Revolutionary Culture in John Dos Passos' U.S.A. and Other Early Works. Journal of Modern Literature, v. 19, n. 2, Autumn, 1995.

TUCHOLSKY, Kurt. John Dos Passos, Manhattan Transfer (1928). Disponível em: $<$ http://www.textlog.de/tucholsky-passos-manhattan.html $>$. Acesso em: 14 maio 2017. 
VALGEMAE, Mardi. Expressionism in the American theater. In: WEISSTEIN, Ulrich (Ed.). Expressionism as an international literary phenomenon: twenty-one essays and a bibliography. Philadelphia: John Benjamins Publishing Company, 1973.

VANDERWERKEN, David L. Manhattan Transfer: Dos Passos' Babel Story. American Literature, v. 49, n. 2, May 1977.

VARELA, Ângela. John Dos Passos' Art: New York's Flashes in Manhattan Transfer. In: ABREU, Maria Zinia Gonçalves; VASCONCELOS, Bernardo Guido (Eds.). John Dos Passos. Biography and critical essays. Newcastle Upon Tyne: Cambridge Scholars Publishing, 2010.

KLOTZ, Volker. Die erzählte Stadt. Ein Sujet als Herausforderung des Romans von Lesag bis Döblin. München: Carl Hanser Verlag, 1969.

WAGNER, Linda. Dos Passos. Artists as American. Austin: University of Texas Press, 1979.

WATT, Ian. A ascensão do romance. São Paulo: Companhia das Letras, 1990.

WEEKS, Robert P. The novel as poem: Whitman's Legacy to Dos Passos. In: PIZER, Donald (Ed.) John Dos Passos's U.S.A.: a documentary volume. Farrington Hills: Gales/Cengage, 2003.

WEISSTEIN, Ulrich (Ed.). Expressionism as an international literary phenomenon: twenty-one essays and a bibliography. Filadélfia: John Benjamins Publishing Company, 1973.

WINEAPPLE, Brenda. Genêt: a biography of Janet Flanner. Lincoln: University of Nebraska Press, 1989.

WHITTAKER, James. Musik or Music? The Little Review, Literature Drama Music Art, Chicago: Margaret C. Anderson, v. 2, n. 2, 1915. 
WHITE, Lucia; WHITE, Morton. The intellectual versus the city. From Thomas Jefferson to Frank Lloyd Wright. Cambridge; Massachusetts: Harvard University Press, 1962.

WHITMAN, Walt. Complete poetry and collected prose. New York: Literary Classics of the United States, 1982.

WILLIAMS, Raymond. O campo e a cidade: na história e na literatura. São Paulo: Companhia das Letras, 2001.

WILSON, Edmund. Dos Passos and the social revolution. In: DABNEY, Lewis M. (Org.).The Edmund Wilson reader. Nova York: Da Capo Press, 1997.

WILSON, Edmund. Review (1930). In: MAINE, Barry (Ed.). Dos Passos: the critical heritage. New York: Routledge, 1988.

WOOLF, Virginia. Mrs. Dalloway. Oxford: Oxford University Press, 2009.

WRENN, John H. John Dos Passos. Rio de Janeiro: Editora Lidador, 1966.

ZINN, Howard. A people's history of the United States: 1492-present. Londres, New York: Routledge, 2003.

ZOLA, Émile. Do romance. São Paulo: Editora Imaginário; Edusp, 1995. 